U.S. Department of the Interior

U.S. Geological Survey

\title{
A Summary Report of Sediment Processes \\ in Chesapeake Bay and Watershed
}

Water-Resources Investigations Report 03-4123

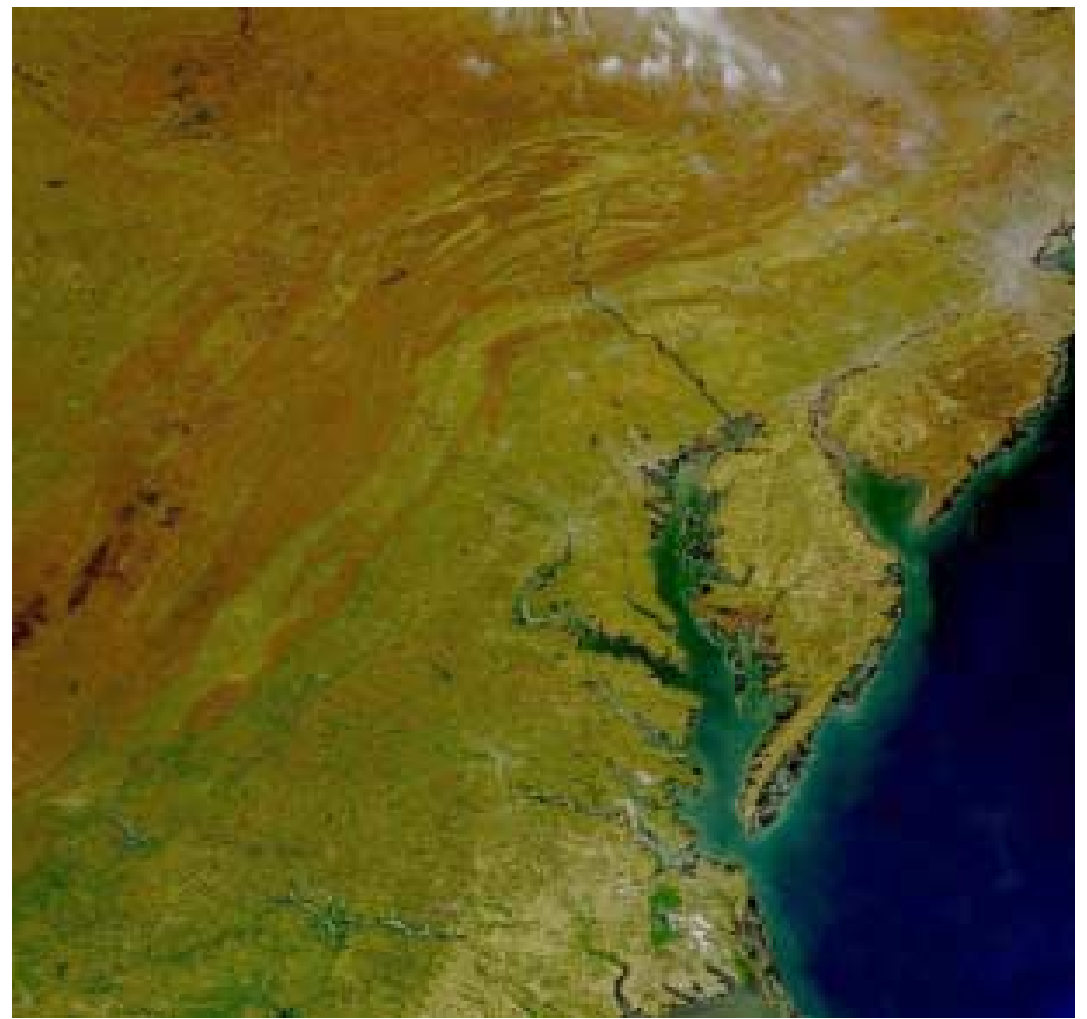


Cover. Image provided by ORBIMAGE. @ Orbital Imaging Corporation and processing by NASA Goddard Space Flight Center. 


\section{A Summary Report of Sediment Processes in Chesapeake Bay and Watershed}

edited by Michael Langland and Thomas Cronin

Water-Resources Investigations Report 03-4123 


\section{U.S. DEPARTMENT OF THE INTERIOR \\ GALE A. NORTON, Secretary}

\section{U.S. GEOLOGICAL SURVEY}

Charles G. Groat, Director

Any use of trade, product, or firm names is for descriptive purposes only and does not imply endorsement by the U.S. Government.

For additional information write to:

\section{District Chief}

U.S. Geological Survey

215 Limekiln Road

New Cumberland, Pennsylvania 17070

Email: dc_pa@usgs.gov
Copies of this report may be purchased from:

U.S. Geological Survey Branch of Information Services

Box 25286, Federal Center

Denver, Colorado 80225-0286

Telephone 1-888-ASK-USGS 


\section{CONTENTS}

Executive summary, by Michael Langland, Thomas Cronin, and Scott Phillips $\ldots \ldots \ldots \ldots \ldots \ldots \ldots . \ldots \ldots$

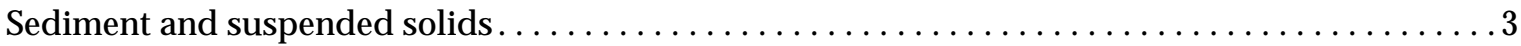

Suspended sediment, water clarity, and submerged aquatic vegetation $\ldots \ldots \ldots \ldots \ldots \ldots \ldots 4$

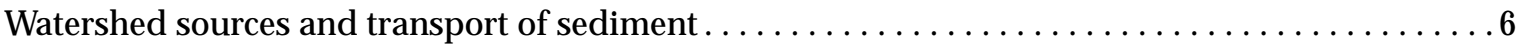

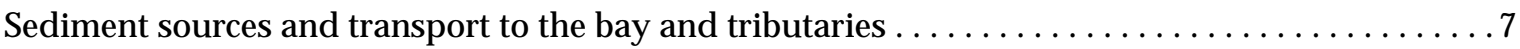

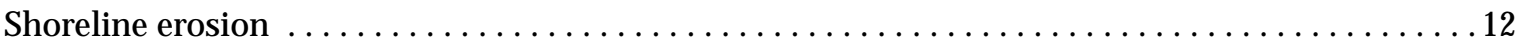

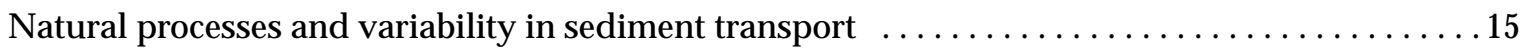

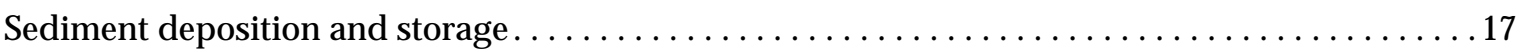

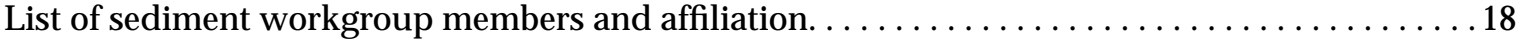

Workgroup members . . . . . . . . . . . . . . . . . . . . . . . . . . . .

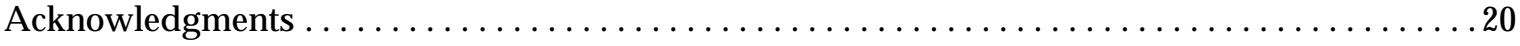

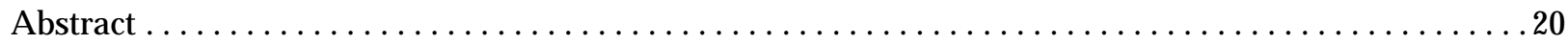

Chapter 1. Introduction, by Thomas Cronin and Michael Langland ......................... 21

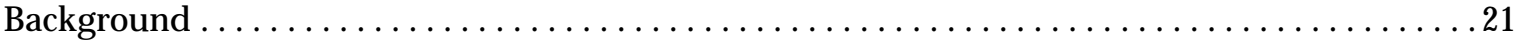

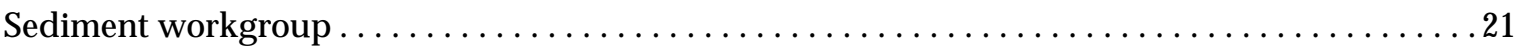

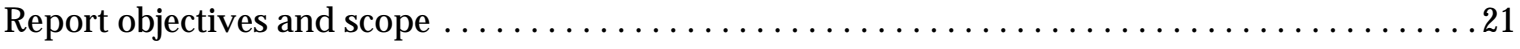

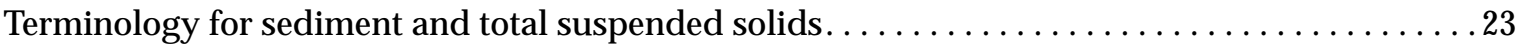

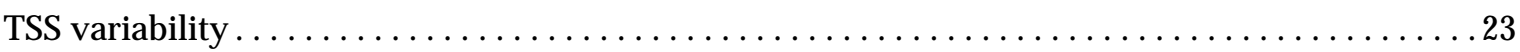

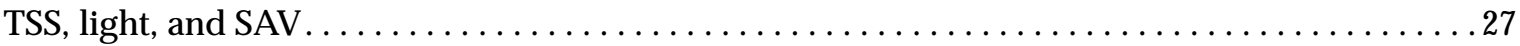

Chapter 2. Watershed sediment sources, by Allen Gellis, Sean Smith, and Steven Stewart ............. 29

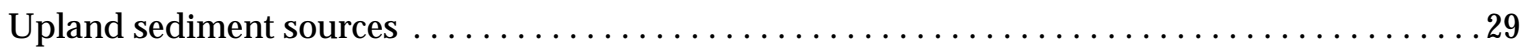

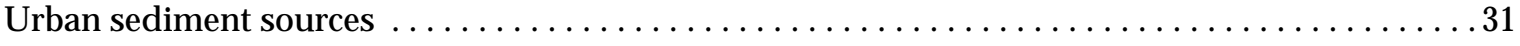

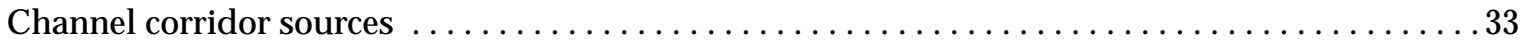

Chapter 3. Watershed sediment transport, by Sean Smith, Michael Langland, and Robert Edwards ........34

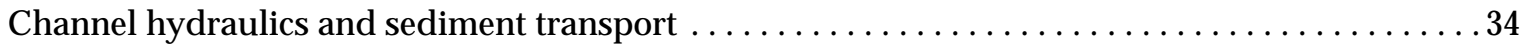

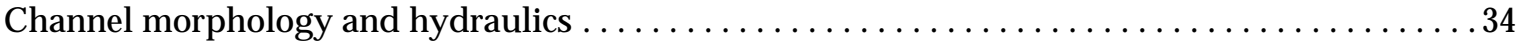

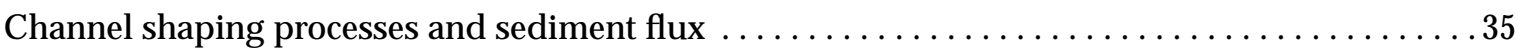

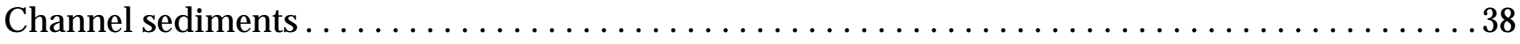

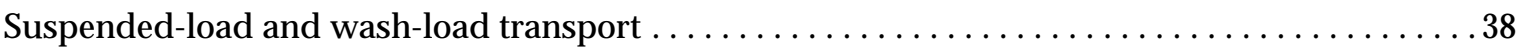

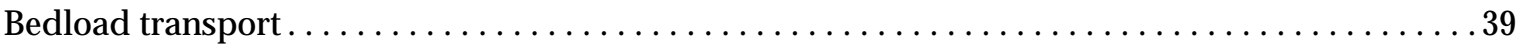

Reach-specific sediment-transport characteristics............................ 40

Chapter 4. Watershed sediment deposition and storage, by Julie Herman, Clifford Hupp, and

Michael Langland ................................................... 42

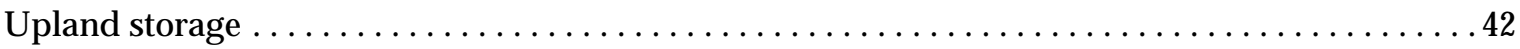

Floodplain and banks............................................. 43

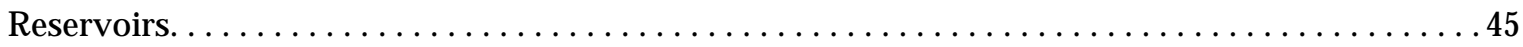

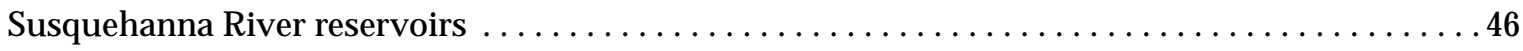




\section{CONTENTS-Continued}

Chapter 5. Estuarine sediment sources, by Thomas Cronin, Jeffrey Halka, Scott Phillips,

and Owen Bricker . . . . . . . . . . . . . . . . . . . . . . . . . . . . . . . . . . . . . 49

Estimates of major sediment sources.................................. 49

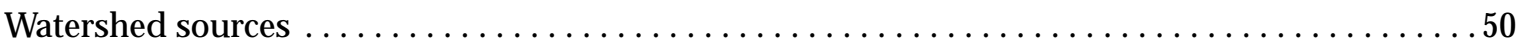

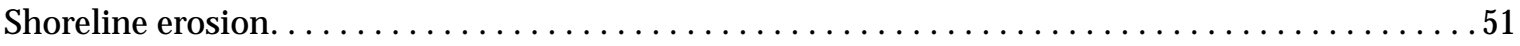

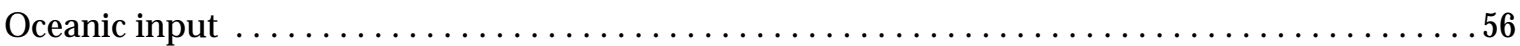

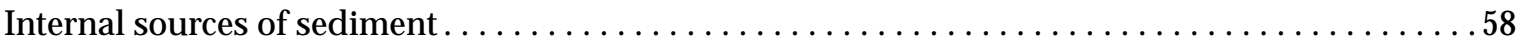

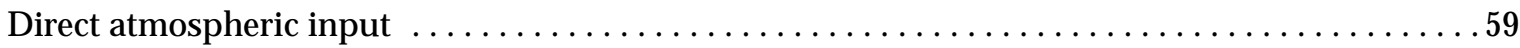

Chapter 6. Estuarine sediment transport, deposition, and sedimentation, by Thomas Cronin,

Lawrence Sanford, Michael Langland, Debra Willard, and Casey Saenger.....................61

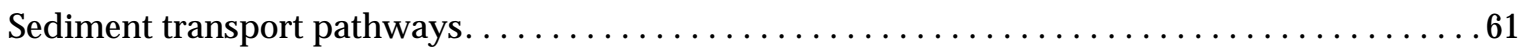

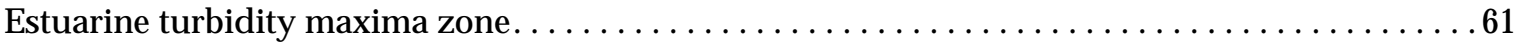

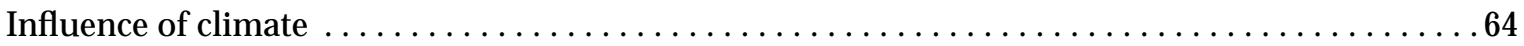

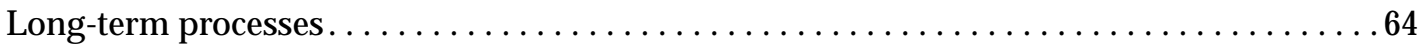

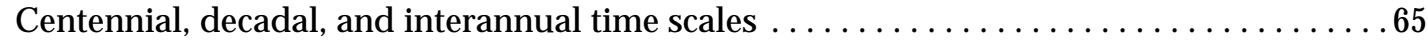

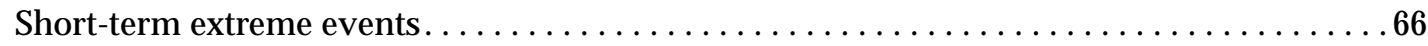

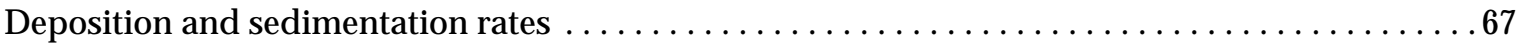

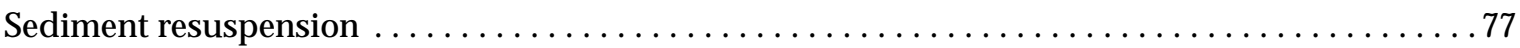

Chapter 7. Integrated approaches to sediment studies, by Sean Smith, Julie Herman,

Thomas Cronin, Gregory Schwarz, Michael Langland, Kenn Patison, and Lewis Linker. .............. 80

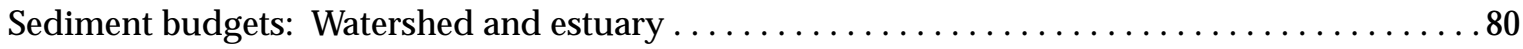

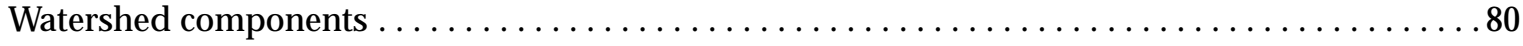

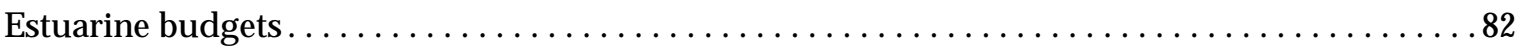

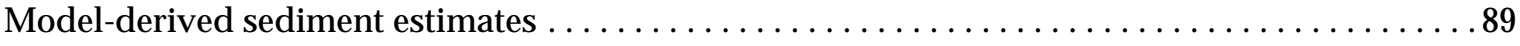

Spatially Referenced Regression Model (SPARROW) for Sediment . . . . . . . . . . . . 89

Chesapeake Bay Watershed Model (WSM) . . . . . . . . . . . . . . . . . . . . 91

Chesapeake Bay Water Quality Model (WQM) . . . . . . . . . . . . . . . . . . . . 93

Sediment reduction controls (best-management practices) $\ldots \ldots \ldots \ldots \ldots \ldots \ldots \ldots \ldots \ldots \ldots$

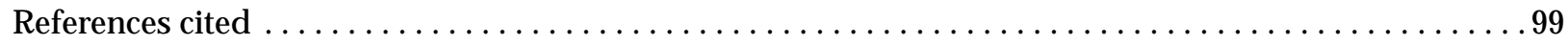




\section{FIGURES}

Page

Executive Summary

Figures 1-4. Maps showing:

1. Location of Chesapeake Bay watershed and estuary $\ldots \ldots \ldots \ldots \ldots \ldots \ldots$

2. Concentrations of total suspended solids in winter and spring, 1992

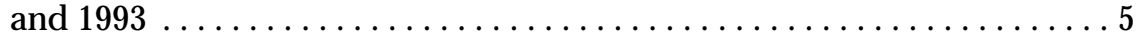

3. Comparison of historical (1880-present) and long-term sediment flux at core sites in Chesapeake Bay . . . . . . . . . . . . . . . . 8

4. Major pathways of sediment transport in Chesapeake Bay ............. 9

5. Pie charts showing relative contributions of sediment sources to the estuary with fastland (above tidal water) erosion and with fastland and nearshore (below tidal

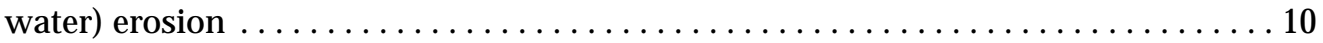

6. Graph showing sources of fine-grained sediment from different sources based on literature (right half) compared to model-generated loads (left half) . . . . . . . . . 11

7. Map showing vulnerability of low-lying regions around Chesapeake Bay to future

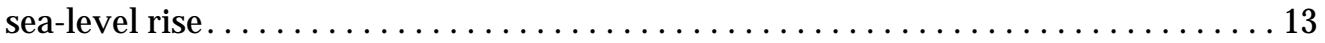

8. Graph showing comparison of coarse- (sand, gravel) and fine-grained (silt, clay) components of shoreline sediments from different studies . . . . . . . . . . . . 14

9. X-radiograph of 400-cm long sediment core from central Chesapeake Bay off Little Choptank River mouth, approximately $11 \mathrm{~m}$ water depth ............... 16

Chapter 1.

1.1. Map showing location of Chesapeake Bay watershed and estuary $\ldots \ldots \ldots \ldots \ldots 22$

1.2. Graph showing mean monthly concentrations of total suspended solids (TSS) at two CBP monitoring sites for shallow $(0.5 \mathrm{~m})$, near-surface $(2-4 \mathrm{~m})$, and

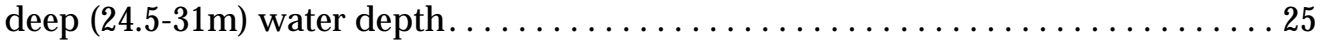

1.3. Map showing concentrations of total suspended solids in winter and spring, 1992

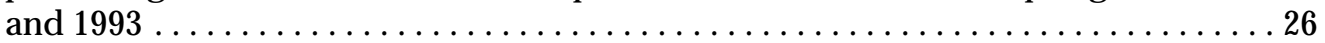

1.4. Photograph of suspended fine sediment flocs from a site in upper Chesapeake Bay

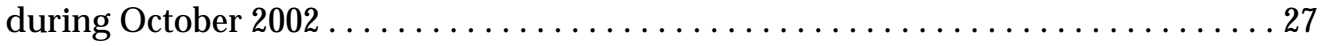

Chapter 2.

2.1. Graph showing land-use history and sediment yield from the Potomac River Basin in the northeastern United States, from the late 1700s to the 1960s, projected

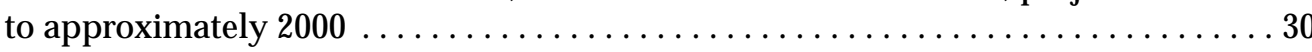

Chapter 3.

3.1. Sketch showing flow regimes affecting stream-channel and floodplain corridors..... 35

3.2. Diagram showing relations between profile location, sediment flux, and channel incision, defined as $\mathrm{dz} / \mathrm{dt}=\left(1 / \gamma_{\mathrm{s}}\right)(\mathrm{dG} / \mathrm{dx})+\mathrm{i}$, where $\mathrm{dz} / \mathrm{dt}=$ change in channel bed elevation with time, $\mathrm{dG} / \mathrm{dx}=$ change in bedload transport with distance downstream, $\gamma_{\mathrm{s}}=$ specific gravity of sediment $\ldots \ldots \ldots \ldots \ldots \ldots \ldots \ldots \ldots$

3.3. Graph showing changes in channel-bottom sediment sizes in the Fall Zone near

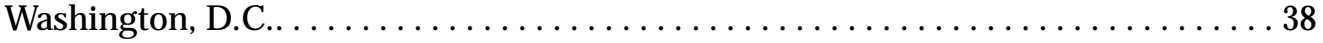




\section{FIGURES-Continued}

Page

3.4. Cross sections showing floodplain stratigraphy observed by Jacobsen and Coleman, partitioned into three defining periods of sedimentation . . . . . . . . . . . . 41

Chapter 4 .

4.1. Graph showing sedimentation rates from tree-ring and clay pads along selected Chesapeake Bay tributaries . . . . . . . . . . . . . . . . . . . . 45

4.2. Map showing location of three hydroelectric dams and reservoirs in the Lower

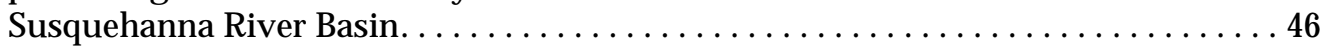

4.3. Graph showing change in Conowingo reservoir sediment-storage capacity,

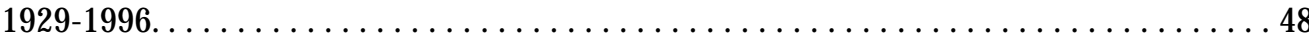

Chapter 5.

5.1. Pie charts showing relative contributions of sediment sources to the estuary with fastland erosion and with fastland and nearshore erosion.............. 50

5.2. Location map of the nine River Input Monitoring (RIM) Sites................. 52 5.3-5.4. Graphs showing:

5.3. River Input Monitoring station sediment data, 1985 to 2000.

(A) Average annual suspended-sediment load (log scale) and

(B) average annual sediment yield . ...................... 53

5.4. Combined annual suspended-sediment loads and relation to annual flow for the Susquehanna, Potomac, and the James Rivers near the Fall Line. . . . . . . . . . . . . . . . . . . . . . . . . . . 54

5.5. Diagram showing relation between fastland (above tide) erosion and nearshore

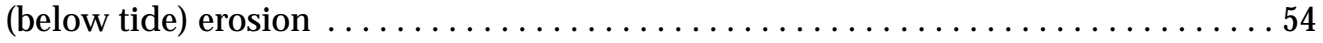

Chapter 6.

6.1-6.2. Maps showing:

6.1. Major pathways of sediment transport in Chesapeake Bay $\ldots \ldots \ldots \ldots \ldots 62$

6.2. General location of turbidity maxima (dark areas) for the major

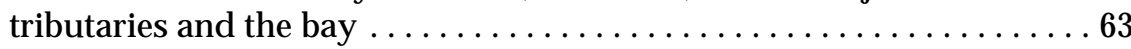

6.3-6.4. Graphs showing:

6.3. Graph showing proportion of ragweed (Ambrosia) pollen in core MD99-2209 showing the peak in ragweed between $201-241 \mathrm{~cm}$ depth corresponding to maximum agricultural and timber production land clearance $\ldots \ldots \ldots \ldots \ldots \ldots \ldots \ldots \ldots \ldots \ldots \ldots \ldots \ldots$

6.4. Graph showing age-depth model for core MD99-2209 showing series of radiocarbon ages (calibrated to years before 1950) and 2 sigma error bars....................................... 74

6.5-6.6. Maps showing:

6.5. Comparison of historical (1880-present) and long-term sediment

flux at core sites in Chesapeake Bay .................. 75

6.6. Estimates of sediment flux at different core sites in the Chesapeake Bay, calculated by determining the amount of sediment lying above the peak in ragweed pollen and converting to mass ............ 76 


\section{FIGURES-Continued}

Chapter 7.

7.1. Diagram showing watershed sediment, sinks and sources $\ldots \ldots \ldots \ldots \ldots \ldots \ldots 1$

7.2. Graph showing fine-grained sediment sources from different sources based on literature compared to model-generated loads ..................... 86

7.3. Schematic of a nested basin defined by upstream and downstream monitoring

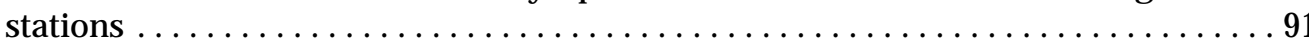

7.4-7.5. Graphs showing:

7.4. Modeled sediment-solids loads above and below the Fall Line . . . . . . . . 92

7.5. Relative proportion of light attenuation by component for major

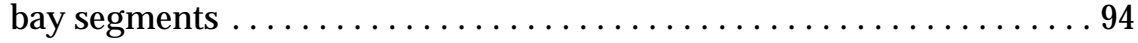

7.6-7.7. Maps showing:

7.6. Location of estuary model segment number as used in the water-quality

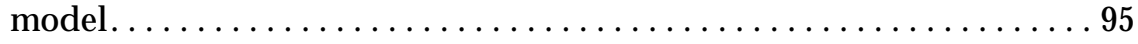

7.7. Estuarine areas that benefit more from sediment controls than from nutrient controls in the watershed and tidal tributaries . . ........96

\section{TABLES}

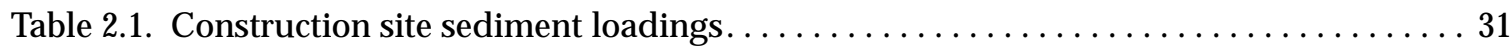

2.2. Post-development urban watershed sediment sources $\ldots \ldots \ldots \ldots \ldots \ldots \ldots \ldots \ldots \ldots \ldots \ldots$

2.3. Baltimore County Storm Water Management Module (SWMM) pollutant

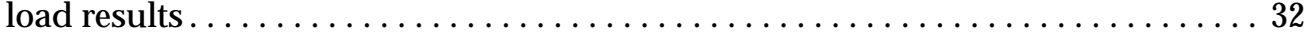

4.1. Mean sediment deposition rates for Coastal Plain rivers $\ldots \ldots \ldots \ldots \ldots \ldots \ldots 44$

6.1. Summary of sedimentation rates in Chesapeake Bay and tributaries from selected

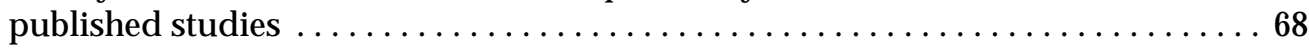

6.2. Summary of chronological and sedimentary rate data for Chesapeake Bay ....... 69

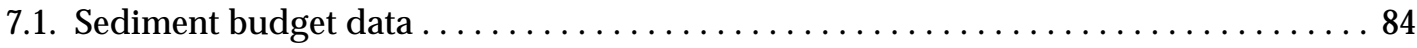

7.2. Suspended sediment source loads in the Chesapeake Bay estuary and its

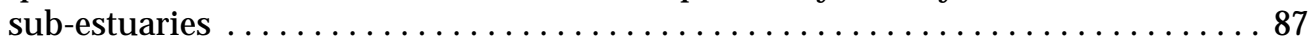

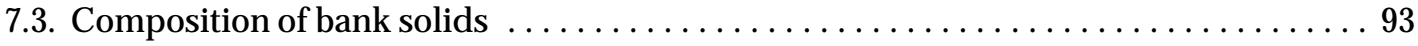

7.4. Sediment reductions for various best-management practices simulated in the Watershed Model ................................... 97 


\section{ACRONYMS AND ABBREVIATIONS}

\begin{tabular}{|c|c|}
\hline ADPC & Acoustic Doppler Current Profiler \\
\hline BMP & Best Management Practice \\
\hline CBEMP & Chesapeake Bay Estuary Model Package \\
\hline CIMS & Chesapeake Information Management System \\
\hline CBP & Chesapeake Bay Program \\
\hline ETM & Estuarine Turbidity Maximum \\
\hline GIS & Geographic Information System \\
\hline KGS & Kodak Grey Scale \\
\hline LIDAR & Light Detection and Ranging (technique used in remote sensing) \\
\hline MAR & Mass Accumulation Rate \\
\hline MWGOC & Metropolitan Washington Council of Governments \\
\hline NASQAN & National Stream Quality Accounting Network \\
\hline NAWQA & National Water Quality Assessment Program \\
\hline NESCI & National Estuary Sediment Contaminant Inventory \\
\hline NID & National Inventory of Dams \\
\hline NLCD & National Land Cover set \\
\hline NRCS & Natural Resources Conservation Service \\
\hline NRI & National Resources Inventory \\
\hline RADM & Regional Acid Deposition Model \\
\hline RIM & River Input Monitoring Program \\
\hline RF1 & River Reach File 1 \\
\hline SAV & Submerged Aquatic Vegetation \\
\hline SDR & Sediment Delivery Ratio \\
\hline SPARROW & Spatially Referenced Regression on Watershed Attributes \\
\hline SRBC & Susquehanna River Basin Commission \\
\hline SSC & Suspended Sediment Concentration \\
\hline STATSGO & State Soil Survey Geographic database \\
\hline SWGP & Sediment Workgroup \\
\hline SWMM & Storm Water Management Module \\
\hline TMDL & Total Maximum Daily Load \\
\hline TSS & Total suspended solids concentration \\
\hline TVSS & Total Volatile Suspended Solids \\
\hline USCOE & U.S. Army Corps of Engineers \\
\hline USEPA & U.S. Environmental Protection Agency \\
\hline USGS & U.S. Geological Survey \\
\hline USLE & Universal Soil Loss Equation \\
\hline WQM & Water Quality Model \\
\hline WSM & Watershed Model \\
\hline
\end{tabular}




\section{CONVERSION FACTORS AND ABBREVIATED WATER-QUALITY UNITS}

\section{Multiply}

inch (in)

foot $(\mathrm{ft})$

mile (mi)

yard (yd)

square mile $\left(\mathrm{mi}^{2}\right)$

gallon (gal)

acre-foot (acre-ft)

cubic foot per second $\left(\mathrm{ft}^{3} / \mathrm{s}\right)$

cubic foot per second per square mile $\left[\left(\mathrm{ft}^{3} / \mathrm{s}\right) / \mathrm{mi}^{2}\right]$

cubic foot per day $\left(\mathrm{ft}^{3} / \mathrm{d}\right)$

gallon per minute (gal/min)

gallon per day (gal/d)

gallon per day per square mile [(gal/d)/ $\left.\mathrm{mi}^{2}\right]$

million gallons per day (Mgal/d)

million gallons per day per square mile $\left[(\mathrm{Mgal} / \mathrm{d}) / \mathrm{mi}^{2}\right]$

pound, avoirdupois (lb)

ton, short $(2,000 \mathrm{lb})$

ton per acre

ton per day (ton/d)

ton per day per square mile

$\left[(\right.$ ton $\left./ \mathrm{d}) / \mathrm{mi}^{2}\right]$

ton per year (ton/yr)

ton per year (ton/yr)
By

Length

25.4

0.3048

1.609

0.9144

Area

2.590

Volume

3.785

1,233

Flow rate

0.02832

0.01093

0.02832

0.06309

0.003785

0.001461

0.04381

1,461

Mass

0.4536

0.9072

0.0002242

0.9072

0.3503

0.9072

0.9072
To obtain

millimeter

meter

kilometer

meter

square kilometer

liter

cubic meter

cubic meter per second

cubic meter per second per square kilometer

cubic meter per day

liter per second

cubic meter per day

cubic meter per day per square kilometer

cubic meter per second

cubic meter per day per square kilometer

kilogram

megagram

metric ton per square meter

metric ton per day

megagram per day per square kilometer

megagram per year

metric ton per year 


\section{CONVERSION FACTORS AND ABBREVIATED WATER-QUALITY UNITS-Continued}

Multiply

pound per cubic foot $\left(\mathrm{lb} / \mathrm{ft}^{3}\right)$

pound per cubic foot $\left(\mathrm{lb} / \mathrm{ft}^{3}\right)$

degree Fahrenheit $\left({ }^{\circ} \mathrm{F}\right)$

\author{
By \\ To obtain
}

Density

$16.02 \quad$ kilogram per cubic meter

0.01602 gram per cubic centimeter

Temperature

${ }^{\circ} \mathrm{C}=5 / 9\left({ }^{\circ} \mathrm{F}-32\right) \quad$ degree Celsius

Abbreviated water-quality units used in report:

$\mathrm{g} / \mathrm{m}^{2}$, grams per square meter $\mathrm{mg} / \mathrm{L}$, milligrams per liter 


\section{A Summary Report of Sediment Processes in Chesapeake Bay and Watershed}

\section{EXECUTIVE SUMMARY}

\section{by Michael Langland, Thomas Cronin, and Scott Phillips ${ }^{1}$}

The Chesapeake Bay, the Nation's largest estuary, has been degraded because of diminished water-quality, loss of habitat, and over-harvesting of living resources. The bay was listed as an impaired water body in 2000 under the Clean Water Act because of excess nutrients and sediment. Water-quality standards must be met in the bay by 2010. The Chesapeake Bay Program (CBP), a multi-jurisdictional partnership, completed an agreement called Chesapeake 2000 that revises and establishes new restoration goals through 2010 in the bay and its watershed. In the agreement, improving water quality is identified as one of the most critical elements in the overall protection and restoration of the Chesapeake Bay and its tributaries (fig. 1). Therefore, the authors of the report tried to extract, discuss, and summarize important aspects of sediment and sedimentation that are most relevant to the CBP and other sediment related-issues with which resources managers are involved. Many of these most important aspects are underlined throughout the report. The first of many important concepts is that excess sediment is one of the most important contributors to degraded water quality and has adverse effects on critical habitats (submerged aquatic vegetation (SAV) beds) and living resources (shellfish and finfish) in Chesapeake Bay and its watershed.

Sediment is solid material (soil and rock fragments) transported and deposited by wind, water, or ice; chemically precipitated from solution; or secreted by organisms. Sediment suspended in the water column consists of solid particulate organic and inorganic material (Chapter 1). This material can reduce water clarity and increase light attenuation such that light penetration commonly is below the thresholds needed

\footnotetext{
${ }^{1}$ U.S. Geological Survey.
}

to support healthy SAV. SAV beds constitute an important biological resource in estuaries. These beds influence the physical, chemical, and biological conditions of the estuary and provide critical habitat for many other species, in addition to their photosynthetic activity that produces organic material used by other plants and animals. In addition, SAV provides shelter and substrate for many invertebrate species including commercial shellfish and finfish. SAV also can contribute to improved water quality through uptake of nutrients during the SAV growing season, when excess nutrient levels can lead to excessive algal growth, increased turbidity, and oxygen depletion.

In the Chesapeake 2000 agreement, the CBP recognized that interim SAV restoration goals set in 1993 had not been met and that a new accelerated program of protection and restoration was needed. The strategy for SAV restoration is described in detail in a recent report submitted to the CBP Implementation Committee. As part of the effort to protect and restore SAV and meet waterquality standards in the bay, the CBP has committed to correcting the sediment and nutrient problems in the bay and its tidal waters. The goal of this commitment is the removal of the bay from the list of impaired watersheds by the year 2010. To do this, the CBP is committed to developing sediment and nutrient allocations for major basins within the bay watershed. The allocations would be used by the jurisdictions to revise nutrient- and sedimentreduction goals. Watershed-management plans that address the protection, conservation, and restoration of stream corridors, riparian forest buffers, and wetlands would be developed to meet the proposed goals. The CBP is also in the process of examining new and innovative management plans in the estuary itself and along the coastal zones of the bay that may decrease sediment influx and improve water quality. These commitments require information about sediment sources, transport, composition, and deposition in various parts of the bay and its watershed to formulate sedimentreduction management strategies. Specifically, information is required to develop sediment- 


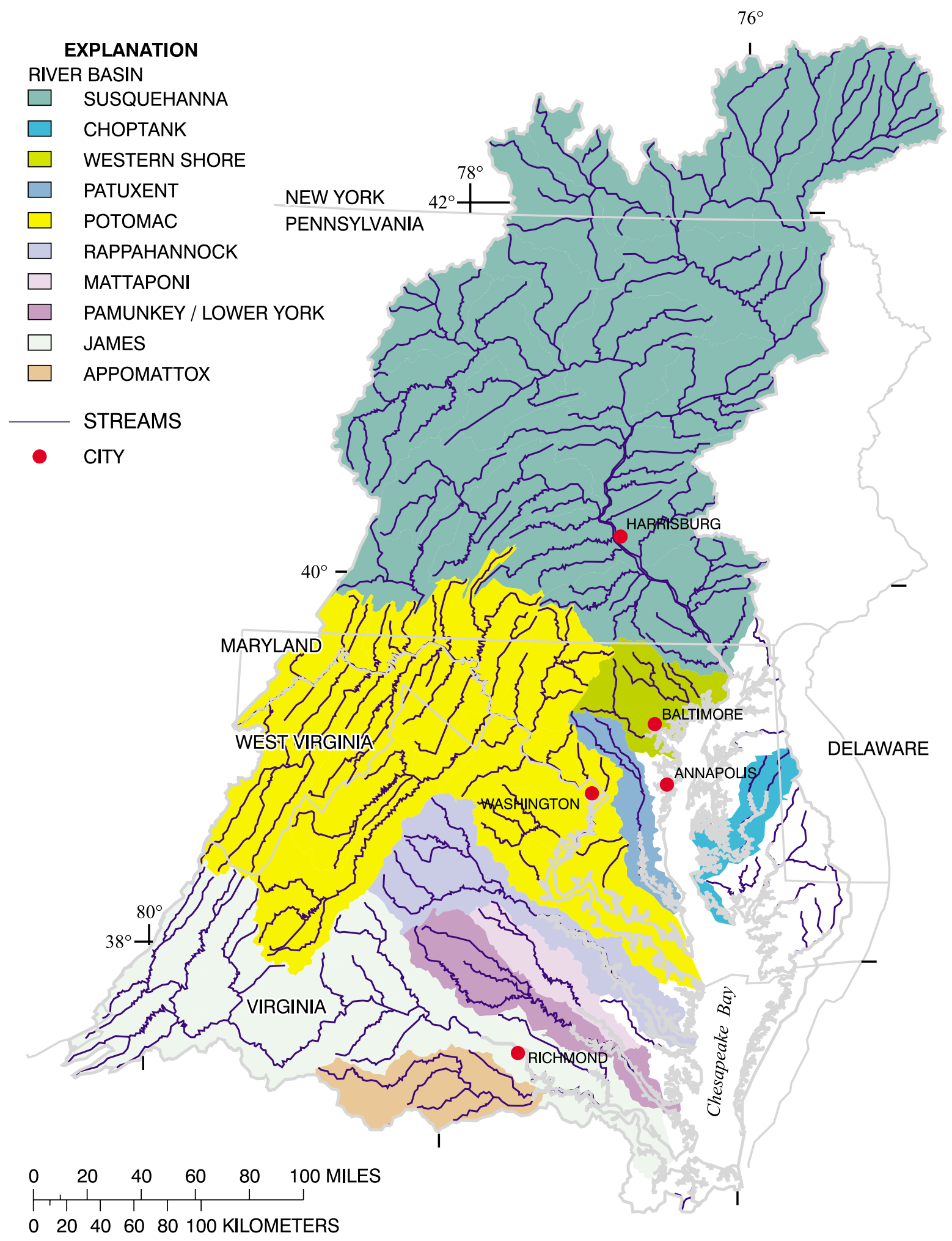

Figure 1. Location of Chesapeake Bay watershed and estuary. 
reduction strategies in 2003, to evaluated their initial effectiveness in 2005-06, and to assess whether water-clarity standards have been met by 2010.

In addition to its effect on water clarity, excess sediment can have other adverse effects on ecosystems. For example, sediment can carry toxic contaminants and pathogens that may negatively affect fisheries and other living resources. Excessive sedimentation also can degrade the vitality of oyster beds and other bottom-dwelling organisms in the bay and affect commercial shipping and recreational boating by accumulating in shipping channels. In the bay watershed, sediment is listed as the primary cause of impairment in many streams where it can severely degrade stream habitat and decrease benthic populations. Understanding estuarine and fluvial sedimentary processes is critical for improving water quality and living resources in the bay and should provide improved management of stream corridors and protection of eroding coastal zones in the watershed.

A Sediment Workgroup (SWGP) was created in April 2001 under the auspices of the Nutrient Subcommittee. It was recognized that reliable and up-to-date information on sediment processes in the bay and its watershed was widely dispersed in the literature and not readily accessible to the CBP and management community. This report presents the results and conclusions of the efforts of the SWGP; the highlights are given in this Executive Summary.

\section{Sediment and Suspended Solids}

A variety of conceptual and technical approaches have been used to study the origin, transport, and fate of particulate material in the Chesapeake Bay system. Sediment is a term describing particulate material. In estuaries like Chesapeake Bay, sediment consists largely of water-borne detrital material (pebbles, sand, mud) and varying amounts of particulate organic material. Over time, sediment may accumulate to form clastic rocks (conglomerate, sandstone, shale). However, most sediments deposited during the past 8,000 years in Chesapeake Bay are still unconsolidated. Sediment deposited during the last few centuries in the bay still contains more than 50-percent water content in pore spaces between sedimentary particles. The organic fraction of sediment collected from the bottom of the bay indicate sedi- ment consists of 1-3 percent organic material; the rest consists of inorganic mineral material and lesser amounts of shell material.

Sediment in the bay usually is studied by obtaining water column samples, bottom samples, and (or) sediment cores. These samples are then subjected to a variety of physical, chemical, and biological analyses depending on the scope and purpose of the research. Geologists describe sediment in terms of grain size, texture, mineralogy, and other characteristics. From the standpoint of water clarity, one of the most important characteristics of bay sediment involves the distinction between fine-grained sediment, which refers to the clay (less than $1 / 256-\mathrm{mm}$ diameter) and silt (1/256 to 1/16-mm diameter) -sized fractions, and coarsegrained sediment, which refers to the sand (1/16 2-mm diameter) and pebble (2-64 mm diameter) sized fractions. This fine/coarse distinction is important because most coarse material is transported along the bottom of rivers and the bay and has little effect on light penetration. In contrast, fine-grained sediment commonly is in suspension and, depending on its abundance, grain-size distribution, and degree of aggregation, can influence light penetration.

In contrast to research on sediment that has accumulated on the bottom of the bay and its tributaries, hydrologists and biologists commonly investigate particulate material suspended in the water and collected in a water sample (Chapter 1). This particulate material is referred to as either total suspended solids (TSS) or suspended-sediment concentration (SSC). These two measurements are used to quantify the concentrations of suspended solids in a water sample (Gray and others, 2000), and both are given in milligrams per liter. SSC is measured as the dry weight of total sediment in a sample divided by the amount of water-sediment mixture in the sample. TSS is measured by several methods, usually by taking a subsample of known volume from the original suspended-sediment sample, drying the sediment, and dividing by the known volume. Most suspended-solids measurements cited in this report refer to TSS.

The relation between fine-grained sediment loads (mass per unit time) to the bay and TSS concentrations in bay waters is not well understood. This is particularly true in terms of the chemical composition (organic versus inorganic), grain-size distribution, and aggregation state. The relation between rates of fine-grained sediment accumula- 
tion on the bottom of the bay and TSS concentrations in the water column is not clear. However, available information suggests that relatively high sediment accumulation characterizes regions of high turbidity such as the Estuarine Turbidity Maximum (ETM) zone in the northern bay. In this report, every effort was made to assimilate results derived from disparate studies of sediment and TSS into a consistent and meaningful context.

\section{Suspended Sediment, Water Clarity, and Submerged Aquatic Vegetation}

The amount of light reaching SAV living in shallow waters of Chesapeake Bay is influenced by many factors (Chapter 1). The most important properties in the water column are water color (usually discussed as dissolved organic carbon), concentrations and size distributions of TSS, and chlorophyll $a$. Collectively, these constituents decrease the amount of light reaching the leaf surface of SAV relative to their presence in the water column. Water column TSS consists of organic material, referred to as total volatile suspended solids (TVSS), and inorganic 'mineral' matter. Because TVSS consists of organic components of water (phytoplankton, heterotrophic plankton, bacteria, and particulate organic material), its relative contribution to TSS is related to nutrient concentrations and algal abundance. The inorganic mineral component of TSS, which commonly comprises greater than 50 percent of total TSS, generally consists of fine-grained silts and clays.

Therefore, inorganic sediment plays an important role in the degradation of water clarity in the bay. The relative abundance of inorganic sediment is related to various physical processes such as river discharge, tidal and wave erosion, estuarine circulation, and currents. Additional factors involving inorganic sediment abundance include local and regional geology, geomorphology, and land uses.

In addition to TSS and chlorophyll $a$ in the water column, epiphytes and other organic and inorganic material accumulate on the SAV leaf surfaces. This accumulation decreases light penetration, which is necessary for photosynthesis. Epiphyte abundance on SAV is itself influenced by nutrient loading and algal abundance. The amount of inorganic material settling on leaf surfaces is influenced by mineral sediment in the water column. Light attenuation by material settling on SAV surfaces is related closely to processes taking place in the water column.
Comprehensive analyses of TSS spatial and temporal variability in the Chesapeake Bay and its tributaries have yet to be carried out. Nonetheless, information available in the Chesapeake Bay Information Management System (CIMS) indicates a high degree of temporal and spatial variability in TSS concentrations. Bay-wide spatial variability in TSS concentrations during winter and spring seasons during relatively dry (1992) and wet (1993) years is shown in figure 2. These plots were constructed using seasonally averaged TSS data and spatial contouring analyses. They show two main features of bay TSS variability:

- High winter TSS concentrations during 1992 near the mouth of the bay reflect ocean-source sediments (see Chapter 3).

- High TSS concentrations in the northern bay and in the larger tributaries, especially during 1993, reflect high turbidity in the ETM zones (see Chapter 4).

Spatial analysis of TSS is useful to illustrate the complexity of TSS in the bay and allows for comparison with model-generated water-quality information and maps of SAV census and distribution data. Studies to date have suggested that time and space scales of sediment transport in the system can be quite short/small. Additional data on the shorter term, smaller scale variability of TSS would help to formulate and test a more accurate sediment-transport model for the bay. An improved model could lead to a better understanding of the relations between sediment sources and suspended-sediment distributions. Further discussion of TSS variability is given in Chapter 1.

An additional complexity not reflected in the TSS patterns is that the grain size characteristics of TSS also can influence the amount of light attenuation because of different optical characteristics of different material. Additional research on TSS, especially studies that determine TSS size and composition, is necessary for a better understanding of the relative proportions and physical characteristics of inorganic and organic sediments and their sources throughout the bay system.

In summary, the literature indicates that the physical and biological processes governing inorganic and organic sediment production, transport, and deposition are complex and related to one another. For example, management efforts to reduce nutrient loadings also might help improve water clarity by affecting the levels of particulate material in the water column and algal epiphyte 
WINTER 1993
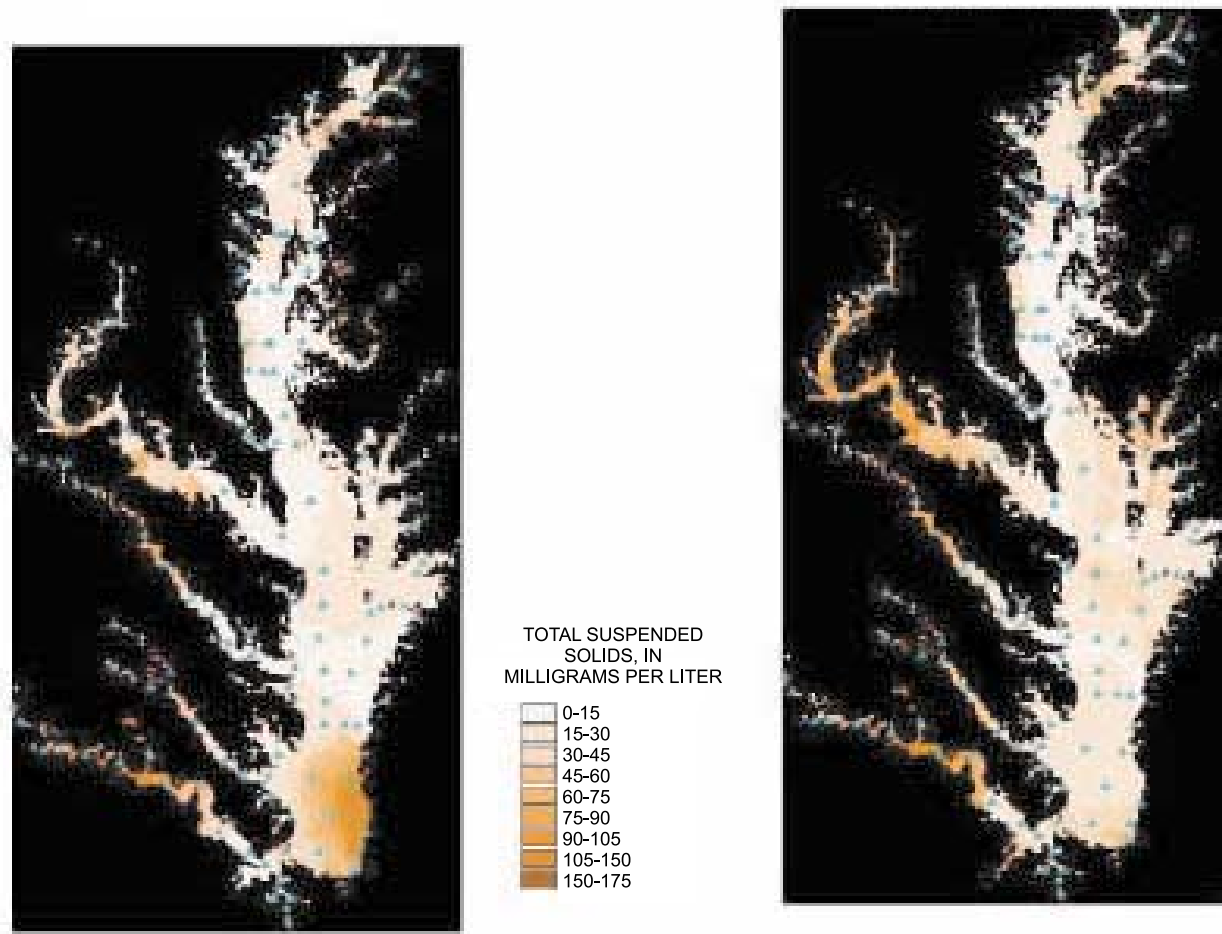

TOTAL SUSPENDED

TOTAL SUSPENDED SOLIDS, IN MILLIGRAMS PER LITER

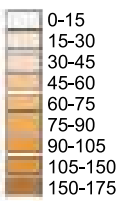

TITER

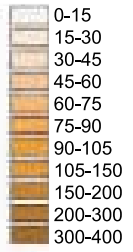

SPRING 1992

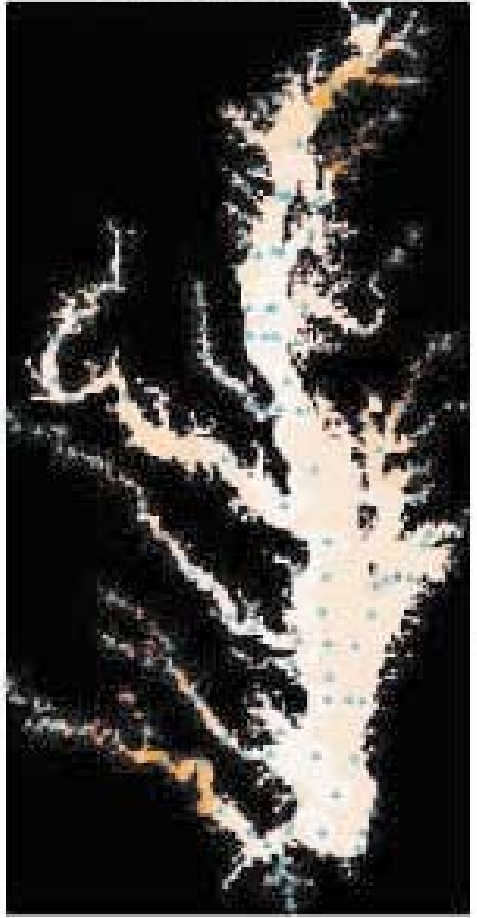

TOTAL SUSPENDED SOLIDS, IN
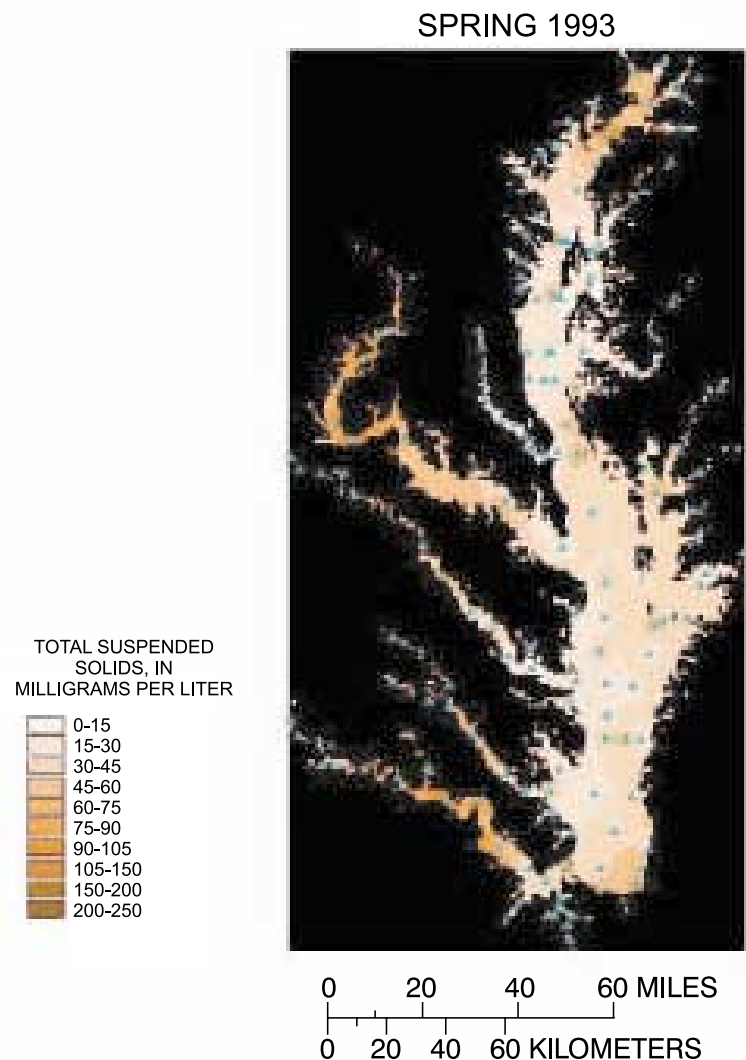

TOTAL SUSPENDED SOLIDS, IN MILLIGRAMS PER LITER

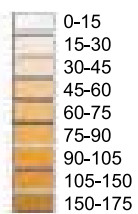

Figure 2. Concentrations of total suspended solids in winter and spring, 1992 and 1993. (Total suspendedsolids data from Chesapeake Bay Program, Annapolis, Md., Chesapeake Information Management System.) 
growth on SAV plants. Future research programs and management strategies to control chlorophyll $a$ and nutrient loadings could be coordinated with efforts aimed at reducing the concentration of inorganic sediment. The cumulative effects of organic and inorganic material on light attenuation need to be considered in management plans.

It also is clear, however, that the physical processes governing the introduction, transport, re-suspension, and deposition of inorganic sediment are distinct from biological production of particulate material driven by nutrient concentrations and primary production. Primary production is defined as organisms, such as algae, that convert solar energy to organic substances through the molecule, chlorophyll. Primary producers serve as a food source for higher organisms. Consequently, management practices aimed at reducing nutrient concentrations may not be sufficient to reduce the influence of inorganic sediment on water clarity. Allocations for inorganic-sediment reduction ultimately will be distinct from those for nutrients. In addition, the spatial variability in sediment source and the physical processes influencing inorganic sediment transport and deposition need to be considered. The remaining sections in the executive summary and following chapters in the report describe these processes and their relevance to water clarity.

\section{Watershed Sources and Transport of Sediment}

A large proportion of sediment that enters the Chesapeake Bay is derived originally from erosion in the bay watershed. Erosion from upland land surfaces and erosion of stream corridors (banks and channels) are the two most important sources of sediment coming from the watershed. Sediment erosion is a natural process influenced by geology, soil characteristics, terrestrial habitat cover (land cover), topography, and climate.

Some generalizations can be made about erosion, sediment yield (mass per unit area per unit time), and land use in the bay watershed (Chapters 2 and 3 ).

- For the entire Chesapeake Bay region, river basins with the highest percentage of agricultural land use have the highest annual sediment yields, and basins with the highest percentage of forest cover have the lowest annual sediment yields.
- Urbanization and development can more than double the natural background sediment yield; the increase in sediment yield is highest in the early development stages.

- After development is completed, erosion rates are lower; however, sediment yield from urbanized areas can remain high because of increased stream corridor erosion due to altered hydrology.

- One study in an urban setting estimated $2 / 3$ of the sediment in the water column was from streambanks and $1 / 3$ was from upland erosion.

- Other activities also influence upland erosion. For example, mining for coal and minerals, although in decline in the watershed from historical levels, still contributes fine particles from "reworked" piles to rivers. This can increase sediment yields above background levels.

- Most of the sediment yield from the watershed to the bay is transported during bankfull conditions, which take place on average every 1-2 years, and during relatively large storm events. Hence, sediment input to the bay potentially can be affected by large-scale patterns of climate change.

Despite these generalities, one of the most important conclusions drawn by the SWGP was that the relative contribution of upland sediment and the sediment stored in stream corridors has not been quantified in the bay watershed. Such information is important to formulate effective sediment-reduction strategies.

Another important conclusion involves the historical changes in the generation and delivery of sediment from watershed sources to the estuary. Natural pre-colonization erosional processes have been severely disrupted since the 17th century as a result of land-use practices. During the 18th and 19th centuries, the amount of land cleared for agriculture and timber production was extensive. During this time, 70-80 percent of the original forest cover was cleared. This land disturbance increased erosion rates in the bay watershed, leading to greater amounts of sediment transport from the land surface toward the bay and its tributaries. The trend toward deforestation peaked in the late 1800 s and was reversed during the 20th century when reforestation increased. Erosion rates, in theory, should have decreased during this period. How- 
ever, urbanization and the remobilization of previously eroded sediments may have contributed to continued high erosion rates during the past few decades.

Quantitative region-wide data on decadal trends in erosion over the past few centuries are lacking. The rates of erosion can be inferred from long-term changes in sediment mass accumulation obtained from geological studies of sediment cores in the bay and tributaries. These studies indicate a four- to five-fold increase in sediment mass accumulation in some parts of the bay since the $1800 \mathrm{~s}$ (fig. 3). However, in contrast to areas experiencing large increases in sediment loads, other regions experienced little or no change in post-colonization sediment rates. This indicates that the effect of land clearing on sediment accumulation was not uniform throughout the bay system and varied according to watershed histories. In addition, physical processes controlling erosion and deposition in the bay itself may vary.

The substantial lag time between upland and stream-channel erosion and eventual transport and deposition into critical bay habitats is not well documented. Much of the sediment eroded from cleared land during colonial times may still be stored in upland areas and in stream corridors. These storage areas include riparian areas and reservoirs, small tidal tributaries, and lowland floodplain zones. It is unknown what proportion of sediment eroded during land clearance is stored in channels and tributaries and what proportion actually has reached the bay. This temporarily stored sediment-sometimes referred to as "legacy sediment" - will ultimately make its way to the bay. However, it may take decades or longer, depending on its location in the watershed and future climatic and hydrologic factors. Therefore, future improvements in water clarity may take years to decades following implementation of land-use changes in the watershed. For this and other reasons addressed below, the CBP may want to consider land-based practices nearer the tidal portions of the bay and its tributaries and additional management strategies both along and in the bay coastal zones to help meet water-clarity goals by 2010.

\section{Sediment Sources and Transport to the Bay and Tributaries}

The primary sources of fine- (clay and silt) and coarse (sand and gravel) -grained sediment into the main bay are input from the main rivers in the watershed, input from smaller tributaries and streams, erosion from shorelines and coastal marshes, ocean input at the mouth of the bay, and internal biogenic production of skeletal and organic material. A generalized map of pathways for sediment movement is shown in figure 4; major sediment sources to the bay are shown in figure 5 . On the basis of these figures and additional information discussed below, five generalities about sediment movement and sources can be made (Chapters 5 and 6).

1) Although estimates of the relative contributions of different sediment sources in any particular region vary among different authors, it generally is agreed that in the northern bay, the Susquehanna River is by far the dominant source of sediment influx; in the southern bay, shoreline erosion and influx from the ocean is the dominant source; and in the central bay, the majority of sediment influx comes from shoreline erosion or is produced internally by biological processes. Most sediment entering the bay from the Susquehanna River is trapped by the ETM zone, which is a region of high turbidity in the northern bay (see below).

2) For rivers on the western shore, watershed inputs are the primary source of sediment delivered to tidal fresh regions of tributaries. As in the main stem, there is an ETM zone upstream in the larger tributaries. For regions of western shore tributaries downstream of the ETM zone, and in most Eastern Shore rivers, coastal plain tributaries and shorelines are more important sources of sediment. Implication for the tidal tributaries could be to focus on sediment sources in the watershed to help improve clarity in the tidal fresh zones and focus more on fastland (above tidal water) and nearshore (below tidal water) sources of sediment to improve clarity downstream of the ETM zone in each tributary.

3) Export from tributaries to the main stem bay is a complex subject with differing opinions expressed in the literature. Many researchers have suggested that much of the sediment transported into the major tidal tributaries from major rivers, smaller tributaries, and shoreline erosion is deposited in the tributaries. Other researchers, however, 


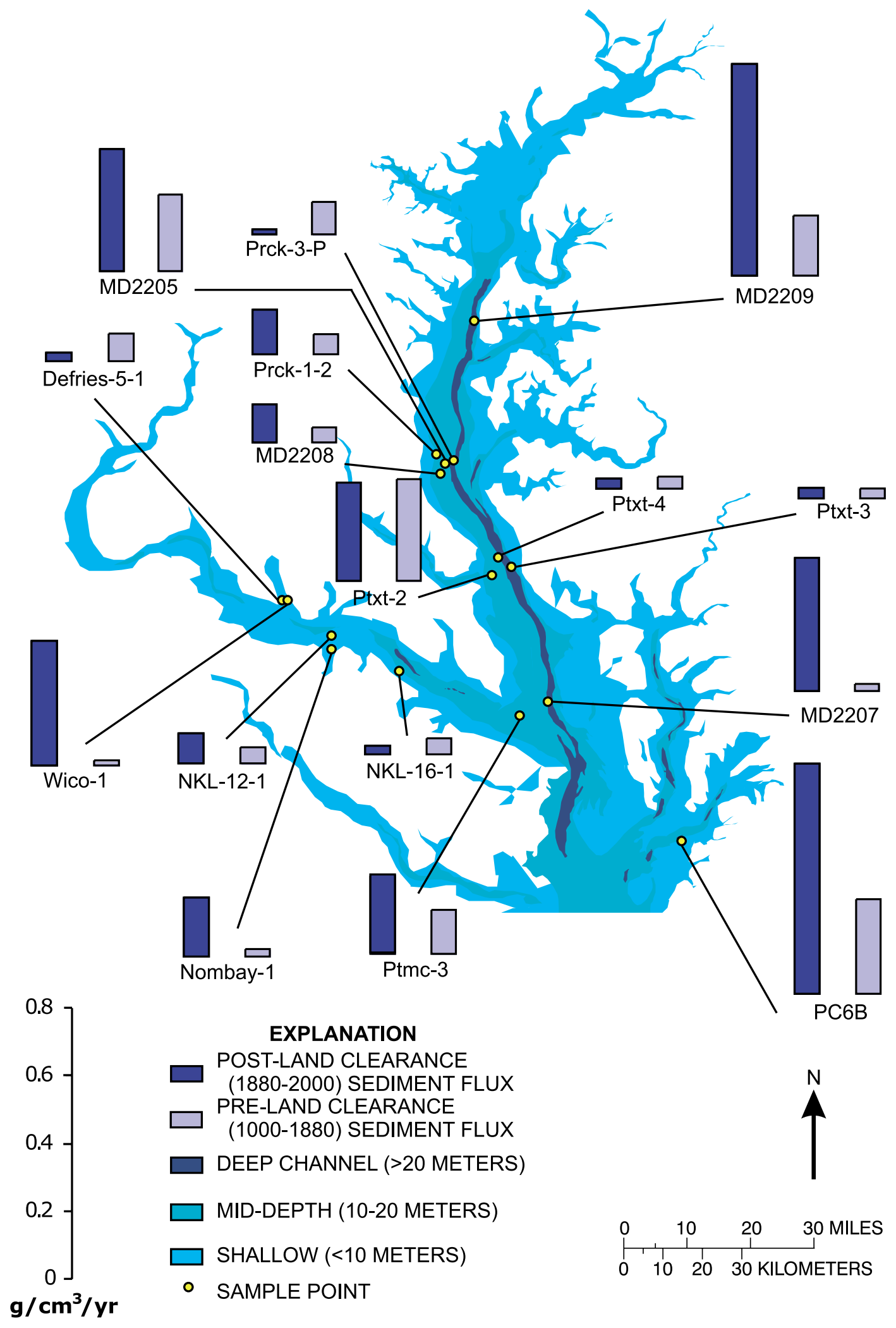

Figure 3. Comparison of historical (1880-present) and long-term sediment flux at core sites in Chesapeake Bay (determined by methods and data described in Chapter 6, table 6.1). 


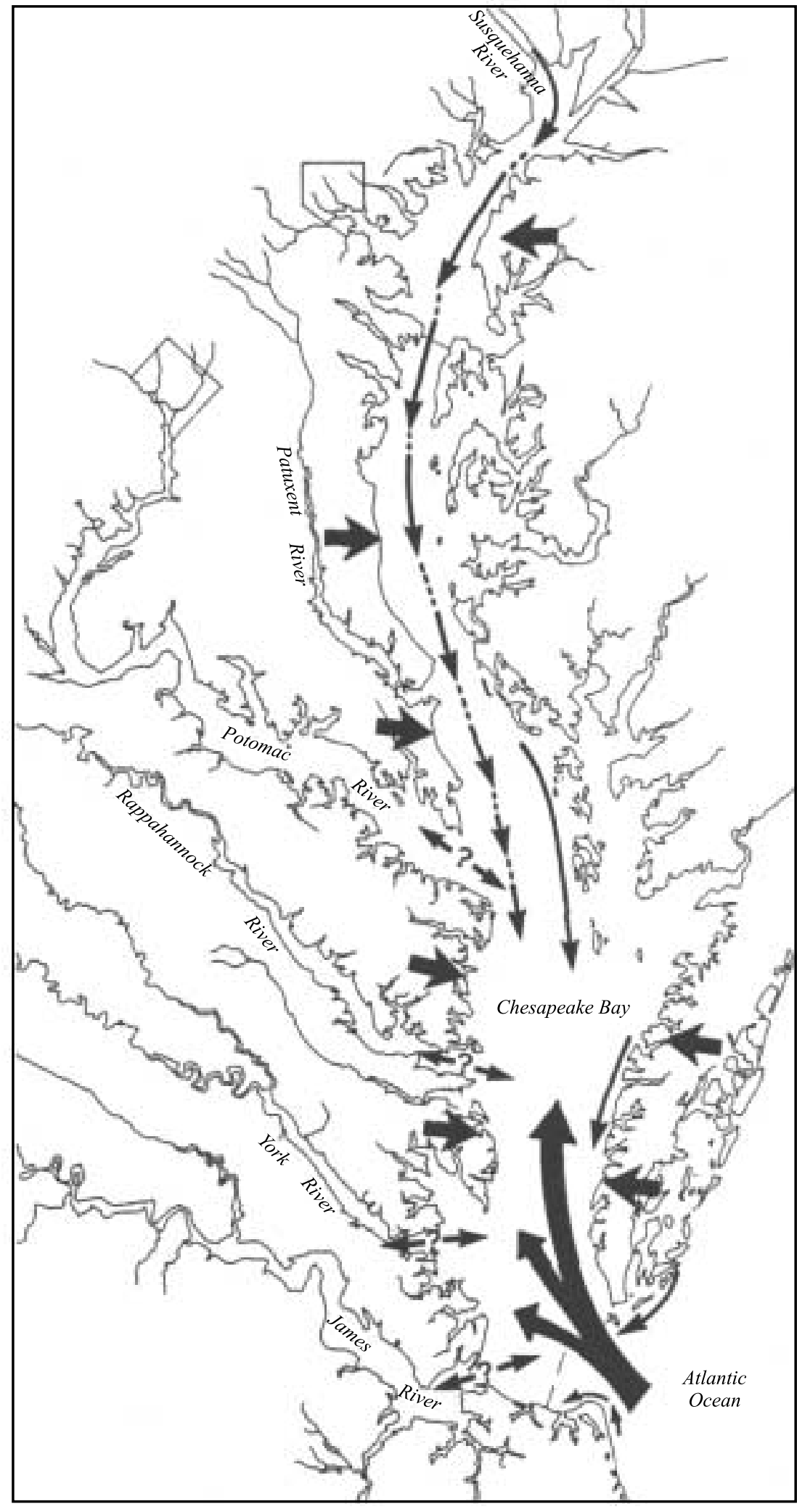

Figure 4. Major pathways of sediment transport in Chesapeake Bay (from Hobbs and others, 1990). (Note, the thickness of arrows does not equate to amount of mass transported.) 


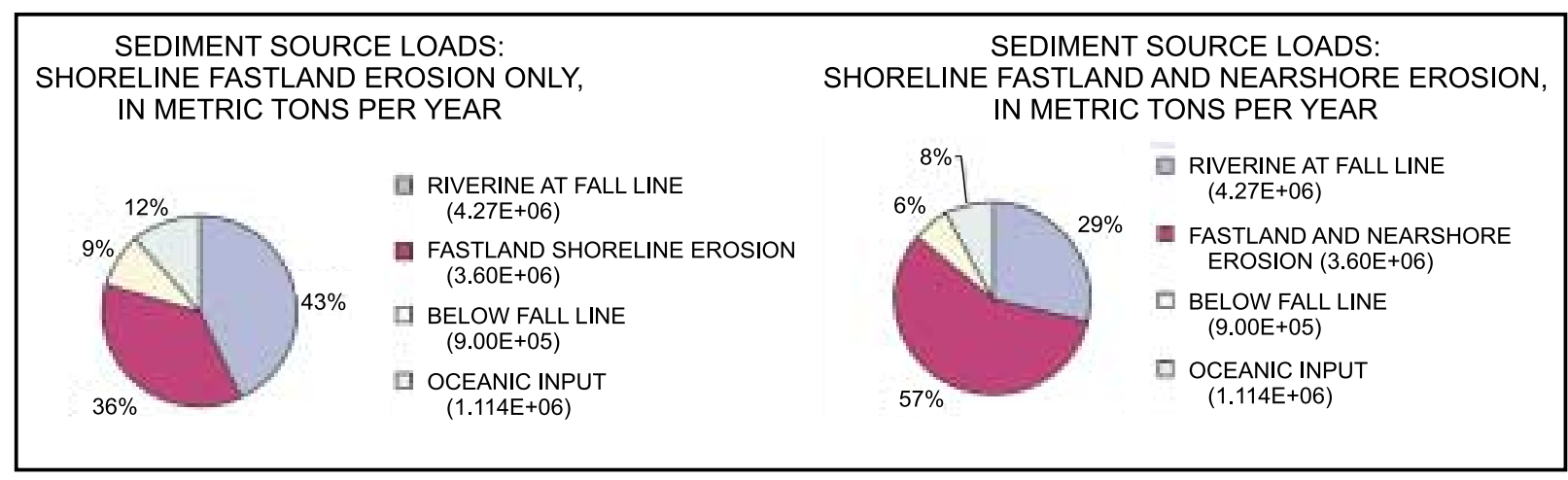

Figure 5. Relative contributions of sediment sources to the estuary with fastland (above tidal water) erosion (left) and with fastland and nearshore (below tidal water) erosion (right). (Based on data in chapter 7, table 7.2, and U.S. Army Corps of Engineers, 1990.)

have suggested substantially more export of sediment out of tributaries and into the bay than generally is believed. This is especially true during extreme weather events, such as Tropical Storm Agnes, or sustained periods of high freshwater inflow, when a substantial amount of sediment can be exported into the main stem bay. Obtaining quantitative data on this issue would require extensive field studies.

4) Whereas northern and southern bay sediment sources are dominated by the Susquehanna River and shoreline and ocean input, respectively, the sources of sediment entering the central bay are less well known. Early studies suggested as much as 18 and 22 percent of suspended material in the central bay came from skeletal material and organic production, respectively, and as much as 52 percent came from shoreline erosion. A number of studies, using geochemical tracers in sediments, satellite images, buoys, and other methods, provide evidence that fine-grained material may be transported southward out of the ETM zone and northward from ocean sources into the central bay region. This material may play an important role in many critical SAV regions. However, quantitative estimates of the relative proportion of fine-grained sediment transported southward and northward into the central bay compared to local shoreline erosion and biogenic production remains one of the uncertainties of sediment transport within the bay proper.

5) Little or no sediment is exported from the bay to the adjacent ocean except during extreme climate events causing high freshwater inflow from the watershed. This reflects the overall sediment trapping nature of the entire bay system.
To obtain quantitative data on the sediment pathways and sources discussed above, the SWGP compiled available data on the relative contributions of fine-grained sediment loads into regions of the bay and in certain tributaries based on some of the more comprehensive research papers. These data are presented in figure 5 and expressed as mass and percent contribution. Coarse-grained sediments (sand and gravel) are not considered in this analysis, although data on coarse sediment is extensive in the literature. These data are further classified and plotted by source and compared to sediment mass contributions from different watersheds as estimated by the CBP Water Quality Model Scenario from 2000 (fig. 6).

Six potential sources of sediment shown in figure 6 are described as follows: (1) Riverine input is defined as suspended sediment transported by the major rivers entering the bay and usually measured by monitoring stations near the Fall Line Zone. (2) Tributary input is defined as sediment entering the tidal parts of major tributaries from smaller rivers draining the Eastern and Western Shore. (3) Shoreline sources are defined as sediment derived mainly from bank and headland erosion, although low-lying coastal marshes also contribute. (4) Biogenic sediment has two components-skeletal material and particulate organic material, both produced by organisms. Biogenic sediment commonly is not measured in studies of sediment flux in the bay. Therefore, values for the proportion of biogenic material commonly are not available. (5) Import of sediment signifies sediment imported from the main stem into larger tributaries. (6) The last source of sediment is the import into the bay through its mouth from ocean sources. This sediment ultimately comes from the 
SOURCES OF SILT/CLAY SEDIMENT LOADS

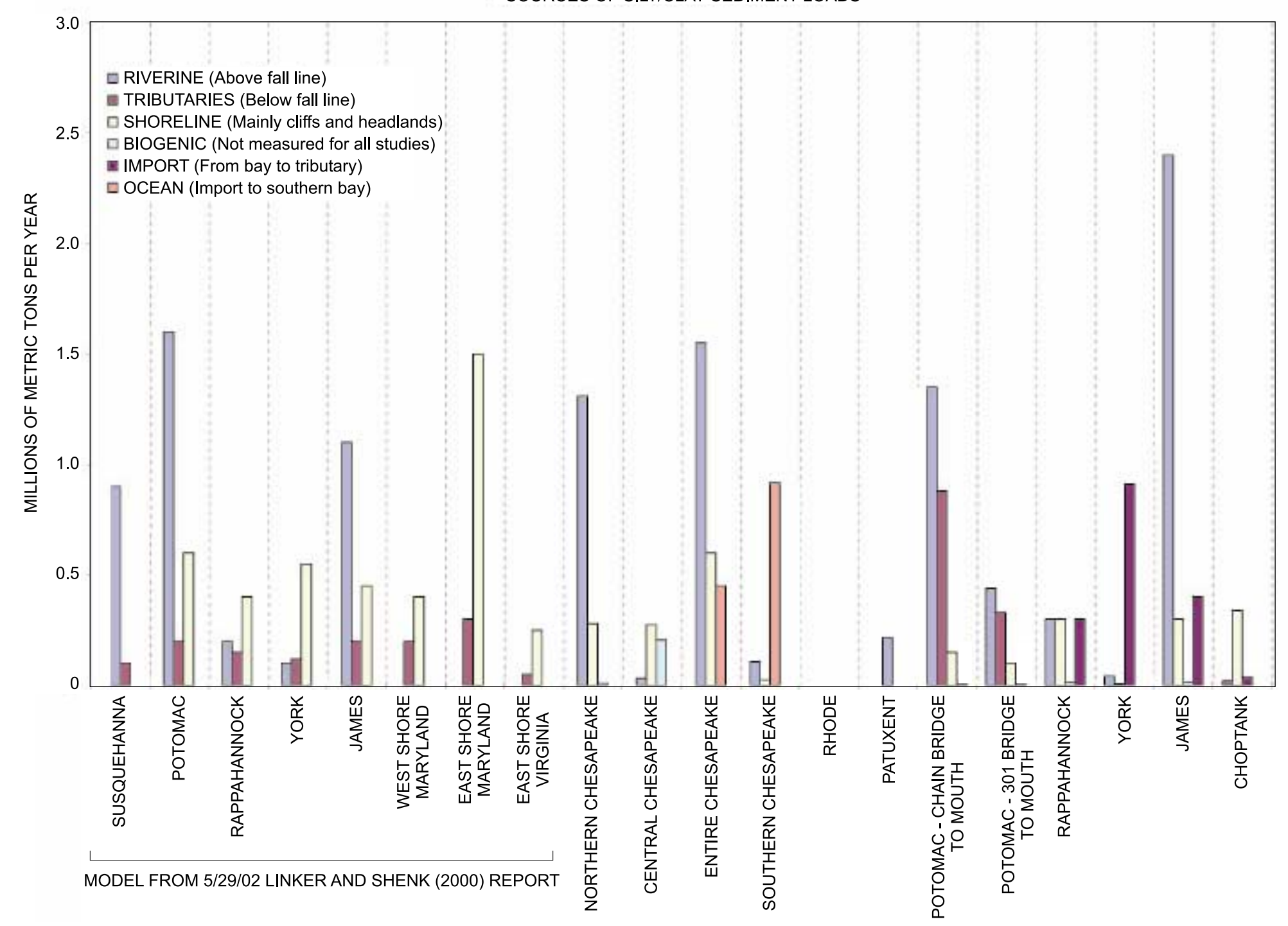

Figure 6. Sources of fine-grained sediment from different sources based on literature (right half) compared to model-generated loads (left half) (Based on table 7.2 in chapter 7). 
continental shelf and coastal regions of the southern Delmarva Peninsula and is subject to complex depositional and erosional patterns in the bay mouth region.

Several important conclusions can be drawn from the data in figure 6:

- Susquehanna River sediment dominates in the north.

- Oceanic-source sediment is the dominant source in the southern bay, although this total includes an unknown amount of sediment eroded from shorelines and perhaps some sediment exported from major rivers. A further breakdown of this large load of sediment requires more detailed analysis.

- Different tributaries have different relative contributions from riverine, shoreline, biogenic, and oceanic sources.

- In different parts of large tributaries such as the Potomac and James, the relative proportion of shoreline and riverine sediments vary in upstream and downstream regions. This reflects the trapping of riverine sediments by the ETM zone and the diminished influence of riverine sources further downstream in a major tributary.

- Shoreline sources of sediment are numerically important in the Choptank and Rappahannock tributaries and to a lesser extent in the Potomac and York Rivers.

Although the comparison of empirical and model-generated sediment loads is illustrative, caution is urged because of different definitions of regions in the two data sets. Moreover, the values in figure 6 do not distinguish resuspended sediment, which might overwhelm the loading of newly introduced sediment in some regions under certain conditions (see below). Further data-model evaluation might minimize the discrepancies of the shoreline erosion loads by using more recent and spatially detailed estimates of shoreline erosion.

The improved database available from the literature on sources and transport of sediment in various regions of the bay and its tributaries suggests additional modifications to sediment-management strategies in the future may be considered. For example, the water-quality model for Chesapeake Bay may be used to guide sediment-reduction strategies. Currently, the model considers load estimates from the watershed model calibrated from TSS data collected at the River Input Monitoring sites, estimates of sediment inputs from below the River Input sites, and from estimates of shoreline sediment input based on estimates determined by Ibison and others (1992). In the future, it will be most important to integrate refined sediment-source estimates not only for shoreline and riverine input, but also for biogenic and oceanic sources of sediments into Chesapeake Bay. In addition to factoring in all potential sources of sediment influx and resuspension, modeling simulations may begin to integrate knowledge of the spatial and temporal variability in shoreline erosion summarized below and discussed in detail in Chapter 5 of this report.

\section{Shoreline Erosion}

The contribution of shoreline erosion to total suspended sediment deserves special comment for several reasons (Chapter 5). First, shorelines are retreating because of the relatively rapid rate of sea-level rise ( $1.3 \mathrm{ft}$ for the last century) (Cronin and others, 2000) in the Chesapeake Bay and MidAtlantic coast. This rate is twice that of the worldwide average and is the result of regional land subsidence and ocean warming. Although estimates of the future rate of sea-level rise caused by global warming include an extremely high degree of uncertainty, most experts expect an acceleration of sea-level rise. This acceleration implies greater coastal submergence and perhaps shoreline erosion in low-lying regions of the Chesapeake Bay area. The regions vulnerable to sea-level rise over the next century are shown in figure 7.

A second critical aspect of shoreline erosion is that most research indicates the relative contribution of shoreline erosion is variable, and may be as high as 80 percent or more of the total finegrained sediment load in the central part of the main stem, south of the bay ETM zone, and in the central regions of large tidal tributaries. Because the Bay Program Water-Quality Model currently assumes one value (uniform rate) from finegrained shoreline erosion, it will be important in future model development and implementation of management actions to take into account variability in shoreline loads.

The third important aspect of shoreline erosion involves potential management efforts to reduce total sediment input into the bay system. As discussed below and in Chapter 4 of this report, 


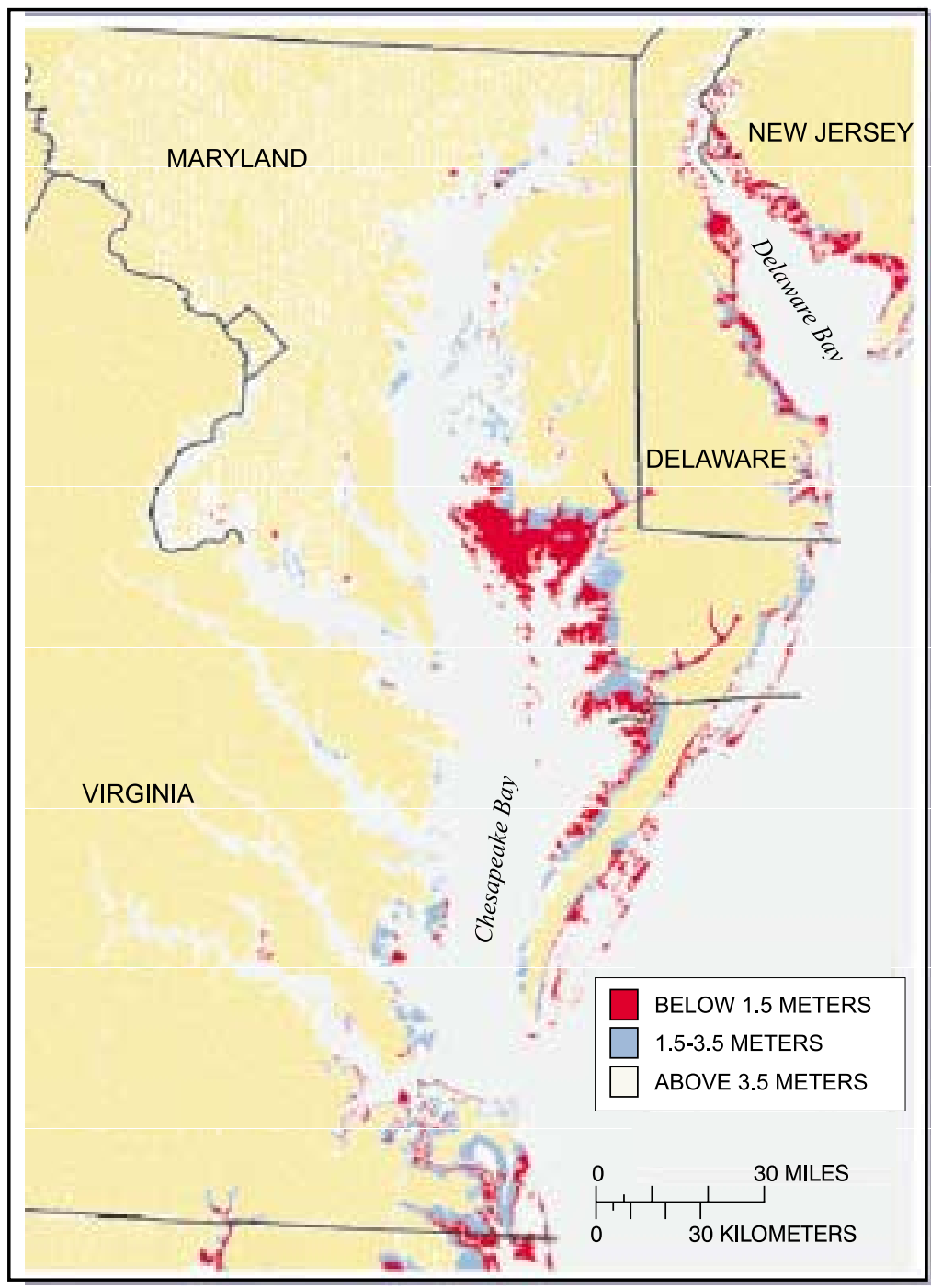

Figure 7. Vulnerability of low-lying regions around Chesapeake Bay to future sea-level rise. Future sea-level projections are uncertain but areas shown in red are most vulnerable to submergence and/or storm surges (from Titus and Richman, 2001).

sediment derived from the watershed upland and stream channels can take years to decades or longer to actually reach the lower tidal tributaries and the main stem of the bay. Although the transit time is not known precisely, it is clear that the implementation of management practices in the watershed most likely will not have an immediate effect on bay water clarity because of sedimenttransport processes. In contrast, management actions to protect and maintain the extensive shorelines of the bay system may have a more immediate effect on decreasing sediment loads into parts of the estuary.
It is important to remember that, although excess sediments may be detrimental for SAV growth, a certain amount of suspended sediment is necessary for the health of other systems in the bay and its tributaries. For example, sediment is critical to maintaining the elevation of tidal wetlands. An important source of sediment for these wetlands is from overbank flooding (i.e. suspended sediment in the riverine and/or estuarine waters). Suspended sediment in littoral cells is also a natural source of material for beach progradation (beach growth) in some areas. 
Finally, three important points about shoreline erosion require emphasis. First, shoreline erosion can occur in both "fastland" (above tidal water) and nearshore (below tidal water) zones. Fastland erosion accounts for one-third and nearshore erosion accounts for two-thirds of the estimated shoreline erosion. However, most studies have focused on quantifying fastland erosion inputs. The rate for fastland erosion is used in the Water-Quality Model (model used by the Chesapeake Bay Program to simulate water-quality conditions in the estuary). Therefore, shoreline erosion may be underestimated because of the non-inclusion of the nearshore component.

The second point involves grain size, which strongly influences light attenuation. In WaterQuality Model simulations, about 33 percent of the total shoreline contribution to suspended sediment was considered to be sand- and gravel-sized (and thus not usually suspended). These assumptions are based on the work of Ibison and others (1992). The literature on grain size for sediments deposited in the bay and source sediments that outcrop along the bay margins is extensive. Data from three of the more extensive studies are compared to the fine- and coarse-grained breakdown used in CBP model simulations (fig. 8). The figure shows that the Ibison and others (1992) coarse/fine ratio is similar to that obtained by Hobbs and others (1992) for the Maryland part of the bay. However, shoreline sediment from the southern bay (Byrne and others, 1980) and from the tidal part of the Potomac River (Miller, 1987) has a relatively greater proportion of coarse sediment than in the Ibison and others (1992) estimates.

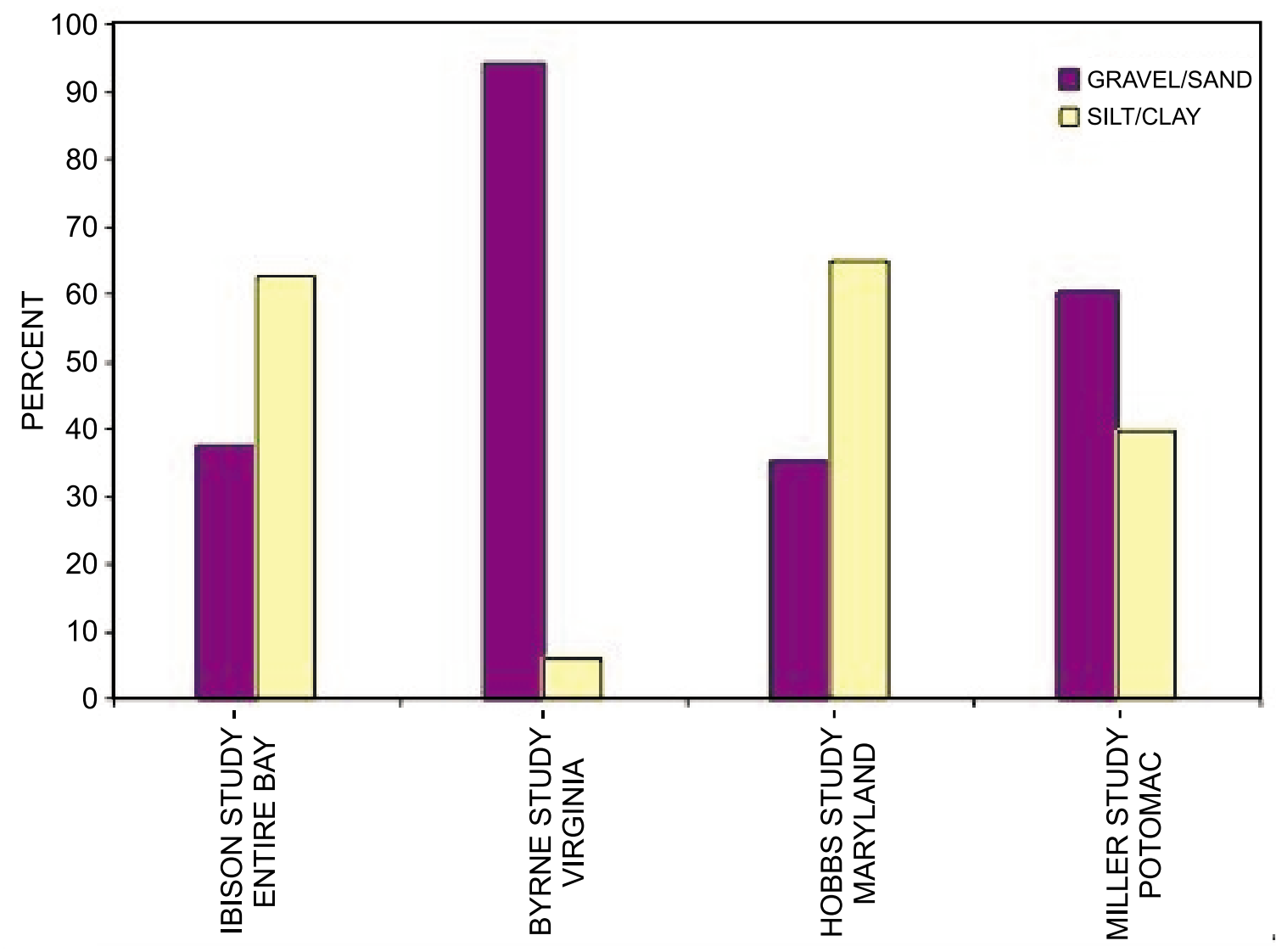

Figure 8. Comparison of coarse- (sand, gravel) and fine-grained (silt, clay) components of shoreline sediments from different studies. (Sources: Ibison and others, 1992; Byne and others, 1980; Hobbs and others, 1992; and Miller, 1987.) 
The third and one of the more important conclusions of the SWGP is that shoreline erosion of banks and coastal marshes is a large source of fine-grained suspended sediment. However, amounts vary greatly depending on the region and location. Given that shoreline erosion is likely to become an increasing source of sediment if the rate of future sea-level rise accelerates, shoreline-protective measures may be an important component in future management actions.

\section{Natural Processes and Variability in Sediment Transport}

Several natural physical processes exert a strong influence on the transport, resuspension, and deposition of sediment in the bay and its tributaries (Chapter 6). The variability stemming from these processes poses a degree of complexity and additional challenges for managers in Federal, State, and local government agencies in developing management strategies to improve water clarity. The most important processes include precipitation and river discharge associated with climatological variability, wind-generated wave and tidal current sediment resuspension in the estuary, and tidal- and current-generated sediment input from the ocean near the mouth of the bay.

Climatological processes operate over various timescales and are responsible for brief, intense weather events (hurricanes and storms) and seasonal, year-to-year, and decadal changes in rainfall, river discharge, and sediment loads. For example, it has been estimated that Tropical Storms Agnes (1972) and Eloise (1975) transported 40 million tons of sediment into the estuary. This amount is about equivalent to the amount of sediment normally transported from the entire watershed in 10 years. Such events also can lead to southward export of sediment out of the ETM zone from the northern bay into the central bay. Similarly, strong storm events can reverse the long-term pattern of bay-to-tributary import of sediment and cause sediment to be exported from major tidal tributaries into the main stem of the bay.

Over intermediate timescales (seasonal to decadal), climatological research using available records and paleoclimate data obtained from sediment cores and tree-rings indicate that over the past few centuries, seasonal and multi-year droughts alternate with relatively wet periods. This natural variability leads to cyclic-like changes in bay salinity, sediment transport, deposition, and composition as illustrated in the cyclic pattern of fine- and coarse-grained sediment from a region off the Little Choptank River (fig. 9). This interannual climate-driven variability in sediment characteristics occurs in conjunction with changes in nutrient loads and changes in biogeochemical cycling. These changes have had strong effects on the living resources of the bay. In particular, interannual climate variability influences the productivity, biogenic production, phytoplankton dynamics, and, ultimately, water clarity and SAV populations of the bay.

Another natural process that influences water clarity is sediment resuspension, especially in the ETM zone and shallow waters. Resuspension involves complex processes controlled mainly by wind-driven wave action, density-driven (salinity) estuarine circulation influenced by freshwater discharge from the Susquehanna River and other tributaries, and by tidal processes to a lesser extent. Biological processes in the water column further complicate inorganic sediment movement controlled by these physical processes. The production of organic particulate matter becomes mixed with inorganic material, influencing light attenuation and physical settling rates. Resuspension of bottom sediment produces an enormous mass of suspended matter that can diminish water clarity. For example, estimates of total suspended load in the deeper parts of the main stem bay in the ETM zone can reach 135,000 metric tons per day, compared to combined daily suspended matter load input from the Susquehanna River, shoreline erosion, and biogenic sources of only 4,400 metric tons. Resuspension of fine-grained material is most prominent in the deeper parts of the bay where fine-grained sediment is dominant. Once in suspension, however, fine-grained sediments can influence shallow water habitats if it is circulated by wind-driven currents and transported to margins of the bay. Thus, the potential contribution of sediment resuspension processes in deeper water may need to be considered when managing shallow-water SAV habitats.

Land-based management actions may reduce sediment loads in rivers. However, extreme weather events, climate variability, and tidal resuspension of sediment will continue to effect water clarity even if sediment delivery from the land is reduced. Although these natural processes themselves cannot be controlled, efforts to better understand the role that climate and other physical processes play in TSS generation are extremely 


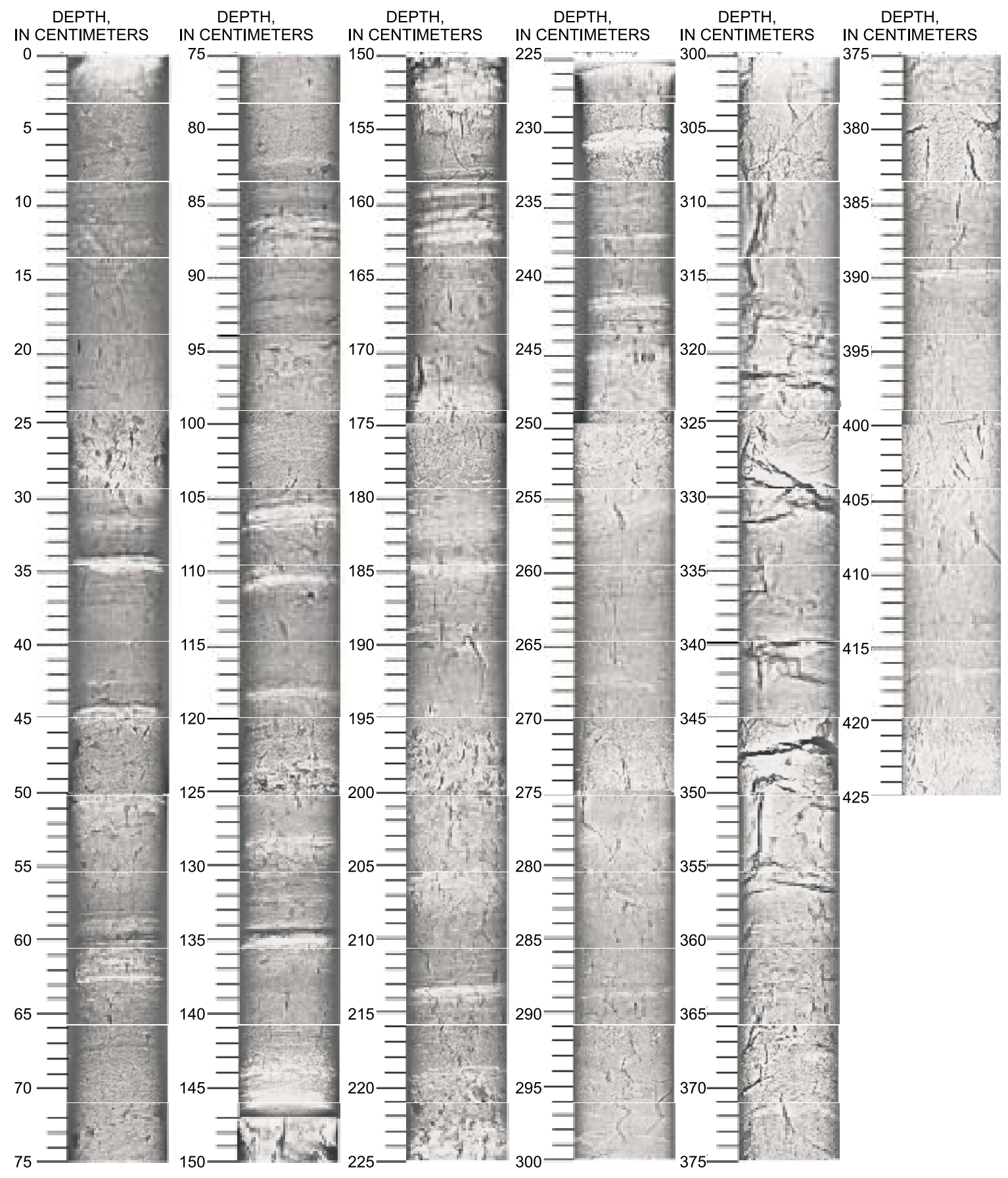

Figure 9. X-radiograph of 400-cm long sediment core from central Chesapeake Bay off Little Choptank River mouth, approximately $11 \mathrm{~m}$ water depth. Alternating light and dark colors represent climate and hydrologydriven changes in sedimentation, including changes in source, grain size, and biogeochemistry (From T. Cronin, U.S. Geological Survey and J. Hill, Maryland Geological Survey).

16 | EXECUTIVE SUMMARY 
important for ultimately improving probabilitybased model prediction of TSS loading from different sediment sources. Modeling sediment loads and secondary resuspension under various river discharge extremes and under specified wave and tidal conditions is one approach that might be considered. In addition to more data-model research efforts, "in-situ" management practices to reduce resuspended sediment should be investigated as a means to improve water clarity. Investigations could include, but not be limited to, breakwaters to reduce wave energy, planting of SAV beds, establishment of oyster beds, and protection and reestablishment of filter feeders.

\section{Sediment Deposition and Storage}

Unlike some estuaries that export sediment to the ocean, the Chesapeake Bay has been a sediment trap since sea-level rise flooded the former Susquehanna River Valley about 8,000 years ago. Sediment eroded from uplands and stream corridors, transported from the ocean, eroded from shorelines, and produced by biological processes has ultimately settled, been deposited, and buried by successive layers of sediment in the main stem of the bay and in depositional regions in the tributaries (Chapters 4 and 6). Over geological timescales, sediment in depositional areas may be eroded and redeposited; over shorter timescales, most sediment transported to the bay over the past few millennia is effectively stored and no longer contributes to suspended material. Understanding where, when, and how sediment settles in the bay system - that is, where the sediment "sinks" are and how sediment is resuspended prior to "permanent" burial-is a critical part of understanding the overall sediment budget in the bay. The important regions of sediment storage in the main stem of the bay, including the ETM zone, in stream channels, and in smaller tributaries are presented here.

Generally, coarse-grained sediment (sand) blankets Susquehanna Flats in the northernmost bay, the flanks of the bay, and much of the southern bay. Fine-grained sediments (silts and clays) blanket most of the deeper parts of the bay, including the main channel and the Tangier and Pocomoke Sound channels. Similar depth-related grain-size patterns are found in the major tidal tributaries and reflect the winnowing of fine-grained sediment from coarse-grained material and transport from shallow to deeper water. The greatest thicknesses of sediment that have accumulated since the bay formed consist of fine-grained silts and clays deposited in the main channel of the bay and channels in the larger tidal tributaries. However, as shown in figure 3 , sediment mass accumulation varies temporally, prior to and since colonization, and spatially in different regions of the bay system. In some regions of the modern Chesapeake Bay, no sediment is accumulating and these regions are undergoing net long-term erosion. Stratigraphic inconformities recognized in the geophysical and sedimentary record of the bay provide evidence for many periods of erosion over the past 8,000 years. These historical records indicate long-term shifts from net sediment accumulation to erosion and vice-versa over periods of hundreds to thousands of years. These long-term depositional and erosional patterns are caused by changes in estuarine circulation and other factors that are as yet unknown.

As discussed above, in the main stem bay, the ETM zone acts as a barrier for southward sediment transport of material introduced into the bay from the Susquehanna River and thus is an important site of sediment deposition. Similar sediment trapping and deposition occurs in the ETM zones of other tidal tributaries. In the area upstream of the ETM zone, in the tidal fresh zone, the contribution of sediment from watershed sources will be significant. Processes operating in the ETM zone can maintain areas of high sediment concentrations in the water column before settling. The high concentrations result in local degradation of water clarity. The location of the ETM zone in each tidal tributary depends on tributary-specific processes and will vary seasonally and yearly with freshwater flow from the watershed. Although the shortterm dynamics of sediment accumulation in the ETM zone are understood fairly well, long-term shifts in the position of the ETM zone and the timing of sediment transport out of the ETM zone are not well known. Downstream of the ETM zone, a greater contribution of sediment likely comes from local shoreline and marsh erosion, shallow water resuspension, and input from the bay.

Significant sediment is deposited and stored in river channels and floodplains adjacent to the bay. Most of this stored sediment in these regions probably is derived from upland erosion during extensive land clearance during the 18th and 19th centuries. This "legacy' sediment is not completely understood in terms of the volume of sediment in storage or what has reached the bay. Although sediment stored in river channels and tributaries will 
ultimately reach the bay (and thus this storage is temporary), it is likely that this transport will take years, decades, or even centuries, depending on future land uses and climatological and hydrological conditions. Therefore, management actions in the watershed may improve water-quality conditions in the estuary, but there may be substantial period of time before the results occur.

In summary, sediment accumulation varies spatially and temporally in response to many factors. On the basis of current understanding of sedimentary processes in the bay system, there will likely be a "lag time" of years to decades or longer between the implementation of a watershed bestmanagement practice, a reduction in sediment load to the Bay, and ultimate deposition of sediment in the bay bottom. This conclusion does not mean that sediment reduction in watershed regions will not have a positive effect on water quality. On the contrary, land-use changes can have a rapid effect on stream-water quality in the local area, and management strategies to restore light conditions in the tidal fresh zone above the ETM zone will be more dependent on sediment reductions from the watershed. What is uncertain, however, is the effect "downstream" of watershed management. Additional research into the lag times between historical land clearance and sediment loads would improve our understanding of how such future land-use changes will affect aquatic habitats.
List of Sediment Workgroup Members and Affiliation

\section{Lead editors}

Michael Langland, Hydrologist

U. S. Geological Survey

215 Limekiln Road

New Cumberland, PA 17070

Thomas M. Cronin

926A National Center

U.S. Geological Survey

Reston, VA 20192

\section{Lead reviewers}

Kenn Patison

Pa. Department of Environmental Protection

Division of Conservation Districts and Nutrient Management

P.O. Box 8465

Harrisburg, PA 17015-8464

Bruce Wardlaw

U.S. Geological Survey

Eastern Earth Surface Processes Team, MS 926A

12201 Sunrise Valley Drive

Reston, VA 20192

Editorial assistant

Kimberly N. Collini

Chesapeake Research Consortium

Chesapeake Bay Program Office

410 Severn Avenue, Suite 109

Annapolis, MD 21403 
Workgroup Members (alphabetical)

$\begin{array}{ll}\text { Name } & \text { Agency } \\ \text { Michael Bowman } & \text { Virginia Department of Conservation and Recreation } \\ \text { Owen Bricker* } & \text { U.S. Geological Survey } \\ \text { Grace Brush } & \text { Johns Hopkins University } \\ \text { Kimberly Collini } & \text { Chesapeake Research Consortium } \\ \text { Thomas Cronin* } & \text { U.S. Geological Survey } \\ \text { Lee Currey } & \text { Maryland Department of the Environment } \\ \text { Robert Edwards* } & \text { Susquehanna River Basin Commission } \\ \text { Allen Gellis* } & \text { U.S. Geological Survey } \\ \text { Normand Goulet } & \text { Northern Virginia Regional Commission } \\ \text { Jerry Griswold } & \text { Natural Resources Conservation Service } \\ \text { Amy Guise } & \text { U.S. Army Corps of Engineers } \\ \text { Jeffrey Halka* } & \text { Maryland Geological Survey } \\ \text { Julie Herman* } & \text { Virginia Institute of Marine Science } \\ \text { Lee Hill } & \text { Virginia Department of Conservation and Recreation } \\ \text { Clifford Hupp* } & \text { U.S. Geological Survey } \\ \text { Martha Jonas } & \text { U.S. Army Corps of Engineers } \\ \text { Timothy Karikari } & \text { District of Columbia Department of Health } \\ \text { Jurate Landwehr } & \text { U.S. Geological Survey } \\ \text { Michael Langland* } & \text { U.S. Geological Survey } \\ \text { Lewis Linker* } & \text { U.S. Environmental Protection Agency } \\ \text { Matthew Monroe } & \text { West Virginia Department of Agriculture } \\ \text { Kenn Patison* } & \text { Pennsylvania Department of Environmental Protection } \\ \text { Frank Payer } & \text { Pennsylvania Department of Environmental Protection } \\ \text { Scott Phillips* } & \text { U.S. Geological Survey } \\ \text { Brian Rustia } & \text { Metropolitan Washington Council of Governments } \\ \text { Nancy Rybicki } & \text { U.S. Geological Survey } \\ \text { Lawrence Sanford* } & \text { University of Maryland, Center for Environmental Science } \\ \text { Gregory Schwarz* } & \text { U.S. Geological Survey } \\ \text { Gary Shenk } & \text { U.S. Environmental Protection Agency } \\ \text { Kelly Shenk } & \text { U.S. Environmental Protection Agency } \\ \text { Sean Smith* } & \text { Maryland Department of Natural Resources } \\ \text { Steven Stewart* } & \text { Baltimore Co. Dept. of Environmental Protection \& Resource } \\ & \text { U.S. Environmental Protection Agency } \\ \text { Jeffrey Sweeney } & \text { U.S. Geological Survey } \\ \text { Debra Willard* } & \text { to the report. } \\ \text { * indicates contributing author } & \\ \text { With additional contributions } & \text { from non-work group members. } \\ & \end{array}$




\section{Acknowledgments}

This report relied heavily on contributions from cited literature, contributed unpublished work, and information from presentations at Sediment Workgroup meetings. The authors wish to express their gratitude to workgroup members who did not contribute to "authorship" explicitly, and also to nonmembers whose contributions aided in the completion of the report. Dhiren Khona, Cheryl Vann, Wayne Newell, Nancy Rybicki, Jurate Landwehr, Casey Saenger, all from the U.S. Geological Survey, Charles Hobbs of the Virginia Institute of Marine Science, James Titus, Richard Batiuk, Gary Shenk and Lewis Linker of the U.S. Environmental Protection Agency, David Jasinski of the University of Maryland, Grace Brush of the Johns Hopkins University, Christopher Spaur of the U.S. Army Corps of Engineers, and Thomas Beauduy of the Susquehanna River Basin Commission. Finally a special acknowledgement to Thomas Simpson of University of Maryland, chair of the Nutrient Subcommittee for his involvement in the creation of the Sediment Workgroup and providing guidance and goals from which to work from.
ABSTRACT

The Chesapeake Bay, the Nation's largest estuary, has been degraded because of diminished water quality, loss of habitat, and over-harvesting of living resources. Consequently, the bay was listed as an impaired water body due to excess nutrients and sediment. The Chesapeake Bay Program (CBP), a multi-jurisdictional partnership, completed an agreement called "Chesapeake 2000" that revises and establishes new restoration goals through 2010 in the bay and its watershed. The goal of this commitment is the removal of the bay from the list of impaired waterbodies by the year 2010. The CBP is committed to developing sediment and nutrient allocations for major basins within the bay watershed and to the process of examining new and innovative management plans in the estuary itself and along the coastal zones of the bay. However, additional information is required on the sources, transport, and deposition of sediment that affect water clarity. Because the information and data on sediment processes in the bay were not readily accessible to the CBP or to state, and local managers, a Sediment Workgroup (SWGP) was created in 2001.

The primary objective of this report, therefore, is to provide a review of the literature on the sources, transport, and delivery of sediment in Chesapeake Bay and its watershed with discussion of potential implications for various management alternatives. The authors of the report have extracted, discussed, and summarized the important aspects of sediment and sedimentation that are most relevant to the $\mathrm{CBP}$ and other sediment related-issues with which resources managers are involved. This report summarizes the most relevant studies concerning sediment sources, transport and deposition in the watershed and estuary, sediments and relation to water clarity, and provides an extensive list of references for those wanting more information. 


\section{CHAPTER 1. INTRODUCTION}

\section{by Thomas Cronin and Michael Langland}

The Chesapeake Bay is one of the largest and most productive estuarine systems in the world. The Chesapeake Bay "main stem," defined by tidal zones, is approximately $195 \mathrm{mi}$ long and 3.5 to $35 \mathrm{mi}$ wide, and has a surface area of nearly $4,400 \mathrm{mi}^{2}$. The main stem is entirely within Maryland and Virginia. Nearly 50 rivers, with thousands of tributary streams and creeks, drain the approximately $64,000 \mathrm{mi}^{2}$ forming the Chesapeake Bay Basin. The basin contains more than 150,000 stream miles in the District of Columbia and parts of six states: New York, Pennsylvania, Maryland, Virginia, West Virginia, and Delaware (fig. 1.1). Nine rivers, including the Susquehanna, Patuxent, Potomac, Rappahannock, York (consists of the Mattaponi and Pamunkey), James, Appomattox, and Choptank (fig. 1.1), contribute approximately 90 percent of the bay's mean annual freshwater inflow of $69,800 \mathrm{ft}^{3} / \mathrm{s}$ (U.S. Army Corps of Engineers, 1977). The Susquehanna River, the largest river entering the bay, drains nearly 43 percent of the $64,000-\mathrm{mi}^{2}$ basin and normally contributes about 50 percent of the freshwater reaching the bay.

\section{Background}

The Chesapeake Bay has been degraded because of water-quality problems, loss of habitat, and over-harvesting of living resources. The Chesapeake Bay was listed as an impaired water body in 2000 under the Clean Water Act because of excess nutrients and sediment and it must meet Federal regulatory water-quality standards by 2010. The Chesapeake Bay Program (CBP), a multiagency partnership, completed Chesapeake 2000, a new agreement that revises and establishes restoration goals for the next 10 years in the bay and its watershed. In the agreement, improving water quality is identified as the most critical element in the overall protection and restoration of the Chesapeake Bay and its tributaries. Part of the degradation in water quality is caused by excess sediment in the water column and its adverse effects on the living resources and associated habitat.

During the last 30 years, excess sediment has caused significant reductions in submerged aquatic vegetation (SAV); covered filter-feeding benthic organisms, thereby affecting their vitality; and delivered chemical constituents and pathogens associated with sediment to the bay, affecting fisheries and other living resources. Water clarity and sediment problems are not unique to the estuary and its tidal tributaries; many stream habitats in the watershed also are affected by these problems.

\section{Sediment Workgroup}

To establish and implement sediment-reduction measures and to improve water-quality modeling efforts to understand the potential effect of management policies, the CBP required information on the sources, transport, and deposition of sediment that is affecting water clarity. Because the knowledge and data on sediment processes were not readily accessible to the CBP or to state and local managers, a Sediment Workgroup (SWGP) was created in 2001. The SWGP consists of Federal, State, and local government scientists and managers and university researchers with various backgrounds and expertise relevant to sedimentary processes.

Since its inception, the SWGP convened monthly to examine sediment-related issues, to hear invited speakers from the scientific community, to prioritize research needs, and to develop a set of management implications based on the SWGP findings. In the early stages of the SWGP efforts, a provisional outline of a summary report was decided upon and various workgroup members were charged with writing chapters or parts of chapters on topics of their expertise. Because of the inherent interdisciplinary nature of sedimentary processes in the bay and its watershed, expertise in hydrology, geology, biology, physical oceanography, environmental science, meteorology and climatology, among other topics, was required. Consequently, the meetings among SWGP members fostered a unique, though sometimes challenging, exchange of ideas on sedimentation from a wide variety of perspectives. To our knowledge, such an interdisciplinary investigation of sedimentary processes has never before been undertaken for Chesapeake Bay.

\section{$\underline{\text { Report Objectives and Scope }}$}

The primary objective of this report is to provide a review of the literature on the sources, transport, and delivery of sediment in Chesapeake Bay and its watershed with discussion of the potential implications for management actions. Because the Chesapeake Bay has been one of the most intensely studied estuaries over the past 50 years, it would 


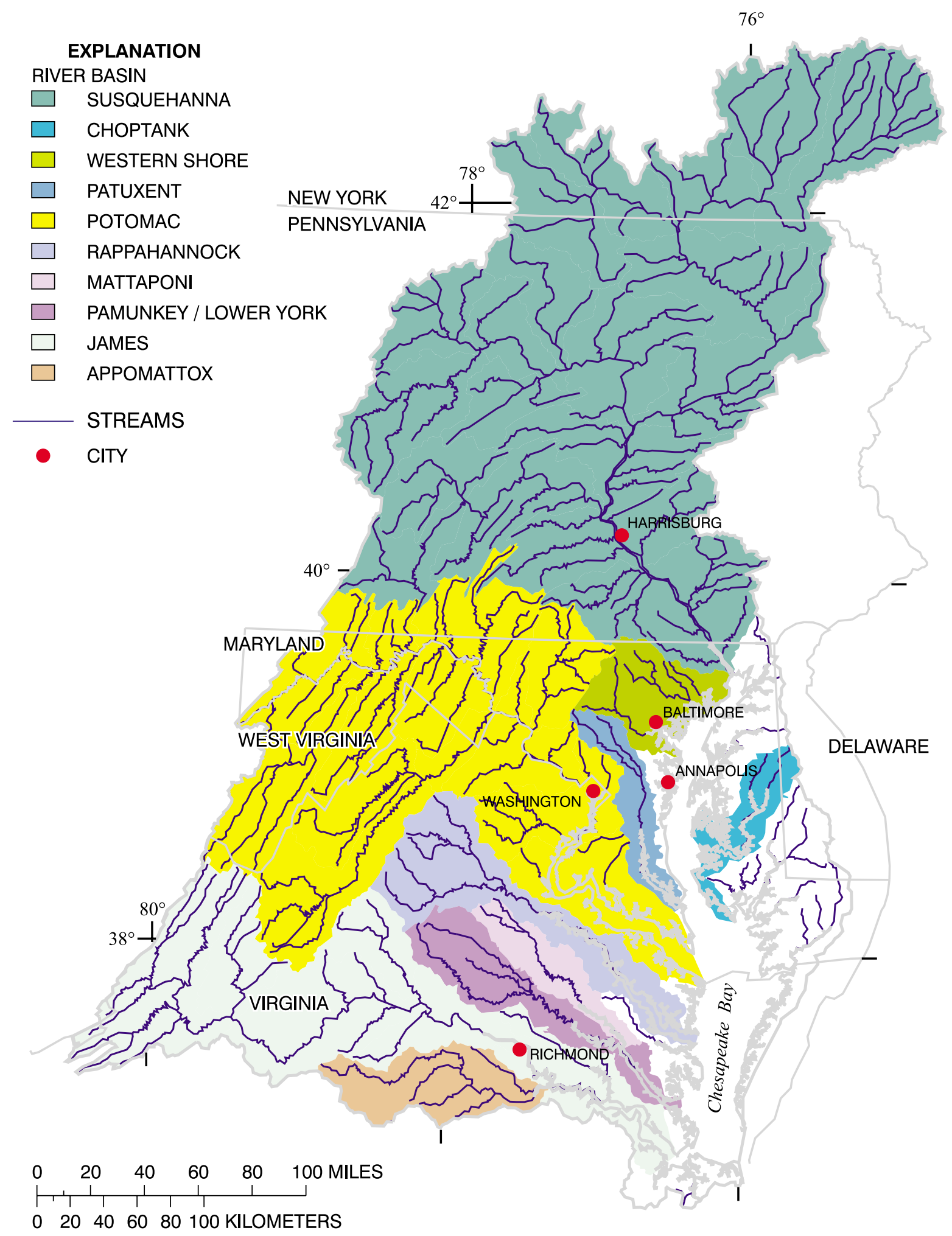

Figure 1.1. Location of Chesapeake Bay watershed and estuary. 
be impossible in a single document to fully review and critically discuss all aspects of sediment patterns and processes in the region. Therefore, the authors of the report have extracted, discussed, and summarized important aspects of sediment and sedimentation that are most relevant to the CBP and other sediment-related issues with which resources managers are involved. Many of these most important aspects are underlined throughout the report. In producing this document, the SWGP members drew on peer-reviewed published literature, research in progress, the opinions of invited experts, and certain "grey" literature reports containing valuable information. The extensive bibliography in this report serves as a resource for those readers seeking more information on methodology and results.

The writing and editing process of the final text involved a large degree of subjectivity in terms of the scope and treatment of each topic. Because the SWGP was created with the mandate by the $\mathrm{CBP}$ to help provide input to the management community, the report does not provide a comprehensive review of all available literature, and gaps exist in the coverage of certain topics. Nonetheless, the report summarizes those studies most relevant to concerns about sediment and water clarity and provides references for those wanting more information.

Following the Executive Summary, there are chapters on Watershed Sediment Sources, Transport, and Deposition; Estuarine Sediment Sources, Transport, Deposition; and Sedimentation, Integrated Approaches to Sediment (sediment budgets and modeling), and a Bibliography.

\section{Terminology for Sediment and Total Suspended Solids}

Sediment is solid material transported and deposited by wind, water, or ice, chemically precipitated from solution, or secreted by organisms. In estuaries like Chesapeake Bay, sediment consists largely of water-borne detrital material (pebbles, sand, mud), including varying amounts of particulate organic material. Over time, sediment settles to the bottom and accumulates to form clastic rocks (conglomerate, sandstone, shale). However, most sediment deposited during the past 8,000 years in Chesapeake Bay is still unconsolidated and those sediments deposited during the last few centuries still contain more than 50-percent water content in pore spaces between sedimentary parti- cles. The organic fraction of sediment collected from the bottom of Chesapeake Bay consists of 1-3 percent organic material, the rest consists of inorganic mineral material and varying amounts of shell material.

Geologists refer to sediments in terms of grain size, texture, mineralogy, and other characteristics. Throughout this report, an important distinction is made between fine-grained sediment, which refers to the clay- (less than $1 / 256-\mathrm{mm}$ diameter) and silt- (1/256- to $1 / 16$-mm diameter) sized fractions, and coarse-grained sediment, which refers to the sand- (1/16 to 2-mm diameter) and gravel- (2 to 64-mm diameter) sized fractions. This fine/coarse distinction is important because most coarse material is transported along the bottom of rivers and the bay and has little effect on light penetration. In contrast, fine-grained sediment commonly is found in suspension and variably blocks light penetration depending on its abundance, grain-size distribution, and degree of aggregation (flocculation).

Hydrologists commonly refer to sediment using terminology that reflects their interest in the total amount of suspended material in a water sample. Total suspended solids (TSS) and suspended sediment concentration (SSC) are two measurements of the concentration of suspended solids in a water sample (Gray and others, 2000). Both measurements usually are given in milligrams per liter. SSC is measured as the dry weight of total sediment in a sample divided by the amount of water-sediment mixture in the sample. TSS can be measured by several methods. It usually is measured by taking a subsample of known volume from the original suspended-sediment sample, drying the sediment, and dividing by the known volume. Most TSS measurements cited in this report refer to data obtained with this method.

\section{TSS Variability}

Data from CBP monitoring sites and the published literature show that the relative proportion of inorganic and organic components of TSS vary seasonally and interannually, due mainly to variability in freshwater inflow, and vary spatially, depending on proximity to shoreline, oceanic, and riverine sources of inorganic sediment. Gallegos and Moore (as cited in Batiuk and others, 2000) used CBP data from 1994 to 1996 to show that when TSS concentrations are high (greater than $50 \mathrm{mg} / \mathrm{L}$ ), the organic component of TSS consti- 
tutes an average of 18 percent of TSS; and when TSS concentrations are low to moderate (less than $50 \mathrm{mg} / \mathrm{L}$ ), the organic component varies from 0 to 90 percent. The organic component of TSS was dominant (greater than 50 percent) only when TSS concentrations were low (less than 10-15 mg/L).

Annual variability in TSS in the bay and its tributaries can be illustrated by plotting 15 years of monthly TSS data from two CBP stations in the bay. TSS data from 1985 to 2000 for surface and deep water at station CB4.4 in the central main stem bay and for surface $(0.5 \mathrm{~m})$ and near-surface (2-4 m) depths in Pocomoke Sound are shown in figure 1.2. These data show the following features of TSS variability:

- On average, surface TSS values are higher (10 to greater than $50 \mathrm{mg} / \mathrm{L}$ ) at the Pocomoke Sound EE3.3 site compared to the main stem CB4.4 site (4 to $10 \mathrm{mg} / \mathrm{L}$ ).

- Deep-water TSS maxima occur in winter at the CB4.4 monitoring site, reaching greater than $80 \mathrm{mg} / \mathrm{L}$ during some years, but only 20 to $40 \mathrm{mg} / \mathrm{L}$ during others.

- Summer deep-water TSS minima are relatively invariant from year to year; these features are observed in other TSS records from the central main stem bay.

- Surface $(0.5 \mathrm{~m})$ and deep-water $(24.5-31 \mathrm{~m})$ TSS records are not correlated with one another at the CB4.4 site

- Surface $(0.5 \mathrm{~m})$ and near-surface (2 to $4 \mathrm{~m})$ TSS records at the EE3.3 site generally are similar to each other.

Spatial and seasonal variability in TSS is shown in figure 1.3 where CBP data for winter and spring seasons are mapped for relatively wet (1993) and dry (1992) years. These maps, prepared by D. Khona (University of Florida and USGS) and T. M. Cronin (USGS), show high winter concentrations of TSS in 1992 near the mouth of the bay, reflecting ocean-source sediments. High TSS concentrations were observed in the northern bay, and in the larger tributaries, especially during 1993, reflecting high turbidity in the estuarine turbidity maximum zones. Such spatial analyses are useful to identify regions of relatively high TSS (20 to greater than $80 \mathrm{mg} / \mathrm{L}$ ), which, if the organic to inorganic ratios reported in Batiuk and others (2000) hold, represent regions where the inorganic component of TSS is high (greater than 70 percent).
The evidence that the major component of TSS is inorganic mineral sediment at moderate to high TSS values, and the fact that TSS is a major cause of light attenuation, has significant implications for water quality management in general, and efforts to improve water clarity in particular. These facts imply reducing chlorophyll $a$ and the organic component of TSS through nutrient reduction will only partially address the causes of diminished water clarity. To fully address the issue of water clarity in Chesapeake Bay, detrital sediment-that is, "suspended solids" introduced by the influx of mineral clays, silts, and sand-sized particles into aquatic systems, must also be taken into account. Therefore, most of the current report focuses on processes and patterns of detrital sediment erosion, deposition, and re-suspension in Chesapeake Bay, its tidal tributaries, and its watershed that influence TSS concentrations and, ultimately, SAV and critical habitats.

In addition to sediment introduced from external sources, and the volatile organic component of TSS, particulate material also is produced in the water column and on the bay bottom through the biological secretion of hard skeletons by diatoms (siliceous), dinoflagellates (organicwalled cysts), and calcareous organisms (foraminifera, ostracodes, mollusks). These "biogenic" components of sediment range in size from a few microns to greater than $1 \mathrm{~mm}$ in diameter. The abundance of biogenic material is influenced strongly by nutrient influx and productivity. Regardless of their origin, once shell-producing organisms die, their skeletons behave like other fine-grained particulate material and settle through the water column. They either become incorporated into sediment accumulating on the bay bottom or, like inorganic clays and silts, become subject to resuspension and transport by tides and currents. Thus, biogenic material contributing to TSS and diminished water clarity also is discussed.

The degree of suspended particle aggregation is also important for many aspects of suspended-particle dynamics. Studies (Fugate and Friedrichs, 2002; Sanford and Halka, 1993; Sanford and others, 2001; Schubel, 1971) have separated Chesapeake Bay suspended sediment into two populations: a relatively unaggregated, slowly settling background suspension, and a highly aggregated, rapidly settling population that is maintained in the water column by resuspension. Aggregated particles are considerably larger and 

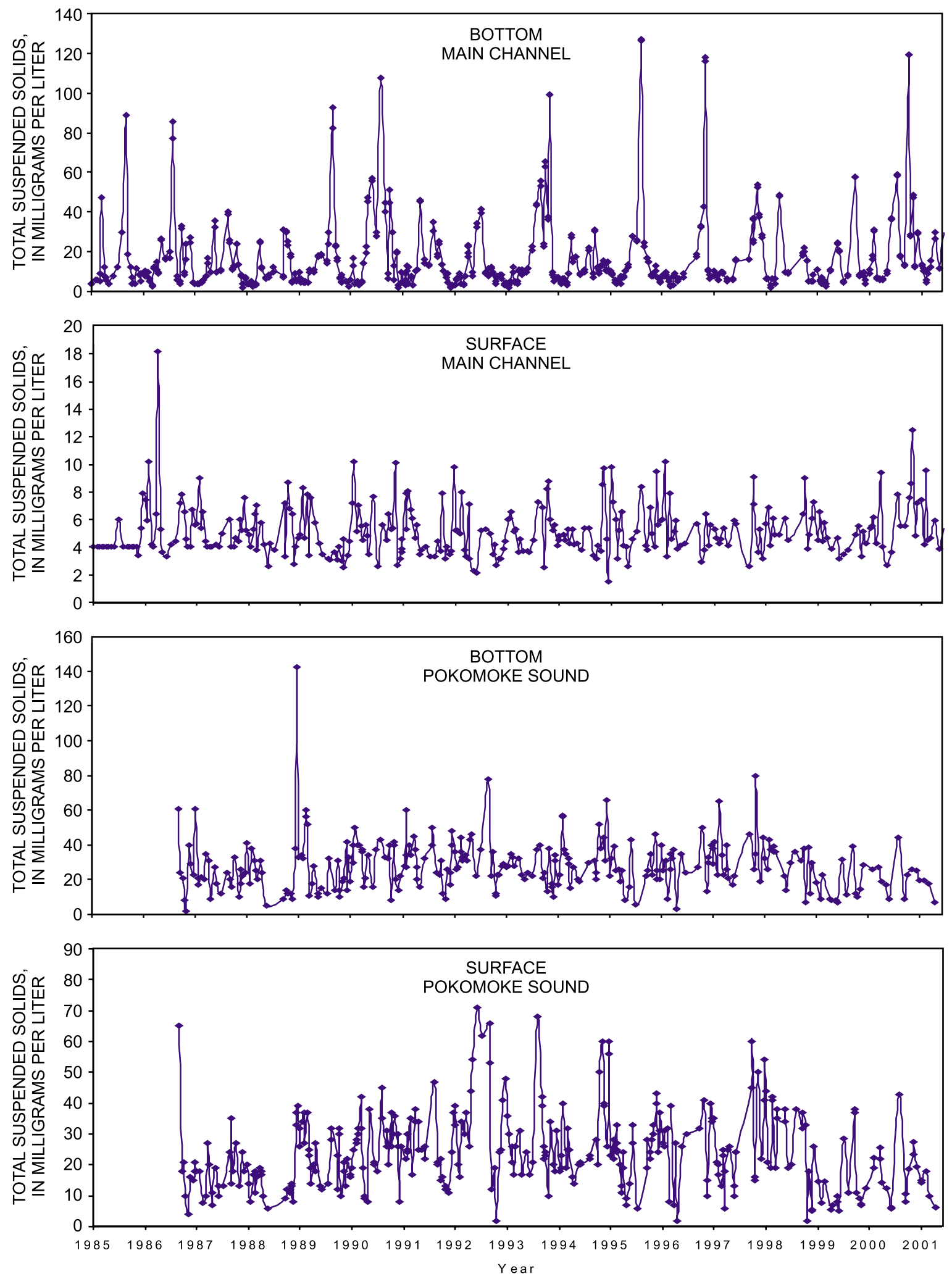

Figure 1.2. Mean monthly concentrations of total suspended solids (TSS) at two CBP monitoring sites for shallow $(0.5 \mathrm{~m})$, near-surface $(2-4 \mathrm{~m})$, and deep $(24.5-31 \mathrm{~m})$ water depth. (Plots show interannual and seasonal variability in TSS.) 

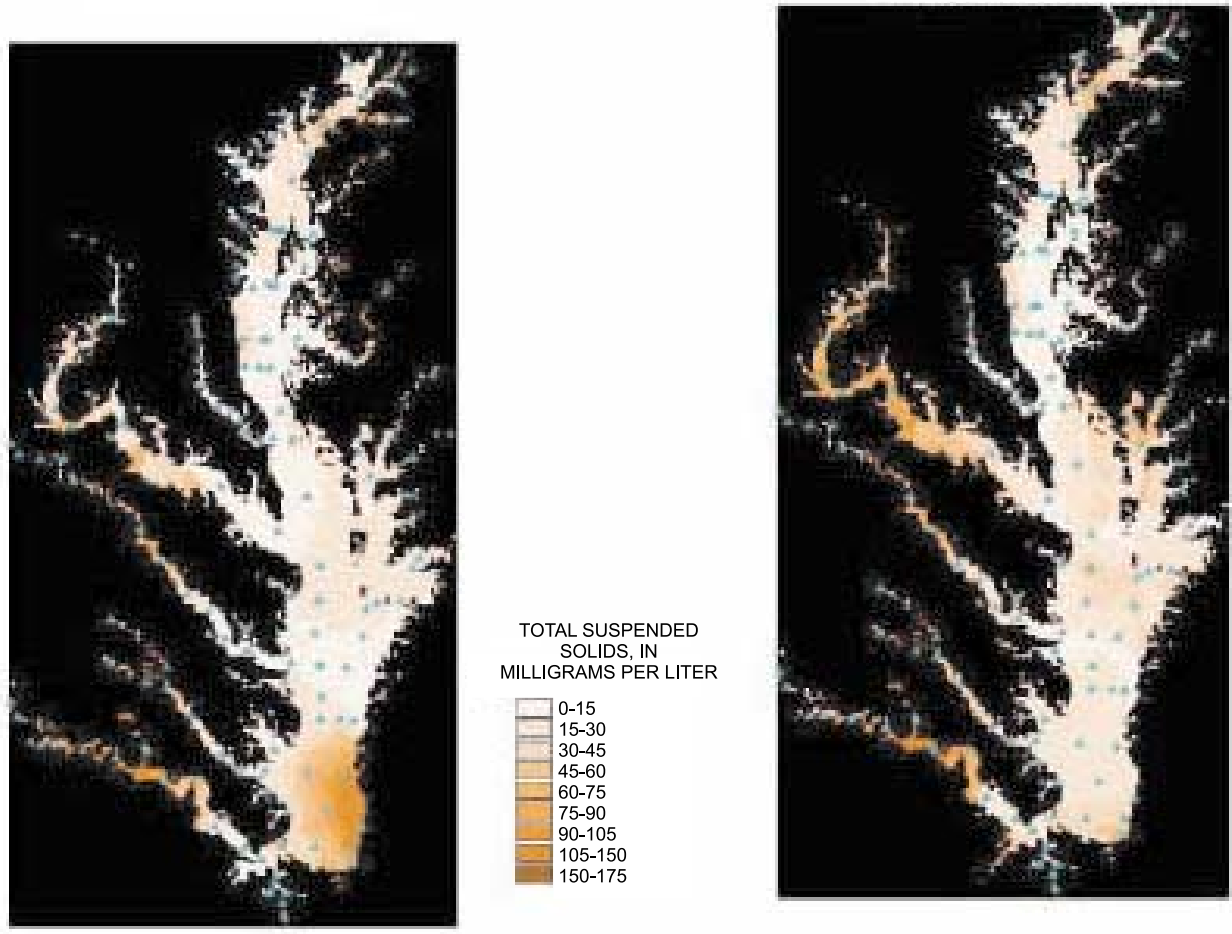

TOTAL SUSPENDED SOLIDS, IN

MILLIGRAMS PER LITER

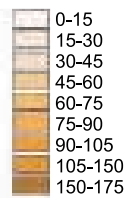

MILLIGRAMS PER LITER

SPRING 1992
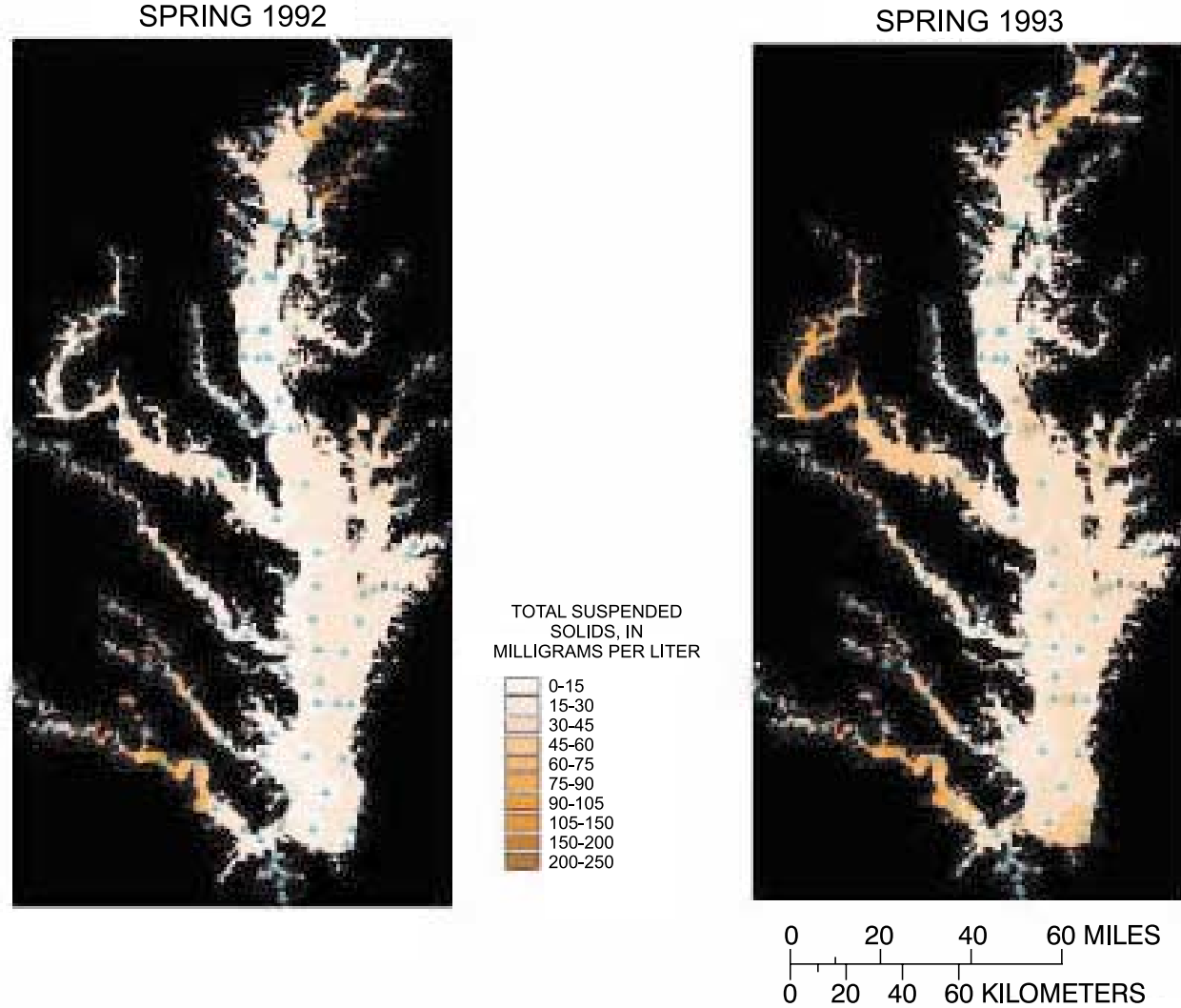

TOTAL SUSPENDED SOLIDS, IN MILLIGRAMS PER LITER

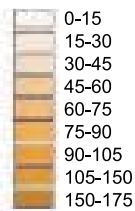

Figure 1.3. Concentrations of total suspended solids in winter and spring, 1992 and 1993. (Total suspended solids data from Chesapeake Bay Program, Annapolis, Md., Chesapeake Information Management System.) 
settle faster than their constituent sediment particles. They are commonly made up of a broad distribution of particle sizes and chemical compositions, and can be strongly influenced by both biological and physical processes (Hill and others, 2001; Kranck and others, 1993; Schubel, 1971; Zabawa, 1978). Little is known about aggregation/disaggregation dynamics in the bay, but it is known that large aggregates are less efficient at blocking light than small aggregates or unaggregated fine sediment particles (fig. 1.4) (Gardner and others, 1985; Sanford and others, 2001; Zaneveld and others, 1979).

A wide variety of methods have been used to study sediments and sedimentary processes in Chesapeake Bay. These include bathymetric surveys, geophysical surveys of accumulated sediment on the bay floor; Light Detection and Ranging (LIDAR) surveys of shorelines; Acoustic Doppler Current Profiler (ADCP) surveys; satellite imagery; sediment core analyses; sedimentary geochemistry; short-lived radioisotopic analyses of mass accumulation rates; geochemical tracers of sediment source; photogrammetric and cartographic analysis of coasts; mineralogical analysis of sediment; and analysis of TSS concentration and composition. Each study had its own objectives, which in most cases were not directly concerned with issues of water clarity and SAV health. The reader is urged to consult the original literature for details of methodologies and conclusions.

\section{TSS, Light, and SAV}

The amount of light reaching SAV in shallow waters of Chesapeake Bay is influenced by many factors. The most important properties in the water column are water color, and concentrations of TSS and chlorophyll $a$. Water column TSS consists of organic material, referred to as total volatile suspended solids (TVSS) and inorganic 'mineral' matter. Because TVSS consists of organic components of water (phytoplankton, heterotrophic plankton, bacteria, and particulate organic material), its relative contribution to TSS is related to nutrient concentrations and algal abundance. The inorganic mineral component of TSS generally consists of fine-grained silts and clays and the abundance of mineral sediment is related to various physical processes such as river discharge, tidal and wave erosion, estuarine circulation, and currents, as well as geology, geomorphology, land-use, and other factors.

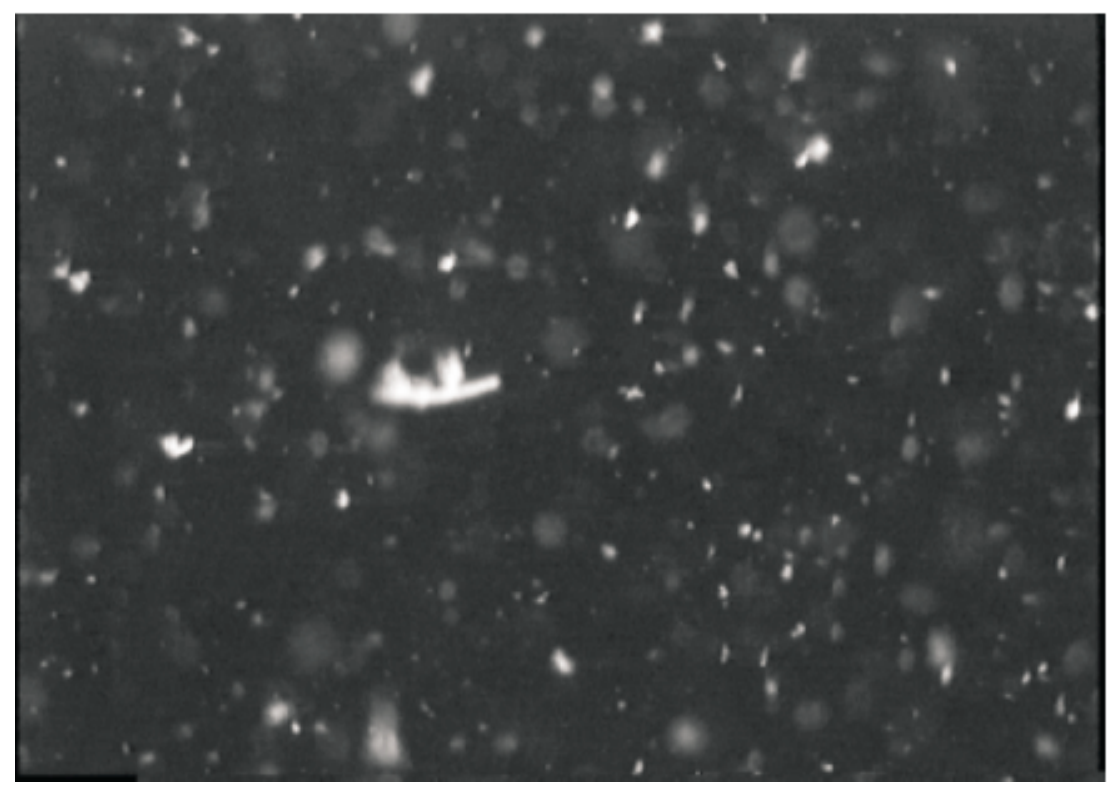

Figure 1.4. Photograph of suspended fine sediment flocs from a site in upper Chesapeake Bay during October 2002. The image was obtained with a particleimaging system consisting of a low-light video camera and a collimated light beam. The width of the image is approximately 1 centimeter and the depth of field is approximately 1 centimeter. Flocs and particles smaller than 0.003 centimeter (30 microns) are not resolved (photo credit, Larry Sanford, University of Maryland, Center for Environmental Science, 2003). 
The organic and inorganic components of TSS vary in their relative proportion spatially and temporally in complex and only partially understood ways. In general, at typical measured levels of TSS (less than $50 \mathrm{mg} / \mathrm{L}$ ), more than 50 percent (usually 60 to greater than 90 percent) of the TSS loading consists of inorganic material; at relatively high TSS concentrations, TVSS approaches an average of about 18 percent of the TSS. Only at relatively low TSS values (less than 10-15 mg/L) does TVSS consist of more than 50 percent of the TSS. These patterns suggest that the inorganic fraction of TSS, i.e., fine-grained sediment ultimately derived from riverine, shoreline, and oceanic sources, and reintroduced into the water column through resuspension of bottom sediment, plays a major role in light attenuation.

In addition to TSS and chlorophyll $a$ in the water column, epiphytes and other organic and inorganic material accumulated on the SAV leaf surfaces decrease the amount of light penetration necessary for photosynthesis. Because epiphyte abundance on SAV is itself influenced by nutrient loading and algal abundance, and the amount of inorganic material settling on leaf surfaces is influ- enced by mineral sediment in the water column, light-attenuation by material settling on SAV surfaces is related closely to processes in the water column.

In summary, the literature on TSS, light, and SAV relations indicates complex physical and biological processes governing inorganic and organic sediment production, transport, and deposition. The physical processes that govern the introduction, transport, re-suspension, and deposition of inorganic sediment are distinct from biological production of particulate material driven by nutrient concentrations and primary production. However, these processes are related to one another such that efforts by water-resource managers to reduce nutrient loadings might also help to improve water clarity by affecting the levels of particulate material in the water column and algal epiphyte growth on SAV. Future research programs and management strategies to control chlorophyll $a$ and nutrient loadings could be coordinated with efforts aimed at reducing the concentration of mineral sediment and thus take into account the cumulative impacts of organic and inorganic material on light attenuation. 


\section{CHAPTER 2. WATERSHED SEDIMENT SOURCES}

\author{
by Allen Gellis, ${ }^{1}$ Sean Smith, ${ }^{2}$ \\ and Steven Stewart ${ }^{3}$
}

Watershed sediment sources can be separated into sediment originating in upland regions, sediment from urban areas, and sediment eroded from channel corridors. In this section, these subjects are briefly discussed, although it should be emphasized that the processes controlling sediment flux in the watershed are strongly interrelated. Additional discussion of sediment sources and transport is given in Chapter 7 in the context of developing quantitative sediment budgets.

\section{Upland Sediment Sources}

Upland sediment refers to material eroded from hillslope surface areas adjacent to stream corridors. Upland regions include forests, rangeland, agriculture (cropland and pasture), rural, and urban areas. Land-surface characteristics strongly influence the sediment flux from a particular watershed region, and thus it is important to briefly discuss sediment removal from upland surfaces.

Soil from land surfaces is eroded through detachment of material by either water (raindrop impact and runoff) or wind (eolian). Soil erosion by water is the dominant transport mechanism from upland sources and commonly is expressed quantitatively and incorporated into a sediment budget (Leopold and others, 1966; Dietrich and Dunne, 1978; Swanson and others, 1982; Gellis and others, 2001). Sediment removed and transported from upland sources typically is reported as a yield over time (tons per square mile per year or square kilometers per year).

In a classic paper on sediment derived from land surfaces, Wolman and Shick (1967) discussed post-colonial land-use change in the northeastern United States and its effect on sediment yield (fig. 2.1). Wolman and Shick proposed that in the late 1800s, when forestland was converted to agriculture, sediment yields increased from 100 tons $\mathrm{mi}^{-2}$ ( 35 metric tons $\mathrm{km}^{-2}$ ) to 600 tons $\mathrm{mi}^{-2}$ (210 metric tons $\mathrm{km}^{-2}$ ). During the 1960s, many

\footnotetext{
${ }^{1}$ U.S. Geological Survey.

${ }^{2}$ Maryland Department of Natural Resources.

${ }^{3}$ Baltimore County Department of Environmental Protection and Resource Management.
}

rural areas near cities became urbanized resulting in another increase in sediment from construction activity when sediment yields exceeded 2,000 tons $\mathrm{mi}^{-2}\left(35,000\right.$ metric tons $\left.\mathrm{km}^{-2}\right)$.

Several other studies provide estimates of sediment yields from land surfaces in the Chesapeake Bay watershed region. Guy and Ferguson (1962) reported yields of 25,000 to 50,000 tons $\mathrm{mi}^{-2}$ (8,750 to 17,500 metric tons $\left.\mathrm{km}^{-2}\right)$ from construction areas near Washington D.C. Roberts and Pierce (1976) proposed that the Patuxent River more than doubled its sediment yield after urbanization (983 tons $\mathrm{mi}^{-2} ; 344$ metric tons $\mathrm{km}^{-2}$ compared to pre-urbanization values of 408 tons $\mathrm{mi}^{-2}$; 143 metric tons $\mathrm{km}^{-2}$ ). In a detailed study of the Western Run Basin $\left(60 \mathrm{mi}^{2}\right)$ north of Baltimore, Costa (1975) estimated that land clearing for agriculture caused 34 percent of eroded sediment to be transported through the basin and 66 percent was retained in storage. Of the 66 percent of sediment in storage, 21 percent was deposited on floodplains and 79 percent was retained on hillslopes as colluvium and sheetwash deposits. Costa found that channels initially responded to the increased sediment load by aggrading. As sediment loads decreased as a result of decreasing agricultural practices and soil conservation, stream channels began to incise and scour of stream channels became an important source of sediment.

Brown and others (1988) used ${ }^{10} \mathrm{Be}$ (an isotope of beryllium) to estimate the erosion in 48 basins of the eastern United States, including 10 basins that drain to the Chesapeake Bay. ${ }^{10} \mathrm{Be}$ is a cosmogenic isotope produced in the atmosphere and deposited on the earth's surface during precipitation. Interpretations of basinwide erosion were based on an erosion index defined as the ratio of the amount of ${ }^{10} \mathrm{Be}$ leaving a basin to the amount deposited on it. The highest rates of erosion were observed in the Piedmont streams, and the lowest rates were observed in Coastal Plain streams, due to differences in land use and stream gradients. The Piedmont has had two centuries of farming that disturbed the topsoil and led to high erosion of sediment with higher concentrations of ${ }^{10} \mathrm{Be}$. Annual pre-colonization sediment yields for the Piedmont were estimated to be 34.3 tons $\mathrm{mi}^{-2}$ (12 metric tons $\mathrm{km}^{-2}$ ), a value that closely matches values from modern undisturbed basin sediment yields (Brown and others, 1988). 


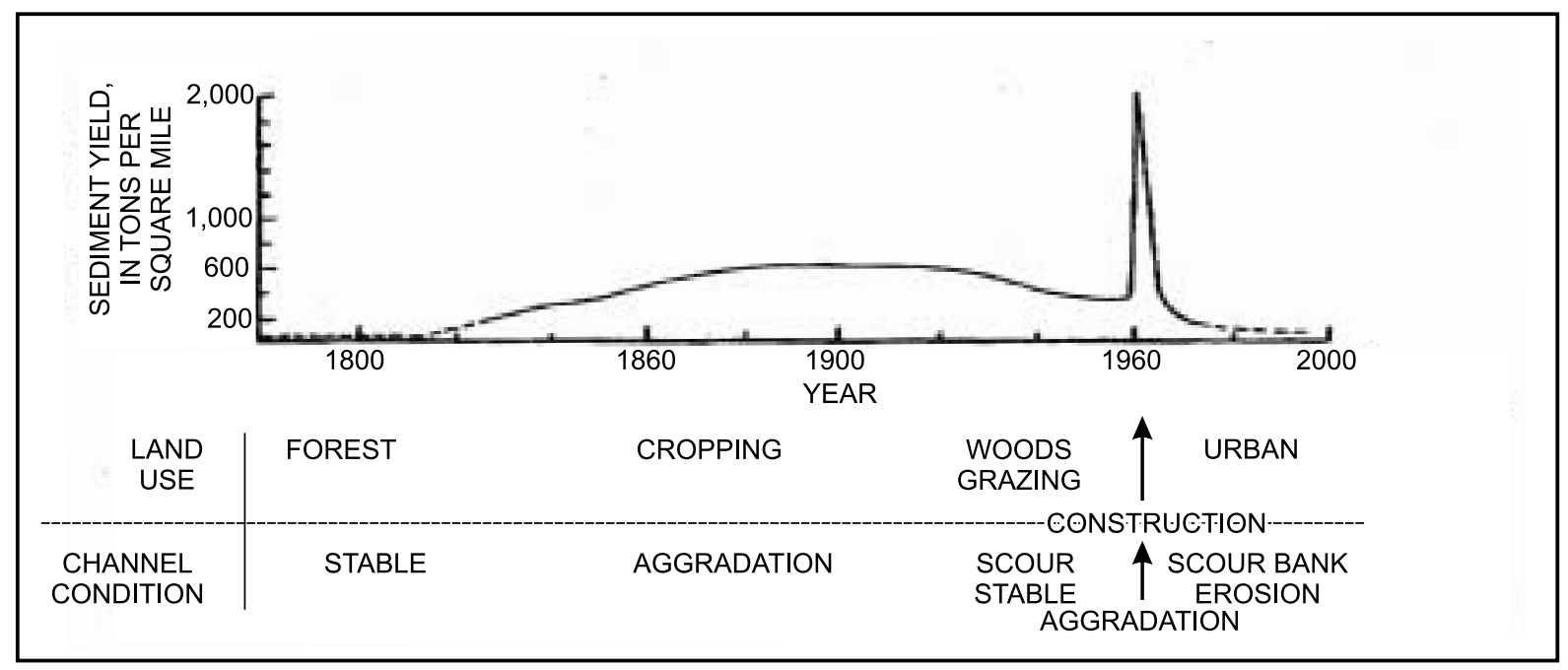

Figure 2.1. Land-use history and sediment yield from the Potomac River Basin in the northeastern United States, from the late 1700s to the 1960s, projected to approximately 2000 (from Wolman and Shick, 1967).

Coal-mining activities also can contribute fine particles to fluvial systems and thus can increase natural sediment yields 30 to 40 times above background levels (Biesecker and others, 1968). Since 1907, coal separation by wet methods carried fine waste to the nearest rivers, contributing between 12 and 18 percent of the total fine sediment load (Biesecker and others, 1968).

Reed and Hainly (1989) compared the effects of coal mining on sediment yield in mined and unmined areas of Pennsylvania between 1978 and 1982. Sediment yields in an unmined basin dominated by agriculture were 0.48 ton acre ${ }^{-1}$ (1.1 metric tons hectare $\left.{ }^{-1}\right)$ but only 0.0036 ton acre $e^{-1}$ $\left(0.0081\right.$ metric ton hectare $\left.{ }^{-1}\right)$ in a forested basin. A mined area had a sediment yield of 5.5 tons $\operatorname{acre}^{-1}\left(12.3\right.$ metric tons hectare $\left.{ }^{-1}\right)$. Installation of a sediment-retention pond below the mined area reduced the sediment yield to 0.14 ton acre ${ }^{-1}$ $\left(0.31\right.$ metric ton hectare $\left.{ }^{-1}\right)$. In two other mined areas, sediment yield below sediment-retention ponds was 0.19 and 0.30 ton acre ${ }^{-1}$, respectively $\left(0.42\right.$ and 0.67 metric ton hectare $\left.{ }^{-1}\right)$. Reclamation of vegetation on the two mined sites reduced sediment yield to 0.037 ton acre ${ }^{-1}$ (0.083 metric ton hectare $\left.^{-1}\right)$ and 1.0 ton acre ${ }^{-1}$ (2.24 metric tons hectare $\left.^{-1}\right)$. Since the 1960s, sediment discharge has been decreasing in many rivers in Pennsylvania because of decreased mine activity and stricter regulations (Williams and Reed, 1972).

In a study of sediment yields for the Susquehanna River Basin, Williams and Reed (1972) noted that the range in sediment yields was related to topography (slope), geology, glacial history, and land use. Soils derived from sandstones in the Appalachian Plateau Physiographic Province, with its extensive forest cover, had low sediment yields. In mined areas of the Appalachian Plateau, sediment yields were surprisingly low. Internal drainage and depressions left from mining were cited as the causes for this low sediment yield. In mined areas of the Valley and Ridge Physiographic Province, sediment yields were high compared to unmined areas of the Valley and Ridge. The lowest sediment yields were in the sections of the Valley and Ridge Physiographic Province that are underlain by limestone. Internal drainage, presumably of karst systems, was cited as the cause for the low sediment yields in the limestone terrain.

Langland and others (1995) used suspendedsediment data for rivers draining the Chesapeake Bay watershed to examine the influence of land cover on TSS and SSC. They found that the largest median SSC was in the Upper Potomac River Basin, and the maximum SSC was in the Susquehanna River Basin. Correlations of annual sediment yields computed with a log-linear multipleregression model to land use indicated that basins with the highest percentage of agriculture had the highest sediment yields and basins with the highest percentage of forest cover had the lowest sediment yields.

For the York River system, a series of sediment budgets for 11 nested sub-watersheds ranging in size from 65 to $6,900 \mathrm{~km}^{2}$ were compared to examine distribution of sediment load as a func- 
tion of watershed size (Herman, 2001). The study showed that in low-relief Coastal Plain watersheds, sediment budgets are influenced more by the characteristics of the river system than by subwatershed size. Upland erosion was the major source of sediment in the Pamunkey River; bank erosion was the major source in the Mattaponi River. Upland storage was the major sink for both tributaries. This study also showed that little sediment from the upper watershed reached the estuary, and at the river mouth, the net movement of sediment is from the bay into the estuary.

In summary, sediment yield from upland regions of the bay watershed vary greatly because of the differences in land-use characteristics, geomorphology, and climatology of the region.

\section{Urban Sediment Sources}

Urban sediment sources change during the course of urbanization. Initial sediment sources are associated with land-surface disturbance activities from construction. After development sites have been stabilized, the mass of sediment delivered to the stream system is reduced. Sediment wash-off from post-development commonly is less than the pre-development condition. The sediment from impervious urban areas is associated with dry and wet atmospheric deposition, deterioration of road and built surfaces; and deterioration of vehicles and other human artifacts. Sediment also may be produced from pervious surfaces depending on how effectively the pervious surfaces are maintained. The construction process results in the installation of impervious surfaces and the compaction of pervious soils by heavy equipment. Both these processes result in increased runoff with the potential for increased streambed and channelbank erosion.

Construction-site runoff is the largest contributor of sediment in developing urban areas (U.S. Environmental Protection Agency, 1993). Estimates of uncontrolled construction-site sediment loadings range from 7.2 to 1,000 (tons acre ${ }^{-1}$ ) year ${ }^{-1}$. A summary of a range of studies in USEPA (1993) is shown in table 2.1. Sediment controls are estimated to be approximately 60 to 70 percent effective in trapping sediment from construction sites; erosion controls were 80 to 90 percent effective (Caraco, 1995). However, sediment traps are more effective at removing coarse-grained particles than fine-grained particles. Schueler and Lugbill (1990) found that particle-size distribution became finer in a comparison of inflow particle size to outflow
Table 2.1. Construction-site sediment loadings (from USEPA, 1993)

\begin{tabular}{|c|c|}
\hline $\begin{array}{c}\text { Sediment loading } \\
\text { (tons per acre per year) }\end{array}$ & Reference \\
\hline 35.6 to 1,000 & $\begin{array}{l}\text { York County Soil and Water } \\
\text { Conservation District, } 1990\end{array}$ \\
\hline 30 & Franklin County, FL, date unavailable \\
\hline 30 to 200 & Wisconsin Legislative Council, 1991 \\
\hline 35 to 45 & MWCOG, 1987 \\
\hline 50 to 100 & $\begin{array}{l}\text { Washington Department of } \\
\text { Ecology, } 1989\end{array}$ \\
\hline
\end{tabular}

particle size. This would indicate that although much of the sediment from a construction site can be trapped on-site through best-management practices, the sediment that is released will be finer grained.

Stabilization after construction and the eventual coverage of pervious surfaces with impervious material result in a decrease in sediment delivered from the watershed to the stream system. The installation of stormwater best-management practices results in trapping of sediment particles before delivery to the stream system.

A number of studies have looked at the relation between urban land uses and sediment. Dreher and Price (1995) reported the relation between land use and sediment delivery in pounds per inch of rain in Illinois. Their results are presented in table 2.2 with an extrapolation to $40 \mathrm{in}$. of rain, which is the long-term annual mean for central Maryland. They calculated an enrichment ratio by comparing the extrapolated sediment load for each land use to the sediment load for the woodland/wetland land-use category. As can be seen from table 2.2, land-use categories with high levels of impervious area (industrial, commercial, highways, and high-density residential) had the highest sediment loadings and consequently the highest enrichment ratios. However, their study did not determine whether the source of the sediments was from watershed wash-off from impervious surfaces, watershed erosion of pervious surfaces, or stream channel erosion.

Watershed management plans have been prepared for a number of watersheds in Baltimore County, Md. The results from the Storm Water Management Module (SWMM) pollutant load model for two of the studies (Loch Raven Watershed and Patapsco River Watershed) are presented in table 2.3. The sediment pollutant loads are higher for land uses with higher impervious area coverage. 
Table 2.2. Post-development urban watershed sediment sources (Dreher and Price, 1995)

\begin{tabular}{lcccc}
\hline \multirow{2}{*}{ Land-use category } & \multicolumn{2}{c}{ Sediment delivery } \\
\cline { 2 - 5 } & $\begin{array}{c}\text { Pounds per inch } \\
\text { of rain }\end{array}$ & $\begin{array}{c}\text { Pounds per } \\
40 \text { inches of rain }\end{array}$ & $\begin{array}{c}\text { Enrichment } \\
\text { ratio }\end{array}$ & $\begin{array}{c}\text { Milligrams } \\
\text { per liter }\end{array}$ \\
\hline Industrial & 16.18 & 647.3 & 28.53 & 120 \\
Commercial/institutional & 14.52 & 580.6 & 25.59 & 80 \\
Low-density residential & 4.53 & 181.1 & 7.98 & 100 \\
High-density residential & 8.17 & 326.8 & 14.40 & 60 \\
Vacant & 1.36 & 54.4 & 2.40 & 50 \\
Open land/urban park & 1.14 & 45.4 & 19.00 & 80 \\
Highway/arterial road & 10.90 & 436.0 & 6.00 & 150 \\
Agriculture & 3.40 & 136.1 & 1.00 & 50 \\
Woodland/wetland & .57 & 22.69 & 6.49 & 80 \\
Railroad & 3.68 & 147.3 & & \\
\hline
\end{tabular}

Table 2.3. Baltimore County Storm Water Management Module (SWMM) pollutant load results

\begin{tabular}{lcccc}
\hline \multirow{2}{*}{\multicolumn{1}{c}{ Land-use category }} & \multicolumn{2}{c}{ Sediment loads } \\
\cline { 2 - 5 } & $\begin{array}{c}\text { Loch Raven } \\
\text { Study }\end{array}$ & $\begin{array}{c}\text { Enrichment } \\
\text { ratio }\end{array}$ & $\begin{array}{c}\text { Patapsco River } \\
\text { Study }\end{array}$ & $\begin{array}{c}\text { Enrichment } \\
\text { ratio }\end{array}$ \\
\hline Commercial/industrial & 446.3 & 9.25 & 718.8 & 10.58 \\
Low-density residential & 158.1 & 3.28 & 155.1 & 2.28 \\
Medium-density residential & 213.3 & 4.43 & 285.9 & 4.20 \\
High-density residential & 279.3 & 5.82 & 410.9 & 6.04 \\
Open land/urban park & 140.3 & 2.91 & 135.6 & 1.99 \\
Crop land & 366.4 & 7.60 & 361.6 & 5.32 \\
Pasture & 243.8 & 5.06 & 306.9 & 4.51 \\
Forest & 48.2 & 1.00 & 68.0 & 1.00 \\
\hline
\end{tabular}

Using the SWMM, the Baltimore County Little Gunpowder Falls Water Quality Management Plan provided an estimate of the amount of sediment attributable to washoff from the watershed and the amount attributable to stream channel erosion. For the watershed as a whole approximately two-thirds of the sediment load was the result of channel erosion and not watershed sediment contribution. This is consistent with the findings of Trimble (1997), where stream-channel measurements from 1983 to 1993 in San Diego Creek indicated that two-thirds of the sediment yield was the result of channel erosion.

During urbanization, streams undergo three stages-an initial aggradation phase where sediment from construction activities results in sediment deposition in the stream channel; an early erosion phase where fine sediments gradually are removed, exposing gravel and cobble and the channel cross section increases; and a late erosion phase where the channel down cuts and widens along its entire reach. Miller and others (2000) measured channel change for historical cross sections in Watts Branch, in the Piedmont Province of Montgomery County, Md. Their studies showed that between 1972 and 1993, the streambed aggraded because of the deposition of sediment from construction. This was accompanied by channel widening and an increase in cross-sectional area between 1993 and 1999. Hammer (1972) examined the changes caused by urbanization in the Piedmont of southeastern Pennsylvania and found that an increase in discharge is accompanied by stream channel widening that takes place over a 10 to 20-year period. Robinson (1976) studied streams in the Piedmont of Maryland and concluded that urbanization increased channel area approximately two times and width/depth ratios 1.7 times those of rural channels. He postulates that it takes at least 15 years for a stream to reach a new equilibrium form following development.

Effective land-use planning and sediment control can help reduce the impacts of the aggradation phase on the streams. Stormwater management with peak and volume control, preferably near the source, will help reduce the impacts of the 
erosion phase. Beyond these measures, effective buffer creation and management and stream restoration also are available tools for stream protection and improvement.

\section{Channel Corridor Sources}

The channel corridor refers to the channel bed, banks, and floodplain areas of a stream. In ecological terminology, the channel corridor is called the riparian zone. Streambank erosion occurs in channel corridors through the direct removal of banks and beds by flowing water, typically during periods of high flow. The meandering (side to side) movement of a stream is a natural process whereby streams adjust their channel shape in response to flows over long periods of time. Geomorphologists commonly use the term "equilibrium" to characterize the size and shape of a stable channel and the amount of sediment "naturally" generated within a basin. Lane (1955) suggested that the energy of a stream is a function of the speed and volume of water, and this energy must be in balance with the size and volume of sediment transported by the stream. Anthropogenic land disturbance (clearing of land, urbanization, channelization) severely alters this natural equilibrium. In practical terms, this means that if either the volume (increased runoff) or velocity (steeper slopes) of water increases, the increase in stream energy will increase the sediment-carrying capacity of the stream. The usual source for this additional sediment from increased stream energy comes from the stream channel (bed and banks), which undergo erosion.

After the equilibrium of a stream is disrupted, a series of events take place that are described by the Channel Evolution Model (Simon, 1989). In this model, disruption causes the channel to cut deeper and increases water storage, which in turn increases stream velocity. This increase in velocity results in streambank erosion, a widened stream channel, and the development of new floodplain at a lower elevation in the stream channel. After the process of downcutting has begun, it will continue to downcut upstream until a grade control (bedrock, culvert) is reached or until the stream once again reaches equilibrium.

Despite the development of explanations for the form and adjustment of stream channels in the Chesapeake Bay watershed, relatively little sitespecific information on stream adjustment and its relation to bank erosion and sediment flux is available. Even less data are available on the quantification of sediment loss and particle-size transport as a result of bank erosion. However, available studies indicate a wide range in erosion rates, from a few inches per year in a "naturally" stable stream to as much as $5 \mathrm{ft}$ per year in areas of the Piedmont. For example, in urbanized watersheds in the Piedmont areas of Pennsylvania, streambank erosion can exceed sediment accumulation and bank rebuilding, resulting in the enlargement of the channel (Hammer, 1972). However, Leopold (1973) observed a decrease in channel cross-sectional area in the Piedmont of Maryland during a period of intense development in the watershed. This is, perhaps, an indication of sediment accretion. Pizzuto and others (2000) more recently observed that urbanized channels were approximately 26 percent larger in cross-section area than rural channels in the Piedmont of Pennsylvania.

Although the contribution of sediment from streambank erosion may be a significant sediment source in many streams in the watershed, the percentage of "unstable" streambanks in the bay watershed is not known. Several promising lines of research may address this lack of information. For example, measurement of cosmogenic isotopes can provide estimates of bank sediment in terms of its percentage contribution to load of total sediment. Modeling studies also have potential to determine bank erosion and sediment transport derived from sediment particle-size data from the bank and floodplain. In one such study, the USCOE analyzed floodplain sediments from previously sampled and flow-gaged USGS sites in the Susquehanna River Basin and found that most of the bank material in the lower Piedmont areas is composed of fine sands and silts that can be easily eroded and transported as suspended material (Megan Jones, U.S. Army Corps of Engineers, oral commun., 2003).

The diversity of topographic and geologic conditions within the watershed and the complexity of hydraulic conditions in natural channels commonly limit the use and applicability of information from site-specific study areas for broader watershed-wide applications. As a result, modeling the effect of channel adjustments on sediment supply to channels has limited predictive value. In summary, quantitative estimates of how stream restoration and other best-management practices influence streambank erosion and resulting sediment delivery to the tidal estuaries and the main stem bay remain imprecise. 


\section{CHAPTER 3. WATERSHED SEDIMENT TRANSPORT}

\author{
by Sean Smith, ${ }^{1}$ Michael Langland, ${ }^{2}$ \\ and Robert Edwards ${ }^{3}$
}

This chapter provides an overview of the physical processes associated with stream-channel adjustment in the Chesapeake Bay watershed, and the relation between the processes of adjustment and sediment flux. A brief explanation of differences in channel appearance and behavior within the watershed are discussed to provide perspective on the conditions that are capable of generating changes in the rates and magnitudes of sediment movement to the Chesapeake Bay.

\section{Channel Hydraulics and Sediment Transport}

The Chesapeake Bay watershed contains a variety of landscapes including steeply sloped mountains of the Appalachian, Valley and Ridge, and Blue Ridge Physiographic Provinces, dissected landscapes of the Piedmont and western Coastal Plain Physiographic Provinces, and flat areas on the Delmarva Peninsula (Langland and others, 1995). Stream channels have different characteristics in each of these regions that reflect the influence of the long-term geologic processes that created the dominant topographic and sedimentary environments. The appearance, stability, and modes of channel adjustment differ in each of the physiographic settings. Consequently, responses to changes in land use vary across the Chesapeake Bay watershed, resulting in different changes in the flux of sediment through channel networks. The inconsistency in channel adjustment and related sediment-transport dynamics requires that the approaches used for stream-stabilization projects related to sediment management be partly customized to address specific hydraulic and geomorphological conditions.

\section{Channel Morphology and Hydraulics}

Stream and river channels are landform elements that have their dimensions and patterns governed by water flow and sediment supply. A stream reach can be described using three differ-

\footnotetext{
${ }^{1}$ Maryland Department of Natural Resources.

${ }^{2}$ U.S. Geological Survey.

${ }^{3}$ Susquehanna River Basin Commission.
}

ent perspectives-cross section, longitudinal view, and planform views. Different dimensional measurements are associated with each perspective.

The channel "cross section" dimension governs the width and depth of the flow area, which affects flow velocities. Collectively, the width, depth, and flow velocity comprise the hydraulic geometry of the channel, which has a direct relation to sediment transport. Several attempts have been made in the bay watershed and similar settings in the mid-Atlantic to characterize the relations between stream channel cross-sectional dimensions and flow characteristics using the hydraulic geometry framework initially proposed by Leopold and Maddock (1953). These have included the investigation of Kolberg and Howard (1995) on the hydraulic geometry of Piedmont channels, the analysis of the factors affecting downstream changes in cross-sectional morphology in the Valley and Ridge Physiographic Province of central Pennsylvania by Pizzuto (1992), a survey of Maryland Piedmont and Coastal Plain channels by Prestegaard and others (2000), and the survey of bankfull discharge and channel characteristics in the Piedmont in Maryland by McCandless and Everett (2002). Although the flowconveyance characteristics of streams are dependent partly on the sediment concentrations and supply, only the approach used by Pizzuto directly considered sediment discharge as an independent variable. This limits the utility of the other investigations because trends associated with downstream changes in channel conditions cannot be fully explained without sediment information.

The "longitudinal" profile also governs flow cross-sectional area and velocity through its relation to the energy gradient, which is approximated by the slope of the water surface in the downstream direction. Within a channel reach, the slope governs the force and power of the water flow, which determines the capability to transport sediment. At the scale of an entire drainage network, profiles usually are sloped more steeply in headwater areas than at basin outlets. Geomorphic analysis of longitudinal profile characteristics of streams in the Valley and Ridge, Blue Ridge, Piedmont, and Coastal Plain Physiographic Provinces in the Chesapeake Bay watershed has been attempted (Hack, 1957). However, systematic trends between the downstream progression of the profile and channel bottom sediment characteristics are difficult to resolve in many river networks because of localized changes in geology. 
Natural stream and river channels that are formed by water flow and sediment deposition are composed of an active channel (bankfull flow) and an adjacent floodplain (flood flow) (fig. 3.1). The primary flow regimes in streams and rivers can be partitioned into:

- base flows that originate as slow releases of ground water or surface water from ponds in the absence of precipitation and have little capacity to transport sediment;

- bankfull flows that fill channels up to the tops of their banks, (these flows have been found to be important determinants of the channel dimensions because they can be the most "effective" conveyors of sediment over extended time periods (Wolman and Miller, 1960; Leopold and others, 1964; Dunne and Leopold, 1978)); and

- flood flows that over top streambanks. (These flows affect channel stability through dramatic erosion and sediment transport in brief periods of time (Baker and others, 1988; Grover, 1937; Smith, 1997; Smith and others, 1999). The flood of January 1996 provided an example of the role of floods in sediment movement into the bay, transporting approximately 17 times the amount of sediment normally delivered to the Chesapeake Bay in the same month (Zynjuk and Majedi, 1996)).

\section{Channel-Shaping Processes and Sediment Flux}

Two questions related to stream channels and sediment remain difficult to answer in the Chesapeake Bay watershed:

-When can a stream channel be considered stable?

- What discharges have the greatest influence on the channel form?

The term "equilibrium," more accurately stated as "steady-state equilibrium," commonly is used to describe the condition under which the average shape and dimensions of a stream are maintained over a period of time, such as several decades or a century (Schumm, 1977). Channel changes can occur within a stream in equilibrium in response to changes in sediment supply, but they are localized in a reach and last for relatively short periods of time. Short-term widening and contraction of channels in response to erosion and deposition of sediment during floods are examples of this variability, as observed by Costa (1974) in the Piedmont following Hurricane Agnes in 1972. Wolman and Gerson (1978) also described changes in the channel width following flooding in Baisman Run and the Patuxent River in Maryland.

The perpetuation of an equilibrium channel condition requires consistent watershed conditions (Carling, 1988). Watershed changes that alter the frequency and magnitude of water and sediment discharges make it difficult to maintain consistent channel conditions over time (Werrity, 1997). Virtually all the watersheds draining to the Chesapeake

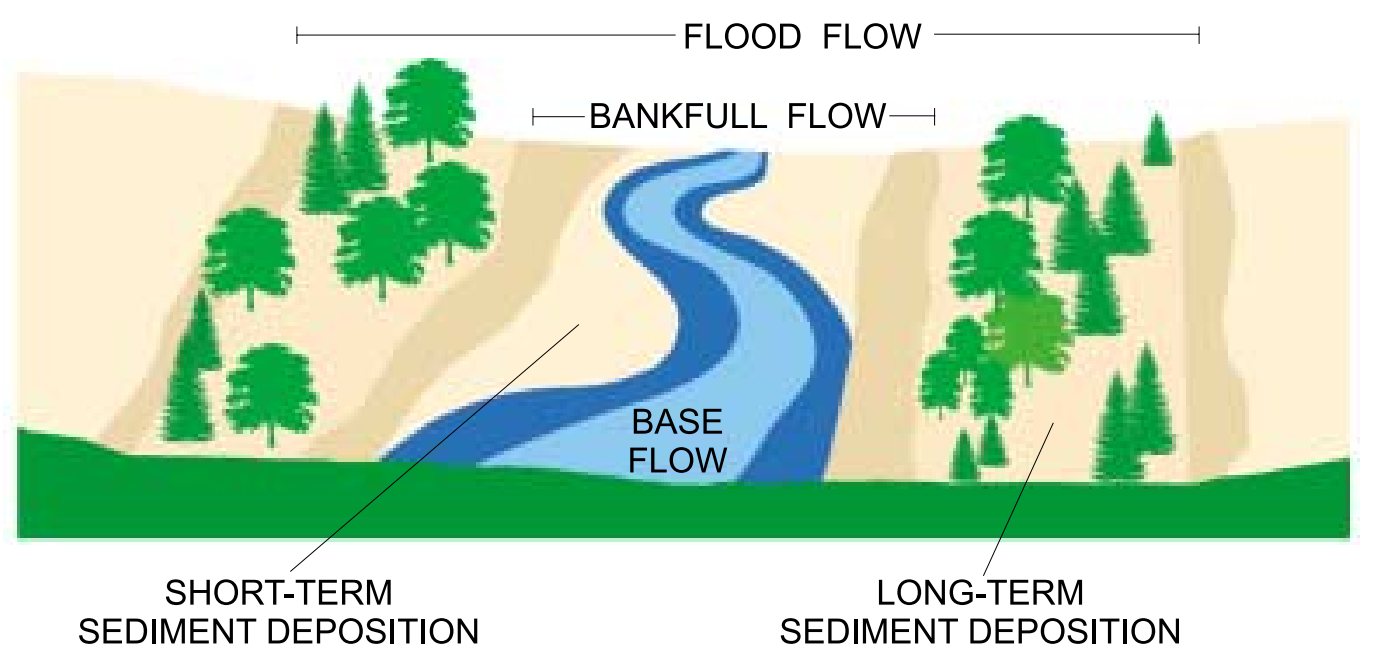

Figure 3.1. Flow regimes affecting stream-channel and floodplain corridors (Modified from Smith and others, 2000). 
Bay have experienced numerous changes in land use over the past century. As a result, few, if any, stream networks have experienced steady-state equilibrium conditions since European colonization.

The shape and dimension of a stream channel is influenced collectively by the frequency, magnitude, and velocity of the flows passing through the channel, the type and amount of sediment supplied to the channel, and the structural characteristics of the stream channel bed and banks. In the absence of structural controls, the capacity of the reach to convey supplied sediment is an important factor affecting channel shape and dimension. Channel reaches in the bay watershed that have received excessive sediment loads from agricultural fields or urban construction activities may not be capable of transporting all the supplied materials. This can result in the temporary build up of sediments and braided conditions with multiple bars and channels. Conversely, many channels that have received increases in flow without simultaneous increases in sediment supply have degraded because of a net export of sediment.

"Bankfull discharge," "dominant discharge," and "effective discharge" are terms used by engineers and geomorphologists to describe the flows that have the greatest influence on the channel dimension. Each has a direct or indirect relation to the frequency and magnitude of sediment transport. The concept of relating a single discharge to an optimized condition of sediment flux and channel stability has become a popular focus for the design of stream-channel restoration projects in the Chesapeake Bay watershed. Procedures for calculating effective sediment discharge have been published by the USCOE; however, the oversimplification of the relation between sediment discharge and channel dimensions to a single discharge limits applicability with broad-scale use in the development of channel designs (Biedenharn and others, 2000).

The patterns of channel migration across a valley also relate to sediment flux through a reach. In naturally meandering channels, bank erosion on the outside of a meander bend can be compensated by the accumulation of deposited sediment (bank rebuilding) on the inside of the bend. If the rates of erosion and accumulation are similar, the channel will change its position but maintain its cross-sectional dimension. This condition is sometimes termed "dynamic equilibrium" because it is a form of stability. However, increased flows and decreased sediment loads disturb this equilibrium. Areas on the inside of a bend that normally aggrade with sediment can experience net erosion, thereby resulting in an apparent straightening of the channel centerline and an increase in the channel width and average depth. The effect of channel straightening caused by increases in flows and decreased sediment supplies can be observed in many urbanized areas such as the Washington, D.C., and Baltimore metropolitan areas. Channels in urbanized Piedmont settings in Pennsylvania have been characterized by lower sinuosity than those in rural areas (Pizzuto and others, 2000).

The process through which streams become straightened often is related to channel widening. In unprotected urbanized watersheds, increased streambank erosion can exceed sediment accumulation and bank rebuilding, resulting in the enlargement of the channel. These trends were documented by a survey of channels in urbanizing watersheds in Piedmont areas of Pennsylvania (Hammer, 1972). However, a decrease in channel cross-sectional area was observed by Leopold (1973) in the Piedmont of Maryland during a period of intense development in the watershed. Wolman and Shick (1967) previously had developed a model of stream response to land-use changes that characterized changing sediment flux and associated channel adjustment in Piedmont channels near Baltimore. The changes identified included stable conditions under fully forested watershed conditions, aggradation in response to forest clearing for agriculture, degradation of channels as agricultural land goes fallow, pronounced aggradation during urban construction, and removal of accumulated sediment following the termination of construction as channels adjust to the reduced sediment supply and urban storm flows.

Progressive channel incision is another mode of adjustment that commonly occurs in streambeds composed of easily erodible materials. Channels cut downward when the export of sediment from a reach exceeds the sediments imported into a reach (fig. 3.2). This condition creates a location of high sediment supply from a localized stream reach that persists until the gradient of the channel is reduced to a level that no longer promotes a net erosion of materials. Incision processes commonly involve the upstream progression of a headcut. Wolman (1987) has described such processes and their relations to sediment flux in a 


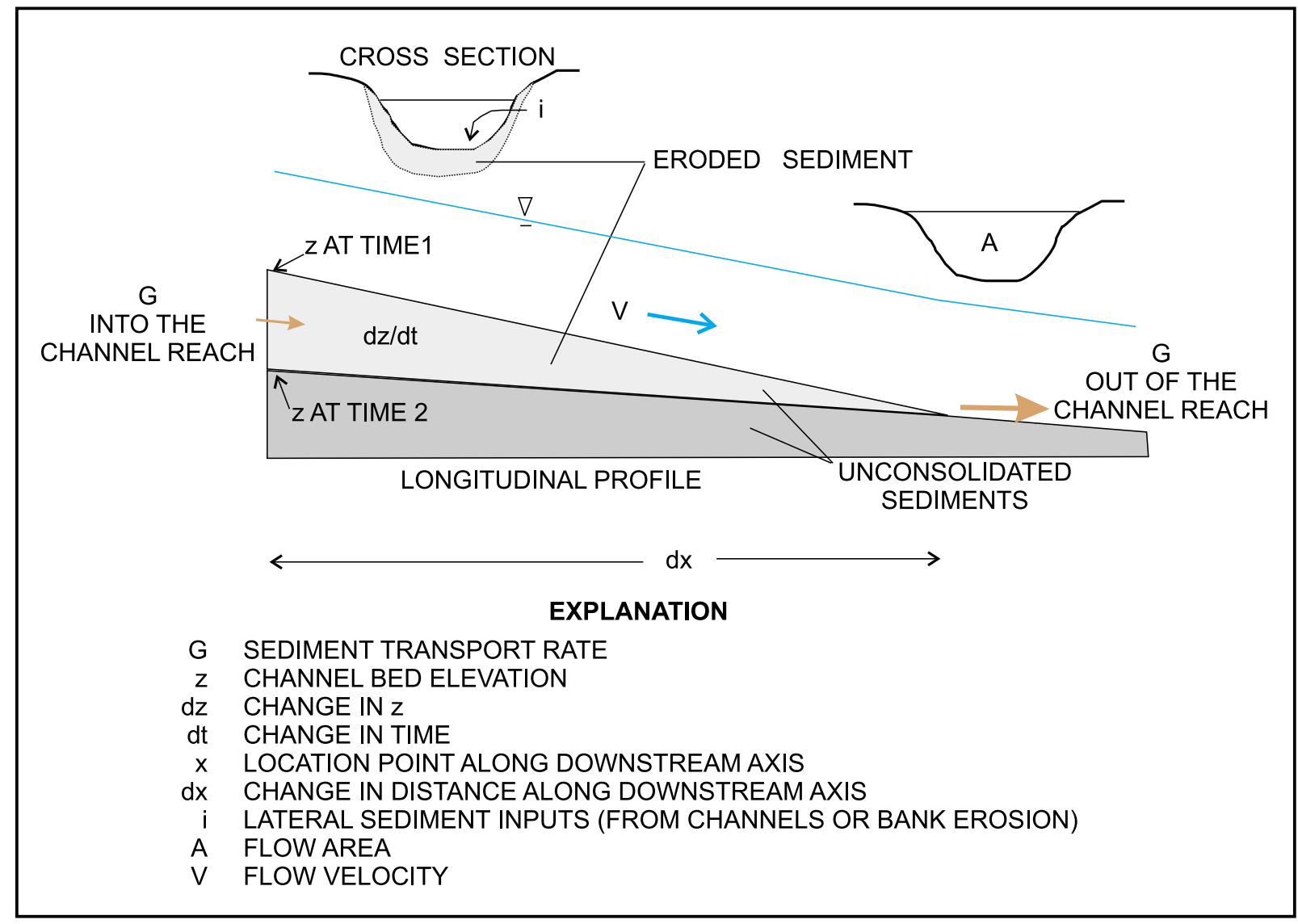

Figure 3.2. Relations between profile location, sediment flux, and channel incision, defined as [ $d z / d t=\left(1 / \gamma_{s}\right)$ $(\mathrm{dG} / \mathrm{dx})+\mathrm{i}$,] where $\mathrm{dz} / \mathrm{dt}=$ change in channel bed elevation with time, $\mathrm{dG} / \mathrm{dx}=$ change in bedload transport with distance downstream, $\gamma_{S}=$ specific gravity of sediment (Modified by S. Smith from Richards and Lane, 1997).

second-order stream channel in the Piedmont Physiographic Province of Maryland. Observations included the movement of a headcut approximately $18 \mathrm{~m}$ upstream over 3 years, episodic movements of gravels, and the transport of the majority of suspended sediments in episodic highflow events during the monitoring period.

First- and second-order channels in the Western Shore of the Coastal Plain are particularly prone to downcutting because they are steep enough to generate erosive flows and are composed of highly erodible materials, such as unconsolidated sand. These headwater channels receive limited sediment contributions to compensate for channel erosion, which promotes vertical downcutting. This is particularly characteristic of urbanized watersheds. Unfortunately, the contribution of sediment from erosion in the headwaters of the Coastal Plain and Piedmont to sediment loading in the Chesapeake Bay has not be quantified for any time scale. A complication in developing such an estimate is that stream maps accurately delineating small first-order channels prone to incision are not readily available for the Chesapeake Bay watershed.

Specific geomorphic processes associated with incision can vary with the landscape setting and climatic conditions. Steeply sloped first- and second-order channels in the Appalachian Plateau, Valley and Ridge, and Blue Ridge Physiographic Provinces can generate high-energy flows; however, bedrock prohibits down-cutting by erosion over short time scales. Hillslope processes that move large amounts of sediment over short time periods, such as debris flows and landslides, can alter channels on steep slopes during extreme precipitation events. In the Rapidan River Basin in Virginia, floods and debris flows in 1996 provided 
evidence of such events; however, these events are rare in most of the Chesapeake Bay watershed (Gori and Burton, 1996).

\section{Channel Sediments}

Sediment sizes generally are divided into clays (less than $0.004 \mathrm{~mm}$ ), silts (0.004-0.062 mm), sands $(0.062-2 \mathrm{~mm})$, gravels $(2-64 \mathrm{~mm})$, cobbles (64-256 mm), and boulders (greater than $256 \mathrm{~mm}$ ). To some extent, lithology and transport mechanisms determine the shapes of the particles, which can range from spherical to platy. The variability of lithologic conditions throughout the Chesapeake Bay watershed create a diversity in the size distributions, densities, and shapes of sediment being transported downstream towards the Coastal Plain rivers and Chesapeake Bay (Smith and others, 2000). Changes in the grain-size distribution on and within the channel bed also can occur. These changes usually are characterized by a reduction in the median grain size with distance downstream in large drainage networks. Changes in bed grain sizes also can occur over relatively short distances, as observed by Prestegaard and others (2000) in the reach of Northwest Branch traversing the Fall Zone near Washington, D.C. (fig. 3.3).
Individual sediment particles move either by remaining in suspension in the water column or by rolling, skipping, or hopping along the bottom of the channel as "bedload" (Vanoni, 1975; Yorke and Herb, 1978; Meade and others, 1990). The part of the total sediment load moving in the water column can be further partitioned into the "suspended load," which is characterized by a concentration that decreases with elevation above the channel bed, and "wash load," which has a homogeneous distribution through the water column (Leopold and others, 1964; Vanoni, 1975).

\section{Suspended-Load and Wash-Load Transport}

Sediment moving in suspension is entrained in response to flow velocities and turbulence. Material in suspension generally consists of particles of fine sand, silt, and clay. Because suspended sediment concentrations depend on grain size and flow velocity, the rates of removal of fine sediments from suspension from the water column can take extended periods of time and require very low flow velocities. Hence, the management of fine sediment after it is brought into suspension can be difficult or impossible with standard best-management practices, including sediment ponds.

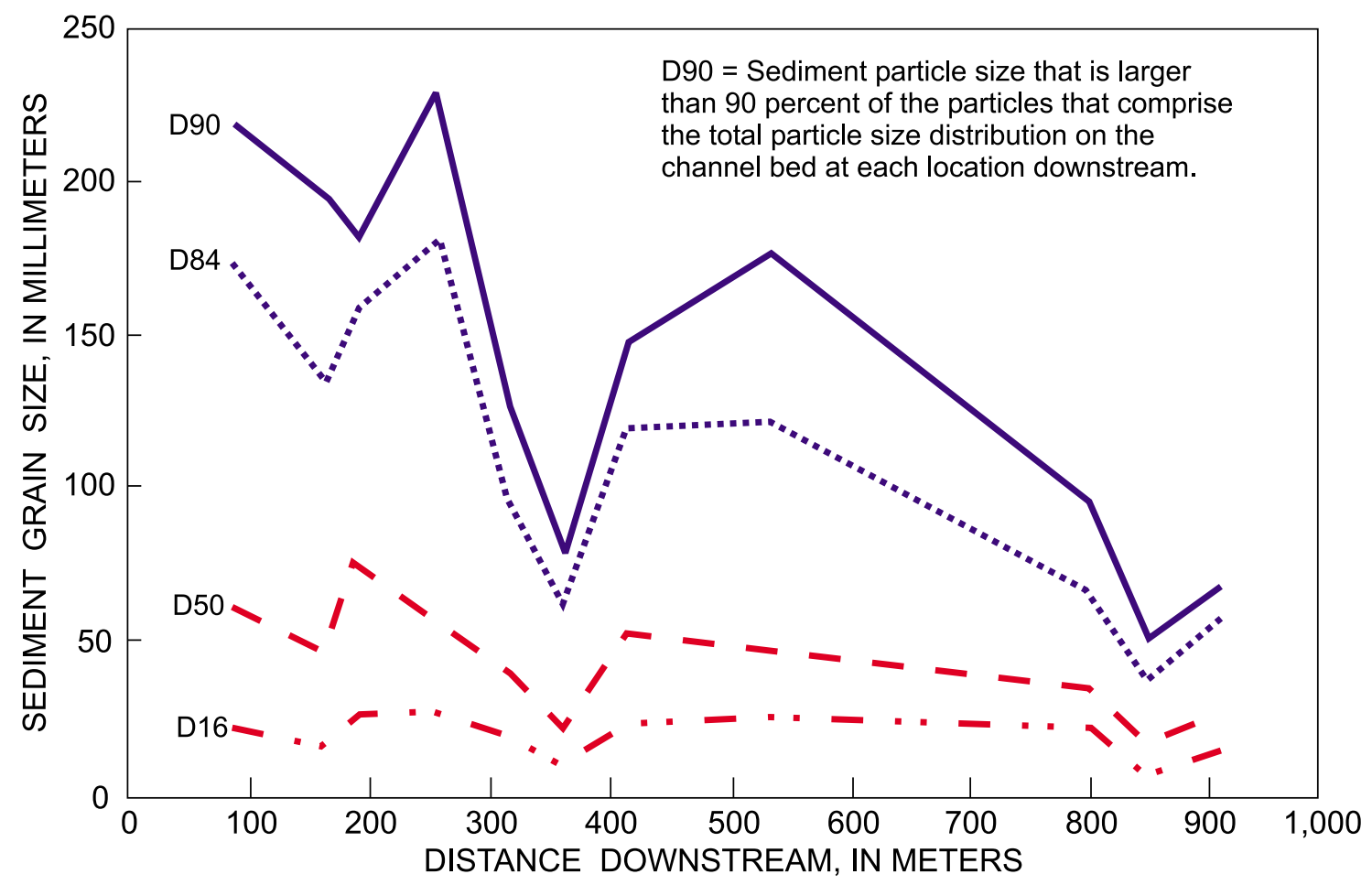

Figure 3.3. Changes in channel-bottom sediment sizes in the Fall Zone near Washington, D.C. (Modified from Prestegaard and others, 2000). 
Suspended-sediment transport commonly is evaluated using sediment concentration and velocity profiles that describe conditions through the water column (Leopold and others, 1964; Garcia, 1999). The sediment profiles are represented as a function of the ratio of the sediment concentration at different levels through the water column to the sediment concentration near the bed. Development of computer simulations of suspended-sediment transport is complicated because of complex flow phenomenon associated with turbulence and distortions. The same problems make the collection of suspended-sediment data difficult, particularly if the hydraulic condition at a sampling location is complicated by changing roughness distributions or asymmetry in the cross-sectional geometry (Gray, 2002). Suspended-sediment information collected in the Chesapeake Bay watershed commonly is collected as TSS, which includes both inorganic and organic materials. This method may misrepresent the total sediment transport in some watersheds (Gray and others, 2000).

\section{Bedload Transport}

Similar to suspended load, sediment transported as bedload is driven by the force of the water flow. The amount of force required to initiate motion of a particle depends on its size, density, shape, and position relative to other particles. Although estimating bed load transport accurately is difficult, relations between bedload transport and water flow have been examined by numerous authors (Vanoni, 1975; Wohl, 2000). Approaches used to predict bedload transport usually are based on a well-known set of governing equations for the conservation of flow, mass, and momentum and represented using constitutive relations developed through experimentation that describe how sediments with different characteristics respond to water flows (Vanoni, 1975; Wohl, 2000; Middleton and Wilcock, 1994; Meade and others, 1990).

Little bedload information is available in the Chesapeake Bay watershed and no programmatic efforts are planned to gather data. However, bedload transport can be important in localized areas because of its relation to channel stability and adjustments. Bedload generally is less than 20 percent of the total sediment transferred from continental uplands to the coastal margins (Yorke and Herb, 1978, Vanoni, 1975). However, bedloadtransport rates and magnitudes can significantly affect channel hydraulic geometry and stability in gravel-bed rivers. This also can affect the total sed- iment yield from a reach, including fine sediments moving in suspension. The influence of bedload transport on channel stability and TSS yield can be particularly important in several unique areas of the Chesapeake Bay watershed where large quantities of gravel and cobble materials are supplied from bedrock or upstream areas. The northern areas of the Appalachian Plateau where past glacial activity has deposited large amounts of gravel overburden materials are one such location. The Fall Line between the Piedmont and Coastal Plain Physiographic Provinces is another geomorphically unique location where the bedload movements of coarse gravels supplied in pulses can promote large localized changes in channel flow conveyance capacities over short time periods (Smith, 1997).

The frequency and magnitude of the transport of coarse sand and gravels has potential implications for stream and river channel stability, the development of stable channel engineering protocols, and assessments of aquatic habitat (Biedenharn and others, 2000). Many formulas for estimating gravel transport as bedload have been developed from experimentation using singlesized sediment. These experimental approaches have, for the most part, evaluated mixed-sized sediments as simple percentages of sand. However, changes in the sorting of mixed-sized sediments during transport affect transport rates for gravels. This may have relevance to the effect of construction sediments on total sediment transport in urbanizing watersheds (Wilcock, 1998; Wohl, 2000).

Watershed changes that directly alter the supply of sediments naturally transported as bedload can include channel engineering and damconstruction activities. Changes indirectly influencing bedload transport conditions can include increases in the frequency and magnitude of discharges associated with forest clearing and urbanization, and truncated peak flows from large reservoirs with large storage capacities for water and sediment.

Field data necessary to estimate bedload transport are difficult to collect because bedload sampling requires sampling bottom materials across the width of a channel, commonly during high-flow conditions (Edwards and Glysson, 1988). Estimates can be developed using experimentally derived bedload transport functions; however, the error can very high. A variety of 
channel bottom and bar sediment sampling techniques have been developed to estimate bottom sediment grain size, which serves as an independent variable in most bedload transport functions (Wolman, 1954, Wohl, 2000). Some of these sampling methods have been popularized for use in stream-channel assessment exercises conducted by many agencies and their consultants in stream management and channel-rehabilitation projects throughout the country, including the Chesapeake Bay watershed (FISRWG, 1998).

Although bedload is a relatively minor percentage of the total sediment load delivered to the Chesapeake Bay, bedload-transport characteristics of the gravel-bed rivers flowing through the bay watershed influence the total sediment load, including fine sediment transported in suspension. Measured bedload-sediment data would be helpful to evaluate total sediment loading, to perform stability assessments in gravel-bed streams, and to develop stream-channel stabilization designs. To date, very few attempts have been made in the bay watershed to collect bedload information in conjunction with stream channel assessment or rehabilitation projects conducted in the past decade (Mallonee and others, 2002; McCoy and others, 1997). Therefore, almost no information exists on the relation between bedload and total sediment yield to the Chesapeake Bay.

\section{$\underline{\text { Reach-Specific Sediment-Transport }}$ Characteristics}

Sediment materials are transported from the first-order channels in the headwaters of watersheds to the higher-order channels and the basin outlets. However, the rate of transport for the grain sizes supplied by a watershed is not constant over time or consistent through a drainage network. The amount of sediment that moves through a reach depends on the amount of sediment input, the magnitude, frequency, and duration of flows, and the hydraulic geometry of the channel. For example, incising channel reaches associated with low order (headwater) streams commonly release more sediment than they receive. This sediment can become stored in bars and adjacent floodplains in downstream reaches that receive more sediment than they can transport. In some localized areas, such as the "Fall Line" border between the Piedmont and Coastal Plain Physiographic Provinces, sediment from upstream is conveyed through a reach in pulses that coincide with high flows (Smith, 1997).

Sediment stored in stream-channel bar formations and on the floodplain can provide a history of changing land-use activities. Distinct changes to the morphology of the active channel and floodplain have been observed in response to alterations in watershed hydrologic conditions and sediment supply (Jacobsen and Coleman, 1986). Three defining periods of sedimentation were identified by Jacobsen and Coleman (1986) in relation to observed floodplain strata (fig. 3.4).

Pre-settlement period: The Piedmont floodplains were formed over long periods of time by the settling of fine sediment in the wooded areas adjacent to active stream channels.

Agricultural period: Widespread establishment of farming caused dramatic increases in sediment supply and the deposition of significant layers of sediment in the floodplain over a relatively short time period.

Very recent period: Reduced agricultural activities and improved sediment control have decreased sediment supply from over-land sources. Stored sediment in floodplain deposits are reworked, resulting in the downstream transport of fine sediments and the reworking of coarse sediments into bar deposits. 


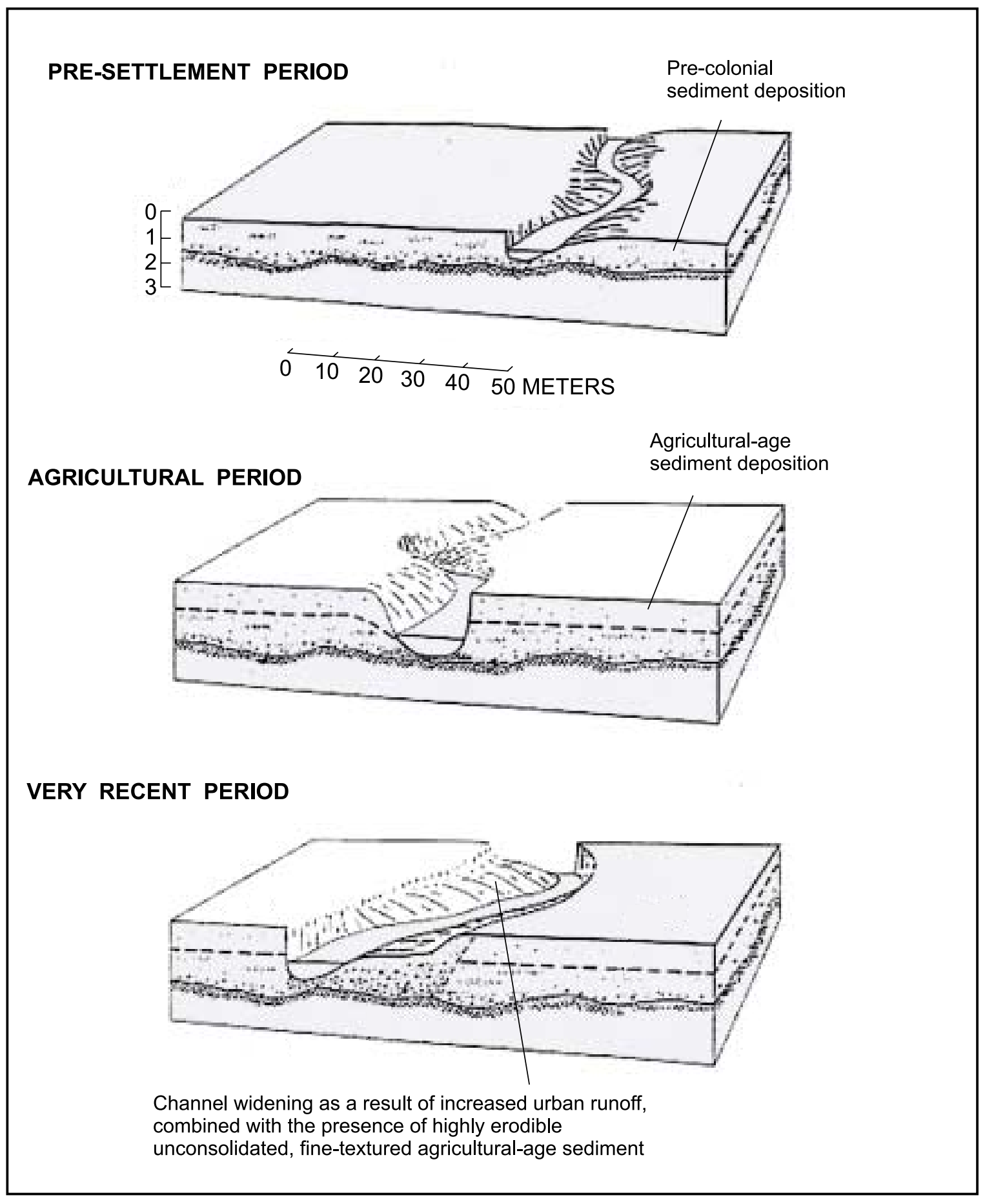

Figure 3.4. Floodplain stratigraphy observed by Jacobsen and Coleman, partitioned into three defining periods of sedimentation (Modified from Jacobsen and Coleman, 1986). 


\section{CHAPTER 4. WATERSHED SEDIMENT DEPOSITION AND STORAGE}

\author{
by Julie Herman, ${ }^{1}$ Clifford Hupp, ${ }^{2}$ \\ and Michael Langland ${ }^{2}$
}

Sediments eroded from the land surface are stored in the Chesapeake Bay watershed in three primary places: upland surfaces, in reservoirs behind dams, and in floodplain riparian regions. This section discusses studies relevant to the storage of sediment that has been eroded but has not yet reached the bay or its tributaries. A discussion of legacy sediments, defined as those sediments eroded during extensive colonial land clearance and temporarily trapped in the watershed, is presented in Chapter 6 on Deposition and Sedimentation Rates.

\section{Upland Storage}

This section reviews recent papers on upland sediment storage. Upland sediment storage refers to sediment that has been mobilized in upland regions and redeposited on the upland surface before reaching a stream. This type of sediment is referred to as colluvium, and its storage may constitute a large percentage of material eroded from uplands. Although colluvial sediment can be difficult to measure, its residence time in upland storage and its delivery to stream courses may have important implications for water-quality management.

Colluvium is deposited at the base of hillslopes, at field edges, in buffers, and in swales and depressions (isolated wetlands). Evidence of the importance of sediment storage and remobilization as a source of sediment in drainage basins of various scales is increasing (Walling, 1988). Watershed studies have shown that a large percentage of the total sediment eroded is stored as colluvium. During a study on Coon Creek, Wis. $\left(360 \mathrm{~km}^{2}\right.$ drainage area), Trimble (1981) found that 38 to 63 percent of upland-source sediment was deposited as colluvium. In four large $\left(>1,000 \mathrm{~km}^{2}\right)$ drainage basins in the Piedmont of North Carolina, colluvial storage was estimated to be 71 to 81 percent of mean annual sediment production (Phillips, 1991b). In Western Run, a Piedmont watershed in Maryland, Costa (1975) found that 52 percent of sediment eroded from agricultural

\footnotetext{
${ }^{1}$ Virginia Institute of Marine Science.

${ }^{2}$ U.S. Geological Survey.
}

lands was stored as colluvium. In a series of nested sub-watersheds in the York River watershed (Piedmont and Coastal Plain Physiographic Provinces of Virginia), 57 to 74 percent of upland erosion was stored as colluvium (Herman, 2001).

Buffers tend to decrease the velocity of overland flow and trap colluvial sediment by deposition. Buffers may be grassy, forested, or zoned and usually are at field edges or in riparian zones. In areas with lower slopes, such as the Coastal Plain Physiographic Province, buffers appear to be more effective (Dillaha and Inamdar, 1996). In forested riparian areas, more than 50 percent of the sediment eroded in cultivated fields was deposited within $100 \mathrm{~m}$ of the field margins (Cooper and others, 1987). Fine particles also may enter the soil profile with infiltrating water (Dillaha and Inamdar, 1996).

A technique commonly used to estimate upland storage is called the sediment delivery ratio (SDR). The SDR is the ratio of sediment reaching a basin outlet compared to the total erosion within the basin (Walling, 1983). The portion of mobilized sediment that is not delivered to a stream channel remains on the upland as colluvium. The following discussion of SDRs includes only the transport pathway from upland erosion to stream edge. Values for SDRs range from 0 to more than 1 and commonly are found to decrease primarily with an increase in drainage area. A ratio in excess of 1 implies that delivered load exceeds gross erosion and that additional stored sediment is being mobilized (Walling, 1983; Novotny and Chesters, 1989).

The Chesapeake Bay Program watershedmodeling effort assumes that basins between 13 and $259 \mathrm{~km}^{2}$ have ratios that vary between 0.1 and 0.22 , respectively, and 0.18 is used as a constant SDR from field to edge of stream for the sub-watersheds (L. Linker, U.S. Environmental Protection Agency, oral commun., 1996). Values for Virginia Agricultural Pollution Potential Database (VirGIS) SDRs in the York River watershed range from 0.01 to 0.96 ; the mean is about 0.31 for crop and pasture land and 0.06 for all land uses (crop, pasture, forest). For comparison, the SDR for the Yadkin/Pee Dee River system in North Carolina $\left(47,900 \mathrm{~km}^{2}\right)$ is 0.039 (Phillips, 1991a).

The SDR concept has limitations (Walling, 1983; 1994). Considerable uncertainty surrounds the methods for calculating SDRs, and there is no generally applicable predictive equation. Walling 
(1983) cites examples of proposed delivery ratio equations, all of which relate 'larger-scale' catchment properties (such as basin area and basin relief) to sediment delivery. No equations were available using parameters that define the landsurface pathway over which sediment-laden water flows, such as surface roughness and soil permeability.

Another problem is that sediment delivery also may be discontinuous over temporal and spatial scales. Sediment eroded in the headwaters may be stored, while sediment remobilized from downstream is transported out of the basin (sediment decoupling) (Phillips, 1995), making SDR estimates inaccurate. In smaller basins, there is less opportunity for sediment storage so the SDR may not be as susceptible to the lag time. Spatial diversity of topography, land use, and soil conditions illustrates the problems of spatial lumping and the attempts to represent sediment delivery of a watershed with a single number. Therefore, SDRs should be used with caution (Novotny and Chesters, 1989).

A strategy to partially rectify these concerns is to apply the delivery ratio concept on a distributed basis using a grid of square cells (Walling, 1983; VirGIS reports). In one approach, VirGIS used a first-order exponential function that was assumed to approximate the amount of sediment moved from a cell to a receiving stream. The equation includes the influence of vegetative cover and the steepness and length of the flowpath (VirGIS reports). Because 'correct' estimates virtually are impossible, VirGIS calculated an SDR that generally reflects expected trends (Shanholtz, 1988). Another method is to calculate gross erosion for each cell and then sequentially route sediment downslope through adjacent cells towards a channel, with a proportion of material being redeposited along the transport pathway until a final edgeof-stream value is obtained. Distributed delivery ratios were developed for total suspended solids from trapping efficiencies of vegetated filter strips, but their results overestimated total sediment load (Levine and others, 1993). Although the distributed approach possesses certain merits, in practice it may offer little advantage over a lumped method because of uncertainties in assigning delivery terms to individual cells (Walling, 1983).

Several other methods hold promise for quantifying colluvial storage. For example, Cesium-137, a short-lived radioisotope has been used to examine relatively recent sediment redistribution on agricultural fields (Fredericks and Perrens, 1988). Long-term (decadal to historic time scales) redistribution of sediment also can be examined by measuring changes in soil morphology, especially the truncation and accretion of soil profiles. For example, Phillips and others (1999) examined the fluvial, aeolian, and tilling processes that redistribute soil in a small watershed in North Carolina. They discovered that sediment was deposited immediately downslope from convexities, forming thin fan deposits at toe slopes, in depressions, and at the borders of fields.

\section{Floodplain and Banks}

The Coastal Plain of the southeastern and mid-Atlantic United States is characterized by a broad, frequently inundated low-gradient flood plain. These riparian systems have received considerable ecological study but distinctly less hydrogeomorphic study. Data on quantitative process linkages among hydrology, geomorphology, and ecology remain largely undocumented. Although sometimes heavily affected by land use, these flood plains and their bottomland hardwood systems remain a critical landscape element for the maintenance of water quality by trapping and storing large amounts of sediment and associated contaminants. Nearly 90 percent of all sediment is trapped for varying periods of time along streams before reaching saltwater (Meade and others, 1990). Thus, these flood plains are the last place for sediment storage before entering critical estuarine nursery areas for fish and wildlife.

Jacobsen and Coleman (1986) outlined a flood plain-development model that described morphological changes in Piedmont alluvial channels flowing through stored (legacy) sediment deposits. They concluded that current changes included the erosion of the fine floodplain sediments and storage of coarser materials in lag deposits that developed into channel bar formations. Localized storage reaches also have been identified by Smith and Prestegaard (Sean Smith, Maryland Department of Natural Resources, oral commun., 2003) within geomorphic transition areas, such as the boundary between the Piedmont and Coastal Plain Physiographic Provinces. The relevance of localized changes in sediment conveyance within drainage networks is watershed-specific. Misinterpretations can promote improper river-corridor management strategies (Prestegaard and others, 2000). 
Considering management timeframes, most bottomlands, especially those on the Coastal Plain, exhibit net aggradation through sediment deposition from two initially distinct sources: (1) runoff from adjacent uplands (riparian buffer) and (2) streamflow during inundation of bottomlands (riparian retention). Geomorphic analyses (Leopold and others, 1964; Jacobson and Coleman, 1986; Kleiss, 1996) verify that riparian retention of sediment is a common and important fluvial process. Unfortunately, retention time of sediment may be the most poorly understood and generally unquantified aspect of sediment budgets (R.B. Jacobson, U.S. Geological Survey, written commun., 1996). Johnston (1991) found only four published accounts of vertical accretion rates or mass accumulation for mineral fines in the United States for any type of wetland. More recently, wetland vertical accretion rates were reported by Hupp (2000) for West Tennessee, eastern Arkansas, South Carolina, North Carolina, and along tributaries to the Chesapeake Bay in Maryland and Virginia (table 4.1).

Researchers are investigating several tributaries of the Chesapeake Bay in an effort to understand sediment and associated contaminant storage and transport pathways in various hydrogeomorphic settings. Extensive riparian wetlands within the Coastal Plain regions of the bay may trap as much as $70,000 \mathrm{~kg} \mathrm{yr}^{-1}$ of sediment along a 2-km reach (Hupp and others, 1993). Several monitoring sites have been established along the
Chickahominy, Pamunkey, Mattaponi, Piankatank, Patuxent, Choptank, and Pocomoke Rivers, as well as other smaller tributaries. In addition to monitoring, long-term tree-ring data and short-term artificial marker horizons are being used to document net sediment deposition rates. Radioisotopic techniques also are being applied to track sediment sources and estimate poorly understood sediment retention times.

Initial results from both short- and long-term data indicate that substantial amounts of sediment are deposited at all the monitoring sites at rates exceeding $1 \mathrm{~mm} \mathrm{yr}^{-1}$ (fig. 4.1). Sedimentation rates are highest where alluvial (brownwater) streams receive runoff from either agricultural or urban areas with high loads of suspended sediment. The Choptank and Pocomoke Rivers, which originate on the Coastal Plain and Delmarva Peninsula, have relatively high sedimentation rates for blackwater (highly organic) rivers, however, the sediment loads usually are low. These rivers would normally have tea-stained, but generally clear water color. However, because these rivers experience considerable channelization ${ }_{\iota}$ sediment has been mobilized from drainage ditches and the main channel. Therefore, these rivers act more like pipelines than rivers that have functioning riparian areas.

It may seem intuitive that as sediment-laden flow leaves the main channel and enters a forested wetland, velocities slow because of the hydraulically rough nature of the forested bottom (also a

\section{Table 4.1. Mean sediment deposition rates for Coastal Plain rivers}

[Data from dendrogeomorphic analyses. The Cache River was investigated twice in different studies and locations.]

\begin{tabular}{|c|c|c|c|}
\hline River & Type & $\begin{array}{l}\text { Mean sediment } \\
\text { deposition rate } \\
\text { (millimeters } \\
\text { per year) }\end{array}$ & Authorship and date \\
\hline Hatchie, Tennessee & Alluvial & 5.4 & Bazemore and others (1991) \\
\hline Forked Deer, Tennessee & Alluvial & 3.5 & Bazemore and others (1991) \\
\hline Chicahominy, Virginia & Alluvial & 3.0 & Hupp and others (1993) \\
\hline Obion, Tennessee & Alluvial & 3.0 & Bazemore and others (1991) \\
\hline Patuxent, Maryland & Alluvial & 2.9 & Schening and others (1999) \\
\hline Cache, Arkansas & Alluvial & 2.7 & Hupp and Schening (1997) \\
\hline Roanoke, North Carolina & Alluvial & 2.3 & Hupp and others (1993) \\
\hline Cache, Arkansas & Alluvial & 1.8 & Hupp and Morris (1990) \\
\hline Wolf, Tennessee & Alluvial & 1.8 & Bazemore and others (1991) \\
\hline Mattaponi/Pamunkey, Virginia & Alluvial & 1.7 & Schening and others (1999) \\
\hline Coosawhatchie, South Carolina & Blackwater & 1.6 & Hupp and Schening (1997) \\
\hline Choptank, Maryland & Blackwater & 1.5 & Schening and others (1999) \\
\hline Pocomoke, Maryland & Blackwater & 1.5 & Hupp and others (1993) \\
\hline
\end{tabular}




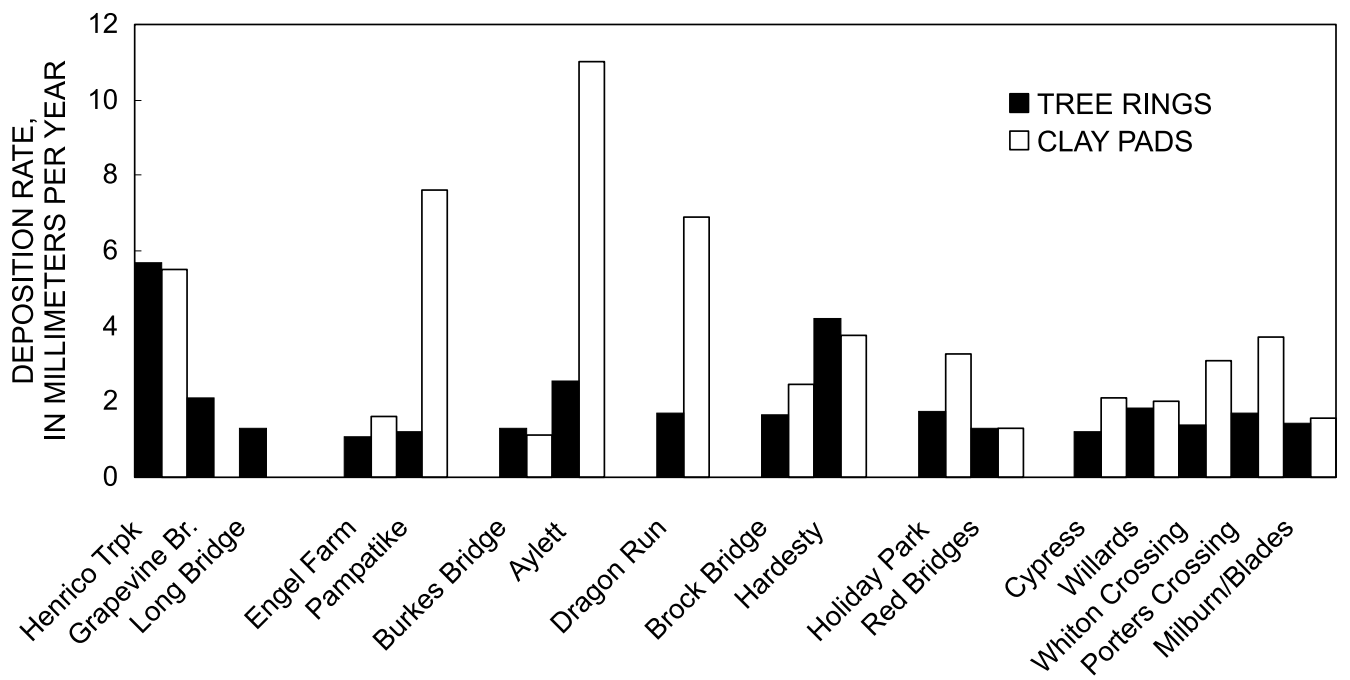

Figure 4.1. Sedimentation rates from tree-ring and clay pads along selected Chesapeake Bay tributaries. Rates from clay pads may be exaggerated by lack of compaction and non-decayed organic material.

dramatic increase in wetted perimeter) and consequently sediment is deposited (Kleiss, 1996). Yet, until recently, few attempts have been made to quantify sediment deposition in any wetland system. Even fewer published accounts describing factors affecting local variation in deposition rate are available (Hupp and Schening, 1997; Hupp, 2000). The amount of suspended fine material available strongly influences deposition potential. Variation in local elevation across a bottomland and correlated length of hydroperiod (length of time flow is in wetland) also have been cited as important factors affecting deposition rate (Hupp and Morris, 1990; Hupp and Bazemore, 1993; Kleiss 1993, 1996). Several other interrelated factors may play an important role in local sediment deposition, including flow velocity, distance of flowpath from main channel, hydraulic connection to main channel, internal flowpaths, ponding (typically in backswamps or behind levees), roughness from standing vegetation and large woody debris, and beaver activity.

In summary, the trapping of sediment and associated contaminants in the riparian and floodplain zones of lowland (Coastal Plain) tributaries is a major water-quality function of these systems. This function will play an increasingly important role in the retention of sediment entering the bay. Activities such as channelization, which limits the amount of contact between streamflow and the riparian zone, will compromise the natural ability of the streams to retain sediment and contaminants.

\section{$\underline{\text { Reservoirs }}$}

The large numbers of dams and impoundments that have been built in the bay watershed have a significant effect on river sediment loads. Dams interrupt the "natural" down-river flow of sediment. Although most water eventually is released downstream, sediment is effectively captured behind dams. In fact, many reservoirs trap at least half the sediment annually flowing into them until reaching sediment storage capacity (Meade and others, 1990). After a reservoir reaches its sediment-storing capacity, sediment loads flowing downstream "through" the reservoir will increase and approximately equal that amount transported into the reservoir.

Sedimentation in any reservoir can be evaluated using bathymetric data or direct calculation with consideration of trapping efficiency. Costa (1975) estimated that one-third of total sediments erosion in Loch Raven Reservoir Basin (located in Maryland) since European colonization left the basin and two-thirds was still in storage. He based these conclusions on an analysis of the bathymetric conditions in the reservoir at the downstream end of the drainage network. Reservoir sedimentation also was measured by Ortt and others (2000) in the 
Gunpowder River watershed and by Ocean Surveys, Inc. (1997) in the Upper Patuxent River, both of which are in the Piedmont Physiographic Province of Maryland. Accretion rates measured in Loch Raven and Pretty Boy Reservoirs average 1.4 to $1.5 \mathrm{~cm} \mathrm{yr}^{-1}$, resulting in a total accumulation of 10,100 and $8,740 \mathrm{~m}^{3} \mathrm{yr}^{-1}$ (Ortt and others, 2000). Ocean Surveys, Inc. found that a third reservoir in Maryland (Tridelphia) was accumulating approximately 50,000- $\mathrm{m}^{3} \mathrm{yr}^{-1}$ since its construction in 1942. In all three studies, the relation between reservoir sedimentation and watershed sediment yield was not formally developed.

\section{Susquehanna River Reservoirs}

During floods, large amounts of sediment and nutrients are transported into the reservoir system, and, along with sediments and nutrients already trapped in the reservoirs, are available for deposition, resuspension, scour, and transport downstream. However, scour of sediment from reservoirs during floods increases the storage capacity of the reservoirs. For example, the three most recent floods-June 1972, September 1975, and January 1996-removed about 36 million tons of sediment from three reservoirs in the lower Susquehanna River Basin (Langland and Hainly, 1997).

The largest dams in the bay watershed are in the lower reaches of the Susquehanna River.

A reservoir system, consisting of Lake Clarke, Lake Aldred, and Conowingo Reservoir, forms behind three consecutive hydroelectric dams (fig. 4.2). Safe Harbor Dam, built in 1931, forms Lake Clarke.

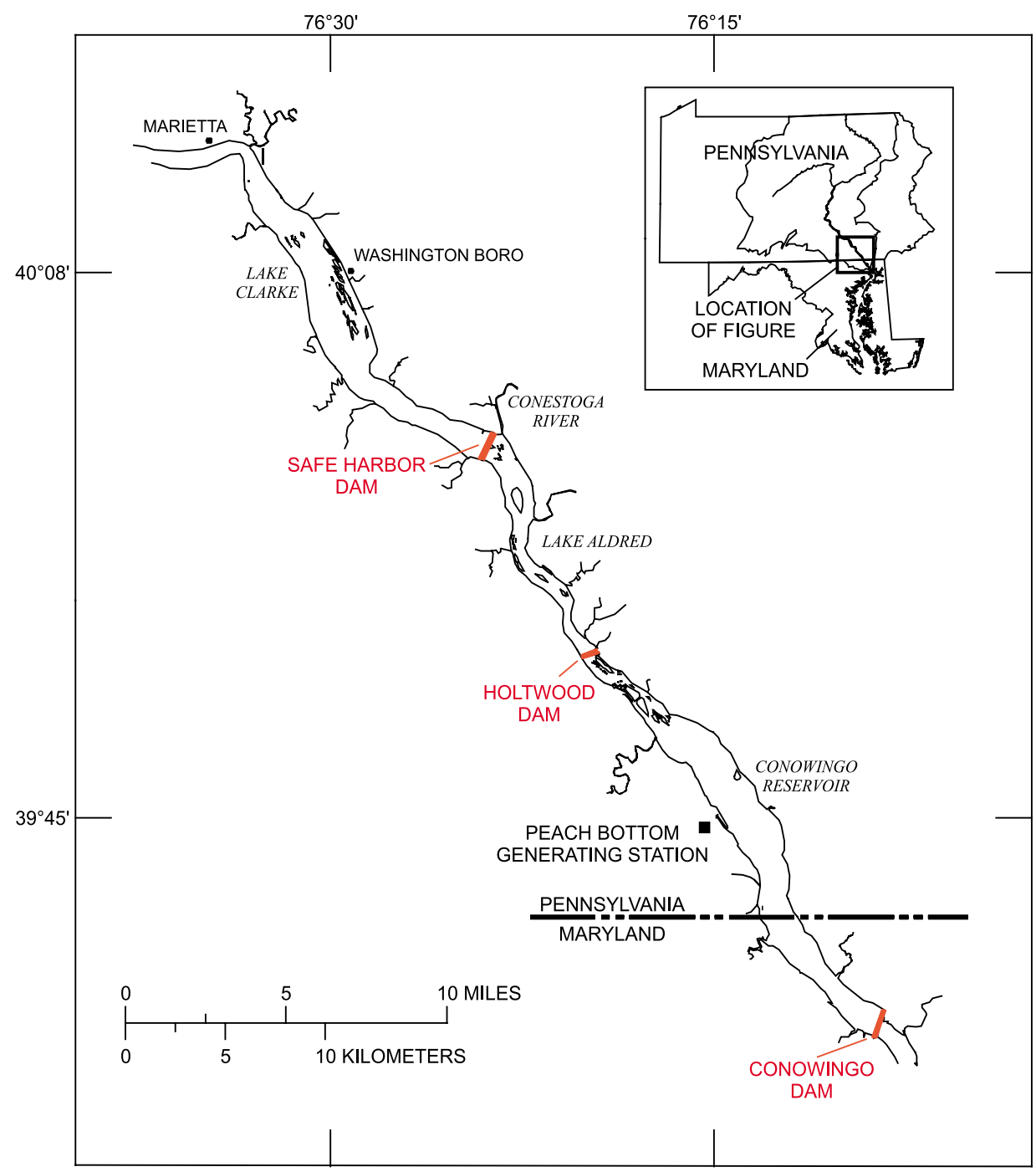

Figure 4.2. Location of three hydroelectric dams and reservoirs in the Lower Susquehanna River Basin. 
Holtwood Dam, built in 1910, forms Lake Aldred and is the smallest of the three reservoirs.

Conowingo Dam, built in 1928, is the largest and furthest downstream reservoir.

Since their construction, the reservoirs have been filling with sediment and sediment-associated nutrients. The upper two reservoirs have reached capacity and generally no longer trap large amounts of sediments and nutrients. However, Conowingo Reservoir has not reached capacity and currently is trapping about 2 percent of nitrogen, 40 percent of phosphorus, and 50-

70 percent of suspended sediment that would otherwise be discharged to the Chesapeake Bay (Langland and Hainly, 1997).

Long-term discharge records are kept by the power-plant operators. Since 1985, continuous discharge and water-quality data has been collected at Conowingo and Marietta by the USGS and the Susquehanna River Basin Commission (SRBC). In 1990, 1993, and 1996, the USGS determined the water depth to sediment in the reservoirs in an effort to calculate the remaining sediment-storage capacity in the reservoir system and to estimate when the reservoirs will reach sediment-storage capacity (Langland and Hainly, 1997). The 1996 data collection followed a major flood in the Susquehanna River Basin. These studies showed that although the Conowingo Reservoir is not yet full of sediment, little space remains to be filled. The cross-sectional areas of available space for nutrient and sediment storage have changed from 1928 to 1996 and the probable cross-sectional area when the reservoir is at full sediment-storage capacity is shown in figure 4.3. From the upper end of the reservoir to about $28,000 \mathrm{ft}$ upstream from the dam, the reservoir has very little sediment-storage capacity remaining; the capacity from $28,000 \mathrm{ft}$ downstream to the dam was reduced greatly between 1928 and 1996. As a result of scour during the January 1996 flood, storage capacity in the Conowingo Reservoir increased approximately 1,600 acre- $\mathrm{ft}$, which is equivalent to 2.4 million tons of sediment. About 29,000 acre-ft remain to be filled, or about 42 million tons of sediment can be deposited, before the sediment-storage capacity is reached (area in red, fig. 4.3).
Estimating the time remaining until the reservoir reaches sediment-storage capacity is difficult because the amount of sediment transported and deposited in the reservoirs depends on factors such as land-use and management practices, rainfall, and large storm events. Despite these uncertainties, the reservoirs currently are estimated to reach storage capacity in 20-25 years. When this occurs, the amount of sediment and nutrients transported to the bay by the Susquehanna River will equal that amount delivered into the reservoir system. If all other conditions remain constant, and assuming 60-percent sediment trapping efficiency, this will result in a 2-percent average annual increase in the nitrogen load, a 40-percent average increase in the phosphorus load, and a 150-percent average annual increase in the suspended-sediment load. After capacity has been reached, a greater increase in the annual loads of nutrients and sediment transported to the Chesapeake Bay will take place during major scour-producing flood events. A task force, commissioned by the Susquehanna River Basin Commission, composed of scientists, individuals from private industry, and lawmakers, recently addressed the issue of sediment retention in the reservoirs and published a list of recommendations dealing with sediment issues in the watershed and bay (Susquehanna River Basin Commission, 2000). 


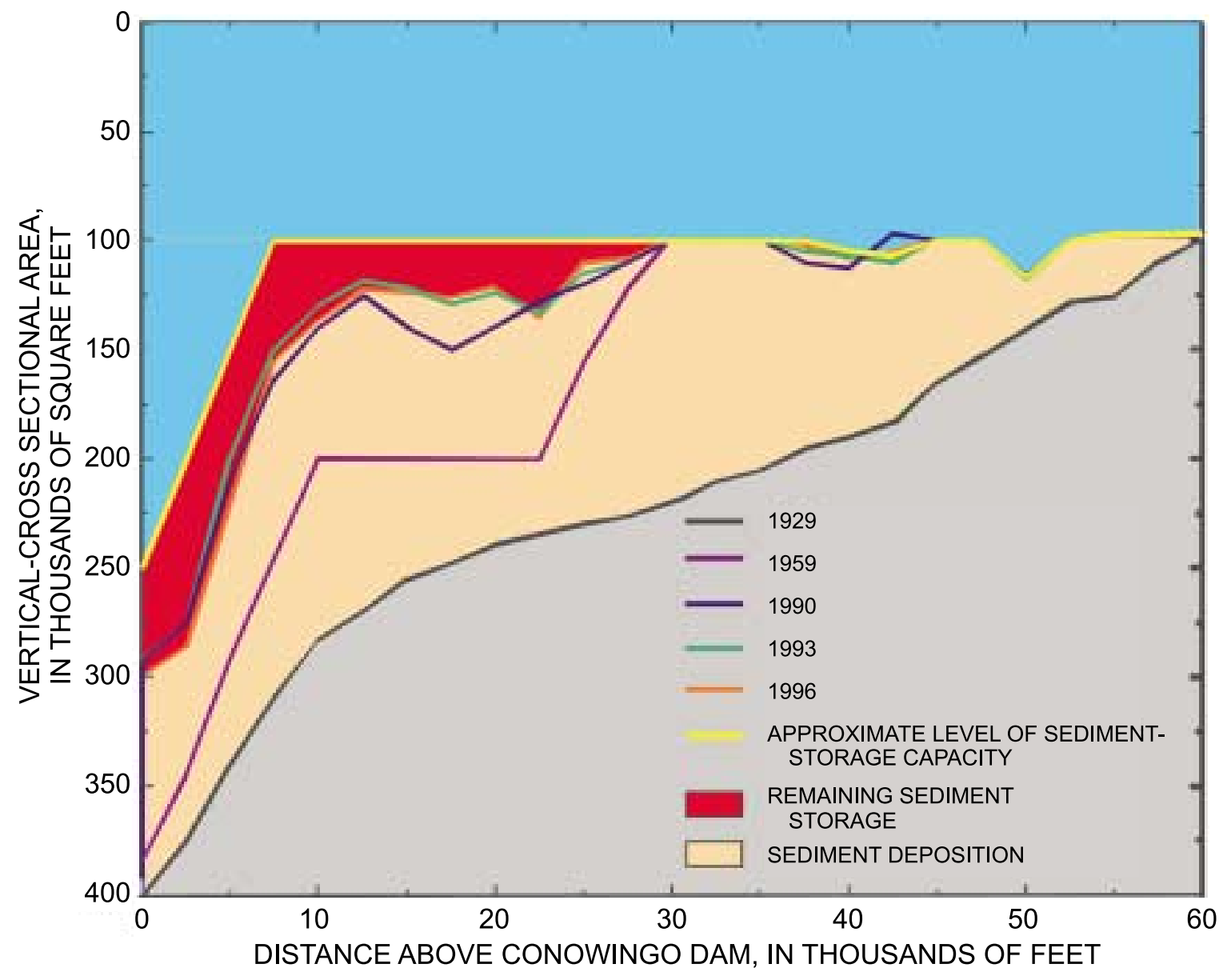

Figure 4.3. Change in Conowingo reservoir sediment-storage capacity, 1929-1996. 


\section{CHAPTER 5. ESTUARINE SEDIMENT SOURCES}

\author{
by Thomas Cronin, ${ }^{1}$ Jeff Halka, ${ }^{2}$ \\ Scott Phillips, ${ }^{1}$ and Owen Bricker ${ }^{1}$
}

This chapter describes the sources of sediments entering the Chesapeake Bay estuary from various riverine, oceanic, biogenic, shoreline, and atmospheric sources. The chapter begins with an integrated look at contributing sources to the estuary, then proceeds into more detailed descriptions of the individual sources. Because of the integrated nature of the watershed-bay system, many of the processes described here are necessarily related to those covered in the prior chapter on watershed sedimentary processes. Following this section on sediment sources, the chapter describes sediment transport to and within the estuary, deposition (storage) and sedimentation in the estuary, and secondary resuspension of sediment in the bay and its tributaries.

\section{Estimates of Major Sediment Sources}

The major sources of fine-grained sediment to the estuary are from external and internal sources. The three major external sources include the above-Fall Line watersheds, below-Fall Line watersheds, and oceanic inputs. Two major internal sources are from shoreline erosion and biogenic productivity. Few complete studies on the estuary that summarize the relative contribution of these sources have been conducted. The best available data to assess the approximate relative contribution of these sources on an estuary-wide basis, without accounting for spatial or temporal variability or transport within the estuary, have been compiled and are presented in this chapter.

The Fall Line watershed inputs were derived from the River Input Monitoring Station data for the 1989-99 period and average inputs totaled 4.27 million metric tons per year (Langland and others, 1999). It was assumed that the great majority, if not all, of the sediment supplied at the Fall Line was fine-grained silts and clays. The watersheds included in this total were the Susquehanna, Potomac, James, Patuxent, Mattaponi, Pamunkey, Appomatox, and Choptank. Tributaries on the Eastern Shore that were not represented include

\footnotetext{
${ }^{1}$ U.S. Geological Survey.

${ }^{2}$ Maryland Geological Survey.
}

the Chester, Nanticoke, Wicomico, and Pocomoke Rivers. On the Western Shore, the major tributary not included was the Patapsco River.

The below-Fall Line loads have been estimated for few tributaries including the Potomac (Miller, 1987), Choptank (Yarbo and others, 1981; 1983), Rhode (Pierce and Dulong, 1977) and Patuxent (Roberts and Pierce, 1974; 1976) Rivers. The amount from these four studies totaled 0.9 million metric tons per year, all of which was assumed to consist of fine-grained sediments. No attempt was made in this effort to estimate below-Fall Line loads from tributaries that had not been studied (see Watershed Model discussion in Chapter 7).

Oceanic input of fine-grained sediment was estimated from the works of Schubel and Carter (1976) and Hobbs and others (1992). The former utilized a conservative salt-budget but did not actually measure sediment input. The latter determined the deficit of deposited sediment throughout the bay on the basis of comparisons of historical bathymetry and ascribed the difference to oceanic input, 14 percent of which was determined to be fine-grained sediments. Examining these two studies produced a total estimate of the oceanic input at 1.14 million metric tons per year of fine-grained sediments to the bay.

Input of sediment from fastland (above water, mean tide) shoreline erosion and associated nearshore (below water, mean tide) erosion (discussed in detail later in this chapter) was estimated using data from the USCOE Shoreline Erosion Study (1990), which summarized the results separately for Maryland (Kerhin and others, 1988) and Virginia (Byrne and others, 1982). Estimates of the relative amounts of fine-grained and coarsegrained components of shoreline erosion were derived from the shoreline studies in Virginia (Ibison and others, 1990; 1992). Details of the analyses can be found in the Shoreline Erosion section of this chapter. Fastland erosion alone was determined to supply 3.60 million metric tons per year of fine-grained sediment from the shorelines of the bay; including the associated nearshore erosion increased this number to 8.42 million metric tons per year.

The relative contribution of these major sediment source components to the entire Chesapeake Bay estuary is shown in figure 5.1. It is recognized that there are areas where data is lacking, including lack of river input monitoring measurements for all tributaries, relatively few below the Fall Line 


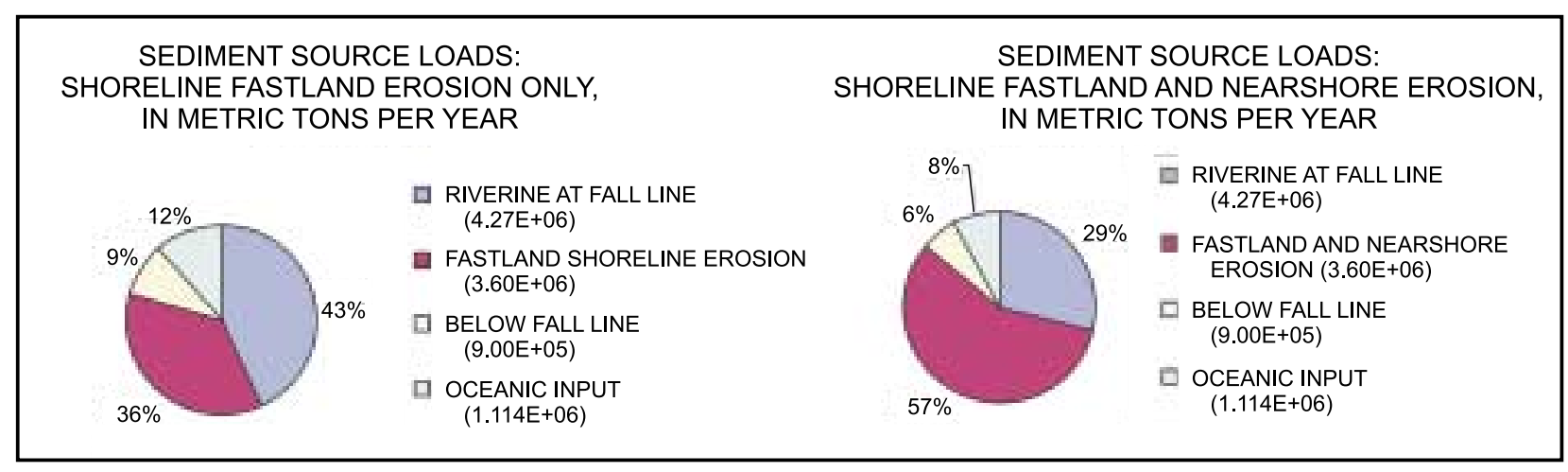

Figure 5.1. Relative contributions of sediment sources to the estuary with fastland (above tidal water) erosion (left) and with fastland and nearshore (below tidal water) erosion (right). (Based on data in chapter 7, table 7.2, and U.S. Army Corps of Engineers, 1990)

tributary suspended sediment estimates, internal biogenic productivity data are lacking, and oceanic and shoreline inputs are only roughly estimated. Biogenic productivity has been shown to be significant in certain areas of the bay in certain seasons (Biggs, 1970) and needs to be more fully addressed in future studies. These results also may not include the effects of extreme climatic events. However, these results indicate the major sources of fine-grained sediments and will provide useful information in devising management strategies. As shown in figure 5.1, the above-Fall Line and shoreline erosion inputs are the dominant contributors of fine-grained sediment, together supplying 79 to 86 percent of the total load. Fastland shoreline erosion (36 percent) and Fall Line Riverine input (43 percent) are roughly sub-equal if associated nearshore erosion inputs are not included (left graph). However, if the nearshore component of shoreline erosion is included in the total, the shoreline contribution dominates all other sources with an input of 57 percent of the total (right graph).

Although shoreline protection measures may be an important component of future management strategies, it may be difficult to measurably reduce the input because of the dispersed nature of the source and the difficulties in reducing the nearshore erosion component. Construction of hard erosion-control devices in areas of high fastland erosion rates may increase erosion in the adjacent nearshore area because of wave reflection and refraction, thus compounding the problem of sediment supplied from shoreline erosion.

\section{Watershed Sources}

Sediment eroded from the watershed is delivered to the bay and its tidal tributaries through river transport. Much of the sediment transported in the large rivers (Susquehanna, Potomac, and James) initially is deposited near the Fall Line, which refers to the zone where a change in topography separates the Piedmont Physiographic Province from the Coastal Plain. This zone generally represents the limit of the tidal influence of rivers and tends to coincide with the area where the harder crystalline rocks of the Piedmont Physiographic Province and the softer unconsolidated rocks of the Coastal Plain Physiographic Province overlap. The large amount of deposition near the Fall Line occurs due to an abrupt reduction in stream gradient (lesser slope so less stream velocity) and influence from tides of the bay. Above the Fall Line, rivers are typified by a high load of inorganic suspended sediments and at times are the dominant source of TSS that results in reduced water clarity in the upper tidal tributaries of the bay. In contrast, many rivers that originate below the Fall Line in the Coastal Plain Physiographic Province, where the stream gradient is low, transport relatively smaller amounts of mineral sediments but contain high levels of dissolved organic material. Of the sediment generated in watersheds, up to 80-percent is trapped for a period of time along streams before reaching saltwater (Costa, 1975; Trimble, 1981; Herman, 2001). This sediment may take years to centuries to be transported to the bay because of continual deposition and resuspension in stream corridors. 
In the mid-1980s, the USGS Chesapeake Bay River Input Monitoring (RIM) Program was established to quantify loads and long-term trends in concentrations of nutrients and suspended material entering the tidal part of the Chesapeake Bay watershed from its nine major tributaries (fig. 5.2). From 1985 to 2000, the two rivers with the highest annual sediment load were the Potomac River $(1,932,000$ tons) and the Susquehanna River (1,154,600 tons) (fig. 5.3A). During this period, the two rivers with the highest sediment yield were the Rappahannock River (329 tons $\mathrm{mi}^{-2}$ ) and the Potomac River (167 tons $\mathrm{mi}^{-2}$ ) (fig. 5.3B). Monthly and annual trends are estimated for sediment concentration and load using samples collected once a month and during storm events. Sediment concentration and streamflow are then used in a statistical model to estimate the load of sediment entering the tidal reach of each river.

The long-term annual average of suspended material contributed by the nine RIM basins is approximately 4.3 million tons $\mathrm{yr}^{-1}$. About 90 percent of this material came from the three largest rivers (Susquehanna, Potomac, and James) (fig. 5.4). Quantity of streamflow is the dominant factor transporting and delivering suspended loads from the watersheds to the estuary. Delivered loads varied from 12.2 million tons $\mathrm{yr}^{-1}$ (1996) to 0.71 million ton $\mathrm{yr}^{-1}$ (2001). A severe drought, which occurred over much of the bay watershed from 1999 to 2001, resulted in an annual average load of 780,000 tons $\mathrm{yr}^{-1}$, about 80 percent below the normal long-term average. Although the total loads in 1990-2001 were less because of lower rainfall and lower streamflow, the relative contribution of the major rivers was similar to the long-term average (Langland and others, 1995). Long-term trends in monthly loads (1985-2001) at the nine RIM sites indicate there had been no significant change. However, if the influence of streamflow is removed, the trend in monthly concentration shows a significant decrease at three sites and a significant increase at two sites.

Currently, there are no long-term monitoring data to estimate the load contributed from areas below the Fall Line. Computer simulations completed using the Chesapeake Bay watershed Model (discussed in Chapter 7) estimates an additional 1 million ton $\mathrm{yr}^{-1}$ of sediment enters the estuary from the unmonitored Coastal Plain region, with minor inputs from the Piedmont region below the Fall Line monitoring stations.

\section{Shoreline Erosion}

Chesapeake Bay formed in response to rising sea level following the last major advance of the Pleistocene glaciers. Approximately 18,000 years ago, ocean levels in the mid-Atlantic region were approximately $400 \mathrm{ft}$ lower than at present and by approximately 8,000 years ago had reached a level sufficient to begin inundation of the deeply incised valley cut by the Susquehanna River and tributaries (Colman and others, 1990; 2001; Cronin and others, 2000). Continued sea-level rise first flooded the deep narrow river valleys and then the surrounding gently sloping lands of the Coastal Plain Physiographic Province. As the water level rose in the bay, erosion of the unconsolidated sediments along its shorelines contributed to the expansion of the estuary. Because sea level continues to rise in the bay region at a rate of approximately 1.0 to $1.4 \mathrm{ft}$ per century, and because the rate may accelerate in the future as a result of global warming, shoreline erosion in response to the rising sea level is an important process ongoing in the bay.

The immediate cause of shoreline erosion is the action of waves on the sediments along the shore. Without a rising sea level, a dynamic equilibrium state would be reached in which shoreline erosion would decrease dramatically from the present rate. However, when sea level is rising, the action of waves reaches further inland over time to continue the process of shoreline erosion.

Erosion of the shorelines results in an immediate introduction of sediment to the estuarine waters. Shoreline erosion usually is described in terms of its location. The relation between fastland erosion and associated nearshore erosion is shown in figure 5.5 .

The rate of erosion at any particular location is dependent on a number of factors that include land use, sediment composition, orientation of the shoreline, bathymetry of the offshore region, and the local wind fetch for generation of waves. The relative importance of these factors in determining the erosion rate is difficult to assess for the bay as a whole because each factor is highly variable both spatially and temporally. Historical shorelines have been mapped in Maryland and Virginia and erosion rates derived from these shorelines integrate the dominant processes that have driven erosion at a particular location.

Historical erosion rates mapped in Maryland (Conkwright, 1975) and Virginia (Byrne and Anderson, 1977) were used by the USCOE in 1990 


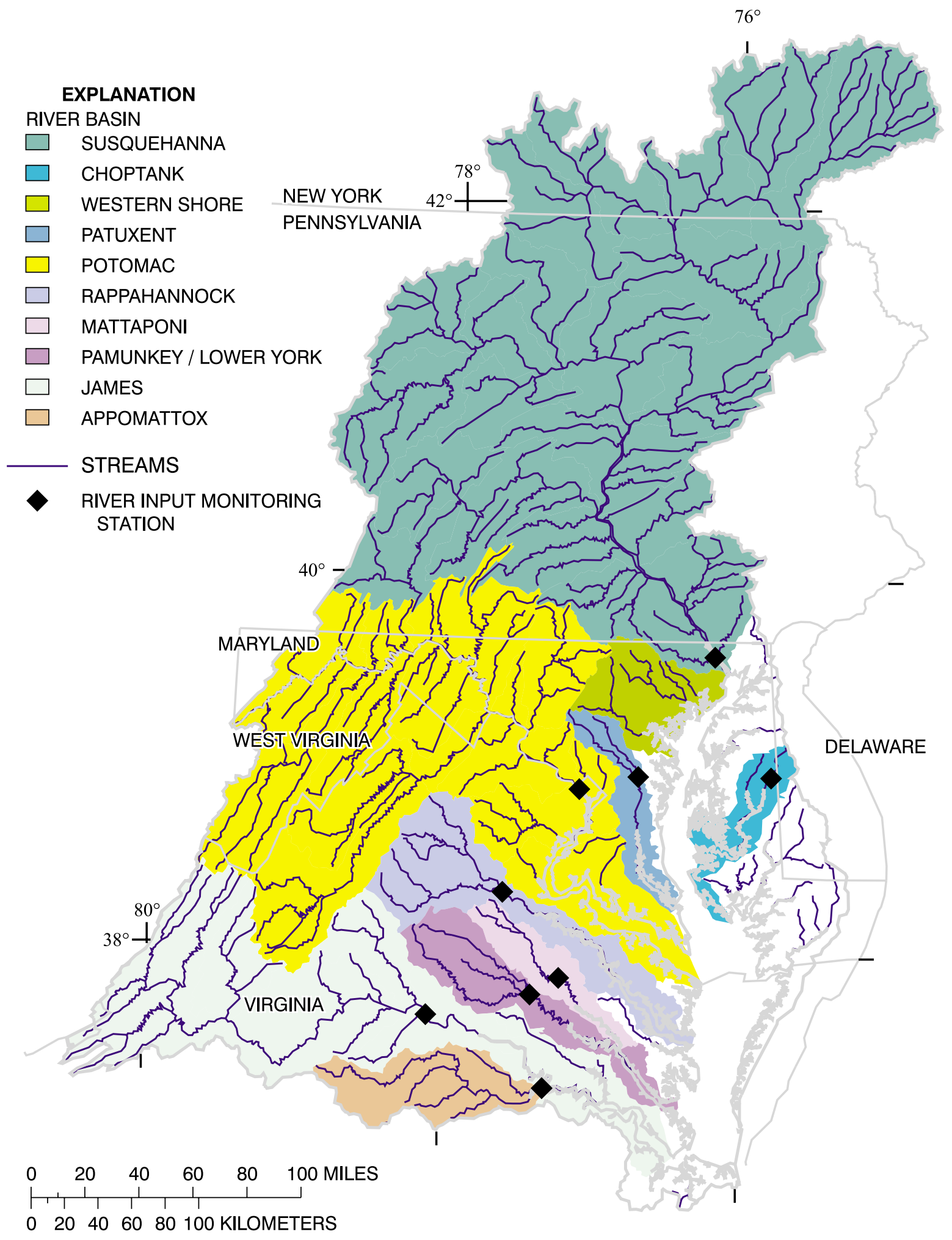

Figure 5.2. Location map of the nine River Input Monitoring (RIM) Sites. 

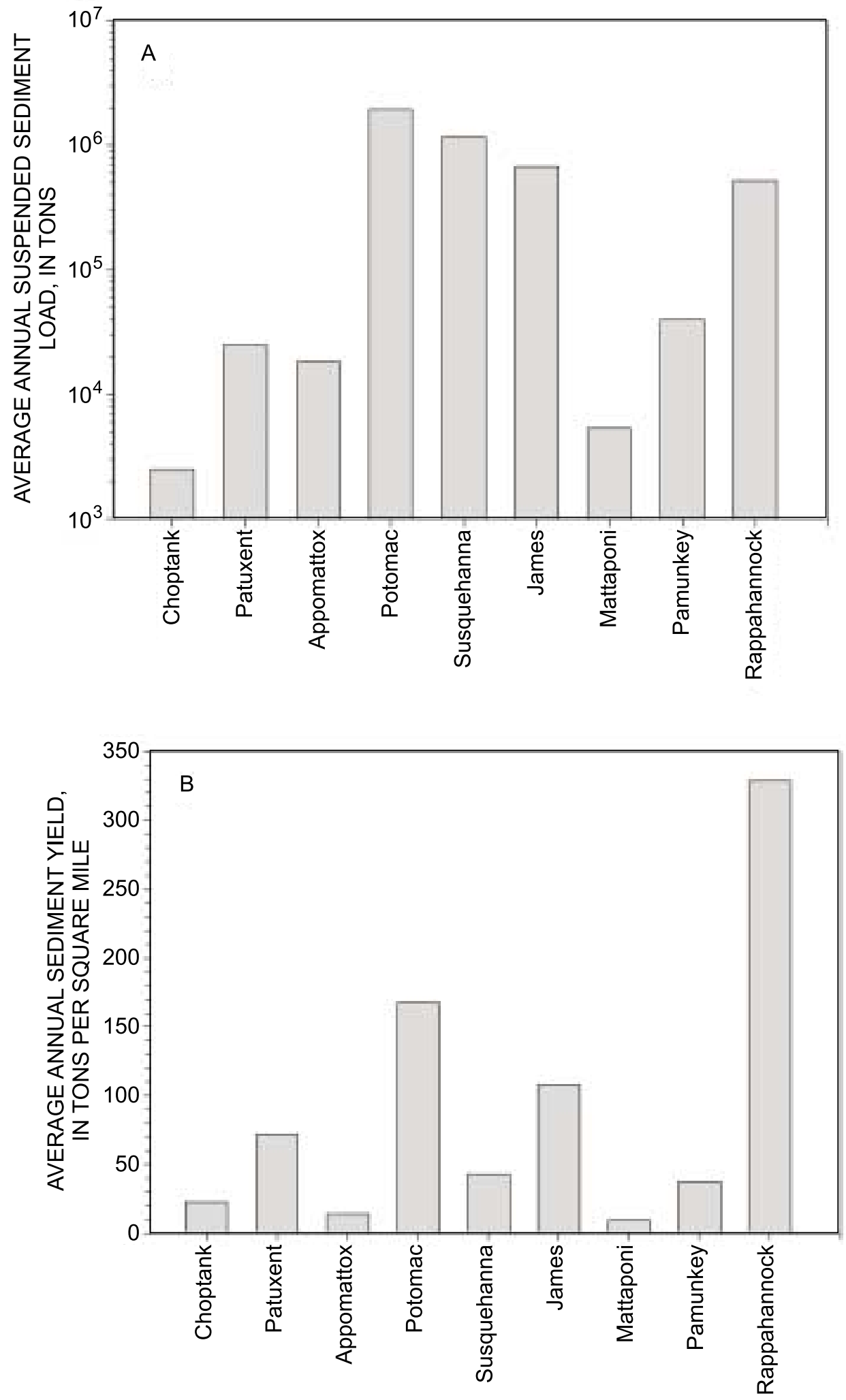

Figure 5.3. River Input Monitoring station sediment data, 1985 to 2000. (A) Average annual suspended-sediment load (log scale) and (B) average annual sediment yield. Most annual loads were computed on the basis of suspended sediment. 


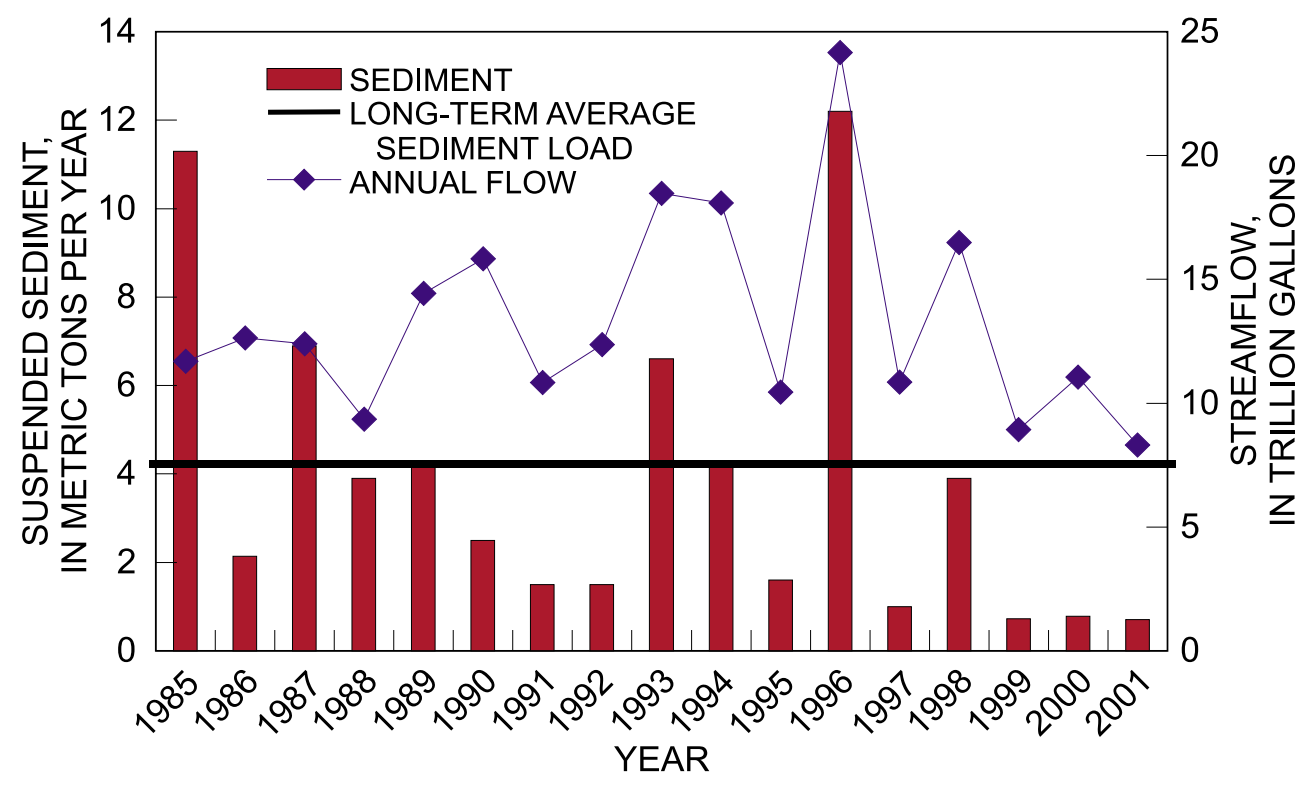

Figure 5.4. Combined annual suspended-sediment loads and relation to annual flow for the Susquehanna, Potomac, and the James Rivers near the Fall Line.
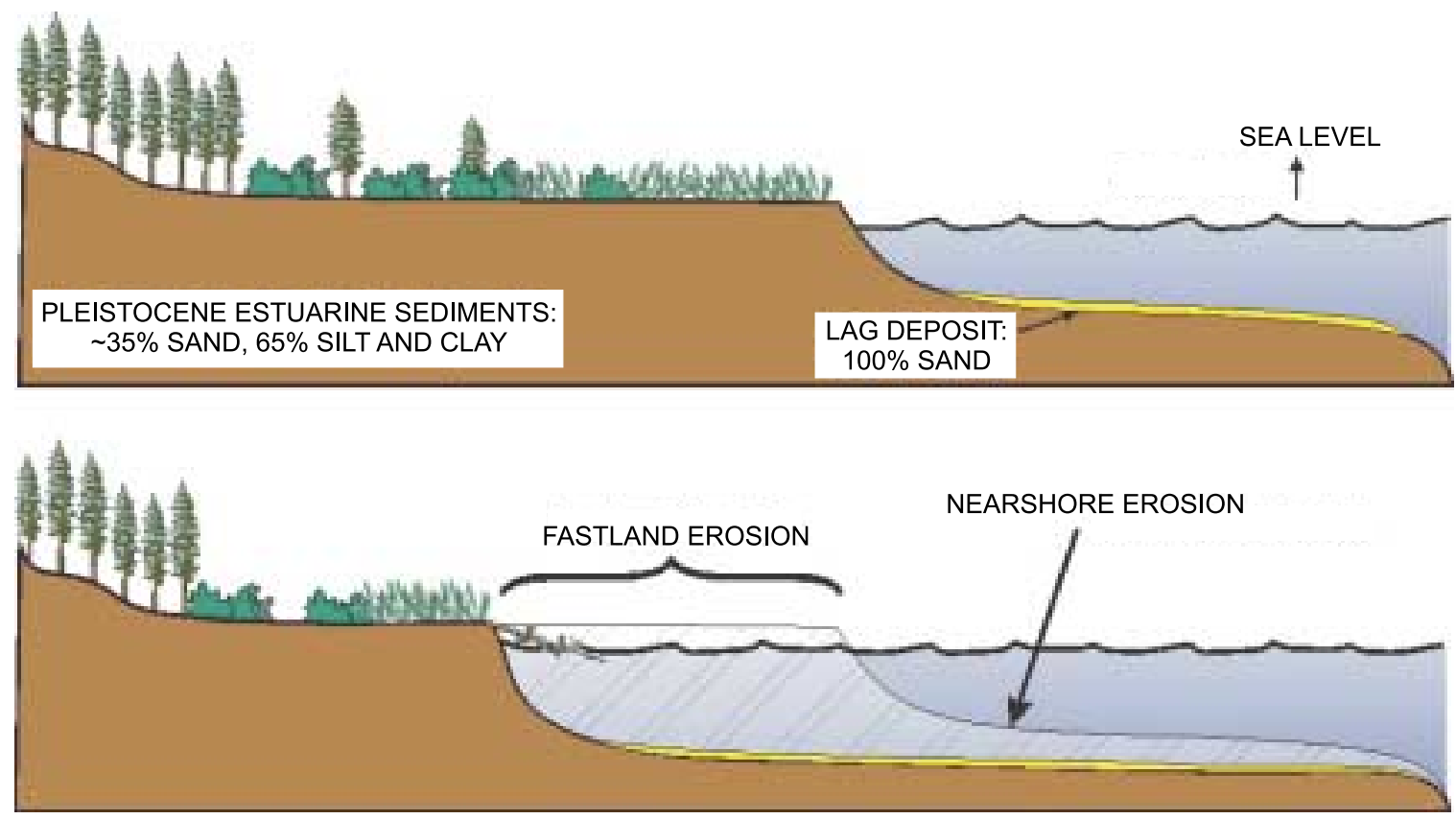

Figure 5.5. Relation between fastland (above tide) erosion and nearshore (below tide) erosion. 
to estimate the magnitude of the erosion rate baywide (U.S. Army Corps of Engineers, 1990) and to develop an estimate of a bay-wide sediment budget (Hobbs and others, 1992). The Maryland erosion rate maps (2003) currently are being updated to include a recent (about 1990) shoreline along with the historical shorelines. These maps will provide updated estimates of shoreline change for the Maryland part of the bay.

The USCOE (1990) report indicated that shoreline erosion was not limited to fastland erosion but also included an envelope of sediment that is eroded to the base of wave action in the nearshore zone off the eroding shoreline. Analysis of historical bathymetric data by the USCOE indicated that this depth of erosion extended out to an average present-day (2003) 8-ft water depth. Including these nearshore sediments in the volume derived from fastland shoreline erosion increased the overall total from $4.7 \times 10^{6}$ yards $^{3} \mathrm{yr}^{-1}$ to $11.0 \times 10^{6}$ yards $^{3} \mathrm{yr}^{-1}$. Using similar bulk density values and percentages of sand as for fastland erosion, the total yield to the estuarine waters from the fastland and nearshore erosion increases to $12.6 \times 10^{6}$ metric tons $\mathrm{yr}^{-1}$, of which $8.4 \times 10^{6}$ metric tons is fine-grained silt plus clay. With fastland shoreline protection, nearshore erosion will continue because of wave action. Hardening of the shoreline with bulkheads has been shown to increase erosion of the nearshore bottom through reflection of wave energy.

Values for bulk density of eroding shorelines have differed in various reports produced for the bay. Kerhin and others (1998) utilized densities obtained from the Maryland Department of Transportation that ranged from $1.67 \mathrm{~g} \mathrm{cc}^{-1}$ for silt clays to $1.92 \mathrm{~g} \mathrm{cc}^{-1}$ for sands; the average was $1.78 \mathrm{~g} \mathrm{cc}^{-1}$. Byrne and others (1982) and Hobbs and others (1992) reported using values that were consistent with those of Kerhin and others (1998). The shoreline erosion studies of Ibison and others (1990; 1992) cited soil scientists in using a bulk density measurement of $1.5 \mathrm{~g} \mathrm{cc}^{-1}$ to convert shoreline erosion volumes to mass. Biggs (1970) used mineral grain densities in calculating a sediment budget for the northern Chesapeake Bay, which at 2.65 to $2.72 \mathrm{~g} \mathrm{cc}^{-1}$ would overestimate the percentage of sediment derived from fastland shoreline erosion. Direct measurements of dry bulk densities at a number of sites in the Maryland portion of the Chesapeake Bay yielded an average value of $1.5 \mathrm{~g} \mathrm{cc}^{-1}$ (Hill and others, oral commun., 2003). Marsh sediments have much lower dry bulk den- sity values that center at approximately $0.5 \mathrm{~g} \mathrm{cc}^{-1}$ (Anderson and others, 1977, Stevenson and others, 1985). The range in values reported for bulkdensity measurements is due in part to natural variability that may be confounded by measurements made on different levels in the strata and measurement of simple bulk density rather than dry bulk density. Moisture incorporated in the sediment, while adding mass, is not relevant to the measurement of sediment yield. The Ibison and others $(1990 ; 1992)$ value of $1.5 \mathrm{~g} \mathrm{cc}^{-1}$ for bank erosion is approximately mid-range in the values reported, and is corroborated by the direct dry measurements of Hill and others (oral commun., 2003). This value currently is being used in the CBP modeling effort. It thus represents a reasonable average value for fastland shoreline density. Using this value, the resulting load to the Chesapeake Bay from shoreline erosion is $5.4 \times 10^{6}$ metric tons $\mathrm{yr}^{-1}$ (more discussion in chapter 7).

However, the Bay Model uses a constant shoreline erosion rate, allowing calibration to sediment concentrations on the scale of the Chesapeake Bay estuary, but it is not spatially variable and does not account for nearshore erosion. In addition, to compensate for lack of a resuspension simulation, modeled shoreline loads remain in suspension an unrealistic length of time. Therefore, the model may be underestimating the variable input from shoreline load and could be overestimating the influence of shoreline erosion on water clarity in the shallow-water zone.

Not all shoreline erosion is detrimental. It is also important to note the necessary and beneficial functions of sediments within estuaries. Sediment is critical to maintaining the elevations of tidal wetlands, particularly in response to sea level rise. An important source of sediment to salt marshes is overbank flooding, which generally delivers suspended fine sediments to the marsh substrate. Coarse material of upland origin, and suspended coarse sediment in littoral cells are responsible for the development and maintenance of bay dunes and beaches. Dunes, beaches, and wetlands are critical habitats for a diverse array of estuarine flora and fauna. Depending on the grain size of the eroding shoreline, the introduced sediments can provide valuable habitat in the form of sandy beaches, or conversely, fine-grained clays that can remain suspended for long periods in the water with consequent negative effects on the ecosystem. The wave action also serves to transport sediments along the shoreline in a down-drift direction, and 
can resupply beaches along the shore. In some locations in the bay, the rate of supply of coarser sediments can produce areas where the shoreline has accreted over recent, relatively short time periods. However, erosion is the dominant effect of the combined action of rising sea level and waves.

Sediment derived from shoreline erosion includes not only fine-grained silts and clays that can remain suspended in the water column for extended periods and result in significant light attenuation, but also includes sand- and gravelsized components that settle at the base of the eroding shore-forming beaches. These beaches can serve to buffer the shoreline from the encroaching waves and rising seas while providing potentially valuable habitat that commonly is lacking in the Chesapeake. Thus, protecting the shorelines from erosion may have the unintended consequence of further eliminating critical habitat in the bay. In Virginia, the eroding shorelines consist of approximately 33-percent sand and gravel (Ibison and others, 1990; 1992). In Maryland, the percentage reported in mass calculations ( 35 percent) was similar (Kerhin and others, 1988). Recently, additional sampling in Maryland yielded an average bank composition of 47-percent sand and gravel (Hill and others, oral commun., 2003)). Thus, although estimates vary, at least one-third of fastland shoreline erosion contributes to nearshore sandy sediments (fig 5.5) that have little influence on light attenuation, although two-thirds, or $3.6 \times 10^{6}$ metric tons $\mathrm{yr}^{-1}$, has the potential to remain suspended in the water column.

\section{Oceanic Input}

Sedimentation in the southern part of Chesapeake Bay has been the subject of numerous detailed studies over the past 40 years. In the southern bay, large quantities of sediment are derived from inflow from the Atlantic Ocean continental shelf through the mouth of the bay because of tides and ocean currents and from coastal erosion of headlands along the bay margins (Harrison and others, 1967; Meade, 1969; Meade, 1972). The mouth of the bay is characterized by complex sedimentary processes that result from variations in the tidal prism, fluvial input to the estuary, storm conditions in the estuary and in the ocean, and mutually exclusive ebb- and flood-dominated channels (Ludwick, 1975). Estimates of sediment influx through the mouth have relied on bottomsediment sampling (Byrne and others, 1980), longterm averaging from geological and geophysical studies (Colman and others, 1988), mineralogical data (Berquist, 1986), and short-lived radioisotopic studies of sediment cores (Officer and others, 1984). This section discusses those aspects of sedimentation in the southern bay most relevant to issues of water clarity.

Studies of long-term sedimentation in the southern bay indicate that subsurface Holocene sediment is filling the former Susquehanna River channel (Colman and others, 1988). This suggests that the majority of sediment entering the bay through the mouth has been, and continues to be, relatively coarse sands. The historical southward progradation of the southern tip of the Delmarva Peninsula completely covering the pre-Holocene Susquehanna River channel at the mouth of the bay (Colman and others, 1990) attests to the southward movement of large quantities of sand along the Atlantic Coast of the peninsula. These sands not only extended the peninsula tip over the earlier location of the incised Susquehanna River channel, but sub-surface bedforms reveal the movement of large quantities around the peninsula tip and into the bay (Colman and others, 1988; Colman and Hobbs, 1987).

Analysis of successive bathymetric surveys conducted from the mid-1800s to the mid-1900s and analyses of bottom sediments show significant accumulations of sediment in the region of the mouth relative to other parts of the bay (Byrne and Anderson, 1977; Byrne and others, 1980; Kerhin and others, 1988; Hobbs and others, 1990; 1992). These studies suggest that the volume of sediment that has accumulated in the bay during the 18401940 period cannot be accounted for solely from shoreline erosion, biogenic production, and riverine input. The volume of sand-sized sediment exceeded the available sources by a factor of between 2.7 and 7.6. The range is dependent on the levels of confidence that were ascribed to the bathymetric changes observed in comparing the historical surveys. Most of this difference in the sand-sized fraction of quantifiable sediment was in the Virginia part of the bay. Finer-grained muds exceeded quantifiable sources by a factor of 2.4 , a value less than that for sands, but still large (see below). Consequently, Hobbs and others (1990) concluded that input of ocean-source sediment from the adjacent Atlantic Ocean into the mouth of the bay must be a significant source of the total sediment deposited in the bay. Examination of relatively long-term Holocene (10,000 year) depositional records for the main stem of the Chesapeake 
Bay also indicates that very large sediment volumes have been deposited in the bay mouth area and northward to the southern end of Tangier Sound (Colman and others, 1992). These data indicate that the greatest sediment volume is associated with the bay mouth. This suggests that, averaged over the Holocene, the continental shelf has been a more significant source of sediment to the bay than the Susquehanna River and other watershed tributaries (Colman and others, 1992).

Although sand is the predominant sediment type in the southern bay, the transport of finegrained sediment northward from the southern regions and from the main stem bay into larger tributaries cannot be dismissed. In a comprehensive survey of the distribution, physical properties, and sedimentation rates in the Virginia part of the bay, Byrne and others (1980) reached the following conclusion:

“... channels leading to the James and York tributaries are mud as are the entrance channels and basis of the embayments of Mobjack, and Pocomoke and Tangier Sounds."

They also concluded that:

"The deposition patterns suggest that there is appreciable advection of fine sand from the baymouth region to at least 35 kilometers up the bay. The area of deposition is argued to occur as a consequence of net up-bay estuarine circulation through the deep channel along the eastern shore."

Byrne and others (1980) also commented on the discrepancy between the sediment budget of Schubel and Carter (1976), based on salt flux calculation, which could not account for the large volume of sediment deposited since the 1840s. Schubel and Carter had proposed that there is net import of sediment from main stem to larger tributaries:

"If indeed the tributaries are sinks for materials transported from the bay, then the apparent discrepancies between bottom accumulation and the previous estimates of source strength are enlarged. If the tributaries are sources rather than sinks, and if the bay mouth is a stronger source than hitherto estimated, then the order of magnitude discrepancy for silt and clay accumulation would be reduced" (emphasis by original authors).

This conclusion suggests that significant amounts of finer-grained material is entering the bay from its mouth and that the sub-estuary rivers are a potential source of fine sediment to the bay (see also Hobbs and others, 1990). Evidence that finer-grained particles derived from the southern bay, possibly from oceanic sources, reach even farther up the bay was discussed in Hobbs and others (1990) who, quoting the work of Halka, concluded that:

$$
\begin{aligned}
& \text { "silts are transported much farther up-estuary } \\
& \text { than had previously been reported." }
\end{aligned}
$$

Other evidence supports the idea that although sand-size material dominates the surface sediments in the southern bay, fine-grained clays and silts also are accumulating in some areas at a rapid rate. In Chapter 2 of this report, the extremely high TSS loads during the winter of 1992 near the mouth of the bay indicated a large potential source for transport northward. Officer and others (1984) reviewed sediment flux rates for the entire bay on the basis of lead-210 dating of sediment cores and determined that sediment mass accumulation rates in the southern bay equaled those of the northern bay where Susquehanna River inflow dominates as a sediment source. Officer and others found that southern bay mass accumulation rates ranged from 0.1 to $0.8 \mathrm{~g} \mathrm{~m}^{-2} \mathrm{yr}^{-1}$. Studies of drift buoys also show that surface currents are capable of carrying finegrained sediments from the bay mouth region far to the north. Harrison and others (1967) showed that bottom drifters released on the shelf have been recovered as far north as Tangier Sound, suggesting that suspended material has the potential for transport relatively far up the bay in the landwardflowing denser saline water.

In summary, sediment in the southern bay is derived mainly from the adjacent ocean with an unknown contribution from shoreline erosion along the bay margins. These sources contribute to relatively high long-term sedimentation rates in the southern main stem bay and in adjacent sounds and embayments. Although much of the sediment deposited in the southern bay is sandsized, part is composed of clay and silt-sized material and there also is good evidence for its significant net up-estuary transport. Because this material has the potential to influence water clarity in the shallow-water bays and sounds of the bay, further study of sediment transport and deposition in the southern bay may be beneficial. 


\section{Internal Sources of Sediment}

This section describes (1) biogenic production of shell material by phytoplankton and benthos in the bay and (2) particulate matter generated internally in the Pocomoke River Basin. Brief mention also is given to the role of SAV in sedimentation.

Biogenic sediments generated within Chesapeake Bay itself can be defined broadly as any material consisting of the remains of organisms generated within the estuary by skeletal formation or organic production. This would include diatom siliceous skeletal material, dinoflagellate cysts, calcareous shells of benthic organisms (mainly foraminifera, ostracodes, mollusks), sponge spicules (siliceous), fish scales and bones (mainly phosphatic), and organic matter from in-situ. Diatoms, for example, can constitute 5-10 percent of dry sediments, and calcareous shells can constitute as much as 5 percent. Biogenic suspended matter of most concern in terms of water quality can be viewed as those components in the water column, mainly phytoplankton (diatoms and dinoflagellates) and zooplankton. Historically, increasing turbidity in the bay, due in part to biogenic suspended matter, has been hypothesized as a contributing factor to the decline in SAV for at least 20 years (Orth and Moore, 1983).

A review of the literature on biogenic components of sediment in Chesapeake Bay can be summarized in two seemingly contradictory conclusions. First, in a comprehensive review of sediment characteristics in the bay and its tributaries that provided quantitative estimates of sediment sources and budgets, Nichols and others (1991) concluded that biogenic production and consumption were "neglected since they are usually small." If one accepts this conclusion, and in light of the lack of biogenic sediment data in most previous studies of Chesapeake Bay sediments, it would at first appear that in-situ generated suspended matter is not quantitatively significant in the overall sediment budget of the bay.

Second, in one of the few studies to consider the composition of suspended sediments in the bay, Biggs (1970) concluded that skeletal material and organic production contributed 18 and 22 percent, respectively, to suspended matter in the mid-bay. In the northern bay, these values were only 2 percent, being overwhelmed by riverine input from the Susquehanna River. Biggs did not consider the southern bay. Extensive literature published since the studies of Nichols and others and Biggs suggests that biogenic material is an important component of suspended matter in the bay and has probably become more important in the past few decades, at least in many areas.

Overall organic productivity (driven by nutrient influx, including silica) has increased substantially during the 20th century. This assertion is based on trends in chlorophyll $a$ (Harding and Perry, 1997), biogenic silica (Cooper and Brush, 1991; Colman and Bratton, oral commun., 2003), diatom floras (Cooper, 1995), dinoflagellates (Willard and others, 2003), carbon and nitrogen isotopes (Bratton and Colman, written commun., 2003), and organic biomarkers (Zimmerman and Canuel, 2000). Much of this increase has taken place since the Biggs study in the 1960s. This suggests the biological component of suspended matter in the bay is in all likelihood progressively increasing, although seasonal and interannual variability is great. Biological processes play an important role in the production, transport, and fate of particulate sediment within and downstream of the Estuarine Turbidity Maximum (ETM) zone (discussed in Chapter 6) of the bay and its large tributaries (Kemp and Boynton, 1984; Fisher and others, 1988) together with tidal resuspension and other processes (Sanford and others, 1991). Organic-inorganic coupling greatly affects particle settling time that, together with physical processes, will determine whether material is deposited in the ETM zone, advected laterally, or transported downstream of the turbidity maximum zone. Ultimately, these processes affect water quality in large parts of the northern bay and under certain conditions the mid-bay. Moreover, biotic processes produce organic carbon, which modulated by regional physical processes (mainly river discharge, sediment grain size), influences the amount of carbon burial in bay sediments (Hobbs, 1983).

Although SAV beds themselves are not a direct source of sediment, they can influence sedimentary processes in coastal ecosystems. Among their potential effects in Chesapeake Bay and its tributaries, SAV can slow water velocity, increase particulate settling rates, improve water clarity, control sediment dynamics, and effect nutrient cycling and water chemistry. Thus, SAV has been referred to as "biological engineers." Because plant biomass varies seasonally, it is likely there is a temporal pattern to SAV-influenced processes and the magnitude of the effect of these processes should vary with SAV abundance and distribution. Little 
research has been carried out on these influences in the Chesapeake Bay. Further research that leads to an understanding of these estuarine and hydrogeomorphological processes would be beneficial.

Ground water of the Pocomoke River Basin is rich in reduced iron, particularly in the Nassawango subbasin where bog iron deposits along the flood plain of Nassawango Creek were stripped in the mid-1800s to supply an iron smelter near the town of Snow Hill. The rate of bog-iron formation was so rapid that areas could be restripped in a matter of a few years. Bog iron is still forming in this area, and in other parts of the Pocomoke Basin. Ferrous iron concentrations in excess of $20 \mathrm{ppm}$ has been measured in ground water. When this water emerges at the surface or is discharged into the river system, it rapidly oxidizes to an amorphous particulate iron oxyhydroxide that in time crystallizes to form the mineral goethite.

The iron in this system is important for at least two reasons. First, iron strongly sorbs phosphorus and many trace metals. Early reports on the composition of the Nassawango bog ore indicate that it commonly contained up to 10 percent phosphorus, which made the pig iron smelted from this ore brittle upon cooling (Singewald, 1911). Second, the iron precipitating in the rivers increases turbidity, which reduces light penetration to rooted aquatic vegetation and effects other organisms by coating gills and interfering with oxygen transfer. The first effect will play a role in the behavior and cycling of phosphorus in the system; the second effect will impact biota in the system.

In the fall of two very dry years (1999 and 2001), a USGS study found the rivers in the central part of the Pocomoke River Basin appeared quite turbid (visual examination) although there had been no storms to wash sediment-laden runoff into the rivers. Samples of the particulate matter creating the turbidity were iron-rich and displayed a weak x-ray diffraction pattern of goethite. Some organic material, probably algae, also seemed to contribute to the turbidity, but this has not yet been investigated. Whatever the mix of materials that caused the turbidity, they were generated internally in the rivers and were not contributed by runoff.

If all the sediment erosion and runoff were eliminated in the Pocomoke River Basin, it would have no effect on the turbidity generated by the iron oxyhydroxide mechanism. Any practice rec- ommended to reduce suspended sediment in these waters must take internally generated "sediment" into consideration. Best-management practices for sediment control in the watershed will probably have little effect on the turbidity generated by internal processes.

In summary, in-situ biological processes are fueled by external nutrient influx, modulated by climate and river discharge variability, and influenced by estuarine circulation, tides, and wind. Well-documented temporal trends of the past century in organic production, phytoplankton ecology, riverine nutrient and sediment influx, although not usually considered in analyses of bay sediment, suggest that biological components of Chesapeake Bay sediment are even more important than they were 40-50 years ago. Although quantitative estimates of the relative contribution of in-situ biogenic material in various regions of the bay cannot be made with certainty on the basis of current data, it is likely that efforts to reduce nutrient influx would improve water clarity by reducing biogenic sediment.

\section{Direct Atmospheric Input}

Direct atmospheric input of particulate matter to the Chesapeake Bay and tributary surface waters is not anticipated to be a major contributor to the total sediment load to the system. The magnitude of sediment particulate input has been estimated from conversations with and information provided by Dr. Joel Baker (University of Maryland Center for Environmental Science, oral commun., 2003). This work stemmed from preliminary sediment-budget calculations performed for Baltimore Harbor and the estuarine part of the Patapsco River, as part of a cooperative program examining contaminants in the harbor bottom sediments (Baker and others, 1997).

Particulate matter in the atmosphere that is deposited on the surface of the bay and its tributaries can be separated into two components: wetfall and dryfall. Suspended particulates in rainwater (wetfall) is estimated to be $1 \mathrm{mg} \mathrm{L}^{-1}$ or $1 \mathrm{~g} \mathrm{~m}^{-3}$. With rainfall averaging about $1 \mathrm{~m} \mathrm{yr}^{-1}$, the direct input of particulates to surface waters is $1 \mathrm{~g} \mathrm{~m}^{-3} \mathrm{yr}^{-1}$. Dryfall is estimated in the following manner. The concentration of particulate matter in the atmosphere is estimated to be $10 \mu \mathrm{g} \mathrm{m}^{-3}$. Assuming an aerodynamic mass median diameter of $1 \mu \mathrm{m}$, these particles settle at a rate of approximately $0.1 \mathrm{~cm} \mathrm{sec}^{-1}$. Multiplying the concentration 
by the settling velocity by the number of seconds per year yields a value for particulate delivery to surface waters of $0.31 \mathrm{~g} \mathrm{~m}^{-3} \mathrm{yr}^{-1}$. Because a part of the atmospheric particulates are soluble, with ammonium sulfate being the dominant aerosol species, the dry deposition flux that contributes to suspended load of surface waters is approximately $0.15 \mathrm{~g} \mathrm{~m}^{-3} \mathrm{yr}^{-1}$. The total particulate load delivered by the atmosphere is estimated to be $1.15 \mathrm{~g} \mathrm{~m}^{-3} \mathrm{yr}^{-1}$.

A data set from an urban location may not be directly applicable to areas of the bay that are bordered by forests, suburban housing, or farmed fields. However, the concentrations utilized probably represent a reasonable median between, for example, forests that deliver little to the atmospheric load and recently tilled fields that on windy days may provide a substantial amount of dryfall to adjacent water bodies. The total atmospheric load is assumed to provide a reasonable approximation of direct sediment input to the bay and its tributaries.
The total surface area of the main stem of the Chesapeake Bay is approximately $6.5 \times 10^{9} \mathrm{~m}$, and the total surface area of the bay plus the tidal tributaries is $11.5 \times 10^{9} \mathrm{~m}$ (Cronin, 1971). Thus, the total flux of atmospheric particulates to the main stem bay is $7.5 \times 10^{9} \mathrm{~g} \mathrm{yr}^{-1}$, and to the bay and the tidal tributaries is $1.3 \times 10^{10} \mathrm{~g} \mathrm{yr}^{-1}\left(8.0 \times 10^{3}\right.$ and $1.4 \times 10^{4}$ metric tons $\mathrm{yr}^{-1}$, respectively). A simple method to characterize the magnitude of these terms is to compare them to the suspended sediment load supplied by the Susquehanna River, which has been well characterized by the USGS as part of the Chesapeake Bay RIM Program. The mean annual sediment load supplied by the Susquehanna River between 1979 and 2001 was $1.2 \times 10^{12} \mathrm{~g} \mathrm{yr}^{-1}$ (Michael Senus, U.S. Geological Survey, oral commun., 2003). Thus, the estimated total wetfall and dryfall associated atmospheric particulate load represents 0.5 percent of the suspended sediment load supplied by the Susquehanna River. 


\section{CHAPTER 6. ESTUARINE SEDIMENT TRANSPORT, DEPOSITION, AND SEDIMENTATION}

\author{
by Thomas Cronin, ${ }^{1}$ Lawrence Sanford, ${ }^{2}$ \\ Michael Langland, ${ }^{1}$ Debra Willard, ${ }^{1}$ \\ and Casey Saenger ${ }^{1}$
}

This chapter discusses the transport, deposition, and sedimentation (accumulation) of sediment in the estuary. Climatic variability and extreme meteorological events exert a strong influence on sediment movement in the estuary over different time scales by affecting river discharge, estuarine circulation, and salinity. Sediment deposition is inherently related to sediment erosion, transport, and re-suspension and involves complex processes operating over different time scales. Although the Chesapeake Bay is one of the most studied estuaries in the world, there are many unknown aspects to sedimentation processes in the bay. The discussion and papers cited provide a valuable source of information about the processes controlling sedimentation. These processes are so interwoven that the discussion of one cannot be separated easily from the others. Therefore, some discussion involves multiple processes and is overlapped intentionally.

\section{Sediment Transport Pathways}

The major pathways of sediment transport in the northern, central, and southern bay and the major tributaries are shown in figure 6.1, which is modified from Hobbs and others (1990). The pathways have been determined from a wide variety of studies of estuarine circulation and stratigraphy, and are based on sedimentation rates from sediment cores, modern and historic sediment composition and distribution of sediment, total suspended solids concentration data, and other sources. This figure also shows information on sediment sources to the bay (Chapter 5). It features the following major characteristics of sediment sources, transport, and deposition:

- a large input of sediment from the ocean near the mouth of the bay,

\footnotetext{
${ }^{1}$ U.S. Geological Survey.

${ }^{2}$ University of Maryland, Center for Environmental Science.
}

- a net southward flow of sediment down the axis of the northern and central main channel (mostly derived from the Susquehanna River),

- an influx of sediment from eroding headlands along the margins of the bay,

- sediment transport from the main stem bay into major tributaries (except during extreme high flow events when sediment can be exported into the bay).

Most researchers agree on these broad patterns that reflect the major physical processes (climate, currents, tides, and density-driven estuarine circulation) and topographic and geomorphic characteristics of the bay region, which govern sedimentation in the estuary (see reviews by Hobbs and others, 1990; Halka, 2000).

Although figure 6.1 indicates major transport pathways, it should be emphasized that finerscale patterns of sediment transport and deposition can vary greatly depending on the region, location, and time scale of the study. Reasons for this variability and the effects of this variability will be discussed in the remaining sections of this chapter. Also note that on figure 6.1, there is no correlation between the size of the arrows and the amount of sediment transported.

\section{Estuarine Turbidity Maxima Zone}

The northern main stem bay and larger tidal tributaries have an Estuarine Turbidity Maxima Zone (ETM zone)-a region where fine-grained particulate material is "trapped," deposited, and sometimes resuspended and redeposited (fig. 6.2). The ETM zone is a result of complex physical processes (freshwater inflow, tidal and wave-driven currents, gravitational circulation), particle flocculation, and biogeochemical processes (Sanford and others, 2001). Within the ETM zone, high rates of fine particle introduction from the watershed together with the physics of estuarine circulation maintain an area of high concentrations of suspended sediment and reduced light availability.

In the Chesapeake Bay, the main ETM zone is north of Baltimore and was the focus of a number of studies in the late 1960s and early 1970s that defined the ETM zone (Schubel, 1968a, 1968b; Schubel and Biggs, 1969; Schubel and Kana, 1972). From these studies, it was determined the main ETM zone of the Chesapeake Bay is associated with the input of sediment and freshwater from 


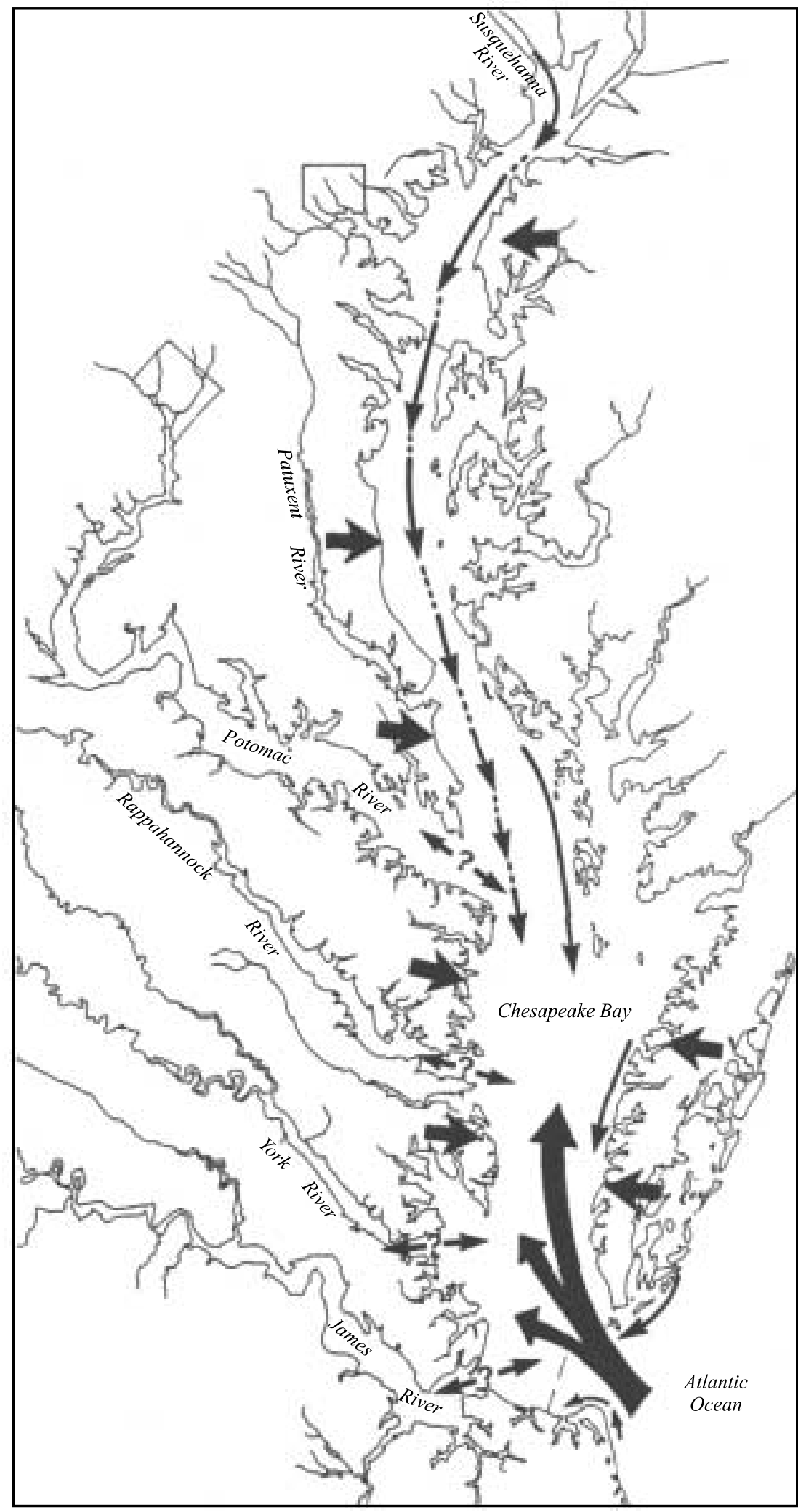

Figure 6.1. Major pathways of sediment transport in Chesapeake Bay (from Hobbs and others, 1990). (Note, the thickness of arrows does not equate to amount of mass transported.) 


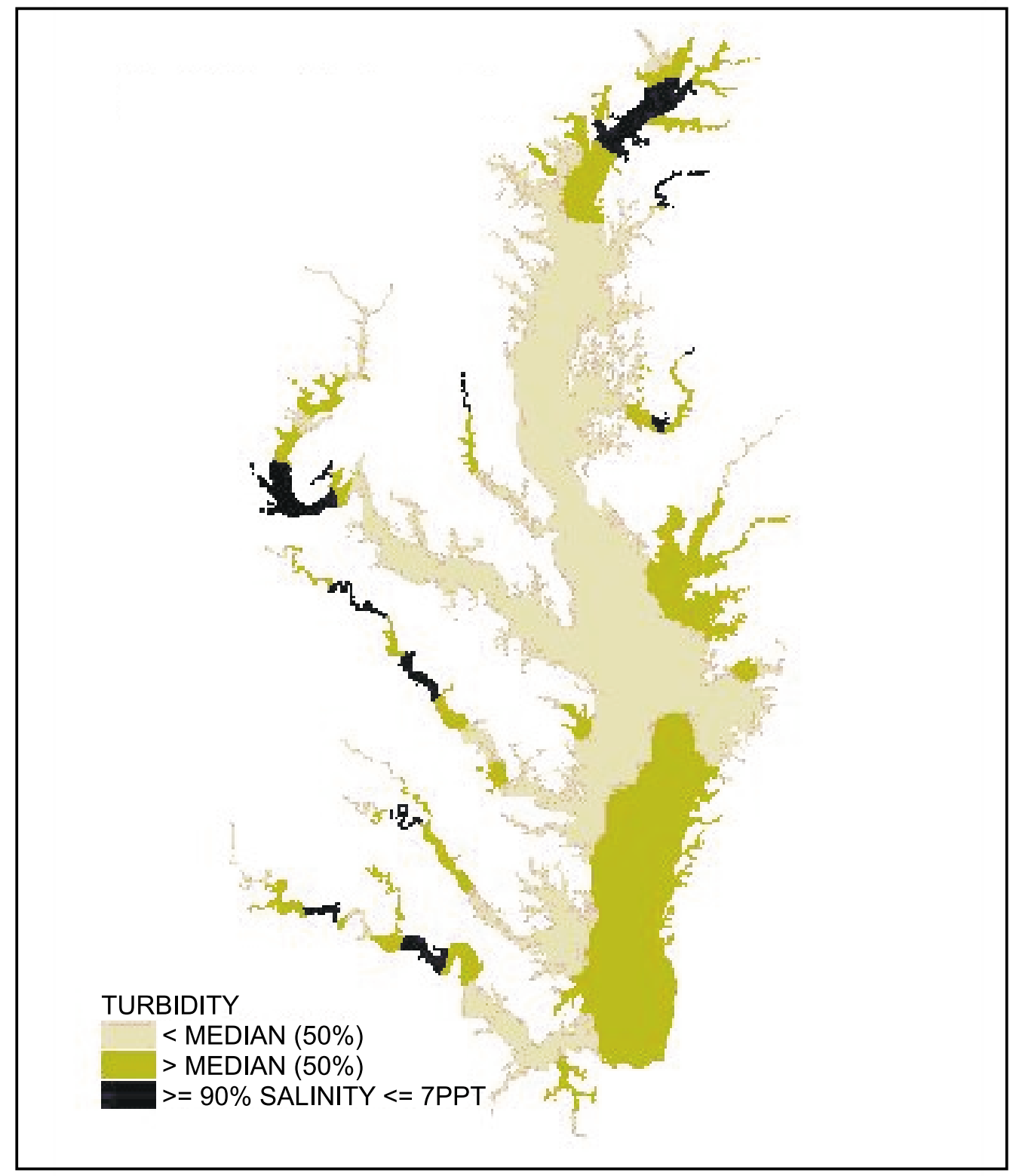

Figure 6.2. General location of turbidity maxima (dark areas) for the major tributaries and the bay (Marsha Olsen, U.S. Environmental Protection Agency, written commun., 2002).

the Susquehanna River. Recent study of the upper Chesapeake Bay ETM zone led Sanford and others (2001) to conclude that asymmetrical tidal resuspension and transport are primarily responsible for the maintenance of the ETM zone at the limit of saltwater intrusion. This is in contrast to the earlier Chesapeake studies that ascribed the formation of the ETM zone primarily to gravitational circulation patterns but is quite similar to recent studies of ETM zones in other locations. However, all the studies have confirmed the importance of resuspension processes to the maintenance of high concentrations of suspended sediment and associated light attenuation. Without the effects of tidal resuspension, the rapidly settling aggregates of fine particles would remain on the bottom.

Each of the tributary systems have an associated ETM zone near the upstream limit of saltwater intrusion. Examples have been noted in the Rappahannock (Nichols, 1977), the Potomac (Knebel and others, 1981), and the York (Lin and Kuo, 2001) Rivers. Analysis of Chesapeake Bay water-quality monitoring data sets for the Patuxent and Choptank Rivers indicate the appearance of similar turbidity maxima zones in these smaller 
sub-estuaries (Larry Sanford, unpub. data, 2003). Some tributaries have more than one ETM zone (Lin and Kuo, 2001), probably because of multiple convergent transport zones. An additional complexity, which is not well understood, is the potential for seasonally varying sediment trapping in the ETM zone (Sanford and others, 2001).

Extreme events like flooding and drought involving the mobilization and transport of sediment in the watershed influence the movement of the ETM zone up and down in the tidal estuaries and the main stem of the bay. The ETM zone typically is near the freshwater/saltwater interface where a large percentage of riverine sediment is trapped. Major storms and increased river discharge deliver higher sediment loads to the estuary and can shift the location of the ETM zone several tens of kilometers downstream, allowing sediment to "escape" the usual ETM zone. However, the majority of fine-grained river-borne sediment is trapped in ETM zones and only escapes the upper reaches of the northern Bay and upper parts of tributaries during extreme hydrologic events. These limited results must be regarded as tentative, however, because most studies have focused on relatively short time scales (days to weeks, with a few interannual comparisons).

\section{Influence of Climate}

Climatic variability and extreme meteorological events strongly influence sediment and nutrient transport to the Chesapeake Bay and its tributaries. During periods of high precipitation and above-mean river discharge, climate-driven processes can lead to scouring of sediments from behind dams, increases in suspended solids in the water column, shifts in the position of ETM zones, export of sediment from ETM zones, increased mean turbidity, and other changes in sedimentary processes. Conversely, during periods of drought such as that seen during late 2001-early 2002, relatively low freshwater flows can contribute to high water clarity and relatively robust growth in SAV beds. This section briefly describes climate processes operating over long term (millennial), intermediate (centennial, decadal, interannual), and short-term (extreme events, seasonal) time scales derived from a selective review of the literature. A more detailed review of the general subject of climate-driven changes in freshwater flow to estuaries and its physical, chemical, and biological effects was provided by Albers and others (written commun., 2003).

\section{Long-Term Processes}

Geophysical surveys and stratigraphic and radiocarbon studies of long sediment cores have documented the long-term history of Chesapeake Bay. These studies show that the bay formed during the early Holocene period, about 8,000 years before present (yr BP), when a rising sea level flooded the ancient Susquehanna River Valley (Colman and others, 1988; Cronin and others, 2000). Relative sea level has continued to rise because of subsidence of the mid-Atlantic region due to post-glacial isostatic adjustment (Ellison and Nichols, 1976; Peltier, 1996; Kearney, 1996; Colman and others, 2001; Bratton and others, 2002, Cronin and others, 2003).

Since its inception, the bay has been the site of sediment accumulation, which reaches a total thickness of 25-30 $\mathrm{m}$ in some parts of the main channel of the bay. On the flanks of the bay, Holocene sedimentary sequences consist mainly of sandy sediments and are relatively thin because of the winnowing action of waves, currents, and tides that tend to transport fine-grained sediment from the flanks to the deeper channel.

Long sediment cores have penetrated through the entire Holocene sequence into fluvial sediments. Coupled with geophysical surveys, these records indicate that complex long-term sedimentation patterns characterize parts of the bay. For example, some regions have experienced several thousand years of relatively continuous deposition, followed by no net sediment deposition for several thousand years. These stratigraphic unconformities represent either periods of non-deposition or deposition followed by substantial periods of submarine erosion. It is difficult to explain this intermittent Holocene sedimentation over millennial time scales. Most likely, climatological factors may influence erosion and sediment transport from rivers and geologic processes, such as lithologic composition of pre-Holocene sediments, preHolocene topography inherited from late-Pleistocene low sea level, and submarine gravity sliding and tidal currents, govern long-term sedimentation patterns and rates. Unconformities have been recognized in sediments deposited in various areas during the early $(8,000-10,000 \mathrm{yr} \mathrm{BP})$, middle ( 3,000-6,000 yr BP), and late Holocene $(3,000 \mathrm{yr}$ $\mathrm{BP}$ to present). Even in cores containing a fairly continuous record of deep channel sedimentation over several millennia, significant lithologic changes in the sediment composition are common. 
These most likely signify changes in sediment source, currents, tides, and circulation, or other factors.

Rising sea level during the past 8,000 years (see also Sediment Rates section below) also has had an effect on sediment sources and transport to Chesapeake Bay because of its influence on cliff and coastal marsh erosion. In general, rising sea level leads to submergence of land areas and has the potential to increase the proportion of sediment derived from coastal erosion relative to sediment from riverine, oceanic, and biogenic sources. Over the past century, the rate of relative sea-level rise in the Chesapeake Bay region has been about twice the global rate because of regional land submergence caused by post-glacial isostatic adjustment. Estimates of future rates of global sea-level rise from natural and anthropogenic causes (such as global warming) are subject to large uncertainty. However, despite this uncertainty, the bay area will continue to experience submergence and largescale coastal erosion over the next century because of continuing regional subsidence. This means that, without management of coastal zones, a large, perhaps increasing, contribution of future sediment will come from shoreline sources.

\section{Centennial, Decadal, and Interannual Time Scales}

Climate processes operating over centennial, decadal, and interannual time scales are the subject of intensive research programs aimed at distinguishing natural climate variability and its causes from human-induced 20th century climate change ("global warming"). The causes of regional climate variability are still poorly understood. Several studies of the sedimentary record in the bay have demonstrated that the mid-Atlantic region in general, and Chesapeake Bay in particular, have experienced quasi-cyclic oscillations in precipitation and temperature over the past few millennia.

Stratigraphic and paleoecological evidence from changes in salinity-sensitive foraminifera indicate salinity oscillations of $10-15 \mathrm{ppt}$ in the mesohaline region at $11-\mathrm{m}$ water depth during the past 500 years (Cronin and others, 2000). Fourteen "wet-dry" cycles, including 16th and 17th century "mega-droughts" could be recognized that exceeded 20th century droughts in their severity. Wet periods occurred nearly every 60-70 years, lasting less than 20 years; the mean annual rainfall was 25-30 percent above normal, and freshwater discharge was about 50 percent greater than dur- ing droughts. Climatological processes (increased precipitation and river discharge) also are partially responsible for broad ecosystem degradation and greater hypoxia since the 1960s. This also may reflect the combined effects of lower dissolved oxygen (DO) and decreased water clarity (Karlsen and others, 2000). Although the direct effect of these well-documented climatological processes on sedimentation are uncertain, the paleoecological patterns suggest a multi-decadal pattern of improved water clarity during relatively dry intervals, and decreased clarity during extended wet periods. These climate-driven estuarine changes are superimposed on long-term ecosystem response to land clearance and nutrient influx (Brush, 1984; Cooper and Brush, 1991; Willard and others, 2003).

Decadal to centennial oscillations in Chesapeake Bay temperatures have been discovered on the basis of the trace element chemistry in fossil ostracode shells from well-dated sediment cores (Cronin and others, 2003). These studies indicated changes in mean spring-summer water temperatures of several degrees Celsius during the Medieval Warm Period (800-1400 AD) and Little Ice Age (1400-1900 AD) and that 20th-century temperature extremes exceeded those of the past 2,200 years. Although not directly related to sedimentary processes, these results suggest the mid-Atlantic region is sensitive to natural and anthropogenic climate variability over time scales pertinent to long-term water-quality management.

Interannual and decadal quasi-cyclic oscillations of sedimentation are recorded in physical, chemical, and biological records in many sediment cores. For example, physical and chemical sedimentary changes are evident in oscillations of sediment color measured using Kodak Grey Scale imagery (KGS). Alternating light and dark sedimentary layers reflect changes in sediment geochemistry and grain size related to hypoxia and methane production (Hill and others, 1992). These changes have been identified in a number of long sediment cores in the main stem of the bay (T. Cronin, U.S. Geological Survey, written commun., 2003). At a site off the mouth of the Little Choptank River, a nearly completed integrated study conducted by the USGS and Maryland Geological Survey has documented episodic (cycles of $\sim 2-4$ and 10-15 years) changes in sediment source using KGS, cesium-137, and micropaleontology (T. Cronin and J. Hill, oral commun, 2003). The data imply that over the past century, year-to-year changes in sediment source are a characteristic of 
at least this region of the bay. During wet years, greater proportions of land surface and coastal marsh sediments are deposited; during relatively dry years, sediment from riverine input and (or) re-suspension dominates.

There is a large body of literature using the bay's paleoecological and geochemical record recovered from sediment cores to document changes in the bay ecosystem caused by post-colonization land clearance, and more recently, fertilizer application and elevated nutrient influx (see Cooper and Brush, 1991; Karlsen and others, 2000, Colman and Bratton, 2003; Cronin and Vann, 2003). Most of these studies have focused on issues related to DO levels in the bay. Although the effect of land-use activities on DO is severe and well documented, the effect of climate variability is also of great significance for sediment flux and temperature variability. This is because even the most ambitious restoration efforts will not return the watershed to pre-colonization conditions. Additional investigations of the influence of climate variability on sediment flux into and within the bay would lead to further understanding of this issue.

\section{Short-Term Extreme Events}

Extreme meteorological events such as storms and hurricanes can lead to flooding, periods of extremely high TSS loading, and massive sediment transport. Flooding mobilizes, transports, and delivers large amounts of sediments in a relatively short time, potentially resulting in both immediate and lasting environmental damage. Perhaps the most well-studied extreme event was Hurricane Agnes in June 1972 that has been credited with initiating a decline in the SAV populations of the bay that, according to some researchers, have yet to recover in certain regions (Davis and Laird, 1976; Orth and Moore, 1983). The Agnes-induced floods of June 1972 in the Susquehanna River Basin had nearly the same peak discharge as floods caused by events in January 1996-about 1 million $\mathrm{ft}^{3} \mathrm{~s}^{-1}\left(410\right.$ million gal $\left.\mathrm{min}^{-1}\right)$ (Langland and Hainly, 1997). The total streamflow discharge was approximately double for the June 1972 flood compared to the January 1996 flood; the sediment load during the 1972 flood was triple the 1996 sediment load (30 million tons compared to 10 million tons, respectively). More sediment was available and transported to the upper bay because of increased land disturbance in summer (1972) compared to winter (1996).
Monitoring records of suspended sediment are useful indicators of extreme events in relation to more typical "average hydrological" conditions. From 1979 to 2001, the average annual sediment load delivered to the Chesapeake Bay from the major sub-basins at the Fall Line was estimated to be approximately 4 million tons. (During the period 1979 to 1984, the loads represented the combined input from the three largest rivers (Susquehanna, Potomac, and James). During this time period, the average annual sediment load transported was more than doubled (10 million tons) on four occasions, 1979, 1984, 1985, and 1996, totaling approximately 60 millions tons of sediment. In 1972 , an estimated 30 million tons of sediment was delivered to the upper bay. These extreme events all were related directly to tropical storms that delivered unusually large amounts of rainfall over large land areas. An exception was 1996, when heavy rains, deep snow pack, and above normal winter temperatures combined to create an unusual sequence of events resulting in high flows and scouring of reservoir sediments in the lower Susquehanna River. The scoured sediments were the dominant source of the transported sediment (Langland and Hainly, 1997). Conversely, the annual sediment load was nearly half ( 2.5 million tons) the long-term average on eight occasions: 1981, 1991-92, 1995, 1997, 1999-2001. The majority of the watershed had a precipitation deficit since 1999. The average annual sediment load for 1999-2001 was less than 1 million tons, one-fifth of the annual long-term sediment load.

The greatest effects of extreme events like flooding and drought involve the mobilization and transport of sediment in the watershed and the movement of the ETM zone up and down in the tidal estuaries and in the main stem of the bay (fig. 6.2). The ETM zone typically is near the freshwater/saltwater interface where a large percentage of riverine sediment is trapped. Major storms and increased river discharge deliver higher sediment loads to the estuary and can shift the location of the ETM zone several tens of kilometers downstream, allowing sediment to "escape" the ETM zone. Some tributaries have more than one ETM zone. The most upstream ETM zone probably reflects the riverine source; the downstream ETM zone would be dominated by shoreline erosion, resuspension, and fine-sediment input from the bay. An additional complexity, however, is a seasonality to storm-induced sedimentary trapping in the ETM zone (Sanford and others, 2001). 
In summary, episodic events, interannual and decadal variability, and long-term changes in mean climatic conditions are all characteristics of natural processes affecting the bay system. In light of evidence that humans have altered the global climate system, producing anomalous climate behavior in many regions, it is important to obtain a better understanding of the regional climate behavior and its effect on the bay. Although statistics on trends in streamflow and precipitation can indicate the probability of an extreme, short-term event taking place during a given time span, the actual prediction of a time and place is very imprecise at best, if not impossible. However, improved predictability of interannual climate variability associated with El Nino-Southern Oscillation now is applied routinely when trying to solve agricultural and environmental problems. Recent advances have been made in regional climate models for the mid-Atlantic (Crane and Hewiston, 1998; Jenkins and Barron, 1996; Najjar, 1999), and these have been applied to predictions of future salinity change in the bay (Gibson and Najjar, 2000). Similar efforts are needed to understand future changes in sediment flux that will result from more frequent extreme climate events and greater interannual variability. Coupled with better understanding of the patterns and causes of past climate and sediment variability, predicting future changes in regional mid-Atlantic climate using regional climate models could be an important component of future research, planning, and management.

\section{Deposition and Sedimentation Rates}

Most researchers define sedimentation rate as the linear accumulation of sediment in centimeters per year and convert this rate into volumetric estimates of sediment flux, or mass accumulation rate (MAR), usually given in grams per square meter per year or grams per cubic centimeter per year. These conventions are followed here and in tables 6.1 and 6.2, and form the basis of discussion for the remainder of this chapter. Table 6.1 provides an abstracted summary of each publication's region of investigation, methodology, and estimated sedimentation rates. Table 6.2 is a selective summary of published studies covering many regions in the bay area. Because of widely varying field and analytical methods, statistical techniques, and the temporal and spatial variability in sedimentation, it is recommended strongly that the reader examine the original papers of interest for details.
A variety of approaches have been used to study patterns and processes of bay sedimentation (table 6.1). These include the following methods: geophysical surveys (determining rates of the past 7,500 years of estuarine sedimentation), bathymetric surveys (comparing 19th and 20th century bathymetry), short-lived radioisotopes $\left({ }^{137} \mathrm{Cs}\right.$, ${ }^{210} \mathrm{~Pb}$ ), other chemical markers (useful for the past century), and pollen stratigraphy (mainly Ambrosia, ragweed, pollen) correlated with land-use changes (documenting post-colonization landclearance rates). Monitoring methods not included in tables 6.1 or 6.2 include instrumental measurement of total suspended solids in water samples and satellite imagery and remote sensing.

Radiocarbon $\left({ }^{14} \mathrm{C}\right)$ dating has been used to estimate sedimentation rates in Chesapeake Bay. However, measured radiocarbon ages are a function of complex processes including cosmogenic radiocarbon production in the atmosphere, carbon cycling in the hydrosphere and biosphere, and the potential uptake of reservoir ("old") carbon into different types of carbonaceous material (such as wood, peat, total organic carbon, shells). Radiocarbon ages that have not been calibrated to the global carbon cycle can provide inaccurate ages and, in the case of many ages published for Chesapeake Bay, can lead to erroneous estimates of sedimentation rates.

Three broad, well-supported conclusions can be drawn from the data in tables 6.1 and 6.2. First, sedimentation rates are relatively high-on the order of 0.1 to $1 \mathrm{~cm} \mathrm{yr}^{-1}$ - compared to those characteristic of other aquatic environments such as most lakes, deep sea habitats, bays, and estuaries. Because the bay was flooded by sea-level rise about $8,000-7,500$ years ago, as much as $25-30 \mathrm{~m}$ of sediment have accumulated in the main channel, and thick accumulations of sediment characterize the marshes of the bay. High sedimentation rates in the channel reflect in part the sediment-trapping capability of partially mixed estuaries. This is the result of several factors, some of which are discussed below.

Second, sedimentation rates vary widely depending on the region. For example, sedimentation rates can easily vary five- to ten-fold ( 0.1 to greater than $1.0 \mathrm{~cm} \mathrm{yr}^{-1}$ ) over small and large spatial scales. Spatial variability is evident especially throughout the main stem of the mid-bay and locally in small sub-estuaries such as the Rhode River and tributaries entering the Potomac. 
Table 6.1. Summary of sedimentation rates in Chesapeake Bay and tributaries from selected published studies

[m, meter; cm, centimeter; g, gram; yr, year; NA, not applicable; <, less than; >, greater than; Pb, lead; C, carbon; Pu, plutonium; Cu, copper; Cs, cesium; TSS, total suspended solids; --, no data]

\begin{tabular}{|c|c|c|c|c|c|c|c|c|}
\hline Core & Reference & Location & $\begin{array}{l}\text { Water } \\
\text { depth } \\
(\mathrm{m})\end{array}$ & $\begin{array}{c}\text { Mean annual } \\
\text { linear sediment } \\
\text { rate } \\
(\mathrm{cm} / \mathrm{yr})^{1}\end{array}$ & $\begin{array}{l}\text { Mean annual } \\
\text { sediment flux } \\
\left(\mathrm{g} / \mathrm{cm}^{-2} / \mathrm{yr}\right)^{1}\end{array}$ & $\begin{array}{l}\text { Time } \\
\text { interval }\end{array}$ & Method & Comments \\
\hline PC-6 & $\begin{array}{l}\text { Adelson and others (2001); Helz and } \\
\text { others (2000) }\end{array}$ & $\begin{array}{l}\text { Main stem of } \\
\text { Calvert Cliffs }\end{array}$ & 20 & $\begin{array}{c}3.1-4.2 \\
0.11\end{array}$ & $\begin{array}{c}1.2-1.36 \\
0.07\end{array}$ & $\begin{array}{l}\text { Post-colonial } \\
\text { Pre-colonial }\end{array}$ & $\begin{array}{l}{ }^{14} \mathrm{C}\left({ }^{210} \mathrm{~Pb}, \mathrm{Pu},\right. \\
\text { Cu peak) }\end{array}$ & Discontinuity in Sedimentation \\
\hline \multirow[t]{20}{*}{$\begin{array}{r}\text { Gmss 16, } \\
\text { Gmssc }\end{array}$} & Adelson and others (2001) & $\begin{array}{l}\text { Main stem off } \\
\text { Patuxent }\end{array}$ & NA & 2.84 & 1.07 & Post-colonial & ${ }^{210} \mathrm{~Pb}$ & \\
\hline & Cornwell and others (1996) & $\begin{array}{l}\text { Mid-bay } \\
\text { main stem }\end{array}$ & $\begin{array}{l}17.5 \\
15\end{array}$ & $\begin{array}{l}-- \\
--\end{array}$ & $\begin{array}{l}2.4 \\
1.8\end{array}$ & Post-colonial & ${ }^{210} \mathrm{~Pb}$ & \\
\hline & Roberts and Pierce (1976) & Patuxent & NA & 3.70 & $5.5-7.45$ & 1970s & TSS & \\
\hline & $\begin{array}{l}\text { Hobbs and others (1992); Kerhin and } \\
\text { others (1988) }\end{array}$ & Baywide & Various & 0.64 & NA & $1840 s-1950 s$ & Bathymetic survey & \\
\hline & $\begin{array}{l}\text { Officer and others (1984) } \\
\text { (Summarizes Hirschberg and } \\
\text { Schubel, 1979; Helz and others, } \\
\text { 2000; and Goldberg and others, } \\
\text { 1978) }\end{array}$ & $\begin{array}{l}\text { North bay } \\
\text { Mid bay } \\
\text { South bay }\end{array}$ & $\begin{array}{l}4-32 \\
8-33 \\
4-13\end{array}$ & $\begin{array}{l}-- \\
-- \\
--\end{array}$ & $\begin{array}{l}0.3-1.2 \\
0.1-0.3 \\
0.1-0.8\end{array}$ & $\begin{array}{l}\text { 20th century } \\
\text { 20th century } \\
\text { 20th century }\end{array}$ & $\begin{array}{l}{ }^{210} \mathrm{~Pb},{ }^{137} \mathrm{Cs} \\
{ }^{239} / 240 \mathrm{Pu}\end{array}$ & Episodic sedimentation noted. \\
\hline & Donoghue (1990) & Rhode River & NA & $\begin{array}{c}0.07-0.47 \\
0.5-1.5\end{array}$ & NA & $\begin{array}{l}\text { Pre-colonial } \\
\text { Post-colonial }\end{array}$ & ${ }^{14} \mathrm{C},{ }^{210} \mathrm{~Pb},{ }^{137} \mathrm{Cs}$ & $\begin{array}{l}\text { See Donoghue (1990) for variations in Rhode River } \\
\text { and summary of other studies. }\end{array}$ \\
\hline & $\begin{array}{l}\text { Defries (1986); Brush and others } \\
\quad(1982) ; \text { Knebel and others (1981) }\end{array}$ & $\begin{array}{l}\text { Potomac East } \\
\text { Potomac East }\end{array}$ & $0.3-12.8$ & $\begin{array}{l}>0.1->0.47 \\
0.21->1.14\end{array}$ & $\begin{array}{c}2>0.05-0.19 \\
0.09->1.0\end{array}$ & $\begin{array}{l}\text { Post-colonial } \\
\text { Post-colonial }\end{array}$ & Pollen, ${ }^{210} \mathrm{~Pb},{ }^{137} \mathrm{Cs}$ & $\begin{array}{l}\text { Lower rates near mouth, highest upper est. and } \\
\text { tributaries, pre-colonial rates given. }\end{array}$ \\
\hline & Brush $(1984,1989)$ & $\begin{array}{l}\text { Furnace bay } \\
\text { Magothy } \\
\text { Nanticoke }\end{array}$ & $\begin{array}{l}\sim 1 \\
-- \\
--\end{array}$ & $\begin{array}{c}0.17-0.39 \\
0.04-0.23 \\
0.2\end{array}$ & $0.15-0.20$ & $\begin{array}{l}\text { Post-colonial } \\
\text { Post-colonial } \\
\text { Post-colonial }\end{array}$ & $\begin{array}{l}\text { Pollen } \\
\text { Pollen } \\
\text { Pollen }\end{array}$ & $\begin{array}{l}\text { X broke down upper-mid-lower est. All post-land } \\
\text { clearance European rates. Rates in paper vary by } \\
\text { time, period, region, core. }\end{array}$ \\
\hline & Brush (1984) & Patuxent & $\sim 5$ & 0.51 & & Post-colonial & & \\
\hline & Brush (1984) & 10 Tributaries & Various & ${ }^{2} 0.17-0.35$ & $0.14-0.18$ & Post-colonial & & Mean post-European rates, vary location, tributary. \\
\hline & Cooper and Brush $(1991,1993)$ & Mid bay & $9-15.1$ & $0.17-0.31$ & & Post-colonial & $\begin{array}{l}{ }^{210} \mathrm{~Pb},{ }^{137} \mathrm{Cs}, \\
{ }^{14} \mathrm{C} \text {, Pollen }\end{array}$ & Some pre-colonial dates given. \\
\hline & Khan and Brush (1994) & Jue bay & $\begin{array}{l}\text { High marsh } \\
\text { intertidal }\end{array}$ & $0.15-0.89$ & $\sim 0.09-0.52$ & Post-colonial & Pollen & \\
\hline & Khan and Brush (1994) & Patuxent & Low marsh & $0.18-0.7$ & $0.09-0.56$ & Post-colonial & Pollen & \\
\hline & Brush and Davis (1984) & Ware River & $2.5-7.0$ & $0.36-0.39$ & & Post-colonial & & \\
\hline & Brush and Hilgartner (2000) & $\begin{array}{l}36 \text { cores, } \\
8 \text { tributaries }\end{array}$ & $<1-2.2$ & $0.02-3.0$ & & Post-colonial & Pollen, ${ }^{14} \mathrm{C}$ & $\begin{array}{l}\text { Sedimentation rates vary temporally and spatially. } \\
\text { Approx. range given. }\end{array}$ \\
\hline & Pasternak and Brush (2001) & Bush River & Various & NA & 1 & Recent & Monitoring & \\
\hline & Halka (2000) & Entire bay & Various & ${ }^{3}<0.1-0.5$ & $\sim 0.04-0.2$ & Holocene & Geophysical survey & \\
\hline & Zimmerman and Canuel (2000) & Mid-bay & 15 & $1.0-1.67$ & 0.477 & Post-colonial & $\begin{array}{l}{ }^{210} \mathrm{~Pb},{ }^{137} \mathrm{Cs} \\
\text { Pollen }\end{array}$ & Sedimentation rate varies. \\
\hline & Cutshall and others (1981) & James River & NA & $1.0-19.0$ & NA & 20th century & ${ }^{137} \mathrm{Cs}$ & \\
\hline & Donoghue and others (1989) & North bay & NA & 0.35 & 0.27 & Post-colonial & ${ }^{137} \mathrm{Cs}$ & \\
\hline
\end{tabular}

NOTE: See individual papers for methods, error bars. Values were rounded when multiple papers gave slightly different values.

${ }^{1}$ When range is not given, values are means.

2 1600-1700s.

${ }^{3}$ Mean $\sim 0.15$ 
Table 6.2. Summary of chronological and sedimentary rate data for Chesapeake Bay

[m, meters; cm, centimeters; $\mathrm{g} / \mathrm{cm}^{2}$, grams per square centimeters; RW, Ragweed; --, no data; Cs, cesium; C, carbon]

\begin{tabular}{|c|c|c|c|c|c|c|c|c|c|c|c|c|c|c|c|c|c|}
\hline Region & Core & $\begin{array}{l}\text { Water } \\
\text { depth } \\
\text { (m) }\end{array}$ & $\begin{array}{l}\text { Latitude } \\
\text { (degrees) }\end{array}$ & $\begin{array}{l}\text { Longitude } \\
\text { (degrees) }\end{array}$ & $\begin{array}{l}\text { Date } \\
\text { cored }\end{array}$ & $\begin{array}{l}\text { Coring } \\
\text { method }\end{array}$ & $\begin{array}{l}\text { Core } \\
\text { length } \\
(\mathrm{cm})\end{array}$ & $\begin{array}{l}\text { Depth } \\
\text { to } \\
{ }^{137} \mathrm{Cs} \\
\text { peak } \\
(\mathrm{cm})^{1}\end{array}$ & $\begin{array}{l}\text { Depth } \\
\text { to } \\
\text { rag- } \\
\text { weed } \\
\text { peak } \\
(\mathrm{cm})^{2}\end{array}$ & $\begin{array}{l}\text { Depth } \\
\text { range } \\
\text { of } \\
\text { rag- } \\
\text { weed } \\
\text { peak } \\
(\mathrm{cm})\end{array}$ & $\begin{array}{l}\text { Depth } \\
\text { to } \\
{ }^{14} \mathrm{C} \\
950 \\
\text { yr } \\
\text { date } \\
(\mathrm{cm})\end{array}$ & $\begin{array}{c}\text { Age } \\
{ }^{14} \mathrm{C} \\
\text { date } \\
(\mathrm{yr} \mathrm{BP})^{3}\end{array}$ & $\begin{array}{c}\text { Mean } \\
\text { annual } \\
\text { lin. } \\
\text { sed. rate } \\
\text { post- } \\
\text { RW } \\
\text { (cm/yr) }\end{array}$ & $\begin{array}{l}\text { Mean } \\
\text { annual } \\
\text { lin. sed } \\
\text { rate } \\
\text { pre-RW } \\
(\mathrm{cm} / \mathrm{yr})\end{array}$ & $\begin{array}{l}\text { Post-RW } \\
\text { sed. flux } \\
\left(\mathrm{g} / \mathrm{cm}^{2} \mathrm{yr}^{-1}\right)\end{array}$ & $\begin{array}{l}\text { Pre-RW } \\
\text { sed. flux } \\
\left(\mathrm{g} / \mathrm{cm}^{2} \mathrm{yr}^{-1}\right)\end{array}$ & Comments/sources \\
\hline $\begin{array}{r}\text { IMAGES } \\
\text { Cruise }\end{array}$ & MD99-2205 & 16.0 & $3833.95 \mathrm{~N}$ & $7626.66 \mathrm{~W}$ & June 21, 1999 & Calypso & 673 & -- & 130 & -- & 300 & 466 & 1.0833 & 0.4293 & 0.3683 & 0.2318 & $\begin{array}{l}\text { Unconformity at } \\
300 \mathrm{~cm} / \text { Cronin } \\
\text { and others (2000) }\end{array}$ \\
\hline $\begin{array}{l}\text { IMAGES } \\
\text { Cruise }\end{array}$ & MD99-2207 & 25.0 & $3801.83 \mathrm{~N}$ & $7612.88 \mathrm{~W}$ & June 21,1999 & Calypso & 2,070 & -- & 139 & 20 & 173 & 950 & 1.1583 & .0386 & .3938 & .0209 & $\begin{array}{l}\text { Cronin and others } \\
(2000)\end{array}$ \\
\hline $\begin{array}{r}\text { IMAGES } \\
\text { Cruise }\end{array}$ & MD99-2209 & 26.0 & $3853.18 \mathrm{~N}$ & $7623.68 \mathrm{~W}$ & June 22, 1999 & Calypso & 1,720 & 94 & 221 & 20 & 510 & 950 & 1.8417 & .3284 & 6262 & . 1773 & $\begin{array}{l}\text { NAO paper age } \\
\text { model / } \\
\text { Cronin and others, } \\
(2000)\end{array}$ \\
\hline $\begin{array}{l}\text { Patuxent } \\
\text { Transect }\end{array}$ & PTXT-2-G & 11.5 & $3819.58 \mathrm{~N}$ & $7623.54 \mathrm{~W}$ & Sept. 18, 1996 & Gravity & 116 & 36 & 68.5 & 8.5 & -- & -- & .5708 & -- & 1941 & -- & $\begin{array}{l}\text { Gravity core depth } \\
1.2^{1}\end{array}$ \\
\hline \multirow[t]{2}{*}{ Main stem } & AZM3 & 15.0 & $3834.05 \mathrm{~N}$ & $7626.76 \mathrm{~W}$ & March 1, 1996 & Kasten & 242 & 51 & 111 & 20 & -- & -- & .9250 & -- & .3145 & -- & $\begin{array}{l}\text { Cs peak from } \\
\text { A. Zimmerman }\end{array}$ \\
\hline & $\begin{array}{l}\text { Bachelors } \\
\text { Point } \\
\text { Core } 695\end{array}$ & & $3840.03 \mathrm{~N}$ & $7610.648 \mathrm{~W}$ & & Piston & 300 & -- & 30 & 10 & -- & -- & .2500 & -- & .0850 & -- & $\begin{array}{l}\text { From G. Smith, Md. } \\
\text { DNR }\end{array}$ \\
\hline Mid-Bay & $\begin{array}{l}\text { CB MB-2 } \\
\text { (Parker) }\end{array}$ & 25.1 & $3833.079 \mathrm{~N}$ & $7626.0297 \mathrm{~W}$ & June 6, 2001 & Piston & 494 & -- & 120 & 40 & -- & -- & 1.0000 & -- & .3400 & -- & $\begin{array}{l}\text { From A. Mannino, } \\
\text { USGS }\end{array}$ \\
\hline Mid-Bay & CB-2207 & 26.1 & $3812.822 \mathrm{~N}$ & $7612.876 \mathrm{~W}$ & June 6, 2001 & Piston & 476 & -- & 145 & 15 & -- & -- & 1.2083 & -- & .4108 & -- & $\begin{array}{l}\text { From A. Mannino, } \\
\text { USGS }\end{array}$ \\
\hline Potomac River & DEFRIES-5-1 & 5.8 & $3816.735 \mathrm{~N}$ & 76 49.722W & $\begin{array}{l}\text { Sept. 19-20, } \\
2001\end{array}$ & Piston & 210 & -- & 9 & -- & 139 & 950 & .0750 & .1477 & .0255 & .0798 & New data \\
\hline $\begin{array}{l}\text { Little } \\
\text { Choptank }\end{array}$ & $\begin{array}{l}\text { LCHPT-1- } \\
\text { P-4\&5 }\end{array}$ & 14.9 & $3831.493 \mathrm{~N}$ & $7618.212 W$ & & Piston & 400 & 150 & 271 & 30 & -- & -- & 2.2583 & -- & .7678 & -- & New data \\
\hline Potomac River & NKL-12-1 & 6.9 & $3810.101 \mathrm{~N}$ & 76 43.168W & $\begin{array}{l}\text { Sept. 19-20, } \\
2001\end{array}$ & Piston & 200 & -- & 31 & -- & 107 & 950 & .2583 & .0864 & .0878 & .0466 & New data \\
\hline Potomac River & NKL-16-1 & 7.4 & $3806.334 \mathrm{~N}$ & 76 34.193W & $\begin{array}{l}\text { Sept. 19-20, } \\
2001\end{array}$ & Piston & 154 & -- & 9 & -- & 86 & 950 & .0750 & .0875 & .0255 & .0473 & New data \\
\hline Potomac River & NOMBAY-1 & 5.2 & $3808.898 \mathrm{~N}$ & 76 43.173W & $\begin{array}{l}\text { Sept. 19-20, } \\
2001\end{array}$ & Piston & 200 & -- & 61 & -- & 98 & 950 & .5083 & .0420 & . 1728 & .0227 & New data \\
\hline $\begin{array}{l}\text { Pocomoke } \\
\text { Sound }\end{array}$ & PC2B-1\&2 & 7.9 & $3753.433 \mathrm{~N}$ & 75 48.409W & Sept. 18, 2001 & Piston & 480 & -- & 240 & 20 & -- & -- & 2.0000 & -- & .6800 & -- & $\begin{array}{l}\text { RW from short core / } \\
\text { new data }\end{array}$ \\
\hline $\begin{array}{l}\text { Pocomoke } \\
\text { Sound }\end{array}$ & PC3B & 11.4 & $3750.741 \mathrm{~N}$ & 75 48.745W & May 15, 2001 & Piston & 177 & -- & 200 & 20 & -- & -- & 1.6667 & -- & .5667 & -- & $\begin{array}{l}\text { RW peak est from } \\
\text { forams / new data }\end{array}$ \\
\hline $\begin{array}{l}\text { Pocomoke } \\
\text { Sound }\end{array}$ & PC4B & 27.3 & $3748.300 \mathrm{~N}$ & $7550.301 \mathrm{~W}$ & May 15, 2001 & Piston & 122 & -- & 37.5 & 7.5 & -- & -- & .3125 & -- & 1063 & -- & New data \\
\hline $\begin{array}{l}\text { Pocomoke } \\
\text { Sound }\end{array}$ & PC6B-1\&2 & 15.3 & $3744.913 \mathrm{~N}$ & $75^{\circ} 52.333 \mathrm{~W}$ & Sept 18, 2001 & Piston & 476 & -- & 240 & 20 & 450 & 476 & 2.0000 & .5172 & .6800 & 2793 & $\begin{array}{l}\text { RW from short core / } \\
\text { new data }\end{array}$ \\
\hline
\end{tabular}




\begin{tabular}{|c|c|c|c|c|c|c|c|c|c|c|c|c|c|c|c|c|c|}
\hline Region & Core & $\begin{array}{l}\text { Water } \\
\text { depth } \\
(\mathrm{m})\end{array}$ & $\begin{array}{l}\text { Latitude } \\
\text { (degrees) }\end{array}$ & $\begin{array}{l}\text { Longitude } \\
\text { (degrees) }\end{array}$ & $\begin{array}{l}\text { Date } \\
\text { cored }\end{array}$ & $\begin{array}{l}\text { Coring } \\
\text { method }\end{array}$ & $\begin{array}{l}\text { Core } \\
\text { length } \\
(\mathrm{cm})\end{array}$ & $\begin{array}{c}\text { Depth } \\
\text { to } \\
{ }^{137} \mathrm{Cs} \\
\text { peak } \\
(\mathrm{cm})^{1}\end{array}$ & $\begin{array}{l}\text { Depth } \\
\text { to } \\
\text { rag- } \\
\text { weed } \\
\text { peak } \\
(\mathrm{cm})^{2}\end{array}$ & $\begin{array}{l}\text { Depth } \\
\text { range } \\
\text { of } \\
\text { rag- } \\
\text { weed } \\
\text { peak } \\
(\mathrm{cm})\end{array}$ & $\begin{array}{l}\text { Depth } \\
\text { to } \\
{ }^{14} \mathrm{C} \\
950 \\
\text { yr } \\
\text { date } \\
(\mathrm{cm})\end{array}$ & $\begin{array}{c}\text { Age } \\
{ }^{14} \mathrm{C} \\
\text { date } \\
(\mathrm{yr} \mathrm{BP})^{3}\end{array}$ & $\begin{array}{c}\text { Mean } \\
\text { annual } \\
\text { lin. } \\
\text { sed. rate } \\
\text { post- } \\
\text { RW } \\
\text { (cm/yr) }\end{array}$ & $\begin{array}{l}\text { Mean } \\
\text { annual } \\
\text { lin. sed } \\
\text { rate } \\
\text { pre-RW } \\
(\mathrm{cm} / \mathrm{yr})\end{array}$ & $\begin{array}{l}\text { Post-RW } \\
\text { sed. flux } \\
\left(\mathrm{g} / \mathrm{cm}^{2} \mathrm{yr}^{-1}\right)\end{array}$ & $\begin{array}{l}\text { Pre-RW } \\
\text { sed. flux } \\
\left(\mathrm{g} / \mathrm{cm}^{2} \mathrm{yr}^{-1}\right)\end{array}$ & Comments/sources \\
\hline $\begin{array}{l}\text { Parker Creek/ } \\
\text { Choptank }\end{array}$ & PRCK-1-P-1 & 10.7 & $3832.8657^{\prime} \mathrm{N}$ & 76 28.7112W & Sept. 23, 1996 & Piston & 315 & -- & 46 & 6 & 141 & 950 & 0.3833 & 0.1080 & 0.1303 & 0.0583 & $\begin{array}{l}\text { New age model / } \\
\text { Cronin and others } \\
(2000)\end{array}$ \\
\hline $\begin{array}{l}\text { Parker Creek/ } \\
\text { Choptank }\end{array}$ & PRCK-3-P & 24.3 & $3832.6359^{\prime} \mathrm{N}$ & $7625.6199 w$ & Oct. 9, 1996 & Piston & 452 & -- & 5 & 0 & 160 & 950 & .0417 & .1761 & .0142 & .0951 & $\begin{array}{l}\text { New age model / } \\
\text { Cronin and others } \\
(2000)\end{array}$ \\
\hline $\begin{array}{l}\text { Potomac } \\
\text { Transect }\end{array}$ & PTMC-3 & 23.1 & $3801.6118^{\prime} \mathrm{N}$ & 76 13.1938W & Sept. 25, 1996 & Piston & 452 & 29 & 77 & 6 & 278 & 950 & .6417 & .2284 & .2182 & .1233 & $\begin{array}{l}\text { Cronin and others } \\
(2000)\end{array}$ \\
\hline $\begin{array}{l}\text { Patuxent } \\
\text { Transect }\end{array}$ & PTXT-2-P-3\&5 & 11.5 & $3819.584 ' \mathrm{~N}$ & $7623.548^{\prime} \mathrm{W}$ & June 20, 1998 & Piston & 400 & -- & 101 & 10 & 397 & 609 & .8417 & .5492 & .2862 & .2965 & $\begin{array}{l}\text { Cronin and others } \\
(2000)\end{array}$ \\
\hline $\begin{array}{l}\text { Patuxent } \\
\text { Transect }\end{array}$ & PTXT-3-P-2 & 22.5 & $3820.0007^{\prime} \mathrm{N}$ & $7618.5801 \mathrm{~W}$ & Sept. 20, 1996 & Piston & 432 & -- & 11 & 5 & 59 & 950 & .0917 & .0545 & .0312 & .0295 & $\begin{array}{l}\text { Uppermost E Hol } \\
14 \mathrm{C} \text { date used / } \\
\text { new data }\end{array}$ \\
\hline $\begin{array}{l}\text { Patuxent } \\
\text { Transect }\end{array}$ & PTXT-4-P & 15.5 & $3821.480 \mathrm{~N}$ & $7620.251 \mathrm{~W}$ & June 1, 1999 & Piston & 500 & -- & 10 & NA & 67 & 950 & .0833 & .0648 & .0283 & .0350 & $\begin{array}{l}R W \text { is }<20 \mathrm{~cm} \text { depth / } \\
\text { new data }\end{array}$ \\
\hline Potomac River & WICO-1 & 9.8 & $3816.769 \mathrm{~N}$ & $7649.369 \mathrm{~W}$ & $\begin{array}{l}\text { Sept. 19-20 } \\
2001\end{array}$ & Piston & 210 & -- & 129 & -- & 135 & 300 & 1.0750 & .0261 & .3655 & .0141 & New data \\
\hline
\end{tabular}

\footnotetext{
${ }_{1}^{1}$ Approximately 1963-64.

$21880+/-20$ years Willard and others, 2003.

${ }^{3}$ Age in calendar years before present (1950) using CALIB 4.1 program.
} 
Third, independent researchers using different methods have produced generally similar quantitative estimates of sediment rate and flux, regardless of the scope of the study. This fact indicates a high degree of confidence that the values given in tables 6.1 and 6.2 are relatively accurate and support the conclusions of several prior researchers (for example, Kerhin and others, 1988; Donoghue, 1990; Halka, 2000).

Three major hypotheses about the patterns of sedimentation in the Chesapeake Bay estuary have emerged over the past few decades largely on the basis of historical patterns. These concern (1) sediment trapping in the ETM zone, (2) tributary and bay "import export" of sediment, and (3) legacy sediments. These concepts are so pervasive in the bay community that it is useful to summarize their basic tenets and mention some uncertainties surrounding them.

The northern main stem bay and larger tidal tributaries have an ETM zone-a region where fine-grained particulate material is "trapped," deposited, and, sometimes resuspended and redeposited. It generally is believed that the majority of fine-grained river-borne sediment is trapped in ETM zones and only escapes the upper reaches of the northern bay (or upper parts of tributaries) during extreme hydrological events. Most studies of the ETM zone have focused on relatively short time scales (sub-annual to interannual).

The ETM zone hypotheses explain many aspects of observed suspended material in the bay and its tributaries; however, it should be noted that other studies have indicated more sediment may be "escaping" the ETM zone than previously believed. For example, certain geochemical tracer data indicate sediment has been transported over longer time scales than current studies would indicate from the northern bay to at least to the midbay (Darby, 1990; Helz and others, 2000). In the main stem bay, Schubel and Pritchard (1986) estimated that the ETM zone migrates $40-55 \mathrm{~km}$ seaward during flood events, which would lead to southward export of a least some Susquehanna River sediment. On the basis of isotopic analyses of sediments from the central main stem bay, Helz and others (2000) concluded that the source of some mid-bay sediment was the Susquehanna River. These studies suggest that sediment "escapes" the ETM zone, which is especially important because the processes involve mainly fine-grained suspended sediments of most concern for water clarity.

The second hypothesis about sedimentation can be referred to as the tributary "import-export" hypothesis. This idea holds that there is a net import of sediment from the main stem bay into larger tidal tributaries except during extreme high flow events when some sediment is exported from tributaries to the main stem. The tributary importexport hypothesis is an idea that has not been tested in detailed field studies to the extent that quantitative estimates of import-export can be derived for each tributary. In the Rappahannock River estuary, Nichols (1977) indicated 10 percent of the sediment discharged by Hurricane Agnes in 1972 escaped the Rappahannock River into the bay. In the York River system, the sediment load near Gloucester Point (about $10 \mathrm{~km}$ upstream of the estuary mouth) typically involves landward transport of sediment (J. Herman, Virginia Institute of Marine Science, oral commun., 2003), whereas seaward transport is associated with episodic, energetic events such as storms and hurricanes (Gao and Collins, 1997; Geyer and others, 2001). Satellite data also show export of suspended material from tributaries into the bay during relatively wet periods (Stumpf, 1988). Bottom-sediment surveys in the southern bay (Byrne and others, 1980) and other lines of evidence (Officer and Nichols, 1980; Lukin, 1983) also indicate the hypothesis is true.

The issue of import/export to and from tributaries also pertains to the issue of sediment sources to the mid-bay, a region where input of suspended material from the north (mostly Susquehanna River inflow) and ocean-source sediment from the south are thought to contribute relatively small proportions of the total sediment flux. Although Officer and others (1984) concluded that sedimentation rates in the central main stem of the bay were lower than those in the northern and southern bay, there is nonetheless a thick accumulation of Holocene sediment in many parts of the central bay. If northern and southern sources are minor in the mid-bay, then it is difficult to account for the thick accumulation of sediment in parts of the main stem of the central bay, even with large contributions from shoreline erosion. Export from the northern ETM zone, import of finegrained sediment from the southern bay, and sediment export from tributaries all contribute to sediment flux into the central bay, although the relative contributions of each have not been quantified. 
The third major hypothesis pertains to the effect of large-scale deforestation from agriculture and timber production on sediment flux to the bay. This hypothesis commonly is expressed in the idea of "legacy" sediment-a concept derived largely from studies of fluvial systems. It implies that part of the sediment originating from cleared lands has been trapped in transit in rivers and the upper parts of tributaries and has not yet reached the lower reaches of tidal tributaries or the Chesapeake Bay itself.

Although land clearance in the Chesapeake Bay watershed has no doubt led to large-scale erosion, it is still not known what proportion of sediment eroded since land clearance began remains trapped in uplands and stream channels, and how much has been transported to the lower tidal reaches of tributaries or to the main stem of the bay. Several studies have concluded that sedimentation rates and fluxes have increased from between three- to tenfold as a result of extensive 18th- and 19th-century land clearance. It has been suggested that this human-induced historical increase in sediment flux is manifested in the high rates of sedimentation measured in the upper parts of tributaries where most of the eroded sediment is deposited.

A possible indicator for depositional events is paleoecological evidence from the central bay for historical degradation in phytoplankton communities (diatoms in Cooper and Brush, 1993; dinoflagellates in Willard and others, 2003). However, some phytoplankton communities also are influenced strongly by eutrophication, and it is difficult to separate the effects of increased turbidity. Except for the few studies of the paleoecology in the main stem, field studies of sedimentation during the past few centuries have focused on relatively small sub-estuaries and include little or no data on sediment accumulation downstream in more distant regions (Defries, 1986). Moreover, as described below, published pre-colonial rate comparisons are based on poorly dated Holocene sediments and should not be used for evaluating temporal variability in rates. Consequently, the effect of land clearance on diminished water clarity and bay faunas and floras is uncertain.

One way to address the issue of land-use effects on sedimentation in Chesapeake Bay is to compare pre-colonial "natural" and historical (since 1880) sedimentation flux estimated from sediment cores obtained on cruises between 1996 and 2002. As part of a larger study of sedimentation in Chesapeake Bay, the USGS tested the hypothesis that land-use changes have led to largescale increases in sedimentation. The analysis used pollen stratigraphy of core samples and calibrated radiocarbon ages to evaluate rates of sedimentation over the last thousand years within different regions of the bay (table 6.1).

The peak abundance of ragweed (Ambrosia) pollen in sediment cores was used as an age marker for the period from A.D. 1880 to 1900. Peak ragweed abundance has been dated directly using short-lived radioisotopes in several sediment cores and it correlates with historical records of maximum timber production and large-scale land clearance about from 1880 to 1900 A.D. (Brush, 1989; Willard and others, 2003). It should be emphasized that the ragweed peak used for dating is not the same as the initial rise in ragweed pollen, which is a valuable time marker used in many studies to date the earlier 18th-century land clearance. The temporal variability in the percentage of ragweed pollen in core MD99-2209 from the channel off the mouth of the Rhode River is shown in figure 6.3. The pre-historical value of about 1 percent rose to near 15 percent during the ragweed period. The midpoint of the ragweed maximum between 201$241 \mathrm{~cm}$ was used to calculate sediment flux since about $1890 \mathrm{AD}$. There is some subjectivity in identifying the ragweed peak due to variability in sedimentation at different core sites, and processes of pollen transport and deposition. This event is nonetheless a useful time marker for obtaining a first approximation of the mean annual sediment flux during the past 100 years or so.

For each core, a linear age model for the sedimentary sequence deposited prior to the ragweed peak was developed using radiocarbon dates on marine-estuarine mollusk and foraminiferal shells. Radiocarbon ages based on total organic carbon material gave ages about 1500 - 2000 years too old because of "old carbon" and were not used (Colman and others, 2001). An age-depth model for core MD99-2209 from the main channel off the mouth of the Rhode River is shown in figure 6.4. The linear age model has a correlation coefficient $\left(\mathrm{r}^{2}\right)$ of 0.98 . The stratigraphic position of the maximum proportion of ragweed pollen also is shown. It can be seen that the stratigraphic interval near $540-550 \mathrm{~cm}$ core depth is dated at about $1000 \mathrm{yr}$ B.P. Thus, for core MD99-2209, about $300 \mathrm{~cm}$ of sediment accumulated between 1000 and 1880 A.D. (between 550 and $260 \mathrm{~cm}$ core depth). 


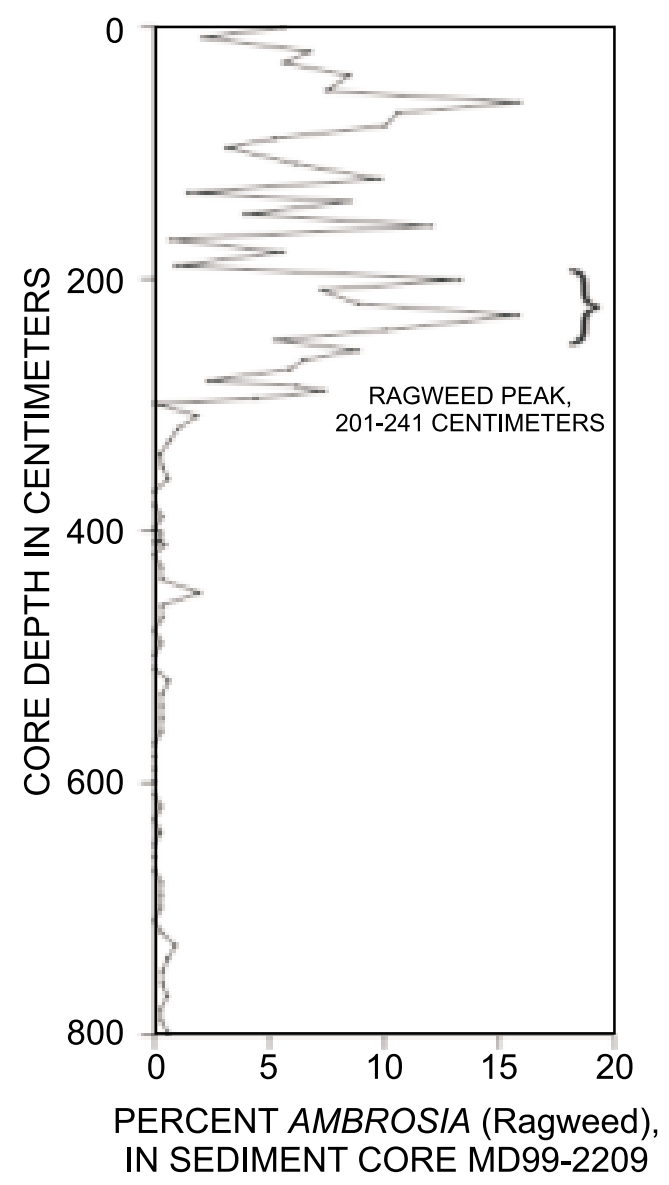

Figure 6.3. Proportion of ragweed (Ambrosia) pollen in core MD99-2209 showing the peak in ragweed between 201-241 centimeters depth corresponding to maximum agricultural and timber production land clearance (Modified from Willard and others, 2003).
Using these methods to estimate mean annual sedimentation rate, linear accumulation rates for the post-1880 and pre-1880 intervals were converted into mass flux for each sediment core. The sediment flux in 16 cores for which only historical sediment fluxes were calculated based on sediment thickness above ragweed peak is shown in figure 6.6. A comparison between pre- and post1880 rates for 24 cores is shown in figure 6.5. The patterns seen in figure 6.5 confirm observations from prior studies discussed above that historical sedimentation rates vary by about an order of magnitude throughout the bay area (from less than 0.1 to $\left.0.8 \mathrm{~g} \mathrm{~cm}^{-2} \mathrm{yr}^{-1}\right)$. Some of the highest rates were in Pocomoke Sound (PC6B), the northern main channel (MD2209), and off the mouth of the Little Choptank River (LCHPT-1-P-4\&5). Some of the lowest rates were in the Potomac River tributary (NKL-12-1 and NKL-16-1).

Some sites (for example, MD99-2209) have about a four-fold greater sediment flux during the last century than during the prior 1,000 years (fig. 6.5). These results confirm the general conclusions of other studies of sediment cores for the central main stem discussed by Cooper and Brush (1991), Cronin and others (2000), and Colman and Bratton (2003). However, at many sites the historical rates have been roughly equal to or have exceeded pre-historical (1000-1880 A.D.) rates.

There are several possible explanations of these results. The most likely explanation is that prior paleoecological studies were, by design, focused on regions in the bay characterized by fairly continuous sedimentation and relatively high sedimentation rates at least at interannual time scales (bay sediments usually do not preserve seasonal patterns of sediment). High sedimentation rates and continuous accumulation provide a high temporal resolution with minimal gaps in the stratigraphic record and are ideal for paleoecology and the reconstruction of ecosystem history at decadal and centennial time scales. However, using only cores with continuous sedimentation and stratigraphy introduces a bias when evaluating spatial patterns of sedimentation, because areas of slow accumulation or erosion are excluded. The results presented in figures 6.5 and 6.6 clearly include core sites where relatively little sediment has accumulated (or has accumulated and has since been eroded) during historical time. The evidence suggests that pre-historical sedimentation at some of these sites was as rapid as during historical time. 


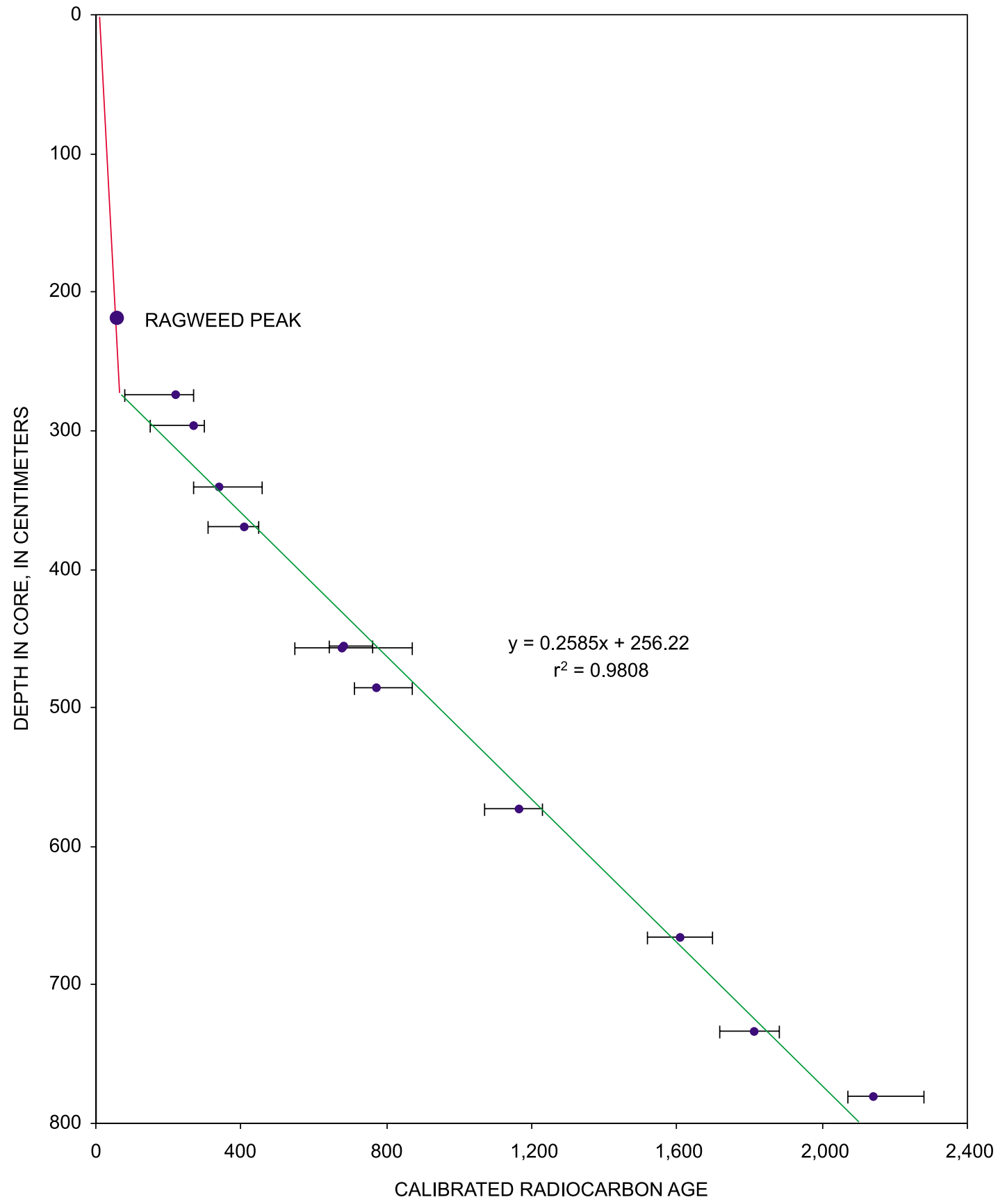

Figure 6.4. Age-depth model for core MD99-2209 showing series of radiocarbon ages (calibrated to years before 1950) and 2 sigma error bars. 


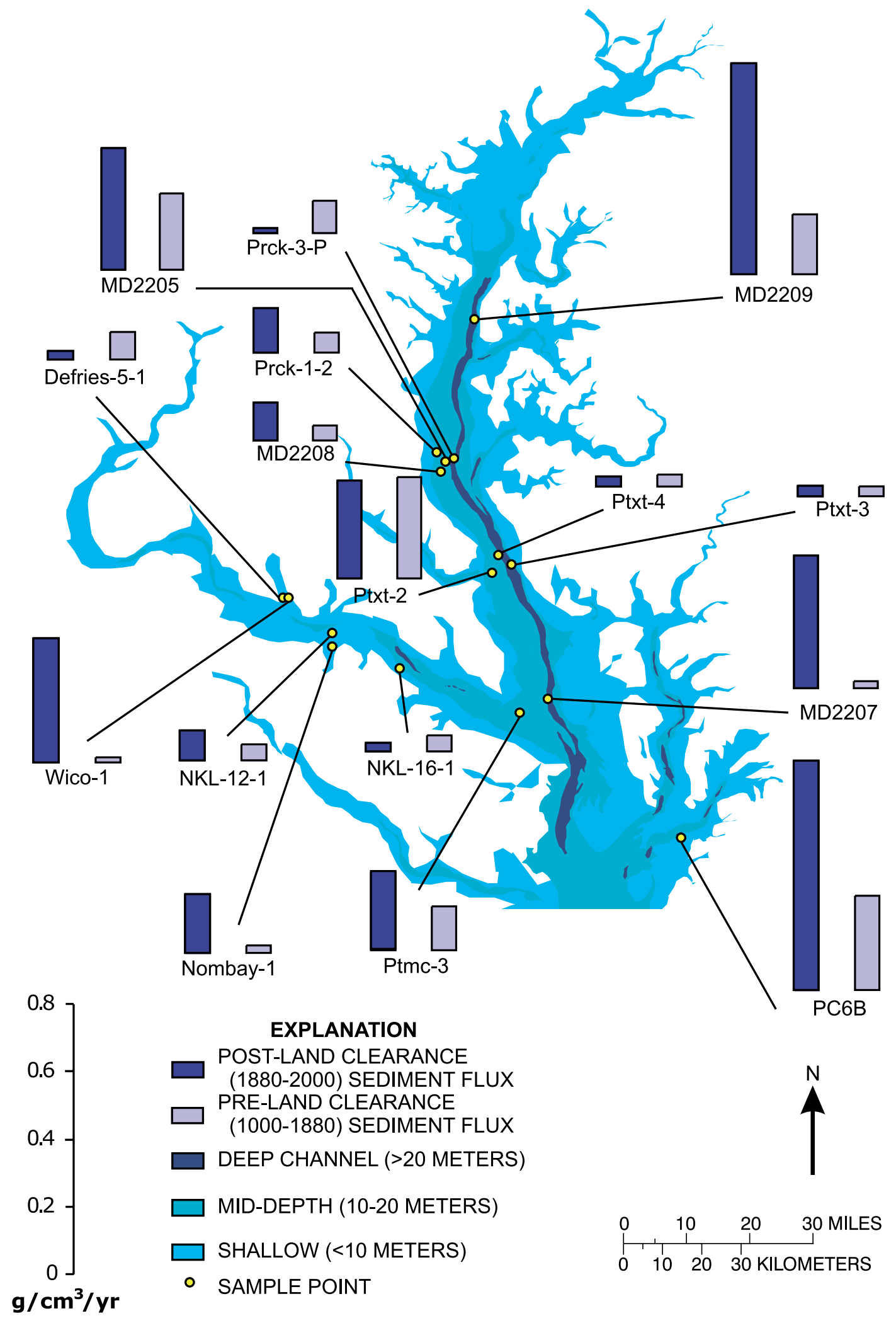

Figure 6.5. Comparison of historical (1880-present) and long-term sediment flux at core sites in Chesapeake Bay (determined by methods and data described in table 6.1). 


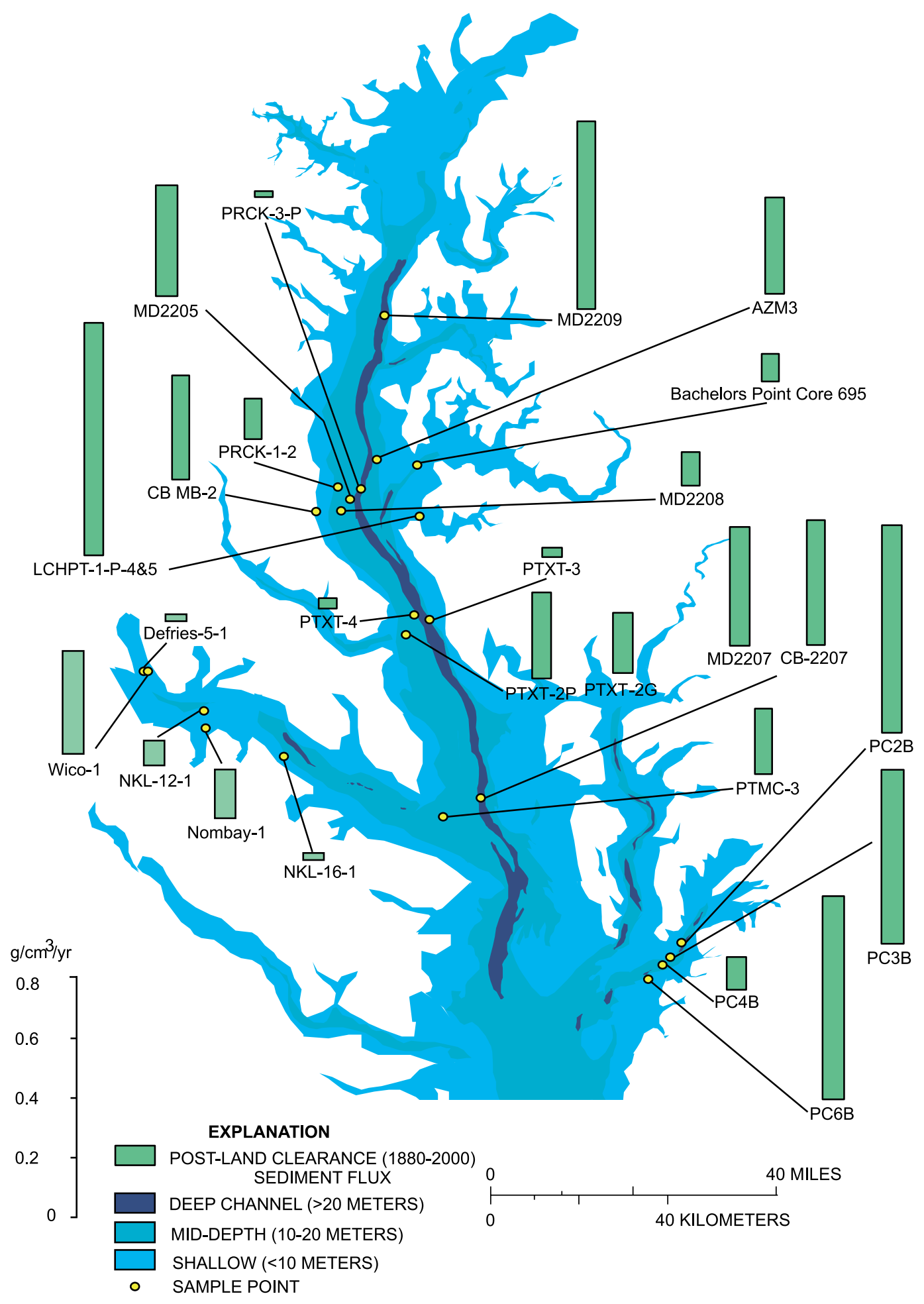

Figure 6.6. Estimates of sediment flux at different core sites in the Chesapeake Bay, calculated by determining the amount of sediment lying above the peak in ragweek pollen and converting to mass (based on data in table 6.2). 
Another possible factor is that the physical processes, such as tides, currents, and estuarine circulation change, over decades to centuries altering sedimentation. Erosion and deposition of sediment is extremely dynamic and variable over seasonal and interannual time scales in some parts of Chesapeake Bay such as the York River. Large-scale shifts in sediment deposition and erosion also occur over millennial time scales in Chesapeake Bay as illustrated by the common occurrence of stratigraphic unconformities representing temporal gaps of several thousand years (Cronin and others, 2000).

It is important to emphasize that this analysis was limited to sedimentation in the central bay region at water depths of about 6-25 $\mathrm{m}$ and these rates cannot be extrapolated to shallower water or to the more proximal reaches of tributaries. Nonetheless, the results indicate that the effect of historical factors on sediment and water clarity cannot be extrapolated from one region to the entire bay. These results also highlight a need for focused research on sediment flux, land use, and physical processes in the most critical habitats and regions of the bay.

\section{Sediment Resuspension}

Bottom sediments in the Chesapeake Bay can be resuspended in response to tidal currents, waves, and boating traffic and can be a significant source of the sediment load in the water column, potentially increasing light attenuation. The amount of sediment introduced to the water column by resuspension is highly variable spatially and temporally. Moreover, the ways physical forcing mechanisms generate suspended sediment are complex, and the transport of the particles subject to resuspension, including their settling rates and eventual redeposition on the bottom, is only partially documented. In different parts of the estuarine system, the relative importance of the major mechanisms controlling resuspension can be significantly different. This section presents the current understanding of sediment resuspension in the bay.

The importance of tidal resuspension in finesediment regions of Chesapeake Bay and its tributaries has long been recognized (Sanford and Halka, 1993; Schubel, 1968a; Schubel, 1969). Recent study of the upper Chesapeake Bay ETM zone led Sanford and others (2001) to conclude that asymmetrical tidal resuspension and transport prima- rily are responsible for the maintenance of the ETM zone at the limit of salt intrusion. This is in contrast to early studies that ascribed the formation of the ETM zone to gravitational circulation patterns. They also confirm the importance of resuspension processes to the maintenance of this zone of high concentrations of suspended sediment and associated light attenuation. Without the effects of tidal resuspension, the rapidly settling aggregates of fine particles would remain on the bottom. Tributary estuaries of the Chesapeake Bay system also are characterized by one, or occasionally two, ETM zones (Lin and Kuo, 2001; Nichols, 1974). Tidal resuspension in the relatively sediment-starved mid-estuary below the ETM zone is weaker but still significant (Ward, 1985).

Wave-forced resuspension coupled with wave-induced shoreline erosion in shallow (less than $2 \mathrm{~m}$ deep) parts of the estuarine system generally is understood to produce significant amounts of suspended sediment in the water column. However, relatively few site-specific studies of this topic have been conducted to date (Wilcock, 1998). Those that are available are applicable only to a particular location and time frame. Their results cannot be extrapolated to the larger estuarine system, due, in part, to the variable geometry of the Chesapeake Bay that results in both variable fetch and wide ranges in nearshore bathymetry. Fetch influences the ability of local winds to generate waves; local variations in bathymetry influence the direction and energy of waves approaching shallow-water zones and shorelines.

In the relatively deeper waters of the Chesapeake system, wave-forced resuspension may be significant under storm conditions and can dominate the normal tidally induced resuspension signal (Sanford, 1994; Ward, 1985; Wright and others, 1992). The influence of wind-wave bottom shear stresses on sediment resuspension and subsequent transport can be projected with advances in computational power and numerical modeling techniques (Lin and others, 1997; Lin and others, 2002). Computer simulations suggest that wind-generated waves can produce significant bottom shear stress, resulting in sediment resuspension. After the physical forcing associated with the stormwave energy is reduced, the resuspended sediments settle rapidly to the bottom. The sediments exhibit increased erodibility for some period of time thereafter (Sanford, 1994), thus increasing the likelihood of subsequent transport by lower energy tidal currents. 
A similar dependence of bottom-sediment grain size with storm-wave bottom shear stress has been observed in intermediate water-depths in the Chesapeake Bay (Nakagawa and others, 2000). In that study, the bottom-sediment grain size was related to strong wind events that occurred less than 5-percent of the time, not to the mean wind speed for the area. The results of these studies point to the importance of infrequent high-energy events in sediment resuspension, transport, and eventual distribution on the bottom of the Chesapeake Bay. In the vicinity of the bay mouth, longperiod swell waves with increased bottom shear stress enter from the Atlantic Ocean and are likely to resuspend more bottom sediment than storm waves further up the estuary (Boon and others, 1996; Wright and others, 1992). These higher energy waves in the southern bay could also influence the formation of the secondary turbidity maximum in the York and similar southern bay subestuaries (C. Friedrichs and L. Schaffner, oral commun., 2003).

In an effort to examine the relative magnitude of tidal resuspension as an instantaneous source of TSS in the upper bay, L. Sanford (University of Maryland, Center for Environmental Science, written commun., 2003) provided the SWGP with estimates of the amount of sediment resuspension that occurs on a daily basis in the northern Chesapeake Bay. These estimates are summarized below because of their significance to the question of sediment resuspension. Note that these results were generated for the main ETM zone of the bay, not the entire estuary. The estimates include an estimated volume of water in the ETM zone (from the mouth of the Susquehanna River south to Tolchester), the average background concentrations of suspended sediment, or that which is present irrespective of currents and bottom shear stress, and the resuspended sediment concentration in that water volume. Using these values,

the TSS load in the ETM zone is estimated to be approxi-mately 135,000 metric tons (MT) during maximum tidal resuspension. This includes 90,000 MT of resuspended TSS per tidal cycle and 45,000 MT of back-ground TSS. The estimated loading rate due to tidal resuspension is $180,000 \mathrm{MT}$ per day, but this material also is redepos-ited twice per day. This can be compared to the estimated combined sediment input of 4,400 MT per day to this area of the bay from the Susquehanna River, shoreline erosion, and internal productivity of 4,400 MT per day.

The relatively large value attributed to sediment resuspension is due to multiplication of a small number for suspended material per unit bottom area times the relatively large bottom area of the northern bay. A few caveats apply to these estimates. The estimates were based on only a small number of study sites primarily in deeper waters of the ETM zone, such that the estimated total load of resuspended material must be considered very preliminary. It is not clear how much of the resuspended deep-water sediment can be transported laterally into shallower areas of the estuary. Resuspended sediments tend to be more aggregated and thus settle back to the bottom quickly, only to be resuspended again in the next tidal cycle. This continued process of deposition followed by resuspension results in the large total loads that are calculated, but it also results in relatively shortlived peaks in resuspended sediment concentration that are most pronounced near the bottom. It should be noted that the sediment concentrations that result from resuspension are not from new sediment being introduced to the system during each tidal cycle, but are instead a recycling of material already in place.

Despite the uncertainties, a major conclusion that can be drawn from these estimates is that normal bottom-sediment resuspension processes could be the dominant instantaneous source for the suspended sediment load in the water column, when considered in a highly averaged spatial context.

In addition to natural processes of waves, currents, and tides, boating activity also can cause sediment resuspension. A study of boat-wake effects on shore erosion in an area of high recreational boat use showed that boat wakes generated less incident energy than normal wind-generated waves (Zabawa and Ostrom, 1980). The major factor influencing shore erosion was a single storm event during the study period, followed by wind waves associated with normal wind levels. Recreational boating undoubtedly has increased throughout the bay region since that study, but it remains unclear how significant the effect of boat wakes may be on resuspension in nearshore areas. It is possible that larger effects result from repeated generation of boat wakes during periods of high recreational vessel use, such as summer weekends. 
The effects from the passage of large commercial ships has not been studied in the Chesapeake and could be locally important because of the higher energy waves produced by these ships. However, the relatively infrequent passage of these ships would suggest that their importance is minimal relative to wind-generated waves.

In summary, the ability to control resuspension in the Chesapeake Bay that results from tidal currents and storm-generated waves is limited because of the extremely widespread sediment source (for example, the entire bay bottom). However, the processes that lead to sediment resuspension and subsequent transport into sensitive habitat zones need to be more fully understood through direct measurement coupled with the development of computer models that simulate resuspension in response to known physical mechanisms. With appropriate parameterizations repre- senting sediment resuspension, deposition, consolidation, and bed armoring, these models could provide an understanding of where management actions can be most effective. The ability to reduce resuspension may be limited to in-situ practices, such as breakwaters to reduce wave energy or the reestablishment of a significant population of filter feeding oysters, that can be effective in removing sediment from the water column. It has been suggested that relatively high levels of resuspendable sediment in the estuary may, in part, be a legacy of high sediment inputs from the watershed over the past few hundred years. Continued efforts to reduce sediment input from the watershed eventually will reduce the pool of resuspendable sediment in the estuary itself, although there will probably be a significant time lag before any positive benefits are noted. 


\section{CHAPTER 7. INTEGRATED APPROACHES TO SEDIMENT STUDIES}

\author{
by Sean Smith, ${ }^{1}$ Julie Herman, ${ }^{2}$ \\ Thomas Cronin, ${ }^{3}$ Gregory Schwarz, ${ }^{3}$ \\ Michael Langland, ${ }^{3}$ Kenn Patison, ${ }^{4}$ \\ and Lewis Linker ${ }^{5}$
}

\section{Sediment Budgets: Watershed and Estuary}

In this section, information related to the development of sediment budgets for the entire bay, a tributary, or a watershed are summarized. A sediment budget is a conceptual simplification of the interactions between physical processes involved in the conveyance (movement) of sediment downstream (Dietrich and others, 1980). The concept of developing a sediment budget is based on the conservation of mass by accounting for sediment sources, sinks, and yield (output) within a watershed system (fig. 7.1). The fact that mass is conserved theoretically provides a strong constraint on budgets by requiring that inputs, storage, and outputs be quantitatively balanced so there is no unaccounted mass (Wilcock, 2002). The mass balance approach is used to compensate for the inability to obtain physical data for every part of study area.

The construction of a budget is helpful for developing linkages between erosion in upland areas with subsequent sediment delivery downstream (Trimble and Crosson, 2000). Sedimentbudget information can be used to evaluate the effects of natural and unnatural disturbances on sediment production and yield in the Chesapeake Bay watershed. In addition, sediment-budget information can be used to predict the effects of land-use changes in the watershed on sediment yield, to determine best-management practices, and to guide the development of diagnostic tools to formulate strategies for land-use planning.

Although the general idea of a watershed sediment budget is not new, there is an increased awareness in recent years that the residence time of sediments within a drainage basin may be an important factor in determining the response of

\footnotetext{
${ }^{1}$ Maryland Department of Natural Resources.

${ }^{2}$ Virginia Institute of Marine Science.

${ }^{3}$ U.S. Geological Survey.

${ }^{4}$ Pennsylvania Department of Environmental Protection.

${ }^{5}$ U.S. Environmental Protection Agency.
}

river and estuarine systems to short-term land-use changes (Phillips, 1991a). Improved understanding and quantification of the complex relations between sediment source and storage components through the development of a sediment budget also enhances the ability to generate estimates of watershed sediment residence time. The temporal and spatial scales applied to a sediment budget ultimately will determine what factors govern the flux of sediment. For large spatial or long temporal scales, the process-based budgeting approach can be used to evaluate the effect of long-term climatic change on sediment production and yield to the Chesapeake Bay. On smaller spatial and temporal scales, development of sediment budgets for small watersheds can be used to evaluate cumulative and short-term effects of land-use modifications and best-management practices in disturbed landuse settings.

\section{Watershed Components}

Watershed components of a sediment budget may be described as upland erosion, upland storage, wetland and (or) floodplain storage, channel storage, streambank erosion, and load or yield at the basin outlet. Many of these components and processes are discussed in previous chapters. Within a watershed, the function and roles of sediment sources and sinks relative to total-basin sediment yield can be highly variable, particularly when land use has changed significantly over time (Trimble, 1999). As a single flux term, large-scale watershed sediment yield has limited value because of the difficulties in establishing linkages with well-defined processes and in determining sediment residence times in the watershed. Partitioning the components of a budget into functional zones, such as sediment production, transfer, and storage areas, can improve the estimation of the relative influence of localized landscape settings and land-use changes on overall sediment yield.

Development of techniques that facilitate the rigorous evaluation of the sources and sinks in a sediment budget is important for budget accuracy. However, assembling the data necessary for such accuracy is difficult (Walling, 1994). Balancing the budget to obtain accurate estimates of watershed sediment yield requires that the error within each component be minimized. The benefits of reducing error should be weighed against increased monitoring costs and transferability of site-specific results. 


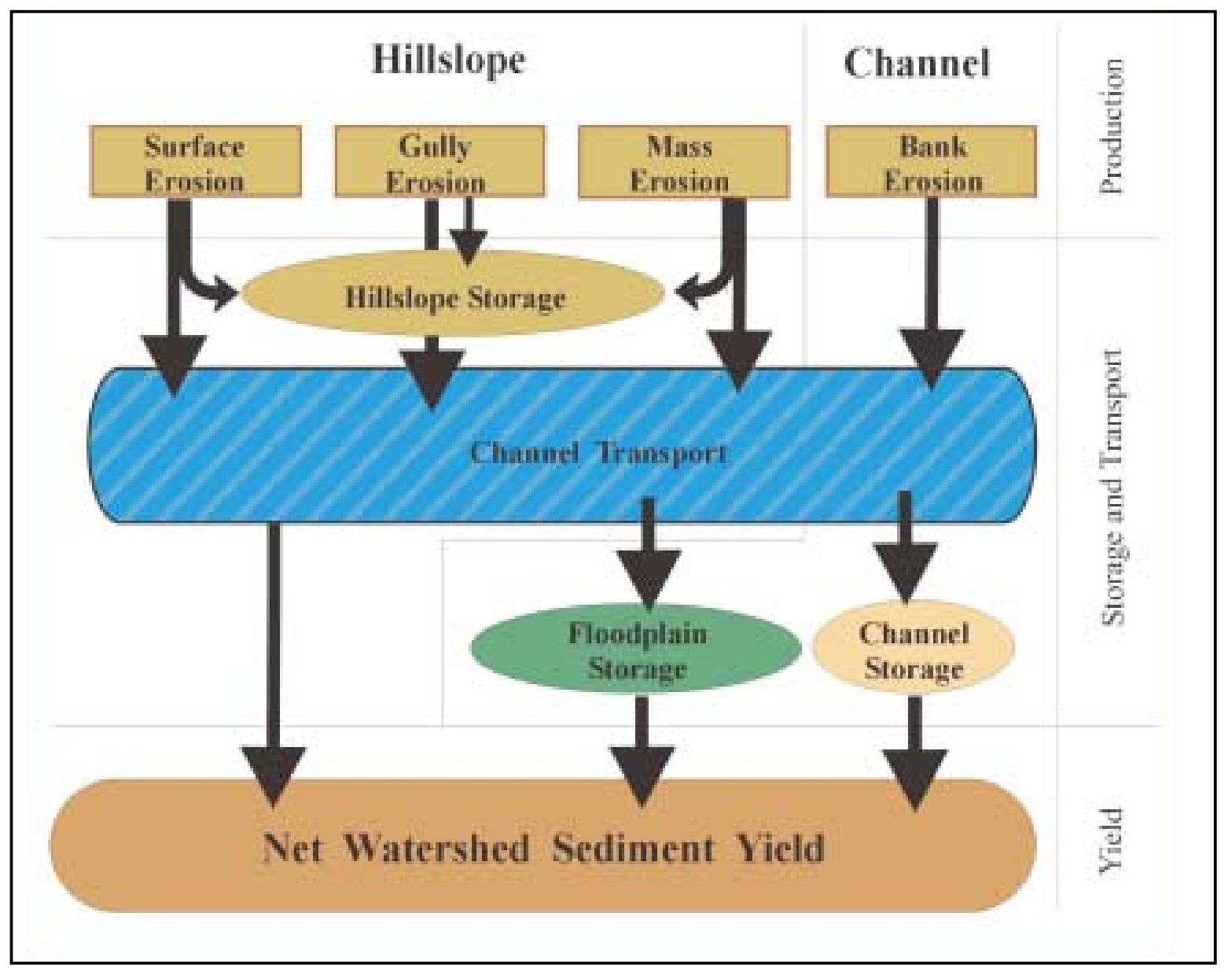

Figure 7.1. Watershed sediment, sinks and sources (Modified from Jacobsen and Coleman, 1986).

Sediment budgets can be compiled for a wide spectrum of spatial and temporal scales and the relevance of the components directly relate to the spatial and temporal scales under consideration. Spatial scales can range from small (channel reach and shoreline lengths of several to hundreds of meters) to watersheds draining small areas of about 0.5 to $1 \mathrm{mi}^{2}$, to watersheds over $100 \mathrm{mi}^{2}$, up to large basins the size of the Chesapeake Bay drainage basin. Sediment erosion is sometimes estimated with reference to 10,000 to 1 million years because of the relevance to the long-term evolution of modern topographic conditions. Chesapeake Bay sediment fluxes commonly are evaluated over time periods from 100 to 10,000 years because of the relevance to sea-level changes, human effects under the current (2003) climatic conditions, and a management perspec- tive. Sediment loadings from land disturbance usually focus on short-term and instantaneous events such as individual storms.

The physical processes controlling sedimentbudget components also can vary with time. These changes in physical processes can contribute to biases in results when interpreting data sets that span different periods of time (Johnson, 1990). Temporal and spatial scales should be compatible in a budget to produce robust results and practical interpretations (Campbell, 1992). Because an understanding of the present-day system is needed for management purposes, budget components commonly are calculated on an annual basis using information from decadal time scales. However, budgets based on annual averages are not designed to describe large sediment movements during relatively short time intervals (Kleiss, 1996). In the Chesapeake Bay watershed, sediment loadings associated with European colonization and 
land-clearing activities generally are discussed relative to time scales of 1 to 3 centuries. The response of the landscape to land clearing and the resulting increases in sediment supply can be evaluated on the basis of geomorphic changes, such as the presence of incised channels, the aggradation of floodplain areas, and infill of tidal estuaries. However, sediment remobilized from long-term storage areas can be wrongly identified as generated from recent erosion in upland areas within a basin (Campbell, 1992).

In general, a comprehensive understanding of sediment transport and fate is considered essential for developing a sediment budget and designing and implementing effective plans for sediment management (Osterkamp and others, 1998; U.S. General Accounting Office, 1990). The accuracy of sediment-flux estimates is compromised by inherent uncertainties in measuring sediment concentrations and by the highly episodic nature of sediment movements, particularly when evaluating smaller basins. However, for annual or decadal flux estimates, the methods generally are reliable if calibrated with extended periods of data (Robertson and Roerish, 1999). The Universal Soil Loss Equation (USLE) (Natural Resources Conservation Service, 1983) is an engineering method widely used for estimating sheet and rill erosion. Although receiving substantial support within the literature, the mathematical assumptions of the USLE recently have been questioned (Trimble and Crosson, 2000).

Conversely, relatively little direct evidence is available concerning the fate of sediment. The common practice of quantifying sediment fate with a sediment delivery ratio, estimated from a simple empirical relation with upstream basin area, does not consider the relative importance of individual storage sites within a basin (Wolman, 1977). Rates of sediment deposition (storage) in reservoirs and floodplains can be determined from empirical measurement, but only a limited number of sites have been monitored and net rates of deposition or loss from other potential sinks and sources is largely unknown (Stallard, 1998). In particular, little is known about how much sediment loss from fields ultimately makes its way to stream channels and how much sediment subsequently is stored in or lost from the streambed (Meade and Parker, 1985; Trimble and Crosson, 2000).
In summary, sediment source, storage, and yield components that collectively describe sediment budgets have been quantified by various means in the Chesapeake Bay watershed. However, few comprehensive budgets, composed of multiple components and detailed field measurements, have been compiled. Estimation has been required of one or more components that introduce errors depending on the time scale, setting, and time-period estimation. Integrated studies are lacking that investigate and quantify all components as a complete system at the same spatial and temporal scales. In addition, the relations between smallwatershed sediment processing and large-watershed sediment yield have not been extensively documented in each of the major tributaries draining to the Chesapeake Bay. Therefore, it is difficult to correlate the effects of specific watershed landuse practices on sediment load to the estuary.

\section{Estuarine Budgets}

A sediment budget for the Chesapeake Bay would include inputs from the watershed(s) and estuarine components for shoreline erosion, biogenic production, ocean, storage and re-suspension, and tidal flux at the "outlet." Various researchers have tried to quantify the flux of sediment within the bay and its tributaries using a wide range of methodologies. In reviewing this literature on sediment budgets in the Chesapeake Bay system, an important methodological distinction must be emphasized between those studies that address suspended particulate material in the water column and those that address sediment that has actually accumulated on the bay (tributary) floor. Suspended-sediment data, which includes USGS Fall Line TSS load measurements (Langland and others, 1999), and TSS monitoring data from the bay and tributaries, deals exclusively with particulate material in the water column for a particular time and region. Notable studies of suspended particulates that resulted in sediment budget information include well-known papers by Biggs (1970), Schubel and Carter (1976), and Nichols and others, (1991). Although TSS studies may be of importance to water clarity and the SAV-TSS-light issues discussed earlier in this report, they are not sufficient alone to construct a comprehensive sediment budget.

In contrast, studies directly addressing surficial modern bay-floor sediment accumulation include those by Ryan (1953), Donoghue (1990), Kerhin and others (1983; 1988), Byrne and others 
(1982), and Hobbs and others (1990; 1992). Studies of temporal patterns of sediment deposition based on long sediment cores and geochronological analyses also are relevant to sediment budgets and are described in the section on Sediment Deposition and Sedimentation Rates discussed later in this chapter. Because they are a source of information on long- and short-term sedimentary processes, sediment data from bottom samples and sediment cores are of great utility to management efforts to improve water clarity, and to issues of dredging, contaminants in sediments, and nutrient recycling.

Several comprehensive studies have explicitly attempted to synthesize a bay-wide sediment budget. The original report should be consulted for methods and assumptions and detailed interpretation. Ryan (1953) studied 200 sediment cores throughout the bay and was one of the first to describe the general character of sediments in the modern bay. Ryan showed that sands blanket the bay flanks and that fine-grained silts and clays cover the deeper main channel.

Another early sediment budget developed for the bay used a simple, single-segment model based on salt-flux equations to compute suspended sediment and to estimate exchanges of suspended sediment between the bay and its tributaries and the bay and the ocean (Schubel and Carter, 1976). This study concluded that sediment sources include the Susquehanna River (57 percent), shoreline erosion (32 percent), and sediment moving from the ocean into the mouth of the bay (12 percent). Schubel and Carter estimated the majority of sediment (92 percent) carried into the bay was deposited in the bay itself; the remaining 8-percent was transported from the main stem of the bay into the tidal tributaries. Schubel and Carter concluded that the ETM traps most sediment in the north, tributaries are net sinks of sediment imported from the bay, and the bay is a sink for sediment imported from the ocean. As discussed in the previous chapter, the net export of sediment from the northern to central bay and from the tributaries to the main stem is a complex, unresolved issue in terms of the timing and quantity of sediment movement.

Similarly, the contribution of sediment from coastal marshes is a complex, commonly misunderstood subject. Investigations of sediment flux in brackish marshes include those by Kearney and Ward (1986) and by Stevenson and others (1985). Stevenson and others (1988) calculated that brack- ish estuarine and tidal freshwater marshes trap about 5 to 11-percent of the annual sediment influx to the Chesapeake Bay. This would equate to $2.6 \times 10^{6}$ tons (Officer and others, 1984). These estimates suggest a relatively small proportion of sediment inputs in the bay are trapped by intertidal marshes, contrary to the commonly perceived role of marshes as depositional systems in estuaries.

The most comprehensive study aimed at developing a bay-wide sediment budget is by Hobbs and others $(1990 ; 1992)$ (table 7.1). Building on the work of Ryan (1953), Biggs (1970), and Schubel and Carter (1976), Hobbs and others (1990; 1992) compiled data from parallel studies in Maryland (Kerhin and others, 1983, 1988) and Virginia (Carron, 1979; Byrne and others, 1982; Hobbs, 1983) and produced maps and tables that quantified net erosion and deposition of sediment throughout the bay. Unlike many other studies based on data from a longitudinal transect, or from a limited study area, this work produced a baywide sediment budget based on 3-dimensional data.

The approach of Hobbs and others (1990; 1992) was to determine sediment erosion and deposition by comparing U.S. Coast and Geodetic Survey hydrographic surveys carried out in the 1840s with more recent surveys made during the 1950s. Using the bathymetric differences between the two surveys, total accumulation and erosion of sediment was calculated in terms of volume and converted to mass (metric tons). The sediment budget of Hobbs and others (1990; 1992) (table 7.1) provides an excellent summary of average sediment accumulation and erosion over an approximately 100 -year period. Some of the most important conclusions from their reports include:

- Between the 1840s and 1950s, net deposition in Chesapeake Bay was between 1,049 and 2,915 million metric tons.

- This total exceeds the sum of quantifiable sources by 2.7 to 7.6 times, most of which is accounted for by ocean-source sands in the southern part of the bay; the budget for input and deposition of muds is balanced within a factor of 2.4.

- The Susquehanna River is a major source of fine-grained sediment to the upper bay. 
Table 7.1. Sediment budget data (modified from Hobbs and others, 1990)

[error, 95-percent confidence for predicted value; --, no data available]

\begin{tabular}{|c|c|c|c|c|c|c|}
\hline \multicolumn{7}{|c|}{ Deposition in Maryland portion of the Chesapeake Bay, in millions of metric tons in 100 year period } \\
\hline & Total & Organic & Inorganic & Sand & Silt & Clay \\
\hline Deposition & 822.15 & 16.98 & 805.18 & 524.13 & 121.61 & 159.46 \\
\hline Erosion & 661.11 & 10.62 & 650.49 & 469.46 & 69.9 & 111.13 \\
\hline Net & 161.04 & 6.35 & 154.69 & 54.67 & 51.71 & 48.33 \\
\hline \multicolumn{7}{|c|}{ Mass of silt/clay deposited in Maryland portion of Chesapeake Bay (summary from different studies) } \\
\hline Biggs (1970) & 83.8 & \multicolumn{5}{|c|}{ million metric tons/century } \\
\hline Schubel and Carter (1976) & 141 & \multicolumn{5}{|c|}{ million metric tons/century } \\
\hline Kerhin and others (1988) (total) & 281 & \multicolumn{5}{|c|}{ million metric tons/century } \\
\hline Kerhin and others (1988) (net) & 100 & \multicolumn{5}{|c|}{ million metric tons/century } \\
\hline \multicolumn{7}{|c|}{ Deposition in Virginia portion of the Chesapeake Bay, in millions of metric tons in 100 -year period } \\
\hline & \multicolumn{2}{|c|}{ Value } & \multicolumn{2}{|c|}{$\underline{\text { Standard Deviation }}$} & \multicolumn{2}{|c|}{ Error } \\
\hline Sand & \multicolumn{2}{|c|}{$2,210.4$} & \multicolumn{2}{|c|}{$1,690.7$} & \multicolumn{2}{|c|}{716.8} \\
\hline Silt & \multicolumn{2}{|c|}{329.6} & \multicolumn{2}{|c|}{305.9} & \multicolumn{2}{|c|}{110.2} \\
\hline Clay & \multicolumn{2}{|c|}{220.5} & \multicolumn{2}{|c|}{184.1} & \multicolumn{2}{|c|}{68.2} \\
\hline Total & \multicolumn{2}{|c|}{$2,760.8$} & \multicolumn{2}{|c|}{$2,180.8$} & \multicolumn{2}{|c|}{895.2} \\
\hline \multicolumn{7}{|c|}{ Sedimentation in Chesapeake Bay, in millions of metric tons per 100 -year period } \\
\hline$\underline{\text { Sources }}$ & \multicolumn{2}{|c|}{$\underline{\text { Sand }}$} & \multicolumn{2}{|c|}{$\underline{\text { Mud }}$} & \multicolumn{2}{|c|}{$\underline{\text { Total }}$} \\
\hline Shoreline erosion, Maryland & \multicolumn{2}{|c|}{74.0} & \multicolumn{2}{|c|}{137.0} & \multicolumn{2}{|c|}{211.0} \\
\hline Susquehanna River suspended sediment & \multicolumn{2}{|c|}{--} & \multicolumn{2}{|c|}{107.0} & & \\
\hline Shoreline erosion, Virginia & & & 2. & & & \\
\hline Biogenic silica, Virginia & & 8 & -- & & & \\
\hline Oceanic suspended sediment & & & 22. & & & \\
\hline Total & & & 268 & & & \\
\hline Deposition & & & Standard & viation & & \\
\hline Sand & & & 1,745 . & & & \\
\hline Silt & & & 357. & & & \\
\hline Clay & & & 232. & & & \\
\hline Total & 2,9 & & 2,335 . & & & \\
\hline
\end{tabular}

- The proximal continental shelf provides a large quantity of sand and suspended sediment (perhaps 40 percent of the net sediment deposition in the bay).

- Fine-grained ocean-source sediments might reach the mid-bay, which is farther north than previously thought to be deposited.

As part of the National Estuary Sediment Contaminant Inventory (NESCI), Nichols and others (1991) summarized sediment features for all the major tributaries of the bay. Although not explicitly a sediment budget study, the compilation by Nichols provides a useful review of the literature including data on sediment texture, sources, mass balance, and storage efficiency (proportion of riverine input stored) in each tributary in the Chesapeake system. The conclusions reached by Nichols and others include:

- Shoreline erosion contributes proportionally more sediment in tributaries with low riverine input.

- Shoreline erosion is more significant seaward in wider reaches of the bay because of exposure to wave action.

- Following erosion, winnowing and resuspension processes sort fine and coarse sediment; fine sediment ultimately settles further toward the channel because of slower settling rates and tidal currents. 
- Estuarine density-driven circulation influences the fate of fine-grained sediment once it has entered the main stem bay system; the upper estuarine layers generally transport sediment southward, and the lower layers transport sediment northward.

In addition to bay-wide sediment budgets, regional studies integrating bay tributaries with their watershed provide important linkages between the aquatic system and adjacent land areas that are useful for land-use management. One example is a recent study of the York River and its watershed (Herman, 2001). A series of sediment budgets were constructed for 11 nested subwatersheds ranging in size from 65 to $6,900 \mathrm{~km}^{2}$ in the Piedmont and Coastal Plain of Virginia. These watersheds extended from the headwaters to the estuary mouth and were used to examine sediment allocation as a function of watershed size. Data spanning decadal time scales and loads were calculated on an average annual basis. The results from Herman (2001) showed that in these lowrelief watersheds, sediment budgets are more influenced by the river system (Mattaponi and Pamunkey tributaries of the York River) than by sub-watershed size. Upland erosion was the major source of sediment in the Pamunkey River; bank erosion (including "shorelines" in the uppermost tidal zone) was the major source in the Mattaponi River. Upland storage was the major sink for both tributaries.

The York River study also indicated that little sediment from the upper watershed reached the estuary, indicating the Piedmont and Coastal Plain portions are "decoupled." Decoupling defines a process where a significant portion of sediment eroded from the upper or middle reaches of a basin is stored upstream and is not transported to the lower reaches of the basin. This results in increased streamflow energy and more sediment being mobilized and transported from downstream areas of the basin. As a result, management actions designed to decrease upland erosion and the implementation of buffers along streams to minimize the remobilization of colluvial storage may have limited effects farther downstream. Therefore, the improvement of water quality in the York River estuary may be largely independent of soilconservation practices implemented extended distances upstream. Water quality may be more affected by locally derived sediments near the estuary. The net movement of sediment at the mouth of the river is from the bay into the estuary. This, in combination with sediment movement during extreme storm events, implies that sediment management strategies in the York River watershed may also benefit from a regional focus.

Data from other studies provides additional information on sediment flux to the bay from the tributaries and within the bay. Information that was compiled on sediment sources and budgets from several studies is shown in figure 7.2. The data are reported in terms of contributions of sediment from rivers, shoreline erosion, oceanic sources, tributaries, and in-situ biogenic production in metric tons per year. These data also are given in volumetric and relative percent contributions in table 7.2. Other studies containing sediment-budget information not included in this summary are available for the Potomac River by Miller (1983) and Bennett (1983), the Rappahannock River by Lukin (1983), the Choptank River by Yarbro and others (1983), the Anacostia by Scatena (1987), and the South River by Marcus and others (1993) and Marcus and Kearney (1989; 1991). The following is shown in figure 7.2:

- Susquehanna River sediment dominates in the north.

- Oceanic-source sediment is the dominant sources in the southern bay, although this total includes an unknown amount of sediment eroded from shorelines and perhaps some sediment exported from major rivers. A further breakdown of this large flux of sediment requires more detailed analysis.

- Different tributaries have different relative contributions from riverine, shoreline, biogenic, and oceanic sources. Many studies did not include biogenic sediment and it is likely that biogenic material contributes substantial amount to particulate material in some regions.

- In different parts of large tributaries such as the Potomac, the relative proportion of shoreline and riverine sediments vary in upstream and downstream regions. This reflects the trapping of riverine sediments upstream and the diminished influence of riverine sources bay-ward down a major tributary. 
SOURCES OF SILT/CLAY SEDIMENT LOADS

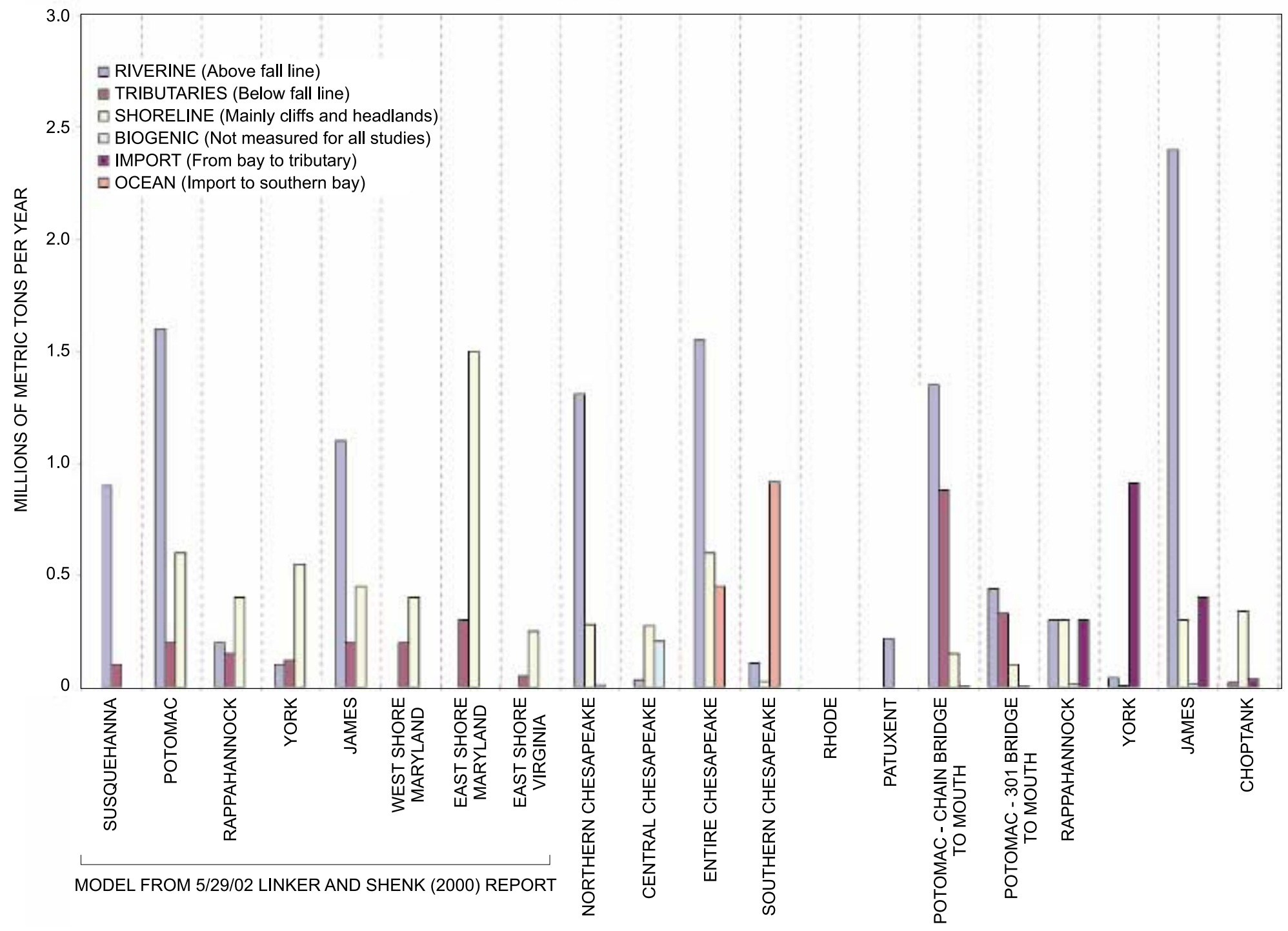

Figure 7.2. Fine-grained sediment sources from different sources based on literature (right half) compared to model-generated loads (left half). (Based on table 7.2 in Chapter 7.) 
Table 7.2. Suspended sediment source loads in the Chesapeake Bay estuary and its sub-estuaries. Values are in million metric tons per year (MT/yr) [Shaded areas represent model estimates; NC, not considered; --, no data; CB, Chesapeake Bay; mth, mouth; N/A, not applicable]

\begin{tabular}{|c|c|c|c|c|c|c|c|c|c|}
\hline Estuary & $\begin{array}{l}\text { Riverine } \\
\text { (above } \\
\text { Fall Line) }\end{array}$ & $\begin{array}{l}\text { Shoreline } \\
\text { (mainly } \\
\text { cliffs and } \\
\text { headlands) }\end{array}$ & $\begin{array}{l}\text { Biogenic } \\
\text { (not } \\
\text { measured } \\
\text { for all } \\
\text { studies) }\end{array}$ & $\begin{array}{l}\text { Import } \\
\text { (from } \\
\text { Bay to } \\
\text { tributary) }\end{array}$ & $\begin{array}{l}\text { Ocean } \\
\text { (import to } \\
\text { southern } \\
\text { bay) }\end{array}$ & $\begin{array}{l}\text { Tributaries }{ }^{1} \\
\text { (below fall } \\
\text { line) }\end{array}$ & Sum & Method & Citation \\
\hline Susquehanna & 900,000 & NC & NC & NC & NC & 100,000 & $1,000,000$ & Chesapeake Bay Program Model output & \multirow{8}{*}{$\begin{array}{l}\text { (Lewis Linker, personal communica- } \\
\text { tion, Watershed Model Phase } 4.3 \\
\text { Sediment load results, 2000 } \\
\text { Progress Scenario, 2003) }\end{array}$} \\
\hline Potomac & $1,600,000$ & 600,000 & NC & NC & NC & 200,000 & $2,400,000$ & Chesapeake Bay Program Model output & \\
\hline Rappahannock & 200,000 & 400,000 & NC & NC & NC & 150,000 & 750,000 & Chesapeake Bay Program Model output & \\
\hline York & 100,000 & 550,000 & NC & NC & NC & 120,000 & 770,000 & Chesapeake Bay Program Model output & \\
\hline James & $1,100,000$ & 450,000 & NC & NC & NC & 200,000 & $1,750,000$ & Chesapeake Bay Program Model output & \\
\hline West Shore Maryland & NC & 400,000 & NC & NC & NC & 200,000 & 600,000 & Chesapeake Bay Program Model output & \\
\hline East Shore Maryland & NC & $1,500,000$ & NC & NC & NC & 300,000 & $1,800,000$ & Chesapeake Bay Program Model output & \\
\hline East Shore Virginia & NC & 250,000 & NC & NC & NC & 50,000 & 300,000 & Chesapeake Bay Program Model output & \\
\hline North Chesapeake & $1,310,000$ & 280,000 & 10,000 & NC & NC & NC & $1,600,000$ & $\begin{array}{l}\text { Compiled from USGS gauge data, Kerhin and } \\
\text { others, 1988; Biggs, } 1970 .\end{array}$ & Halka (2000) \\
\hline Central Chesapeake & 33,000 & 275,000 & 206,000 & NC & NC & NC & 514,000 & $\begin{array}{l}\text { Bi-weekly sampling across } 5 \text { lateral upper bay } \\
\text { transects and } 6 \text { deep channel sites from Feb. } \\
\text { 1966-Jan. } 1967 .\end{array}$ & Biggs (1970) \\
\hline Chesapeake $^{2}$ & $1,550,000$ & 600,000 & NC & NC & 450000 & NC & $2,550,000$ & $\begin{array}{l}\text { Compiled from Byrne and Anderson, 1977; Hobbs } \\
\text { and others, 1990; Officer and others, 1984; } \\
\text { Schubel and Carter, } 1976 .\end{array}$ & Nichols and others (1991) \\
\hline South Chesapeake ${ }^{3}$ & 107,000 & 25,400 & 0 & NC & 1138400 & NC & $1,270,800$ & $\begin{array}{l}\text { Complied from Schubel and Carter, 1976; Kerhin } \\
\text { and others, 1983; Byrne and others, 1982; Singe- } \\
\text { wald and Slaughter, 1949; Byrne and Anderson, } \\
1977 .\end{array}$ & Hobbs and others (1990) \\
\hline South Chesapeake ${ }^{4}$ & NC & 423,000 & 12,520 & NC & -- & NC & 435,520 & $\begin{array}{l}\text { Complied from } 2000 \text { grab samples, Byrne and } \\
\text { Anderson, 1977; Jacobs and Grant, } 1978 .\end{array}$ & Byrne and others (1982) \\
\hline Rhode $^{5}$ & NC & NC & NC & NC & NC & 222 & 222 & $\begin{array}{l}\text { Gravimetric suspended sediment analysis of up to } \\
11 \text { tributaries from Jan. } 1974 \text { to Nov. } 1976 \text {. }\end{array}$ & Pierce and Dulong (1977) \\
\hline Patuxent ${ }^{6}$ & 216,000 & NC & NC & NC & NC & 49 & 216,049 & $\begin{array}{l}55 \text { mid-depth suspended sed. samples at seasonal } \\
\text { and characteristic intervals }\end{array}$ & Roberts and Pierce $(1974 ; 1976)$ \\
\hline $\begin{array}{l}\text { Potomac-Chain } \\
\text { Bridge to mouth } \\
\text { (historical) }\end{array}$ & $1,350,000$ & $\begin{array}{r}150,000 \\
(230,000)\end{array}$ & NC & 10,000 & NC & 880,000 & $2,390,000$ & $\begin{array}{l}\text { Comparison of shoreline maps and aerial photo- } \\
\text { graphs. }\end{array}$ & Miller (1987); Bennett (1983) \\
\hline $\begin{array}{l}\text { Potomac-301 } \\
\text { Bridge to mouth } \\
\text { (historical) }\end{array}$ & 440,000 & $\begin{array}{r}100,000 \\
(170,000)\end{array}$ & NC & 10,000 & NC & 330,000 & 880,000 & $\begin{array}{l}\text { Comparison of shoreline maps and aerial photo- } \\
\text { graphs. }\end{array}$ & Miller (1987); Bennett (1983) \\
\hline Rappahannock $^{7}$ & 300,000 & 300,000 & 15,000 & 300,000 & NC & NC & 915,000 & $\begin{array}{l}\text { Compiled from Hardaway and others, 1992; Nichols, } \\
\text { 1977; Schubel and Carter, 1976; Officer and } \\
\text { Nichols, 1980; Haven and others, } 1981 .\end{array}$ & Nichols and others (1991) \\
\hline York & 42,200 & 6,950 & NC & 910,000 & $\mathrm{NC}$ & NC & 959,150 & Quantified 11 sediment budgets. & Herman (2001) \\
\hline James $^{7}$ & $2,400,000$ & 300,000 & 15,000 & 400,000 & NC & NC & $3,115,000$ & $\begin{array}{l}\text { Compiled from Haven and others, } 1981 \text {; Nichols and } \\
\text { others, } 1991 .\end{array}$ & Nichols and others (1991) \\
\hline Choptank $^{8}$ & $-80,000$ & 340000 & NC & 36,000 & NC & 20,300 & 316,300 & $\begin{array}{l}\text { Monthly longitudinal cruises from Sep 1979-Aug. } \\
1980 .\end{array}$ & Yarbro and others $(1981 ; 1983)$ \\
\hline
\end{tabular}




\begin{tabular}{|c|c|c|c|c|c|c|c|c|c|}
\hline Estuary & $\begin{array}{l}\text { Riverine } \\
\text { (above } \\
\text { Fall Line) }\end{array}$ & $\begin{array}{l}\text { Shoreline } \\
\text { (mainly } \\
\text { cliffs and } \\
\text { headlands) }\end{array}$ & $\begin{array}{l}\text { Biogenic } \\
\text { (not } \\
\text { measured } \\
\text { for all } \\
\text { studies) }\end{array}$ & $\begin{array}{l}\text { Import } \\
\text { (from } \\
\text { Bay to } \\
\text { tributary) }\end{array}$ & $\begin{array}{l}\text { Ocean } \\
\text { (import to } \\
\text { southern } \\
\text { bay) }\end{array}$ & $\begin{array}{l}\text { Tributaries }{ }^{1} \\
\text { (below fall } \\
\text { line) }\end{array}$ & Sum & Method & Citation \\
\hline \multicolumn{10}{|c|}{ PERCENTAGES BY SEGMENT } \\
\hline Susquehanna & 90.00 & NC & NC & NC & NC & 10.00 & 100.00 & & \\
\hline Potomac & 66.67 & 25.00 & NC & NC & NC & 8.33 & 100.00 & & \\
\hline Rappahannock & 26.67 & 53.33 & NC & NC & NC & 20.00 & 100.00 & & \\
\hline York & 12.99 & 71.43 & NC & NC & NC & 15.58 & 100.00 & & \\
\hline James & 62.86 & 25.71 & NC & NC & NC & 11.43 & 100.00 & & \\
\hline West Shore Maryland & $\mathrm{NC}$ & 66.67 & NC & NC & $\mathrm{NC}$ & 33.33 & 100.00 & & \\
\hline East Shore Maryland & $\mathrm{NC}$ & 83.33 & NC & NC & NC & 16.67 & 100.00 & & \\
\hline East Shore Virginia & $\mathrm{NC}$ & 83.33 & NC & NC & NC & 16.67 & 100.00 & & \\
\hline North Chesapeake & 81.88 & 17.50 & 0.63 & NC & $\mathrm{NC}$ & $\mathrm{NC}$ & 100.00 & & \\
\hline Central Chesapeake & 6.42 & 53.50 & 40.08 & NC & NC & NC & 100.00 & & \\
\hline Chesapeake & 60.78 & 23.53 & NC & NC & 15.69 & NC & 100.00 & & \\
\hline South Chesapeake & 8.42 & 2.00 & 0.00 & NC & 89.58 & NC & 100.00 & & \\
\hline South Chesapeake ${ }^{4}$ & $\mathrm{NC}$ & 97.13 & 2.87 & NC & $?$ & NC & 100.00 & & \\
\hline Rhode & $\mathrm{NC}$ & NC & NC & NC & $\mathrm{NC}$ & 100.00 & 100.00 & & \\
\hline Patuxent & 99.98 & NC & NC & NC & $\mathrm{NC}$ & .02 & 100.00 & & \\
\hline Potomac-CB-mth & $56.4(54.6)$ & $6.3(9.3)$ & NC & $.5(.5)$ & NC & $36.8(35.6)$ & 100.00 & & \\
\hline Potomac-Rt. 301-mth & $50.0(46.3)$ & $11.4(17.9)$ & NC & $1.2(1.1)$ & $\mathrm{NC}$ & $37.5(34.7)$ & 100.00 & & \\
\hline Rappahannock & 32.79 & 32.79 & 1.64 & 32.79 & $\mathrm{NC}$ & NC & 100.00 & & \\
\hline York & 4.40 & 0.72 & NC & 94.88 & NC & NC & 100.00 & & \\
\hline James & 77.05 & 9.63 & 0.48 & 12.84 & $\mathrm{NC}$ & NC & 100.00 & & \\
\hline Choptank & $\mathrm{N} / \mathrm{A}$ & 85.79 & NC & 9.08 & $\mathrm{NC}$ & 5.12 & 100.00 & & \\
\hline
\end{tabular}

${ }^{1}$ Miller's study in the Potomac excluded sand.

2 Only examined fine sediment, discusses biogenic sources but did not quantify.

${ }^{3}$ Riverine values are mud, $1138400 \mathrm{Mt} / \mathrm{y}$ ocean value is based on $220000 \mathrm{Mt} / \mathrm{y}+918400 \mathrm{Mt} / \mathrm{y}$ based on Hobbs statement that 86 percent of $656000000 \mathrm{Mt} / \mathrm{y}$ is sand.

${ }^{4}$ Shoreline value is approximately 90 percent sand and is probably a conservative figure, ocean value represents sand. Byrne data not plotted in figure.

5 Transport represents 1976 value.

${ }^{6}$ Total sediment input values are given, but are primarily riverine.

${ }^{7}$ Biogenic input published as $<2.00 \mathrm{E}+04$, and estimated at $1.5 \mathrm{E}+04$, import value ignores resuspension.

${ }^{8}$ Negative value indicates a net export of riverine sediment, primary production not directly measure, but incorporated using average of total suspended material.

Average calculated where range was given (Chesapeake/Biggs-Riverine, Rappahannock/Nichols-Import, York/Herman Shoreline). 
- Shoreline sources of sediment are numerically important in the Choptank and Rappahannock tributaries, and to a lesser extent in the Potomac River.

In summary, there are enormous scientific and technical challenges to constructing a realistic, quantitative sediment budget for the bay. The large area covered by the bay and its watershed makes the development of a bay-wide sediment budget a difficult undertaking with any method. Although some integrated sediment-flux studies of smaller tributaries and their watersheds resulted in sediment budget estimates, these results cannot necessarily be extrapolated elsewhere in the bay because sediment sources and processes are spatially extremely variable.

A sediment budget also is ultimately dependent on the time scale chosen. If a short time scale is chosen, such as a single year, the complex temporal aspects of sedimentation, such as the unknown lag time from initial land-surface erosion until final deposition cannot be taken into account. Extreme episodic events that are of great importance in sediment transport and deposition also would be neglected. Conversely, a long-term sediment budget computing sediment flux over the 8,000-year history of the bay may give realistic estimates of net sediment accumulation over millennia, but this would probably be of little use to managers concerned with improving bay water quality.

Nonetheless, the literature provides a wealth of quantitative data on sediment flux from certain areas that could be of significant use in management efforts. A potential future need is an integrated study involving sedimentologists, hydrologists, and modelers to determine ways to apply the available data, to fill spatial gaps in the data, and to validate bay sediment models against empirical data.

\section{Model-Derived Sediment Estimates}

Various modeling approaches have been used to understand and predict sediment flux in the Chesapeake Bay system-the Spatially Referenced Regression Model (SPARROW) for suspended sediment, the Chesapeake Bay Watershed Model (WSM), and the Chesapeake Bay WaterQuality Model (WQM).

\section{Spatially Referenced Regression Model (SPARROW) for Sediment}

The SPARROW model is an effort to empirically address the question of sediment fate and transport on a national scale (G. Schwarz, U.S. Geological Survey, oral commun., 2002). The SPARROW model was first used to estimate the distribution of nutrients in streams and rivers of the United States and has subsequently been used to describe land and stream processes affecting the delivery of nutrients (Smith and others, 1997; Alexander and others, 2000; Preston and Brakebill, 1999). The model makes use of numerous spatial data sets, available at the national level, to explain long-term sediment water-quality conditions in major streams and rivers throughout the United States. The model described here is intended to empirically evaluate regional-scale processes affecting the long-term (decadal) transport of sediment in rivers.

Suspended sediment has long been recognized as an important factor affecting water resources. Besides its direct role in determining water clarity, bridge scour, and reservoir storage, sediment serves as a vehicle for the transport of many binding contaminants including nutrients, trace metals, semi-volatile organic compounds, and numerous pesticides (U.S. Environmental Protection Agency, 2000a). Recent efforts to address water-quality concerns through the Total Maximum Daily Load (TMDL) process have identified sediment as the single most prevalent cause of impairment in the Nation's streams and rivers (U.S. Environmental Protection Agency, 2000b).

A comprehensive understanding of sediment fate and transport is considered essential to the design and implementation of effective plans for sediment management (Osterkamp and others, 1998; U.S. General Accounting Office, 1990). Sediment sources are identified using sediment erosion rates from the National Resources Inventory (NRI) (Natural Resources Conservation Service, 2000) apportioned over the landscape according to $30-\mathrm{m}$ resolution land-use information from the National Land Cover Data set (NLCD) (U.S. Geological Survey, 2000). Over 76,000 reservoirs from the National Inventory of Dams (NID) (U.S. Army Corps of Engineers, 1996) are identified as potential sediment sinks. Other non-anthropogenic sources and sinks are identified using soil information from the State Soil Survey Geographic (STATSGO) database (Schwarz and Alexander, 
1995) and spatial coverages representing surficial rock type and vegetative cover. The SPARROW model empirically relates these diverse spatial datasets to estimates of long-term, mean annual sediment flux computed from concentration and flow measurements collected from 1985 to 1995 from more than 400 monitoring stations. These stations are maintained by National Stream Quality Accounting Network (NASQAN) (Alexander and others, 1998), the National Water Quality Assessment (NAWQA) Program, and U.S. Geological Survey District offices. The calibrated model is used to estimate sediment flux for over 60,000 stream segments included in the River Reach File 1 (RF1) stream network (Alexander and others, 1999).

An important implication of the SPARROW modeling approach adopted in this analysis is that estimates of sediment production and loss are based on measurements of in-stream flux. Other ancillary information, such as direct measurements of long-term sediment storage and release from reservoirs (Steffen, 1996) are incorporated into the analysis by specifying additional equations explaining these ancillary variables.

The mean annual suspended-sediment flux generated within and leaving a reach is referred to as the incremental reach flux. The flux consists of long-term sediment load data and several hypotheses of sediment fate and transport. The estimation of long-term suspended-sediment load at a monitoring station is based on the regression of the natural logarithm of instantaneous suspendedsediment concentration on current and lagged values of the natural logarithm of daily flow and other variables representing seasonal and trend effects. If the station has concentration data collected more frequently than on a weekly basis, the regression model is modified to account for serial correlation. To be included in the analysis, a station must have at least 3 years of data between 1985 and 1995.

The flexible mathematical structure of the model is capable of accommodating a number of hypotheses concerning sediment fate and transport. Sites of sediment storage can act as sediment sources or sinks. A random coefficient form of the model allows storage sites to serve as sources in some regions and sinks in others. Nonpoint sources of sediment, such as soil, are distinguished from sediment losses from storage (an alluvial plain) using the assumption that the former is a primary process of weathering whereas the latter is a consequence of the accumulation of previously weathered material later released to streams under changing hydraulic conditions. Accordingly, the potential for storage loss in the model depends on the extent of accumulated upstream soil erosion due to weathering. The empirical validity of the Universal Soil Loss Equation (USLE) estimate of soil erosion can be evaluated through statistical hypothesis tests of the relevant coefficients. Alternative measures of soil erosion also can be empirically evaluated in the model by substituting variables serving as determinants of the USLE for the USLE erosion estimate. Data on reservoir storage can be incorporated directly into the model by introducing an additional storage equation.

To complete the model structure, individual reaches are combined to form a nested basin. Each nested basin consists of reaches upstream from a given monitoring station and below any monitoring station further upstream (if such stations exist) (fig. 7.3).

Preliminary Results.-There are many impediments to understanding sediment storage because few stream and reservoir sites are monitored and it is difficult to know where and to what extent storage occurs in the basin-streambeds, floodplains, and (or) reservoirs for example. Based upon the previous discussion, a preliminary SPARROW model was constructed for suspended sediment in streams of the conterminous United States. The National model of sediment contains data from over 600 stations from USGS National Water-Quality monitoring networks, numerous GIS spatial coverage of causative factors including NRI, NLCD (National Land Cover Data-set), and STATSGO, and RF1 stream network with over 70,000 reservoirs from NID (National Inventory of Dams). The model structure is simple but flexible and contains a sufficient number of monitoring stations uniformly distributed nationally. The preliminary results show that the model agrees reasonably well with actual sediment data and coefficients (explanatory variables) are interpretable (G. Schwarz, U.S. Geological Survey, oral commun., 2002). Results also indicate that small streams, and not large streams, are sources of sediment, reservoirs are large sinks of sediment, the NRI provides an incomplete estimate of erosion, wind erosion reduces sediment susceptible to erosion to streams by runoff, surface-water runoff increases sediment erosion, and more permeable 


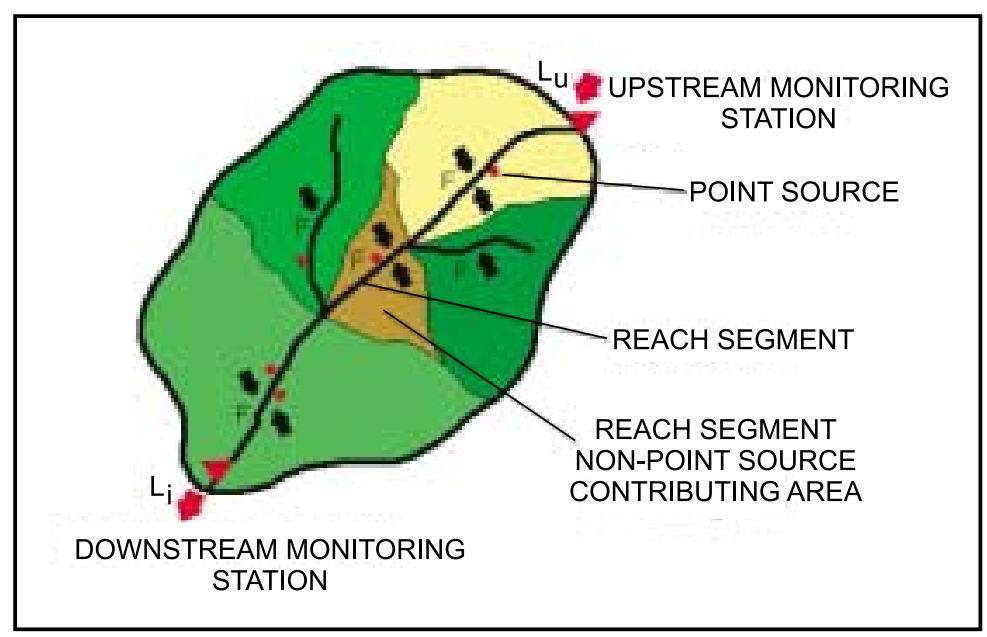

Figure 7.3. Schematic of a nested basin defined by upstream and downstream monitoring stations. ( $F$ is the total sediment flux generated within each nested basin, Lu is the upstream monitored load, and Li is the sum of F and Lu leaving the basin.) (Schwarz and others, 2001)

soils are less susceptible to erosion. Ideally, future model runs may include revised data sets and increased sediment data a-nd maps may be produced of delivered sediments loads and yields to "edge of field" (erosion from land) and "edge of stream" (erosion actually reaching the stream).

\section{Chesapeake Bay Watershed Model (WSM)}

The three cross-media models used for simulations of sediment in the Chesapeake Bay and watershed include the Regional Acid Deposition Model (RADM), the Watershed Model (WSM, Phase 4.3), and the Chesapeake Bay Estuary Model Package (CBEMP, which will be referred to as the Water Quality Model or WQM) (Linker and Shenk, 2000). The RADM is used to provide estimates of the deposition of air-borne nitrogen to the land and water surface and is not discussed in this report. Additional information about RADM can be obtained at the Web site http://www.epa.gov/ asmdner $/ \mathrm{radm} . \mathrm{html} /$. Simulation of suspended sediment and total suspended solids transport from the watershed to the estuary is performed using the WSM. The subsequent effects of suspended sol- ids on water clarity, SAV, and benthos are simulated using the WQM. In addition, the effects of benthos on suspended solids also are simulated.

The inputs of suspended sediment to the riverine system are calculated from each land unit in the WSM (below). Using a set of empirical equations, the detachment (erosion) of sediment from the soil matrix, movement of the eroded sediment in surface runoff, and scour of sediment are simulated to predict suspended-sediment concentration and load (Donigian and others, 1994).

There are two principal sources of eroded sediment in the WSM, raindrop detachment and agriculture tillage operations. Raindrop detachment includes variables for rainfall, energy, antecedent soil moisture, and percent of exposed soil. Raindrop detachment occurs throughout the year. Tillage operations from agricultural activities generate sediment from the turning of soil and other crop maintenance activities. Tillage operations generally occur once or twice a year, and an amount of detached sediment is treated as an instantaneous addition at time of tillage. Sediment storage is the amount of sediment eroded and

\begin{tabular}{|c|c|c|c|c|}
\hline \multicolumn{3}{|c|}{ Land Processes } & \multicolumn{2}{|c|}{ River Processes } \\
\hline $\begin{array}{l}\text { Erosion } \\
\text { rate }\end{array}$ & $\begin{array}{c}\text { Sediment } \\
\text { storage }\end{array}$ & $\begin{array}{l}\text { Transport } \\
\text { factors }\end{array}$ & $\begin{array}{l}\text { Deposition } \\
\text { and scour }\end{array}$ & $\begin{array}{c}\text { Suspended } \\
\text { sediment }\end{array}$ \\
\hline
\end{tabular}


available for transport. Sediment storage is calculated for each land use as a balance of sediment attachment and detachment and washoff. Washoff of detached sediment is a function of antecedent soil moisture and surface-water runoff. Parameters for attachment and detachment and washoff are selected to match calculations of annual soil erosion from crops, pasture, and forest lands based on National Resource Inventory (NRI) data applied to the USLE. Gross erosion rates are reduced by a delivery ratio to represent deposition loss (storage) on the land.

Simulation of suspended sediments in rivers is a mass balance of input, advection, scour, and deposition. Scour and deposition of silt and clay is simulated on an hourly basis by comparing the shear stress calculated by the hydrology module to a critical shear stress. Other parameters are erodibility, settling velocity, and bed storage. Separate parameters can be used for silt and clay. Sand concentration is simulated using a user-input power function of carrying capacity.

Calibration of sediment is a mass-balance approach where:

\section{Sediment mass balance $=$} land surface inputs + scour - deposition - advection downstream
Specifically, the calibration is obtained by (1) setting consistent detached sediment values from field operations on the basis of crop use, (2) calibration of sediment wash-off from all land uses on the basis of the NRI, and (3) calibration to observed sediment-concentration data at the water-quality monitoring sites and adjustment of scour and deposition parameters.

The RIM Program collects stream samples from the most downstream non-tidal areas in the eight largest basins (Susquehanna, Potomac, James, Patuxent, Rappahannock, York-2 basins, and Appomatox). In addition, one site, Choptank, is sampled on the eastern shore. Using hydrology data from 1985 to 1994, modeled total average annual suspended-solids loads from the WSM are approximately 4 million tons at the "Fall Line" River Input sites. This is in close agreement with the total average annual long-term monitoring programs estimated load. An additional 1.25 million tons are estimated by the WSM to be contributed from land areas (about 15 percent of the watershed) below the "Fall Line." The contribution and variability of the modeled loads above and below the Fall Line Zone are shown in figure 7.4. The three largest rivers (Susquehanna, Potomac, and James), which represent about 90 percent of the total land area above the Fall Line, contribute about 90 -percent of the average streamflow, and deliver the greatest amount of sediment to the estuary (Langland and others, 1995).

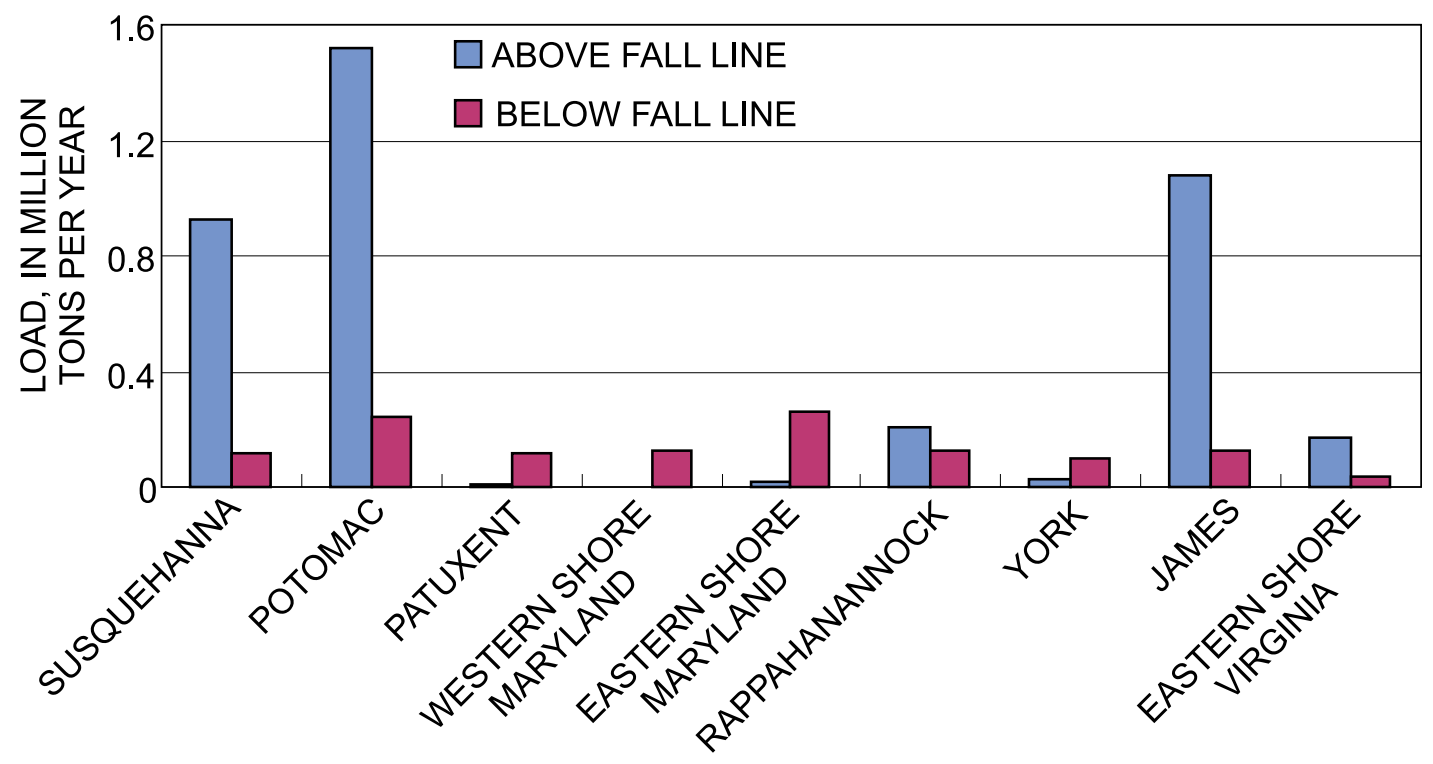

Figure 7.4. Modeled sediment-solids loads above and below the Fall Line. (From Chesapeake Bay Program Watershed Model v. 4.3.) 


\section{Chesapeake Bay Water Quality Model (WQM)}

The Chesapeake Bay WQM is a quantitative tool used to simulate the effects of the watershed and shoreline (or bank) contributions of suspended solids on water quality in the bay and its tributaries. The model is extremely complex. The model as it pertains to the sediment issues discussed throughout this report will be presented briefly below. The reader is encouraged to pursue additional details about the model, which can be found in Cerco and others (2002) and at the CBP Modeling Web site $h t t p: / / w w w . c h e s a p e a k e b a y . n e t / p u b s /$ subcommittee/mdsc.

Watershed sediment sources from above and below the Fall Line derived from the bay WSM are used as input for the WQM. Model simulations are carried out for all suspended sediment discharges at an hourly time step and then compiled into a daily average for all river loads input into the WQM. River input sediment loads estimated by the WQM at sites below the Fall Line are distributed to the lateral cells-areas in the bay near shorelines - on the basis of the relative watershed area associated with each of the lateral cells.

Empirical data compiled from various regions of the Chesapeake Bay are used to parameterize the WQM for estimates of suspended solids derived from shoreline erosion. Load estimates from shoreline sources are estimated as long-term averages expressed in volume or rate of mass per year on the basis of the volume of eroded material obtained from comparisons of topographic maps or aerial photographs that usually span several years. Information contained in a report by the USCOE (1990) and extensive measurements of the composition of eroded bank material for the major Virginia tributaries (Ibison and others, 1992) serve as primary sources of information on shoreline erosion (table 7.3)
Estimating bank loads for the model requires consideration of the volume of eroded material, the composition of the material, and the fraction of eroded material reaching the water column. The grain-size distribution of eroded material reaching the water column is an extremely important factor because sand and gravel sink rapidly and do not contribute to light attenuation (discussed in chapters 1, 5, and 6). Because of the high spatial variation in shoreline sediment sources and gaps in the database, bank erosion is considered in the model as a spatially and temporally uniform process. Loads to each surface cell are calculated as:

$$
\begin{gathered}
\text { Bank load }=\text { (Length) (erosion rate) } \\
\text { (fraction of silt/clay in total volume eroded) } \\
\text { (calibration factor to adjust bank loads) } \\
\text { (associated nutrient/carbon concentration) }
\end{gathered}
$$

A mean value for bank erosion of $11.4 \mathrm{~kg} \mathrm{~m}^{-1} \mathrm{~d}^{-1}$ is used. This total contains an estimated average of about 37-percent coarse material (sand and gravel); the remainder is finegrained material (table 7.3). Additional data from Maryland indicate average bank compositions of about 50-percent sand (Hill and others, 2001). The model-generated fine-grained solids estimate of $5.7 \mathrm{~kg} \mathrm{~m}^{-1} \mathrm{~d}^{-1}$ is a reasonable first approximation of mean fine-grained suspended load from shorelines (table 7.3).

Calibration of the WQM involves taking the WSM model daily sediment loads and using a constant daily input of shoreline erosion loads consistent with reported shoreline erosion rates. Sediment loads are removed by regional adjustment of settling rates to achieve observed solid concentrations in the water column consistent with the tidal program monitoring data.

Table 7.3. Composition of bank solids (from Ibison and others, 1992)

\begin{tabular}{lccccc}
\hline & $\begin{array}{c}\text { Gravel } \\
\text { (percent) }\end{array}$ & $\begin{array}{c}\text { Sand } \\
\text { (percent) }\end{array}$ & $\begin{array}{c}\text { Silt } \\
\text { (percent) }\end{array}$ & $\begin{array}{c}\text { Clay } \\
\text { (percent) }\end{array}$ & $\begin{array}{c}\text { Average of all } \\
\text { observations, } \\
\text { in kilograms per } \\
\text { meter per day }\end{array}$ \\
\hline Mean & 20.3 & 17.0 & 60.9 & 1.8 & 11.4 \\
Median & 16.3 & 16.3 & 63.1 & .1 & 8.55 \\
Standard deviation & 16.0 & 14.1 & 26.0 & .44 & 8.71 \\
Maximum & 71.9 & 60.3 & 98.7 & 5.31 & 32.7 \\
Minimum & .7 & .1 & 1.6 & 0 & .81 \\
Number of samples & 255 & 255 & 255 & 255 & 44 \\
Model & & & & & 5.7 \\
\hline
\end{tabular}


Two settling parameters are used in the model: a water column settling rate and a rate incorporating suspended sediments into the sediment layer. In some regions, such as the turbidity maximum and littoral zones, these settling rates are adjusted to reduce the amount of sediment entering the sediment layer, providing a method for the WQM to simulate re-suspension of fine particles.

Future research on sediment and water quality might include efforts to integrate the WQM efforts with field studies of sediment sources and grain size, with particular focus on spatial variability in shoreline loads.

The WQM also produces information showing the relative contribution to light attenuation from water color, algae and other organic material, and TSS (fig. 7.5). The inorganic component of light attenuation (suspended sediment) is dominant in nearly all bay segments (fig. 7.5). These types of data are useful for examining possible different sediment-reduction allocations and strategies. The spatial distribution of the model segments area are shown in figure 7.6. However, the components of attenuation alone do not determine the response to nutrient and solids-load reductions. Of paramount importance is the requirement by USEPA to bring total attenuation below levels that support SAV and meet waterclarity goals. A more useful classification of the Chesapeake Bay is to divide into regions subject to (1) nutrient control and (2) sediment-solids control (fig. 7.7). Regions subject to nutrient control are areas that meet living-resources criteria (Batiuk and others, 1992) and areas in which criteria can be met by reducing attenuation from organic matter. These correspond to areas in which attenuation from color and fixed solids is less than $2 \mathrm{~m}^{-1}$ for freshwater species and less than $1.5 \mathrm{~m}^{-1}$ for other species. Regions in which attenuation from color and sediment solids exceeds $1.5 \mathrm{~m}^{-1}$ (saltwater) to $2 \mathrm{~m}^{-1}$ (freshwater) will not support SAV absent reductions in fixed solids. This classification indicates SAV cannot be restored to large parts of the major tributaries solely via nutrient reduction. Restoration of SAV to the turbidity maximum of the main stem and to the headwaters of several minor tributaries also requires sediment-solids reductions (Cerco and others, 2002).

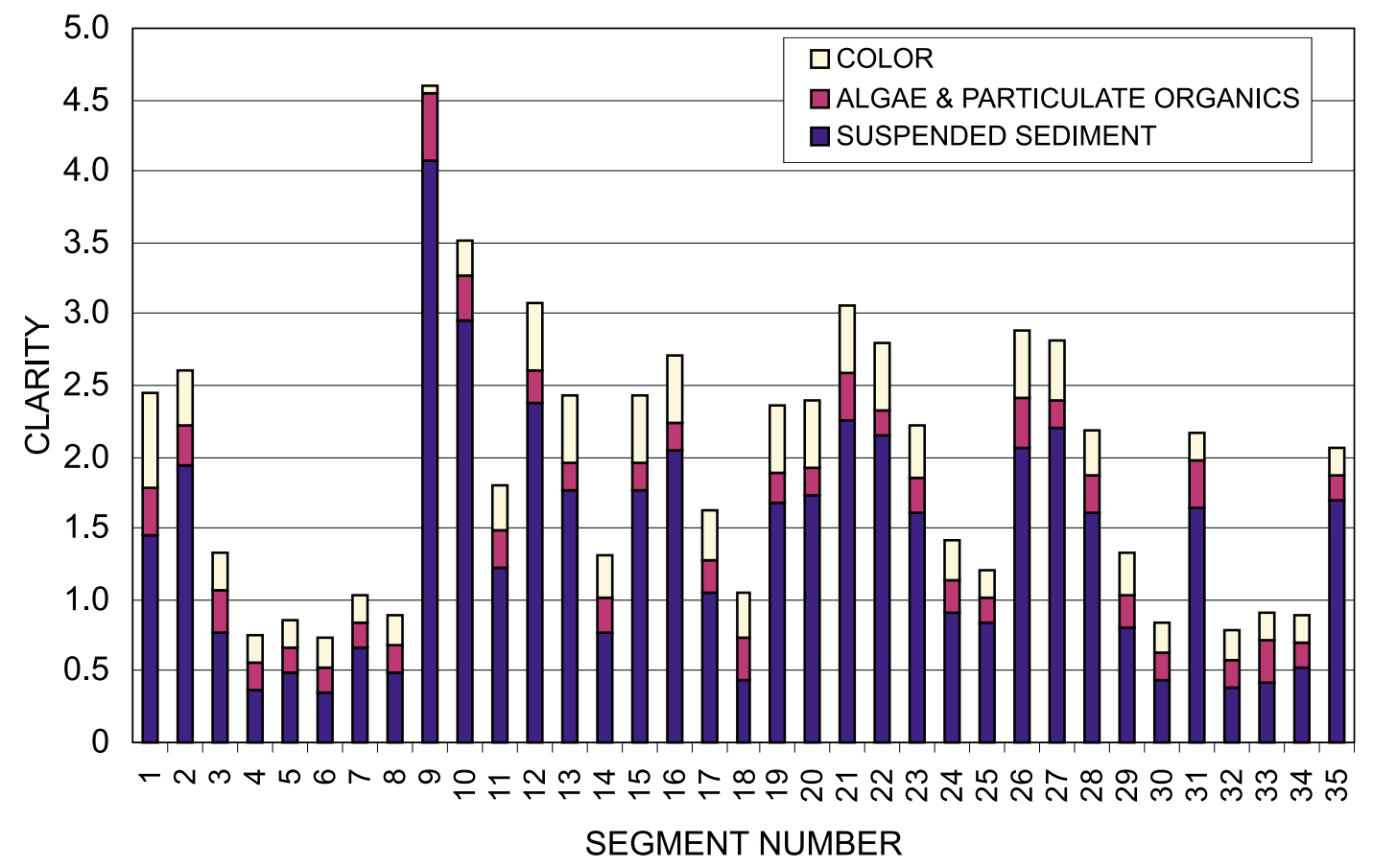

Figure 7.5. Relative proportion of light attenuation by component for major bay segments. (Segment locations shown on figure 7.6.) 


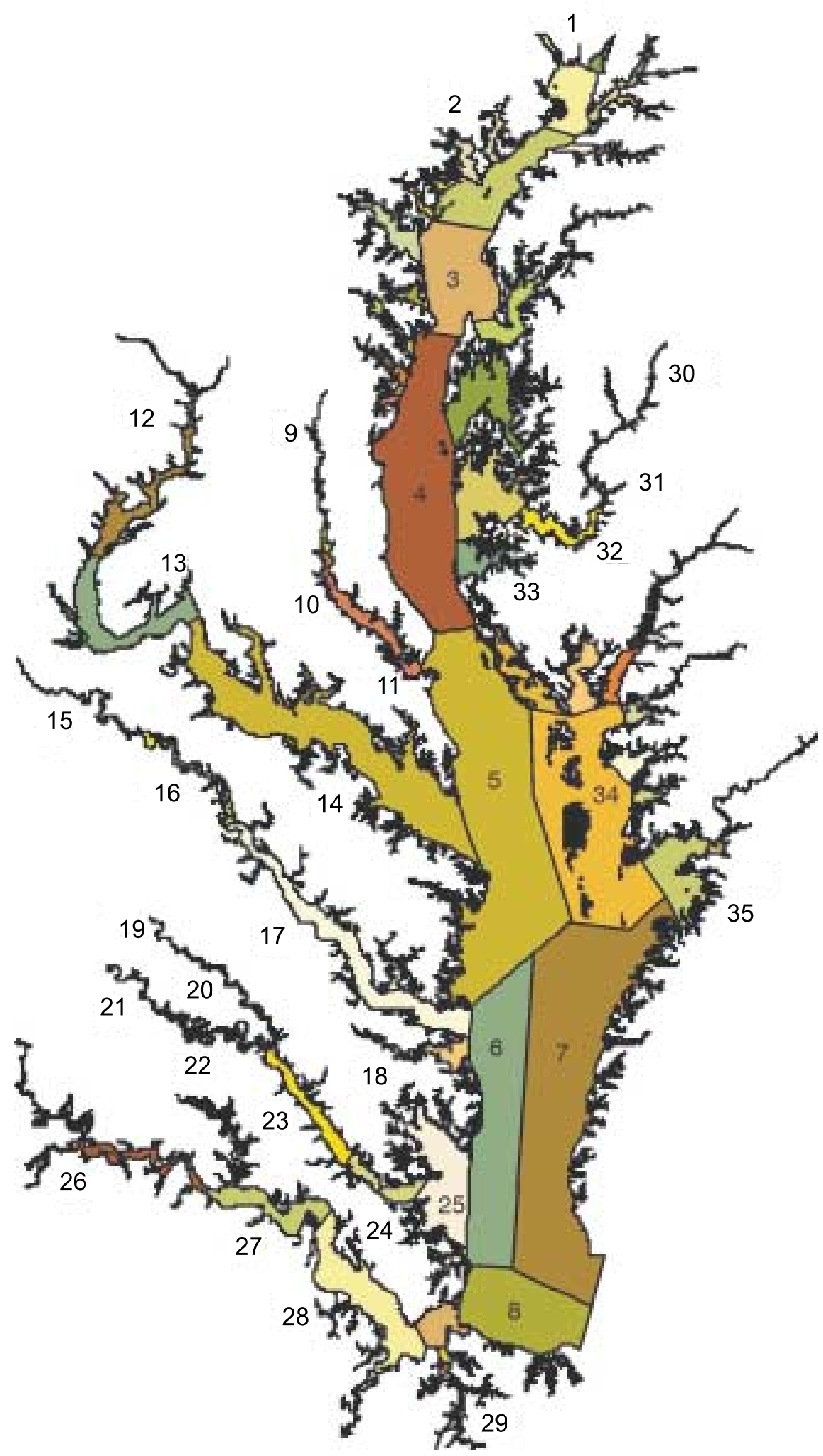

Figure 7.6. Location of estuary model segment number as used in the waterquality model (WQM). 


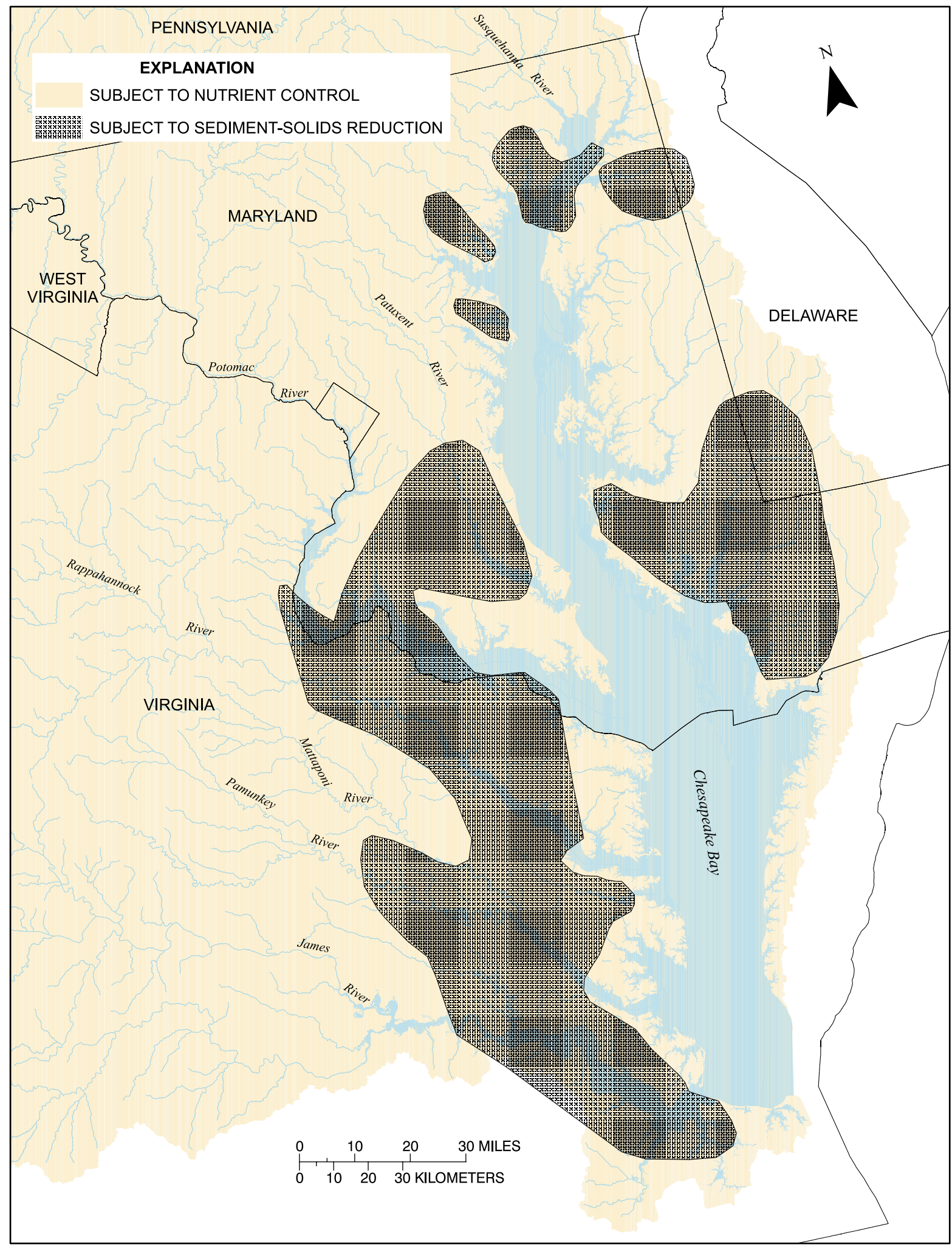

Figure 7.7. Estuarine areas that benefit more from sediment controls (shaded area) than from nutrient controls (areas shown in yellow) in the watershed and tidal tributaries (Cerco and others, 2002). 
However, as has been discussed throughout this report, the bay ecosystem involves very complex physical and chemical processes; therefore, addressing nutrient or sediment issues alone most likely will not meet the water-clarity goals by 2010 . In conclusion, because neither nutrient nor sediment is completely dominant in terms of light attenuation and resulting loss of water clarity, it may be necessary for water-resource managers to develop nutrient and sediment reduction strategies. These strategies will vary spatially and temporally on the basis of light attenuation factors and overall cost/benefit analysis.

\section{Sediment Reduction Controls (Best-Management Practices)}

The CBP WSM (version 4.3) simulates TSS reductions resulting from the implementation of best-management practices. The simulation methods for estimating TSS reductions include land-use conversions, application of best-managementpractice efficiencies, and a combination of land-use conversions and efficiencies (table 7.4).

Land-use conversion represents the conversion of one land use into another. Conversion of a land use with a high sediment-loading rate into a land use of lower sediment-loading rate is simulated as a reduction in sediment loads. An example of such a conversion would be planting riparian forest buffers on conventionally tilled agricultural land. In this example, the model simulates the reduction as the difference between the conventionally tilled land sediment-loading rate minus the forest loading times the number of acres converted. The difficulty with land-use conversion is that the model assumes the land-use conversion is immediate and complete. In the example of forest buffers, the model assumes the newly planted saplings immediately function as a mature forest

Table 7.4. Sediment reductions for various best-management practices simulated in the Watershed Model (L. Linker, U.S. Environmental Protection Agency, written commun., 2002)

\begin{tabular}{lcc}
\hline \multicolumn{1}{c}{ Best-management practice } & $\begin{array}{c}\text { Sediment } \\
\text { reduction } \\
\text { (percent) }\end{array}$ & Model use \\
\hline Wetland restoration (high-till) & 96 & Land-use conversion \\
Wetland restoration (low-till) & 84 & Land-use conversion \\
Wetland restoration (hay) & 80 & Land-use conversion \\
Tree planting (high-till) & 96 & Land-use conversion \\
Tree planting (low-till) & 84 & Land-use conversion \\
tree planting (pasture) & 82 & Land-use conversion \\
Land retirement (high-till) & 90 & Land-use conversion \\
Land retirement (low-till) & 61 & Land-use conversion \\
Land retirement (hay) & 53 & Land-use conversion \\
Forest conservation (pervious urban) & 76 & Land-use conversion \\
Streambank protection with fencing (pasture) & 75 & Efficiency \\
Conservation tillage (high-till) & 73 & Land-use conversion \\
Forest buffers (high-till, low-till, hay) & 70 & Land-use conversion \& efficiency \\
Stormwater management (pervious, impervious urban) & 65 & Efficiency \\
Tree planting (mixed open) & 58 & Land-use conversion \\
Grass buffers (high-till, low-till) & 53 & Land-use conversion \& efficiency \\
Erosion and sediment control (pervious, impervious urban) & 50 & Efficiency \\
Forest harvesting practices (forest) & 50 & Efficiency \\
Farm plans (high-till) & 40 & Efficiency \\
Farm plans (pasture) & 14 & Efficiency \\
Farm plans (low-till, hay) & 8 & Efficiency \\
Streambank protection without fencing (pasture) & 40 & Efficiency \\
Abandoned mine reclamation (exposed/urban) & 15 & Efficiency \\
Cover crops (high-till, low-till) & & Land-use conversion \\
\hline & & \\
& & \\
\end{tabular}


buffer. This results in the WSM model overestimating the sediment-load reductions of the forest buffer for the period it takes the buffer to reach maturity equal to that of resident forest. Additional data is needed to develop variable TSS efficiencies for land-use conversion accounting for the maturity of the conversion over time. For bestmanagement practices that mature quickly or are quickly functional, such as grass buffers and wetlands, there most likely would be minimal or inconsequential overestimation.

Application of best-management-practice percent efficiencies represents the second method utilized within the watershed model to simulate TSS reductions. These best-management practices reduce the TSS load by a set percentage of each acre treated or affected by the best-management practice. As an example, implementing a farm plan on conventional cropland is estimated to reduce TSS loads by 40 percent for each acre under the plan.

At the time best-management-practice efficiencies were developed, limited data were available on the effectiveness of best-management practices for reducing TSS loads. Consequently, the CBP decided to use an interim methodology for TSS reductions based on total phosphorus reductions. For nearly all best-management practices with TSS reduction efficiencies (except stormwater management), the TSS reduction efficiencies are set equivalent to the phosphorus reduction efficiency for the practice. This interim methodology is based on the premise that sediment movement and transport is the primary mechanism for phosphorus transport and that reduction in total phosphorus results in a similar reduction in sediment loss. Sediment load reductions also may be overestimated by not varying the efficiencies of bestmanagement practices for different storm events and accounting for design limitations, including design "lifetimes." The WSM assumes a constant reduction in sediment load for all flows, at all times. A reduction in efficiency usually results from higher flows and the capacity to store, treat, and hold sediment is lost over time.

The percent reduction efficiencies for total phosphorus are based on a variety of information sources depending on the particular best-management practice. These sources include scientific literature, performance data, local site-specific studies, and best professional judgment in some cases. At the time the efficiencies for the best-management practices were agreed upon by the CBP, it was acknowledged that new methodologies for estimating TSS reduction efficiencies should be evaluated. Additional data on sediment transport would be helpful to define separate TSS reduction efficiencies for those best-management practices that will be considered for implementation by water-resource managers to reach new sediment goals. 


\section{REFERENCES CITED}

Adelson, J.M., Helz, G.R., and Miller, C.V., 2001, Reconstructing the rise of recent coastal anoxia-molybdenum in Chesapeake Bay sediments: Geochemica et Cosmochemica Acta, v. 65, p. 237-252.

Alexander, R.B., Brakebill, J.W., Brew, R.E., and Smith, R.A., 1999, ERF1-Enhanced River Reach File 1.2: U.S. Geological Survey Open-File Report 99-457.

Alexander, R.B., Slack, J.R., Ludtke, A.S., Fitzgerald, K.K., and Schertz, T.L., 1998, Data from selected U.S. Geological Survey national stream water-quality monitoring networks: Water Resources Research, v. 34, no. 9, p. 2,401-2,405.

Alexander, R.B., Smith, R.A., and Schwarz, G.E., 2000, Effect of channel size on the delivery of nitrogen to the Gulf of Mexico: Nature, v. 403, p. 758-761.

Anderson, I.C., Miller, W.D., and Neubauer, S.C., 1977, The effects of wrack deposition and increased inundation frequency on production and respiration in a Spartina patens/Distichlis spicatai salt marsh: Virginia Coast Reserve Long Term Ecological Research All Scientists Meeting.

Baker, J.E., Mason, R., Cornwell, J., Ashley, J., Halka, J., Hill, J., Fisher, D., and McGee, B., 1997, Spatial Mapping of Contaminants in the Baltimore Harbor, Patapsco River/Back River System: University of Maryland, Center for Environmental and Estuarine Studies, UMCES [CBL], p. 97-142.

Baker, V.R., Kochel, R.C., and Patton, P.C., eds., 1988, Flood geomorphology: New York, John Wiley and Sons, $503 \mathrm{p}$.

Batiuk, R., Heasley, P., Orth, R., Moore, K., Stevenson, J.C., Dennison, W.S., Carter, V., Rybicki, N.B., Hickman, R.E., Kollar, S., and Bieber, S.B.P., 1992, Chesapeake Bay submerged aquatic vegetation habitat requirements and restoration goals-A technical synthesis: U.S. Environmental Protection Agency CBP/TRS 83/92.

Batiuk, R., Bergstrom, P., Kemp, M., Koch, E., Murray, L., Stevenson, J.C., Bartleson, R., Carter, V., Rybicki, N.B., Landwehr, J.M., Gallegos, C., Karrh, L., Naylor, M., Wilcox, D., Moore, K.A., Ailstock, S., and Teichberg, M., 2000, Chesapeake Bay submerged aquatic vegetation water quality and habitat-based requirements and restoration targets-A second technical synthesis: U.S. Environmental Protection Agency CBP/TRS 245/00.
Bazemore, D.E., Hupp, C.R., and Diehl, T.H., 1991, Wetland sedimentation and vegetation patterns near selected highway crossings in West Tennessee: U.S. Geological Survey WaterResources Investigations Report 91-4106, 46 p.

Bennett, J.P., 1983, Nutrient and sediment budgets for the tidal Potomac River and estuaryDissolved loads of rivers and surface water quantity/quality relationships: Proceedings of a symposium, XVIII General Assembly of the International Union of Geodesy and Geophysics, Hamburg, West Germany, IAHS Publication 141, p. 217-227.

Berquist, C.R., Jr., 1986, Stratigraphy and heavy mineral analysis in the Lower Chesapeake Bay, Virginia: PhD. dissertation, College of William and Mary, Gloucester Point, Va., p. 105.

Biedenharn, D.S., Copeland, R.R., Thorn, C.R., Soar, P.J., Hey, R.D., and Watson, C.C., 2000, Effective discharge calculation-A practical guide: U.S. Army Corps of Engineers, Coastal and Hydraulics Laboratory, ERDC/CHL-TR-00-15.

Biesecker, J.E., Lescinsky, J.B., and Wood, C.R., 1968, Water resources of the Schuylkill River Basin: Commonwealth of Pennsylvania, Department of Forests and Waters, Water Resources Bulletin, no. 3, 198 p.

Biggs, R.B., 1970, Sources and distribution of suspended sediment in northern Chesa-peake Bay: Marine Geology, v. 9, p. 187-201.

Boon, J.D., Green, M.O., and Suh, K.D., 1996, Bimodal wave spectra in lower Chesapeake Bay, sea bed energetics and sediment transport during winter storms: Continental Shelf Research, v. 16 , no. 15 , p. $1,965-1,988$.

Bratton, J.F., Colman, S.M., Seal, R., II, and Baucom, P.C., 2002, Isotopic record of nitrogen and carbon cycling in Chesapeake Bay over the last 2700 years and implication for modern oxygen depletion: Geochimica et Cosmochimica Acta, $61 \mathrm{p}$.

Brown, L., Pavich, M.J., Hickman, R.E., Klein, J., and Middleton, R., 1988, Erosion of the eastern United States observed with ${ }^{10} \mathrm{Be}$ : Earth surface processes and landforms, v. 13, p. 441457.

Brush, G.S., 1984, Patterns of recent sediment accumulation in Chesapeake Bay (Virginia, Maryland, USA) tributaries: Chemical Geology, v. 44, p. 227-242.

1989, Rates and patterns of estuarine sedimentation: Limnology and Oceanography, v. 34, p. 1,235-1,246.

Brush, G.S., and Davis, F.W., 1984, Stratigraphic evidence of human disturbance in an estuary: Quaternary Research, v. 22, p. 91-108. 


\section{REFERENCES CITED—CONTINUED}

Brush, G.S., and Hilgartner, W.B., 2000, Paleoecology of submerged macrophytes in the upper Chesapeake Bay: Ecological Monographs, v. 70, no. 4, p. 645-667.

Brush, G.S., Martin, E.A., DeFries, R.S., and Rice, C.A., 1982 , Comparisons of ${ }^{210} \mathrm{~Pb}$ and pollen methods for determining rates of estuarine sediment accumulation: Quaternary Research, v. 18 , no. 2 , p. $196-217$.

Byrne, R.J., and Anderson, G.L., 1977, Shoreline erosion in tidewater Virginia: SRAMSOE, no. 111, Virginia Institute of Marine Science, School of Marine Science, Gloucester Point, Va.

Byrne, R.J., Hobbs, C.H., and Carron, M.J., 1980, Baseline sediment studies to determine distribution, physical properties, sedimentation budgets and rates in the Virginia portion of the Chesapeake Bay: Environmental Protection Agency Report.

1982, Baseline sediment studies to determine distribution, physical properties, sedimentation budgets and rates in the Virginia portion of the Chesapeake Bay: Final Report to the U.S. Environmental Protection Agency, Gloucester Point, Va., Virginia Institute of Marine Sciences, 155 p.

Campbell, I.A., 1992, Spatial and temporal variations in erosion and sediment yield: Erosion and sediment transport monitoring programs in river basins, IAHS, no. 210, p. 455-465.

Caraco, D., 1995, Keeping soil in its place: Watershed Protection Techniques, v. 2, p. 418-423.

Carling, P., 1988, The concept of dominant discharge applied to two gravel bed streams in relation to channel stability thresholds: Earth Surface Processes and Landforms, v. 22, no. 3, p. 369379.

Carron, M.J., 1979, The Virginia Chesapeake BayRecent sedimentation and paleodrainage: unpublished dissertation, Virginia Institute of Marine Science, College of William and Mary, Gloucester Point, Va., 83 p.

Cerco, C.F., Johnson, B.H., and Wang, H.V., 2002, Tributary refinements to the Chesapeake Bay Model: Washington, D.C., U.S. Army Corps of Engineers, ERDC TR-02-4, 201 p.

Colman, S.M., Baucom, P.C., Bratton, J.F., Cronin, T.M., McGeein, J.P., Willard, D.A., Zimmerman, A.R., and Vogt, P.R., 2001, Radiocarbon dating, chronologic frame-work, and changes in accumulation rates of Holocene estuarine sediments from Chesapeake Bay: Quarternary Research, v. 57, p. 58-70.
Colman, S.M., Berquist, C.R., and Hobbs, C.H., III, 1988, Structure, age, and origin of the deposits beneath the shoals at the mouth of the Chesapeake Bay, Virginia: Marine Geology, v. 83 , p. $95-113$.

Colman, S.M., and Bratton, J.F., 2003, Anthropogenically induced changes in sediment and biogenic silica fluxes in Chesapeake Bay: Geology, v. 31, p. 71-74.

Colman, S.M., Halka, J.P., and Hobbs, C.H., III, 1992, Patterns and rates of sediment accumulation in the Chesapeake Bay during the Holocene rise in sea level, in Fletcher, Charles H., I., and Wehmiller, J.F., eds., Quaternary Coasts of the United States: Marine and Lacustrine Systems: Special Publication: Tulsa, OK, (SEPM) Society for Sedimentary Geology, p. 101-111.

Colman, S.M., Halka, J.P., Hobbs, C.H., III, Mixon, R.B., and Foster, D.S., 1990, Ancient channels of the Susquehanna River beneath Chesa-peake Bay and the Delmarva Peninsula: Geological Society of America Bulletin, v. 102, p. 12681279.

Colman, S.M., and Hobbs, C.H., III, 1987, Quaternary geology of the southern Virginia part of the Chesapeake Bay: U.S. Geological Survey Miscellaneous Field Studies Map MF-1948-A, 2 sheets.

Conkwright, R., 1975, Historical shorelines and erosion rate atlas: Maryland Geological Survey, Baltimore, Md.

Cooper, S.R., 1995, Chesapeake Bay watershed historical land use-Impact on water quality and diatom communities: Ecological Applications, v. 5, p. 703-723.

Cooper, S.R., and Brush, G.S., 1991, Long-term history of Chesapeake Bay anoxia: Science, v. 254, p. 992-996.

1993, A 2500 year history of anoxia and eutrophication in Chesapeake Bay: Estuaries, v. 16, no. 3b, p. 617-626.

Cooper, J.R., Gilliam, J.W., Daniels, R.B., and Robarge, W.B., 1987, Riparian areas as filters for agricultural sediment: Journal of the Soil Science Society of America, v. 51, p. 416-420.

Cornwell, J.C., Conley, D.J., Owens, M., and Stephenson, J.C., 1996, A sediment chronology of the eutrophication of Chesapeake Bay: Estuaries, v. 19, no. 2B, p. 488-499.

Costa, J.E., 1974, Response and recovery of a Piedmont watershed from tropical storm Agnes: Water Resources Research, v. 10, p. 106-112. 


\section{REFERENCES CITED—CONTINUED}

1975, Effects of agriculture on erosion and sedimentation in the Piedmont Province, Maryland: Geological Society of America Bulletin, v. 86, no. 9, p. 1,281-1,286.

Crane, R.G., and Hewiston, B.C., 1998, Doubled $\mathrm{CO}_{2}$ precipitation changes for the Susquehanna basin-Down-scaling from the genesis general circulation model: International Journal of Climatology, v. 18, p. 65-76.

Cronin, T.M., Dwyer, G.S., Kamiya, T., Schwede, S., and Willard, D.A., 2003, Medieval warm period, little ice age and 20th century temperature variability from Chesapeake Bay: Global and Planetary Change, v. 36, no. 12, p. 17-29.

Cronin, T.M., and Vann, C., 2003, The sedimentary record of anthropogenic and climatic influence on the Patuxent Estuary and Chesapeake Bay ecosystems: Estuaries, v. 26, no. 2A.

Cronin, T., Willard, D., Verardo, S., McGeehin, J., Karlsen, A., Kerhin, R., Holmes, C., Colman, S., and Zimmermann, S., 2000, Climatic variability in the eastern United States over the past millennium from the Chesapeake Bay sediments: Geology, v. 28, p. 3-6.

Cronin, W.B., 1971, Volumetric, areal, and tidal statistics of the Chesapeake Bay and its tributaries: The Chesapeake Bay Institute of the Johns Hopkins University, v. 20.

Cutshall, N.H., Larsen, I.L., and Nichols, M.M., 1981, Man-made radionuclides confirm rapid burial of kepone in James River sediment: Science, v. 213, p. 440-442.

Darby, D.A., 1990, Evidence for the Hudson River as the dominant source of sand on the U.S. Atlantic Shelf: Nature, v. 346, p. 828-831.

Davis, J., and Laird, B., 1976, The effects of tropical storm Agnes on Chesapeake Bay estuarine system: Chesapeake Research Consortium, Publication 54,643 p.

Defries, R.S., 1986, Effects of land-use history on sedimentation in the Potomac Estuary, Maryland: U.S. Geological Survey WaterSupply Paper 2234-K, p. K1-K23.

Dietrich, W.E., and Dunne, T., 1978, Sediment budget for a small catchment in mountainous terrain: Zeitschrift fur Geomorphologie, v. 29, p. 191-206.

Dietrich, W.E., Dunne, T., Humphrey, N.F., and Reid, L.M., 1980, Construction of sediment budgets for catchments: Proceedings from Workshop on Sediment Routing in Forested Catchments, ed., Swanson, F., Janda, R., and Dunne T., Northwest Experiment Station, Corvallis, Oregon, May 30-June 1.
Dillaha, T.A., and Inamdar, S.P., 1996, Buffer zones as sediment traps or sources: Buffer zones-Their processes and potential in water protection, in Haycock, N., Burt, T., Goulding, K., and Pinay G., eds., The Proceedings of the International Conference on Buffer Zones, Quest Environmental, Hertfordshire, UK, p. 33-42.

Donigian, A., Jr., Anthony, S., Bicknell, B., Patwardhan, A., Linker, L., Avinish, S., Chang, C., and Reynolds, R., 1994, Watershed model application to calculate bay nutrient loadingsFinal findings and recommendations: U.S. Environmental Protection Agency, Chesapeake Bay Program Office, Annapolis, Md.

Donoghue, J.F., 1990, Trends in Chesapeake Bay sedimentation rates during the Late Holocene: Quaternary Research, v. 34, p. 33-46.

Donoghue, J.F., Bricker, O.P., and Olsen, C.R., 1989, Particle-borne radionuclides and tracers for sediment in the Susquehanna River and Chesapeake Bay: Estuarine, Coastal and Shelf Science, v. 29, p.341-360.

Dreher, D., and Price, T., 1995, Application of urban targeting and prioritization methodo-logy to Butterfield Creek, Cook and Will Counties, Illinois: National Conference on Urban Runoff Management-Enhancing Urban Watershed Management at the Local, County, and State Level, EPA/625/R-95/003, p. 119-134.

Dunne, Thomas, and Leopold, L.B., 1978, Water in environmental planning: San Francisco, W.H. Freeman and Sons, Inc., $818 \mathrm{p}$.

Edwards, T.K., and Glysson, G.D., 1988, Field methods for measurement of fluvial sediment: U.S. Geological Survey Open-File Report 86-531, 118 p.

Ellison, R.L., and Nichols, M.M., 1976, Modern and Holocene foraminifera in the Chesapeake Bay region, in Schaefer, C.T., and Pelletier, B.R., eds., International Symposium on Benthonic Foraminifera of Continental Margins, Part A, Ecology and Biology: Halifax, Nova Scotia, Canada, Maritime Sediments Special Publication 1, p. 131-151.

Fisher, T.R., Harding, L.W., Jr., Stanley, D.J., and Ward, L.G., 1988, Phytoplankton, nutrients, and turbidity in the Chesapeake, Delaware, and Hudson Estuaries: Estuarine, Coastal, and Shelf Science, v. 27, p. 61-93.

FISRWG, 1998, Stream corridor restorationPrinciples, processes, and practices: GPO Item no. 0120-A, SuDocs no. A 57.6/2:EN 3/PT.653, ISBN-0-934213-59-3. 


\section{REFERENCES CITED-CONTINUED}

Fredericks, D.J., and Perrens, S.J., 1988, Estimating erosion using caesium-137: II-estimating rates of soil loss, in Bordas, M.P., and Walling, D.E., eds., Sediment budgets, IAHS Publication no. 174 , p. 233-240.

Fugate, D.C., and Friedrichs, C.T., 2002, Determining concentration and fall velocity of estuarine particle populations using ADV, OBS and LISST: Continental Shelf Research, v. 22, no. $11-13$, p. $1867-1886$.

Gao, S., and Collins, M.B., 1997, Changes in sediment transport rates caused by wave action and tidal flow time-asymmetry: Journal of Coastal Research, v. 13, no. 1, p. 198-201.

Garcia, M., 1999, Sedimentation and erosion hydraulics, in Mays, L.W., ed., Hydraulic design handbook: New York, McGraw Hill, Inc., chap. 6.

Gardner, W.D., Biscaye, P.E., Zaneveld, R.V., and Richardson, M.J., 1985, Calibration and comparison of the LDGO Nephelometer and the OSU Transmissometer on the Nova Scotian Rise: Marine Geology, v. 66, p. 323-344.

Gellis, A.C., Pavich, M.J., and Ellwein, A., 2001, Erosion and sediment yields in two subbasins of contrasting land use, Rio Puerco, New Mexico: Proceedings of the Seventh Federal Interagency Sedimentation Conference, Reno, Nevada, p. V83-V90.

Geyer, W.R., Woodruff, J.D., and Traykovski, P., 2001, Sediment transport and trapping in the Hudson River estuary: Estuaries, v. 24, no. 5, p. 670-679.

Gibson, J.R., and Najjar, R.G., 2000, The response of Chesapeake Bay salinity to climate induced changes in streamflow: Limnological Oceanography, v. 45 , no. 8, p. 1,764-1,772.

Goldberg, E.D., Hodge, Vern, Koide, Minoru, Griffin, John, Gamble, Eric, Bricker, O.P., Matisoff, Gerry, Holdren, G.R., Jr., and Braun, Ruth, 1978, A pollution history of Chesapeake Bay: Geochimica et Cosmochimica Acta, v. 42, no. 9, p. 1413-1425.

Gori, P.L., and Burton, W.C., 1996, Debris flow hazards in the Blue Ridge of Virginia: U.S. Geological Survey Fact Sheet FS-96-159, 4 p.

Gray, J.R., 2002, Dirty stories about misleading data, the value and relevance of quality-assured data: Stream Information ExchangeSediment and the Chesapeake Bay Watershed, Conference sponsored by the Maryland Department of Natural Resources and U.S. Fish and Wildlife Service, Linthicum, Maryland.
Gray, J.R., Glysson, J.D., Turcios, L.M., and Schwartz, G.E., 2000, Comparability of suspendedsediment concentration and total suspended solids data: U.S. Geological Survey WaterResources Investigation Report 00-4191, 14 p.

Grover, N.C., 1937, The floods of March 1936, part 3Potomac, James and Upper Ohio Rivers: U.S. Geological Survey Water-Supply Paper 800, $351 \mathrm{p}$.

Guy, H.P., and Ferguson, G.E., 1962, Sedimentation in small reservoirs due to urbanization: Journal of Hydraulics, Division of the American Society of Civil Engineers, no. HY2, Proceedings Paper 3070 , v. 88 , p. $27-37$.

Hack, J.T., 1957, Studies of longitudinal stream profiles in Virginia and Maryland: U.S. Geological Survey Professional Paper 294-B, 97 p.

Halka, J.P., 2000, Deposition and distribution of bottom sediment in the Chesapeake Bay: Maryland Geological Survey Report to the Chesapeake Bay Program, Scientific and Technical Advisory Committee.

Hammer, T.R., 1972, Stream channel enlargement due to urbanization: Water Resources Research, v. 8 , no. 6 , p. $1,530-1,540$.

Hardaway, C.S., Thomas, G.R., Glover, J.B., Smithson, J.B., Berman, M.R., and Kenne, A.R., 1992, Bank erosion study-Special report in applied marine science and ocean engineering: Virginia Institute of Marine Science, School of Marine Science, College of William and Mary, Gloucester Point, Va., no. 319, 79 p.

Harding, L.W., Jr., and Perry, E.S., 1997, Long-term increase of phytoplankton biomass in Chesapeake Bay, 1950-1994: Marine Ecology Progress Series, v. 157, p. 39-52.

Harrison, W.R., Norcross, J.J., Pore, N.A., and Stanley, E.M., 1967, Circulation of shelf waters of the Chesapeake Bight, surface and bottom drift of continental shelf waters between Cape Henlopen, Delaware and Cape Hatteras, North Carolina, June, 1963-December, 1964: ESSA Professional Paper 3, 82 p.

Haven, D.S., Whitcomb, J.P., and Kendall, P.C., 1981, The present and potential productivity of the Baylor grounds in Virginia-Special report in applied marine science and ocean engineering: Virginia Institute of Marine Science, School of Marine Science, College of William and Mary, Gloucester Point, Va., v. 2, no. 243, 89 p.

Helz, G.R., Adelson, J.M., Miller, C.V., Cornwell, J.M., Hill, J.C., Horan, Mary, and Walker, R.J., 2000, Osmium isotopes demonstrate distal transport of contaminated sediments in Chesapeake Bay: Environmental Science and Technology, v. 34 , no. 12 , p. $2,528-2,534$. 


\section{REFERENCES CITED—CONTINUED}

Herman, J.D., 2001, Sediment budgets, estuarine sediment loads, and wetland sediment storage at watershed scales, York River watershed, Virginia: unpublished Ph.D. dissertation Virginia Institute of Marine Science, the College of William and Mary, Gloucester Point, Va., 209 p.

Hill, J.M., Halka, J.P., Conkwright, R., Koczot, K., and Coleman, S., 1992, Distribution and effects of shallow gas on bulk estuarine sediment properties: Continental Shelf Research, v. 12, no. 10, p. 1,219-1,229.

Hill, J.M., Wikel, G., Wells, D.V., Hennessee E.L., and Halka, J.P., 2001, Shoreline erosion as a source of sediments and nutrients: Maryland Geological Survey Report.

Hirschberg, D.J., and Schubel, J.R., 1979, Recent geochemical history of flood deposits in the northern Chesapeake Bay: Estuarine and Coastal Marine Science, v. 9, p. 465-470.

Hobbs, C.H., III, 1983, Organic carbon and sulfur in the sediments of the Virginia Chesapeake Bay: Journal of Sedimentary Petrology, v. 53, p. 383-393.

Hobbs, C.H., III, Halka, J.P., Kerhin R.T., and Carron, M.J., 1990, A 100-year sediment budget for Chesapeake Bay: Special Report in Applied Marine Science and Ocean Engineering, no. 307, Virginia Institute of Marine Science, Gloucester Point, Va., 32 p.

1992, Chesapeake Bay sediment budget: Journal of Coastal Research, v. 8, no. 2, p. 292-300.

Hupp, C.R., 2000, Hydrology, geomorphology, and vegetation of Coastal Plain rivers in the southeastern USA: Hydrological Proceses, v. 14, p. 2,991-3,010.

Hupp, C.R., and Bazemore, D.E., 1993, Temporal and spatial patterns of wetland sedimenta-tion, West Tennessee: Journal of Hydrology, v. 141, p. 179-196.

Hupp, C.R., and Morris, E.E., 1990, A dendrogeomorphic approach to measurement of sedimentation in a forested wetland, Black Swamp, Arkansas: Wetlands, v. 10, p. 107-124.

Hupp, C.R., and Schening, M.R., 1997, Patterns of sedimentation and woody vegetation along black- and brown-water riverine forested wetlands: Association of Southeastern Biologists Bulletin, v. 44, no. 140.

Hupp, C.R., Woodside, M.D., and Yanosky, T.M., 1993, Sediment and trace element trapping in a forested wetland, Chickahominy River, Virginia: Wetlands, v. 13, p. 95-104.
Ibison, N.A., Baumer, J.C., Hill, C.L., Burger, N.H., and Frye, J.E., 1992, Eroding bank nutrient verification study for the Lower Chesapeake Bay: Virginia Department of Conservation and Recreation, Gloucester Point, Va.

Ibison, N.A., Frye, C.W., Frye, J.E., Hill, C.L., and Burger, N.H., 1990, Sediment and nutrient contributions of selected eroding banks of the Chesapeake Bay Estuarine System: Virginia Department of Conservation and Recreation Technical Report, Gloucester Point, Va.

Jacobs, F.R., and Grant, G.C., 1978, Guidelines for zooplankton sampling in quantitative baseline and monitoring programs: Ecological research series, EPA-600/3-78-026.

Jacobsen, R.B., and Coleman, D.J., 1986, Stratigraphy and recent evolution of Maryland Piedmont floodplains: American Journal of Science, v. 286, p. 617-637.

Jenkins, G.S., and Barron, E.J., 1996, Global climate model and coupled regional climate model simulations over the eastern United StatesGENESIS and RegCM2 simulations: Global and Planetary Charge, v. 15, p. 3-32.

Johnson, L.B., 1990, Analyzing spatial and temporal phenomena using geographic information systems: Landscape Ecology, v. 4, no. 1, p. 3143.

Johnston, C.A., 1991, Sediment and nutrient retention by freshwater wetlands-Effects on surface water quality: CRC Critical Reviews in Environmental Control, v. 21, p. 491-565.

Karlsen, A.W., Cronin, T.M., Ishman, S.E., Willard, D.A., Holmes, C.W., Marot, Marci, and Kerhin, R.T., 2000, Historical trends in Chesapeake Bay dissolved oxygen based on benthic foraminifera from sediment cores: Estuaries, v. 23, p. 488-508.

Kearney, M., 1996, Sea-level change during the last 1000 years in the Chesapeake: Journal of Coastal Research, v. 12, p. 977-983.

Kearney, M.S, and Ward, L., 1986, Accretion rates in brackish marshes of a Chesapeake Bay estuarine tributary: Geo Marine Letters, v. 6, p. 41-49.

Kemp, W.M., and Boynton, W.R., 1984, Spatial and temporal coupling of nutrient inputs to estuarine primary production-The role of particulate transport and decomposition: Bulletin of Marine Science, v. 35, p. 522-535.

Kerhin, R.T., Halka, J.P., Hennessee, P.J., Blakeslee, P.J., Wells, D.V., Zoltan, N., and Cuthbertson, R.H., 1983, Physical characteristics and sediment budget for bottom sediments in the Maryland portion of Chesapeake Bay: Unpublished report to the U.S. Environmental Protection Agency. 


\section{REFERENCES CITED-CONTINUED}

Kerhin, R.T., Halka, J.P., Wells, D.V., Hennessee, E.L., Blakeslee, P.J., Zoltan, N., and Cuthbertson, R.H., 1988, The surficial sediments of Chesapeake Bay, Maryland-Physical characteristics and sediment budget: Report of Investigations no. 48., Department of Natural Resources, Maryland Geological Survey, 82 p.

Kerhin, R.T., Williams, Christopher, and Cronin, T.M., 1998, Lithologic descriptions of piston cores from Chesapeake Bay, Maryland: U.S. Geological Survey Open-File Report 98-787, $141 \mathrm{p}$.

Khan, H., and Brush, G.S., 1994, Nutrient and metal accumulations in freshwater tidal marsh: Estuaries, v. 17, p. 345-360.

Kleiss, B.A., 1993, Cache River, Arkansas-Studying a bottomland hardwood (BLH) wetland ecosystem, U.S. Army Waterways Experiment Station, Vicksburg, Mississippi, USA: The Wetlands Research Program, v. 3, no. 1.

1996, Sediment retention in a bottomland hardwood wetland in eastern Arkansas: Wetlands, v. 16, no. 3, p. 321-333.

Knebel, H.J., Martin, E.A., Glenn, J.L., and Needell, S.W., 1981, Sedimentary framework of the Potomac River estuary, Maryland: Bulletin of the Geological Society of America, v. 92, no. 8, p. 578-589.

Kolberg, F.J., and Howard, A.D., 1995, Active channel geometry and discharge relations of U.S. Piedmont and Midwestern streams-The variable exponent model revisited: Water Resources Research, v. 31, no. 9, p. 2,353-2,365.

Kranck, K., Petticrew, E., Milligan, T.G., and Droppo, I.G., 1993, In situ particle size distributions resulting from flocculation of suspended sediment, in Nearshore and estuarine sediment transport coastal and estuarine studies: American Geophysical Union, Washington, D.C., p. 60-74.

Lane, E.W., 1955, The importance of fluvial morphology in hydraulic engineering: American Society of Civil Engineering Proceedings, v. 81, no. 95, p. 1-17.

Langland, M.J., Blomquist, J.D., Sprague, L.A., and Edwards, R.E., 1999, Trends and status of flow, nutrients, and sediments for selected nontidal sites in the Chesapeake Bay Watershed, 19851998: U.S. Gelogical Survey Open-File Report 99-451, 46 p.
Langland, M.J., and Hainly, R.A., 1997, Changes in bottom-surface elevations in the three reservoirs on the Lower Susquehanna River, Pennsylvania and Maryland, following the January 1996 flood-Implications for nutrient and sediment loads to the Chesapeake Bay: U.S. Geological Survey Water-Resources Investigation Report 97-4138, 34 p.

Langland, M.J., Lietman, P.L., and Hoffman, S., 1995, Synthesis of nutrient and sediment data for watersheds within the Chesapeake Bay drainage basin: U.S. Geological Survey WaterResources Investigations Report 95-4233, 121 p.

Leopold, L.B., 1973, River change with time-An example: Geological Society of America Bulletin, v. 84, p. 1845-1860.

Leopold, L.B., Emmett, W.W., and Myrick, R.M., 1966, Channel and hillslope processes in a semiarid area, New Mexico: U.S. Geological Survey Professional Paper, no. 352-G.

Leopold, L.B., and Maddock, T., 1953, The hydraulic geometry of stream channels and some physiographic implications: U.S. Geological Survey Professional Paper 252, 57 p.

Leopold, L.B., Wolman, M.G., and Miller, J.P., 1964, Fluvial processes in geomorphology: San Francisco, W.H. Freeman Publishers, 522 p.

Levine, D.A., Hunsaker, C.T., Timmins, S.P., and Beauchamp, J.J., 1993, A geographic information system approach to modeling nutrient transport and sediment transport: Environmental Science Divison, Oak Ridge National Laboratory, no. 3993, 160 p.

Lin, W., Sanford, L.P., Alleva, B., and Schwab, D., 1997, Surface wind wave modeling in Chesapeake Bay, Ocean wave measurement and analysis: American Society of Civil Engineers, Virginia Beach, Va., p. 1,048-1,062.

Lin, Weigi, Sanford, L.P., and Suttles, S.E., 2002, Wave measurement and modeling in Chesapeake Bay: Continental Shelf Research, v. 22, no. $18-19$, p. $2,673-2,686$.

Lin, J., and Kuo, A., 2001, Secondary turbidity maximum in a partially mixed microtidal estuary: Estuaries, v. 24, no. 5, p. 707-720.

Linker, L.C., and Shenk, G.W., 2000, Cross-media models of the Chesapeake Bay Watershed and airshed: Water Quality and Ecosystem Modeling, v. 1, no. 1-4, p. 91-122.

Ludwick, J.C., 1975, Tidal currents, sediment transport, and sand banks in Chesapeake Bay entrance, Virginia, in Cronin, L.E., ed., Estuarine Research: New York, Academic Press, p. 365-380. 


\section{REFERENCES CITED—CONTINUED}

Lukin, C.G., 1983, Evaluation of sediment sources and sinks-A sediment budget for the Rappahannock River estuary: unpub. MS thesis, School of Marine Science, College of William and Mary.

Mallonee, J.D., Pizzuto, J.E., and Reed, J.M., 2002, Using bucket samples to calibrate the Wilcock two-fraction bed load equation in a MidAtlantic Piedmont stream: American Geophysical Union, Fall Meeting, December 2002, San Francisco, CA.

Marcus, W.A., and Kearney, M.S., 1989, Sediment sources, storage, and flux rates in the upper South River estuary, Maryland: Final report to the Maryland Water Resources Research program of the U.S. Geological Survey, College Park, Maryland, 4 p.

1991, Upland and coastal sediment sources in a Chesapeake Bay estuary: Annals of the Association of American Geographers, v. 81, no. 3, p. 408-424.

Marcus, W.A., Nielsen, C.C., and Cornwell, J.C., 1993, Sediment budget-based estimates of trace metal inputs to a Chesapeake estuary: Environmental Geology, v. 22, p. 1-9.

McCandless, T., and Everett, R., 2002, Bankfull discharge and channel characteristics of the Piedmont hydrologic region: Prepared by the U.S. Fish and Wildlife Service, Annapolis Field Office, CBFO-S02-01.

McCoy, J., Dobson, M.G., and Bowen, S.E., 1997, The evaluation of nutrient loading rates and sediment transport rates prior to the restoration of White Marsh Run: Watershed Restoration Division, Maryland Department of Natural Resources.

Meade, R.H., 1969, Landward transport of bottom sediments in estuaries of the Atlantic Coastal Plain: Journal of Sedimentary Petrology, v. 39, no. 1, p. 222-234.

1972, Sources and sinks of suspended matter on continental shelves, in Swift, D.J.P., Duane, D.B., and Pilkey, O.H., eds., Shelf and sediment transport-Process and pattern: Stroudsburg, Pa., Dowden, Hutchinson, \& Ross, p. 249-262.

Meade, R.H., and Parker, R.S., 1985, Sediment in rivers of the United States, in National Water Summary 1984: U.S. Geological Survey WaterSupply Paper 2275, p. 49-60.

Meade, R.H., Yuzyk, T.R., and Day, T.J., 1990, Movement and storage of sediment in rivers of the United States and Canada, in Wolman, M.G., and Riggs, H.C., eds., The geology of North America: Boulder, Colo., Geological Society of America, v. O-1, p. 255-280.
Middleton, G.V., and Wilcock, P.R., 1994, Mechanics in the earth and environmental sciences: New York, Cambridge University Press, 459 p.

Miller, A.J., 1983, Shore erosion processes, rates, and sediment contributions to the Potomac Tidal River and Estuary: unpub. Ph.D. dissertation, The Johns Hopkins University, 341 p.

1987, Shore erosion as a sediment source to the tidal Potomac River, Maryland and Virginia: U.S. Geological Survey Water-Supply Paper 2234-E, 45 p.

Miller, A.J., Boulton, E., and Huppman, L.R., 2000, Five decades of channel change in an urbanizing watershed: Proceedings of the Spring 2000 American Geophysical Union, Washington, D.C.

Najjar, R.G., 1999, The water balance of the Susquehanna River Basin and its response to climate change: Journal of Hydrology, v. 219, p. 7-19.

Nakagawa, Y., Sanford, L., and Halka, J., 2000, Effect of wind waves on distribution of muddy bottom sediments in Baltimore Harbor, USA, in Edge, B.L., ed., $27^{\text {th }}$ International Conference on Coastal Engineering: Sydney, Australia.

Natural Resources Conservation Service, 1983, National Engineering Handbook- Section 3 Sedimentation, U.S. Department of Agriculture.

2000, National Resources Inventory, 1992: U.S. Department of Agriculture, accessed on November 15, 2000, at URL http://www.nhq.nrcs.usda.gov/NRI

Nichols, M.M., 1974, Development of the turbidity maximum in the Rappahannock Estuary: Memoires de l'Institute de Geologie du Bassin d'Aquitaine, v. 7, p. 19-25.

1977, Response and recovery of an estuary following a river flood: Journal of Sedimentary Petrology, v. 47, no. 3, p. 1,171-1,186, 1,404$1,406$.

Nichols, M.M., Kim, S.C., and Brouwer, C.M., 1991, Sediment characterization of the Chesapeake Bay and its tributaries, Virginian Province: National Estuarine Inventory Supplement, NOAA Strategic Assessment Branch, 88 p.

Novotny, V., and Chesters, G., 1989, Delivery of sediment and pollutants from nonpoint sources-A water quality perspective: Journal of Soil and Water Conservation, v. 44, no. 6 , p. 568-576.

Ocean Surveys, Inc., 1997, Sedimentation surveysTridelphia, Rocky Gorge, and Little Seneca Reservoirs, Howard and Montgomery Counties: Prepared for Washington Suburban Sanitary Commission. 


\section{REFERENCES CITED-CONTINUED}

Officer, C.B., Lynch, D.R., Setlock, G.H., and Helz, G.R., 1984, Recent sedimentation rates in Chesapeake Bay, in Kennedy, V.S., ed., The estuary as a filter: New York, Academic Press, p. 131-157.

Officer, C.B., and Nichols, M.M., 1980, Box model application to a study of suspended sediment distributions and fluxes in partially mixed estuaries, in Kennedy, V.S., ed., Estuarine perspectives: New York, Academic Press, p. 329-340.

Orth, R.J., and Moore, K.A., 1983, Chesapeake BayAn unprecedented decline in submerged aquatic vegetation: Science, v. 222, p. 51-53.

Ortt, R.A., Kerhin, R.T., Wells, D., and Cornwell, J., 2000, Bathymetric survey and sedimentation analysis of Loch Raven and Prettyboy Reservoirs: Maryland Geological Survey, Coastal and Estuarine Geology File Report No. 99-4.

Osterkamp, W.R., Heilman, P., and Lane, L.J., 1998, Economic considerations of a continental sediment monitoring program: Inter-national Journal of Sediment Research, v. 13, no. 4, p. $12-24$.

Pasternack, G.B., and Brush, G.S., 2001, Sedimentation cycles in a river-mouth tidal freshwater marsh: Estuaries, v. 21, no. 3, p. 407-415.

Peltier, W.R., 1996, Global sea level rise and glacial isostatic adjustment-An analysis of data from the east coast of North America: Geophysical Research Letters, v. 23, p. 717-720.

Phillips, J.D., 1991a, Fluvial sediment delivery to a Coastal Plain estuary in the Atlantic Drainage of the United States: Marine Geology, v. 98, p. 121-134.

1991b, Fluvial sediment budgets in the North Carolina Piedmont: Geomorphology, v. 4, p. 231-241.

1995, Decoupling of sediment sources in large river basins, in Osterkamp, W.R., Effects of scale on interpretation and management of sediment and water quality: AHS Publication no. 226, p. 11-16.

Phillips, J.D., Slattery, M.C., and Gares, P.A., 1999, Truncation and accretion of soil profiles on coastal plain croplands-Implications for sediment redistribution: Geomorphology, v. 28 , p. $119-140$.

Pierce, J., and Dulong, F., 1977, Discharge of suspended particulates from Rhode River subwatersheds, in Correll, D.L., ed., Watershed Research in Eastern North

America: Edgewater, Md., Chesapeake Bay Center for Environmental Studies, Smithsonian Institution.
Pizzuto, J.E., 1992, The morphology of graded gravel rivers-A network perspective: Geomorphology, v. 5, p. 457-474.

Pizzuto, J.E., Hession, W.C., and McBride, M., 2000, Comparing gravel bed rivers in paired urban and rural catchments of southeastern Pennsylvania: Geology, v. 28, no. 1, p. 79-82.

Prestegaard, K., Dusterhoff, S., Stoner, C.E., Houghton, K., Folk, K., and Smith, B., 2000, Morphological and hydrological characteristics of Piedmont and Coastal Plain streams in Maryland: Prepared by the Department of Geology, University of Maryland for the Maryland Department of the Environment.

Preston, S.D., and Brakebill, J.W., 1999, Application of spatially referenced regression modeling for the evaluation of total nitrogen loading in the Chesapeake Bay watershed: U.S. Geological Survey Water Resources Investigations Report 99-4054, 12 p.

Reed, L.A., and Hainly, R.A., 1989, Suspendedsediment yields from an unmined area and from mined areas before and after reclamation in Pennsylvania, June 1978-September 1983: U.S. Geological Survey Water-Resources Investigations Report 88-4005, 50 p.

Richards, K.S., and Lane, S.N., 1997, Prediction of morphological cahanges in unstabe channels in Thorne, C.R., Hey, R.D., and Newson, M.D., Applied fluvial geomorphology for review enginerring and management: New York, John Wiley and Sons, Inc.

Roberts, W.P., and Pierce, J.W., 1974, Sediment yield in the Patuxent River (Maryland) undergoing urbanization, 1968-1969: Sedimentary Geology, v. 12 , no. 3 , p. $179-197$. 1976, Deposition in Upper Patuxent Estuary, Maryland, 1968-1969: Estuarine and Coastal Marine Science, v. 4, no. 3, p. 267-280.

Robertson, D.M., and Roerish, E.D., 1999, Influence of various water quality sampling strategies on load estimates for small streams: Water Resources Research, v. 35, no. 12, p. 3,747-3,759.

Robinson, A.M., 1976, The effects of urbanization on stream channel morphology: National Symposium on Urban Hydrology, Hydraulics, and Sediment Control, p. 115-127.

Ryan, J.D., 1953, The sediments of Chesapeake Bay: Maryland Department of Geology, Mines and Water Resources Bulletin 12, 120 p.

Sanford, L.P., 1994, Wave-forced resuspension of upper Chesapeake Bay muds: Estuaries, v. 17, no. 1B, p. 148-165. 


\section{REFERENCES CITED-CONTINUED}

Sanford, L.P., and Halka, J.P., 1993, Assessing the paradigm of mutually exclusive erosion and deposition of mud, with examples from upper Chesapeake Bay: Marine Geology, v. 114, p. 3757.

Sanford, L.P., Panageotou, W., and Halka, J.P., 1991, Tidal resuspension of sediments in northern Chesapeake Bay: Marine Geology, v. 97, p. 87103.

Sanford, L.P., Suttles, S.E., and Halka, J.P., 2001, Reconsidering the physics of the Chesapeake Bay Estuarine Turbidity Maximum: Estuaries, v. 24, no. 5, p. 655-669.

Scatena, F.N., 1987, Sediment budgets and delivery in a suburban watershed: unpub. Ph.D. dissertation, The Johns Hopkins University.

Schening, M.R., Hupp, C.R., and Herbst, A.R., 1999, Sediment transport and storage in forested wetlands along the Chesapeake Bay tributaries: Bulletin of the Society of Wetland Scientists, v. 16, no. 40.

Schubel, J.R., 1968a, Suspended sediment of the Northern Chesapeake Bay: Johns Hopkins University, Chesapeake Bay Institute, $35 \mathrm{p}$. 1968b, Turbidity maximum of the Northern Chesapeake Bay: Science, v. 161, p. 1,013-1,015.

1969, Distribution and transportation of suspended sediment in Upper Chesapeake Bay: Baltimore, Md., Chesapeake Bay Institute, Johns Hopkins University, 29 p.

1971, Tidal variation of the size distribution of suspended sediment at a station in the Chesapeake Bay turbidity maximum: Netherlands Journal of Sea Research, v. 5, no. 2, p. 252-266.

Schubel, J.R., and Biggs, R.B., 1969, Distribution of Seston in Upper Chesapeake Bay: Chesapeake Science, v. 10, no. 1, p. 18-23.

Schubel, J.R., and Carter, H.H., 1976, Suspended sediment budget for Chesapeake Bay, in Wiley, M.L., ed., Estuarine Proesses: New York, Academic Press, p. 46-62.

Schubel, J.R., and Kana, T.W., 1972, Agglomeration of fine-grained suspended sediment in Northern Chesapeake Bay: Powder Technology, v. 6, p. 9-16.

Schubel, J.R. and D.W. Pritchard, 1986, Responses of upper Chesapeake Bay to variations in discharge of the Susquehanna River: Estuaries v. 9, no. 4 A, p. 236-249.

Schueler, T., and Lugbill, J., 1990, Performance of current sediment control measures at Maryland construction sites: Washington, D.C., Metropolitan Washington Council of Goverments, $90 \mathrm{p}$.
Schumm, S., 1977, The fluvial system: New York, John Wiley and Sons, Inc., 338 p.

Schwarz, G.E., and Alexander, R.B., 1995, State Soil Geographic (STATSGO) Data Base for the Conterminous United States: U.S. Geolo-gical Survey Open-File Report 95-449.

Shanholtz, V. O., 1988, Delivery ratio for targeting; unpublished manuscript, $18 \mathrm{p}$.

Simon, A., 1989, A model of channel response in disturbed alluvial channels, Earth Surface Processes and Landforms, v. 14, no. 1, p. 11-26.

Singewald, J.T., Jr., 1911, Reports on the iron ores of Maryland with an account of the iron industry: Maryland Geological Survey Reports, v. 9, pt. 3, p. 336.

Singewald, J.T., and Slaughter, T.H., 1949, Shore erosion in tidewater Maryland: Maryland Department of Geology, Mines and Water Resources, Bulletin no. 6, 51 p.

Smith, R.A., Schwarz, G.E., and Alexander, R.B., 1997, Regional interpretation of water-quality monitoring data: Water Resources Research, v. 33 , no. 12 , p. 2,781-2,798.

Smith, S., 1997, Changes in the hydraulic and morphological characteristics of a relocated stream channel. Masters Thesis, Department of Geology, University of Maryland.

Smith, S., Bereciartua, P., Johnson, P., and Haltiner, J., 1999, Channel design and the forgotten floodplain, Proceedings: International Water Resource Engineering Conference: American Society of Civil Engineers.

Smith, S., Gutierrez, 1., and Gagnon, A., 2000, Streams of Maryland, take a closer look: Watershed Restoration Division-Maryland Department of Natural Resources.

Stallard, R.F., 1998, Terrestrial sedimentation and the carbon cycle: Global Biogeochemical Cycles, v. 12, no. 2, p. 231-257.

Steffen, L.J., 1996, A reservoir sedimentation survey information system-RESIS, in Proceedings of the Sixth Federal Interagency Sedimentation Conference, March 10-14, 1996, Las Vegas, Nev.: Sponsored by the Subcommittee on Sedimentation Interagency Advisory Committee on Water Data, p. 29-37.

Stevenson, J., Ward, L., and Kearney, M., 1988, Sediment transport and trapping in marsh system-Implications of tidal flux studies: Marine Geology, v. 80, p. 37-59. 


\section{REFERENCES CITED-CONTINUED}

Stevenson, J.C., Ward, L.G., Kearney, M.S., and Jordan, T.E., 1985, Sedimentary processes and sea level rise in tidal marsh systems of the Chesapeake Bay, in Meyer, E., ed., Wetlands of the Chesapeake-Protecting the future of the Bay: Environmental Law Institute, Washington, D.C., p. 37-62.

Stumpf, R.P., 1988, Sediment transport in Chesapeake Bay during floods-Analysis using satellite and surface observations: Journal of Coastal Research, v. 4, no. 1, p. 1-15.

Susquehanna River Basin Commission, 2000, Proceedings from sediment symposium, Hershey, Pa., December 7-8, 2000: Susquehanna River Basin Commission Publication No. 216E.

Swanson, F.J., Janda, R.J., Dunne, T., and Swanston, D.N., 1982, Sediment budgets and routing in forested drainage basins: U.S. Department of Agriculture, Forest Service General Technical Report PNW-141, p. 23.

Titus, J.G., and Richman, C., 2001, Maps of lands vulnerable to sea level rise-Modeled elevations along the U.S. Atlantic and Gulf coasts: Climate Research, v. 18, p. 205-228.

Trimble, S.W., 1981, Changes in sediment storage in the Coon Creek Basin, Driftless Area, Wisconsin, 1853 to 1975 : Science, v. 214, p. 181183.

1997, Contribution of stream channel erosion to sediment yield from an urbanizing watershed: Science, v. 278, p. 1,442-1,444.

1999, Decreased rates of alluvial sediment storage in the Coon Creek Basin, Wisconsin, 1975-83: Science, v. 285, p. 1,244-1,246.

Trimble, S.W., and Crosson, Pierre, 2000, U.S. soil erosion rates-Myth and reality: Science, v. 289 , p. $248-250$.

U.S. Army Corps of Engineers, 1977, Chesapeake Bay future conditions report, Volume 1 , Summary: Baltimore, Maryland, 125 p.

1990, Chesapeake Bay Shoreline Erosion StudyBaltimore, Md., Department of the Army, U.S. Army Corps of Engineers, 111 p.

1996, National Inventory of Dams, accessed November 13, 2000, at URL http://crunch.tec.army.mil

U.S. Environmental Protection Agency, 1993, Guidance for spedifying management measures for nonpoint pollution in coastal waters: EPA 840-B-92-002, 740 p.

2000a, National water quality inventory, 1998 report to Congress, accessed September 15, 2000, at URL http://www.epa.gov/305b/98report 2000b, The quality of our nation's water, 1998: EPA841-S-00-001, accessed September 27, 2000, at URL http://www.epa.gov/305b/ 98report/98brochure.pdf

U.S. General Accounting Office, 1990, Water pollution - Greater EPA leadership needed to reduce non-point source pollution: U.S. General Accounting Office Report GAO/RCED-91-10, $56 \mathrm{p}$.

U.S. Geological Survey, 2000, Hydro 1k elevation derivative database, accessed November 13, 2000, at URL http://edcdaac.usgs.gov/gtopo30/ hydro/namerica.html

Vanoni, V.A., 1975, Sedimentation engineering, Prepared by the ASCE Task Committee for the Preparation of the Manual on Sedimentation of the Sedimentation Committee of the Hydraulics Division: American Society of Civil Engineers, New York, New York.

VirGIS, Agricultural Pollution Potential Database Reports for Soil and Water Conservation Districts, Dept. of Conservation and Recreation: Virginia Division of Soil and Water Conservation, Richmond, Virginia.

Colonial SWCD, 1988.

Culpeper SWCD, 1988.

Hanover-Caroline (Caroline County) SWCD, 1988.

Hanover-Caroline (Hanover County) SWCD, 1988.

Monacan SWCD, 1988.

Thomas Jefferson SWCD, 1989.

Thomas Jefferson (Albemarle County) SWCD, 1990.

Three Rivers (Essex County) SWCD, 1988.

Three Rivers (King and Queen County) SWCD, 1993.

Three Rivers (King William County) SWCD, 1990.

Tidewater SWCD, 1988.

Tri-County/City SWCD, 1988.

Walling, D.E, 1983, The sediment delivery problem: Journal of Hydrology, v. 65, p. 209-237.

1988, Erosion and sediment yield researchSome recent perspectives: Journal of Hydrology, v. 100, p. 113-141.

1994, Measuring sediment yield from river basins, in Lal, R., ed., Soil erosion, Research methods (2nd ed.): Ankeny, Iowa, Soil and Water Conser-vation Society, p. 39-80.

Ward, L.G., 1985, The influence of wind waves and tidal currents on sediment resuspension in Middle Chesapeake Bay: Geo-Marine Letters, v. 5, p. 71-75. 


\section{REFERENCES CITED—CONTINUED}

Werrity, A., 1997, Short term changes in channel stability, in Thorne, C.R., Hey, R.D., and Newson, M.D., eds.: Applied Fluvial Geomorphology for River Engineering and Management: New York, John Wiley and Sons, Inc., p. 47-65.

Wilcock, P.W., 1998, Two-fraction model of initial sediment motion in gravel-bed rivers: Science, v. 280 , p. $410-412$.

2002, Sediment transport readings and notes, Department of Geography and Environ-mental Engineering: The Johns Hopkins University.

Willard, D.A., Cronin, T.M., and Verardo, S., 2003, Late Holocene climate and ecosystem variability from Chesapeake Bay sediment cores: The Holocene, v. 13, p. 201-214.

Williams, K.F., and Reed, L.A., 1972, Appraisal of stream sedimentation in the Susquehanna River basin: U.S. Geological Survey WaterSupply Paper 1532-F, 24 p.

Wohl, E., 2000, Mountain Rivers, Water Resources Monograph 14: American Geophysical Union.

Wolman, M.G., 1954, A method of sampling coarse river-bed material: EOS Transactions, v. 35, p. 951-956.

1977, Changing needs and opportunities in the sediment field: Water Resources Research, v. 13 , no. 1 , p. $50-54$.

1987, Sediment movement and knickpoint behavior in a small Piedmont drainage basin: Geografiska Annaler, v. 69A, no. 1, p. 514.

Wolman, M.G., and Gerson, R., 1978, Relative time scales and effectiveness of climate in watershed geomorphology: Earth Surface Processes, v. 3, p. 189-203.

Wolman, M.G., and Miller J.P., 1960, Magnitude and frequency of forces in geomorphic processes: Journal of Geology, v. 68, p. 54-74.

Wolman, M.G., and Schick, A.P., 1967, Effects of construction on fluvial sediment, urban and surburban areas of Maryland: Water Resources Research, v. 3, no.2, p. 451-464.
Wright, L.D., Boon, J.D., Xu, J.P., and Kim, S.C., 1992, The bottom boundary layer of the Bay Stem Plains environment of lower Chesa-peake Bay: Estuarine, Coastal and Shelf Science, v. 35, p. 17-36.

Yarbro, L.A., Carlson, P.R., Crump, R.J., Chanton, R.J., Fisher, T.R., Burger, N., and Kemp, W.M., 1981, Seston dynamics and a seston budget for the Choptank River Estuary in Maryland: University of Maryland, Horn Point Environmental Laboratories, UMCEES Reference No. 81-252.

Yarbro, L.A., Carlson, P.R., Fisher, T.R., Chanton, J.P., and Kemp, W.M., 1983, A sediment budget for the Choptank River estuary in Maryland, U.S.A.: Estuarine, Coastal and Shelf Science, v. 17 , p. 555-570.

Yorke, T.H., and Herb, W.J., 1978, Effects of urbanization on streamflow and sediment transport in the Rock Creek and Anacostia River Basins, Montgomery County, Mary-land, 1962-74: U.S. Geological Survey Professional Paper 1003, $71 \mathrm{p}$.

Zabawa, C.F., 1978, Microstructure of agglo-merated suspended sediments in northern Chesapeake Bay Estuary: Science, v. 202, no. 4363, p. 4951.

Zabawa, C.F., and Ostrom, C., 1980, The role of boat wakes in shore erosion in Anne Arundel County, Maryland: Annapolis, Maryland Department of Natural Resources, Tidewater Administration, $210 \mathrm{p}$.

Zaneveld, J.R.V., Spinrad, R.W., and Bartz, R., 1979, Optical properties of turbidity standards: Spie, v. 208, p. 159-168.

Zimmerman, A.R., and Canuel, E.A., 2000, A geochemical record of eutrophication and anoxia in Chesapeake Bay sediments, anthropogenic influence on organic matter composition: Marine Chemistry, v. 69, p. 117137.

Zynjuk, L.D., and Majedi, B.F., 1996, January 1996 floods deliver large loads of nutrients and sediment to the Chesapeake Bay: U.S. Geological Survey Fact Sheet FS-96-140, 2 p. 
